\author{
UNIVERSIDADE DE SÃO PAULO \\ ESCOLA DE COMUNICAÇÕES E ARTES
}

ELIZA BACHEGA CASADEI

\title{
JORNALISMO E RESSIGNIFICAÇÃO DO PASSADO: OS FATOS HISTÓRICOS NAS NOTÍCIAS DE HOJE
}

Dissertação apresentada ao Programa de Pós-Graduação em Ciências da Comunicação, Área de Concentração I: Teoria e Pesquisa em Comunicação, inserido na Linha de Pesquisa Linguagem e Produção de Sentido, da Escola de Comunicações e Artes da Universidade de São Paulo, como exigência parcial para a obtenção do Título de Mestre em Ciências da Comunicação, sob a orientação da Prof $^{a} \operatorname{Dr}^{a}$ Mayra Rodrigues Gomes. 


\section{JORNALISMO E RESSIGNIFICAÇÃO DO PASSADO: OS FATOS HISTÓRICOS NAS NOTÍCIAS DE HOJE}

Dissertação apresentada ao Programa de Pós-Graduação em Ciências da Comunicação, Área de Concentração I: Teoria e Pesquisa em Comunicação, inserido na Linha de Pesquisa Linguagem e Produção de Sentido, da Escola de Comunicações e Artes da Universidade de São Paulo, como exigência parcial para a obtenção do Título de Mestre em Ciências da Comunicação, sob a orientação da Prof $^{a} \operatorname{Dr}^{\mathrm{a}}$ Mayra Rodrigues Gomes.

\section{SÃo PAULO}


A dissertação de mestrado Jornalismo e Ressignificação do Passado: os fatos históricos nas notícias de hoje, realizada pela aluna Eliza Bachega Casadei sob a orientação da Prof ${ }^{a} \operatorname{Dr}^{\mathrm{a}}$ Mayra Rodrigues Gomes, foi aprovada, no dia ___________ pela banca composta pelos professores doutores:

Mayra Rodrigues Gomes (orientadora)

Rosana de Lima Soares (ECA-USP)

Sandra Lúcia Amaral de Assis Reimão (EACH-USP) 


\title{
RESUMO
}

A veiculação de dados históricos pela imprensa é uma das responsáveis por nossa percepção do passado, como herança, e do presente, como seu efeito. Esta pesquisa propõe o estudo das formas a partir das quais o recurso à história se constitui como uma estratégia de semantização do evento jornalístico, com as regras e as complexidades inerentes às práticas midiáticas. Para isso, investigaremos, de um lado, como o passado circunscreve os eventos do presente relatados pelas narrativas jornalísticas dentro de um conjunto de significados já estabelecidos; e, de outro, como é o próprio acontecimento jornalístico já semantizado que constrói o passado e o futuro que servirão de guia para o entendimento do relatado, erguendo, assim, determinados quadros de significação. Utilizaremos os aportes teóricos e metodológicos da Análise da Narrativa e da Análise do Discurso (através dos conceitos operatórios dos "pressupostos" e "subentendidos", de Oswald Ducrot). E a partir disso, estudaremos, portanto, a forma pela qual, ao evocar a História, o jornalismo invoca a edificação de lugares de sentido.

Palavras-chave: comunicação - jornalismo - história - memória - revistas semanais semantização - narrativa - discurso.

\begin{abstract}
The transmission of historical data for the press is one of those responsible for our perception of the past, such as inheritance, and the present, as its effect. This research proposes the study of forms from which history is viewed as a semantization strategy for journalistic event, from the rules and complexity of midiatic pratices. For this, we will investigate, on one hand, how the past fits the reported events in journalistic narratives inside a set of meanings that are already established; and, on the other hand, how the semanticised journalistic event itself construct the past and future that will serve as a guide for the understanding of the reported, raising, thus, certain frames of meaning. To achieve this objective, we will use the theoretical and methodological tools of the Narrative Analysis and Discourse Analysis (through the operational concepts of "assumptions" and "implied" by Oswald Ducrot). And from this, we study how, in the evocation of history, journalism invokes the building of meaning places.
\end{abstract}

Keywords: communication - journalism - history - memory - semantization magazines - narrative - discourse. 


\section{AGRADECIMENTOS}

Muitos autores utilizam a metáfora do tecido para descrever o que é um texto. Isso porque, da mesma forma que um pano, uma produção textual também seria formada por linhas (de intertextualidade) que se entrecruzam, formando um todo. Tratase de uma metáfora que também ajuda a lembrar que um texto nunca é fruto de um esforço meramente individual. E são muitas as linhas e as vozes que se entrecruzam neste trabalho e que merecem um reconhecimento sincero da minha gratidão.

Primeiramente gostaria de agradecer aos meus pais, Eduardo e Lúcia Mercy, por todo apoio, amor e esforço conjunto que tornaram este trabalho possível. Também agradeço à minha irmã Amanda pela amizade e camaradagem. E também ao Rafael, pelo suporte, companheirismo e pela alegria que me traz todos os dias. Vocês são os amores da minha vida e talvez não haja palavras para expressar o quanto eu os admiro e como este trabalho não poderia existir sem vocês.

Também agradeço a minha orientadora, Prof ${ }^{\mathrm{a}}$. Dr ${ }^{\mathrm{a}}$. Mayra Rodrigues Gomes pela generosidade, atenção e olhar rigoroso em todos esses anos em que trabalhamos juntas e também por sempre ter aberto portas e mostrado caminhos.

Agradeço também a Prof ${ }^{\mathrm{a}}$. Dr ${ }^{\mathrm{a}}$. Rosana de Lima Soares e a Prof ${ }^{\mathrm{a}}$. Dr ${ }^{\mathrm{a}}$. Sandra Reimão, pelas sugestões e conselhos valiosos que me deram durante a banca de qualificação.

São tantas as pessoas que eu devo agradecer que não posso deixar de me sentir uma pessoa sortuda. Agradeço o Duarte e a Fátima (pela amizade e por terem me ajudado a transformar meu quarto em uma biblioteca), os meus familiares (pelo ponto de apoio e de sustentação), os meus amigos do MidiAto e do Alterjor (por compartilharem a jornada acadêmica), bem como os professores e funcionários da Escola de Comunicações e Artes da Universidade de São Paulo.

Por fim, agradeço também ao CNPq (Conselho Nacional de Pesquisa e Desenvolvimento) pela bolsa concedida que me permitiu fazer este trabalho com tranquilidade e total imersão.

Sem esses fios todos de sustentação, este texto não existiria. 


\section{SUMÁRIO}

PRELÚDIO - A Semantização do Presente Através da História: as memórias do tempo e as formas de inteligibilidade do mundo

INTRODUÇÃO - Entre a Urdidura de Enredo e os Conteúdos Implícitos: o jogo entre o atual e o decorrido nas revistas semanais.

1. A urdidura de enredo, os pressupostos e os subentendidos: elementos da semantização do fato jornalístico

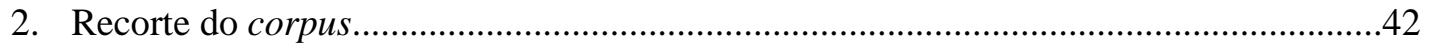

3. Especificidades do cruzamento entre a história e o jornalismo.......................................46

CAPÍTULO I - O Jornalismo e a História como Discursos Referenciais: a vontade de real nas construções imaginárias do mundo.

1. História e Jornalismo como artefatos verbais: a construção de mundos possíveis a partir da sujeição à narrativa.

2. A vontade de real: a ilusão referencial dos discursos jornalísticos e históricos.

3. A História como fala do Outro: o reforço da ilusão referencial jornalística a partir da evocação histórica.

CAPÍTULO II - O Jornalismo e a História: duas construções do tempo, duas construções

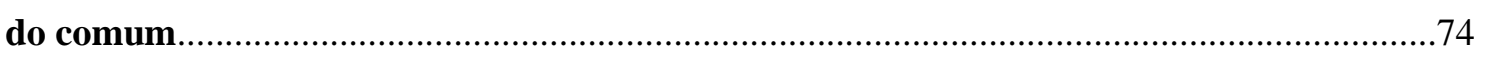

1. A Construção Imaginária do Tempo no Jornalismo.........................................................

2. A Construção Imaginária do Comum no Jornalismo........................................................82

3. O que pode o passado nos dizer acerca do comum, do presente e do futuro?...................86 3.1. A inscrição do presente e do futuro no passado e a relação com as narrativas jornalísticas.

3.2. O passado como um comum: os lugares de memória nos discursos jornalísticos. ..98 
CAPÍTUlO III - Usos da História e Trajetórias Pessoais na Reportagem: a matriz da

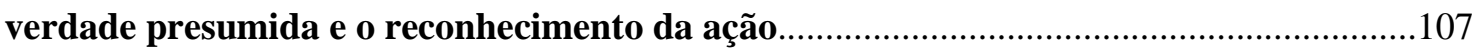

1. O Estatuto do Testemunho no Jornalismo: a matriz de verdade presumida....................112

2. Vinculação "pessoa-ato" como doador de legitimidade para a ação...............................130

2.1. O julgamento do ato a partir da quebra do vínculo metonímico.............................139

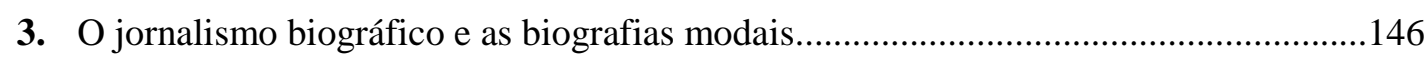

4. Sobre as sequências e funções de trajetórias pessoais e o estatuto do personagem no jornalismo.

CAPÍTUlo IV - Comparações e Disjunções entre o Atual e o Decorrido: as

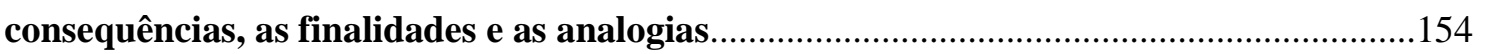

1. O Peso das Consequências: comparação histórica e argumentos pragmáticos..............156

2. O Deliberado e o Involuntário: o jogo entre as finalidades e as consequências nas funções narrativas de ordem comparativa e de disjunção...............................................168

3. Enquadramentos comparativos: alusões históricas como analogia...............................172

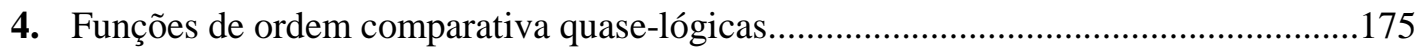

5. As narrativas de disjunção nas editorias de comportamento e de ciência e tecnologia

6. Sobre as relações constitutivas através do outro e as funções e sequências narrativas de ordem comparativa e de disjunção.

CAPÍTUlo V - A Origem e os Pontos Fortes da Narrativa: vinculações de coexistência

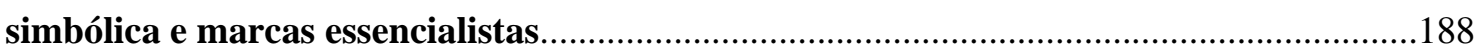

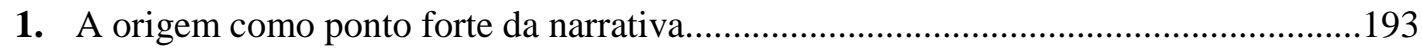

2. As funções e sequências de origem na construção das reportagens................................218

CONSIDERAÇÕES FINAIS - Evocar a História para Invocar Lugares de Sentido: as narrativas jornalísticas e a remissão ao decorrido 


\section{PRELÚDIO}

\section{A SEMANTIZAÇÃO DO PRESENTE ATRAVÉS DA HISTÓRIA: AS MEMÓRIAS DO TEMPO E AS FORMAS DE INTELIGIBILIDADE DO MUNDO}

Em setembro de 1808, um editorial do Correio Braziliense, de Hipólito da Costa, considerado o primeiro jornal brasileiro, definia a tarefa do jornalismo em termos curiosos. Segundo ele, sua missão seria "referir com imparcialidade as memórias do tempo e dar todos os dados possíveis ao leitor para ajuizar das causas dos acontecimentos e, quando couber na alçada humana, preconizar-lhe as consequências" (apud RIBEIRO, 2004: 40).

Essa imagem do jornalista como um guardião do tempo e um armazenador da memória coletiva sobreviveu às épocas e é mesmo uma imagem ocasionalmente referida. Fraser Bond (1959: 324), por exemplo, ao invocar alguns princípios do jornalismo chega a afirmar que "alguns editores possuem o que se chama de mentefichário", ou seja, para além de estarem preocupados apenas com o presente, funcionam como arquivos vivos, transmissores e organizadores que são de uma memória coletiva.

Também Hobsbawm (2005: 20) enfatiza este papel da imprensa ao afirmar que a organização da memória coletiva, quando vista a partir da ótica da cotidianidade, não pode ser encarada como uma espécie de tradição ancestral. Ela está mais ligada ao que as pessoas aprenderam sobre a história a partir de figuras como padres, professores, autores de livros de história, jornalistas e organizadores de programas de televisão.

A problemática aludida por estes autores remete a uma discussão antiga que nasceu conjuntamente com o próprio termo "memória coletiva". Logo após o lançamento do livro Les Cadres Sociaux de la Memoire, (obra-prima de Maurice Halbwachs que inseriu este termo como um ponto nevrálgico de entendimento para as ciências dos homens), em 1925, o historiador Marc Bloch (1998: 224) publicou uma resenha em que - embora afirmasse que a obra de Halbwachs era extremamente rica e sugestiva - apresentava uma série de críticas ao livro que, de certa forma, marcam um ponto de partida sobre as depurações que teóricos posteriores dariam em torno desta temática. Para Bloch, o problema do livro estava em ignorar a questão primordial da transmissão destes elementos que nos são legados do passado. Em outras palavras, estava em não considerar a temática da memória coletiva como uma problemática comunicacional.

Pelo menos uma parte dos fenômenos que são chamados de memória coletiva, para este autor, é, na verdade, "fatos da comunicação entre indivíduos". Isso porque 
“para que um grupo social cuja duração ultrapassa uma vida humana se 'lembre' não basta que os diversos membros que o compõem em um dado momento conservem no espírito as representações que dizem respeito ao passado do grupo". Antes de qualquer coisa, "é também necessário que os membros mais velhos cuidem de transmitir essas representações aos mais jovens" (BLOCH, 1998: 229).

Ao tratar a questão da memória coletiva como um dado comunicacional, várias implicações são articuladas a partir da noção de que os mesmos problemas que afligem a comunicação atingem também a memória coletiva. E isso diz respeito, basicamente, ao fato de que ela está sujeita a derrapagens de sentido, a erros de transmissão, a mal entendidos e até mesmo, a distorções conscientes em torno do passado. Bloch coloca, portanto, a possibilidade de existirem falsas recordações e enganos dentro da memória coletiva. Ele cita como exemplo o fato de que "essencialmente tradicionalistas, as sociedades da Idade Média sonharam reviver a sua memória; mas esta memória não foi, em muitos aspectos, mais que um espelho infiel" (BLOCH, 1998: 231).

É também neste sentido que Todorov (2002) chama a atenção para o fato de que o trabalho da memória se estrutura em torno de duas premissas principais que são a fidelidade para com o passado e a utilidade para o presente. A imagem renascentista que ele descreve sobre uma mulher de dois rostos (cada um deles voltado para um lado da cadeia temporal) que carrega em uma das mãos um livro - para buscar informações sobre o passado - e na outra, um lápis - para escrever sobre o presente - evoca o fato de que há sempre um mediador entre o passado e o presente: estão postos, entre essas duas temporalidades, sempre um narrador e uma narrativa.

Por se tratar de uma questão comunicacional, portanto, a transmissão do passado ligada à memória coletiva e à história também diz respeito, obviamente, a uma problemática de linguagem, estando relacionada, mesmo à forma como os homens imprimem sentido ao mundo. Trata-se de um problema que não pode ser separado dos processos de semantização dos acontecimentos. E, neste campo, isso significa adotar uma lógica circular a partir da qual o passado é tomado como um guia para o presente ao mesmo tempo em que é este próprio presente quem o atualiza e constrói.

Vários autores trabalham em torno desta questão.

Para Ricoeur (2007: 242), por exemplo, a representação do passado possibilitada pelas narrativas coloca o decorrido sob os olhos, na medida em que, por um lado, evoca uma coisa ausente "por meio de uma coisa substituída que é o seu representante padrão" e, por outro, exibe uma presença oferecida aos olhos, "a visibilidade da coisa presente 
tendendo a ocultar a operação de substituição que equivale a uma verdadeira substituição do ausente”.

Mais do que "dar a ver" ou "colocar sob os olhos", no entanto, essa narrativa também "dá a entender", em uma operação que engendra o "entrecruzamento da legibilidade e da visibilidade no seio da representação historiadora" (RICOEUR, 2007: 276). Isso porque ao mesmo tempo em que a apresentação do passado se constitui enquanto uma imagem presente de uma coisa ausente (esse "ter sido, apesar de não ser mais" da história que torna o passado próximo ou reconhecível), ela também apresenta, em seu próprio signo, uma série de personagens e instituições que se alocam sob uma teoria. Assim, além de uma função meramente cognitiva (na medida em que cristaliza significados), a representação do passado também possui uma função social, gerando regimes discursivos na inscrição dos sujeitos.

“O uso do nome próprio - Revolução Francesa, 'solução final', etc. - é um dos signos distintivos da lógica circular, em virtude da qual o nome próprio funciona como sujeito lógico para toda uma série dos atributos que o desenvolvem em termos de acontecimentos, estruturas, personagens, instituições". E assim, "essas narratios, como diz Ankersmit, tendem à autoreferencialidade, já que o sentido do nome próprio não é dado fora dessa série de atributos" (RICOEUR, 2007: 291).

As representações do passado lidam, assim, com uma ausência dupla: a primeira, posta pela linguagem, está na ausência das coisas nas palavras, do nomeado nos nomes; a segunda, posta pelo caráter do referente, está na morte do acontecimento, uma vez que ele está posto no passado, na condição de decorrido. "Dupla ausência, portanto, 'a da coisa que não existe mais' e a do acontecimento que 'nunca foi como se disse"" (RICOEUR, 2007: 379).

É também neste sentido que a representação historiadora se caracteriza como a fala de um outro. Ou seja, mais do que "dar a ver" e "dar a entender", a apresentação do passado também "faz falar". Em outras palavras, o "acontecimento e o nome andam juntos na encenação. Quem faz ver, faz falar. (...) O discurso substituído é essencialmente antimimético; ele não existe, produz algo oculto: ele diz o que esses outros poderiam dizer" (RICOEUR, 2007: 356).

Uma vez que os rastros são mudos, esse "falar ainda" do passado é possibilitado pela narrativa da História. Como bem aponta Michelet (apud RICOEUR, 2007: 378), "a escrita historiadora dá lugar à falta, e a esconde; ela cria essas narrativas do passado que são equivalentes aos cemitérios nas cidades; ela exorciza e reconhece uma presença da morte no meio dos vivos". Em outras palavras, "é a função do discurso, como lugar da 
palavra, oferecer aos mortos do passado uma terra e um túmulo" (RICOEUR, 2007: 380).

De acordo com estas premissas, Hayden White (2008: 18) define o labor histórico como, fundamentalmente, "uma estrutura verbal na forma de um discurso narrativo em prosa que pretende ser um modelo, ou ícone, de estruturas e processos passados no interesse de explicar o que eram representando-os".

O trabalho dos diversos profissionais que atuam na transmissão do passado, com seus distintos interesses, seria, neste sentido, efetuar a transformação da crônica (entendida enquanto mero arranjo dos acontecimentos tratados na ordem temporal de sua ocorrência) em estória (através de um (re)arranjo dos eventos nos componentes de um espetáculo ou processo de acontecimento que podem ser ordenados através de eventos iniciais, motivos de transição e motivos conclusivos). Somente quando um determinado conjunto de eventos é organizado de acordo com um código de motivos, podemos dizer que o leitor tem diante de si uma estória. Assim, "a crônica de eventos transforma-se num processo diacrônico concluído, a respeito do qual é possível então fazer perguntas como se estivesse lidando com uma estrutura sincrônica de relações" (WHITE, 2008: 21).

Montar o enredo através de uma narrativa - ou prover de sentido uma estória tem implicações sociais importantes uma vez que diz respeito aos modos com os quais nos relacionamos com o mundo. White (2008: 36) coloca mesmo que "a própria afirmação de se ter distinguido um mundo passado de um mundo presente de reflexão e práxis social, e de se ter determinado a coerência formal daquele mundo passado, implica uma concepção da forma que o conhecimento do mundo presente também deve tomar, na medida em que é contínuo com aquele mundo passado".

Desta forma, o compromisso com uma forma específica de conhecimento histórico corresponde a uma série de predeterminações, circunscrevendo quais são as generalizações que são permitidas de serem feitas acerca do mundo presente e até mesmo quais são os tipos de conhecimentos que se podemos conceber acerca dele. E mais do que isso, como consequência deste processo, predetermina também os tipos de projetos que nos são considerados lícitos de conceber, tanto para mudar o presente quanto para mantê-lo indefinidamente em sua forma vigente.

É neste sentido que Huizinga (apud SETERS, 2008: 19) coloca que a "História é a forma intelectual na qual uma civilização presta contas de seu passado a si própria”. E este acerto pode ser concebido tanto como uma forma de imputar responsabilidades e fazer apreciações sobre os eventos do passado de uma nação (com suas consequências 
para o mundo do presente); quanto pode estar relacionado à identidade coletiva de um povo ${ }^{1}$.

Se pudéssemos resumir a questão destes autores, apontaríamos para o fato de que, muito embora a memória coletiva diga respeito a heranças que nos são legadas do passado, ela está muito mais ligada à forma como imprimimos sentido ao estado de coisas da atualidade. Esta referência do decorrido é uma das estratégias a partir das quais nós semantizamos o mundo, de tal forma, que o atual funciona mesmo como o ponto de partida a partir do qual nós podemos construir este passado que nos serve como guia.

É a partir desta circularidade envolvida nos processos de semantização a partir do decorrido - bem como tendo como pano de fundo a noção de que a transmissão do passado envolve ao mesmo tempo um problema de comunicação e um problema de linguagem - que Pierre Nora define o termo lugar de memória como determinados arranjos culturais nos quais nós imaginamos o nosso próprio passado a partir de práticas representacionais que definem concepções específicas de identidades. Trata-se de determinados espaços (que podem ser formados a partir de monumentos, personagens e/ou narrativas) que, ao mesmo tempo em que unem determinadas comunidades em torno de valores e identidades sociais comuns, também desenham um quadro polirreferencial que pode ser usado como legitimação para diferentes propostas e ideologias políticas.

Em outros termos, são práticas representacionais relacionadas a determinados discursos circulantes uma vez que são constituídas a partir de um conjunto de enunciados com uma visada definicional a respeito do passado e das relações que são permitidas de serem feitas entre este decorrido e a atualidade.

De acordo com Nora (1996a: XVII), "se a expressão lugar de memória pudesse ter uma definição oficial, ela seria esta: um lugar de memória é qualquer entidade significante, material ou não material em sua natureza, que por força da vontade humana ou pelo trabalho do tempo tenha se tornado um elemento simbólico da herança memorial de dada comunidade".

\footnotetext{
1 "Essas duas formas de um povo prestar contas a si mesmo não são mutuamente excludentes, mas ocorrem frequentemente na mesma história. A história nacional é a representação do caráter ou instituição essencial de um povo seguida do elogio ou condenação (implícitos ou explícitos) de suas ações coletivas subsequentes. Um determinado período do passado é geralmente tomado como o início ideal, a era constitutiva, o ponto de partida com base no qual se julgarão os períodos seguintes e se justificarão as atuais circunstâncias da nação" (SETERS, 2008: 20).
} 
Como um dos lugares de memória apontados pelo historiador está, justamente, o incontável número de narrativas históricas que são mediadas pelos meios de comunicação de massa.

Isso remete ao fato de que as narrativas sobre o passado não estão circunscritas aos professores e pesquisadores de história. Significa, simplesmente, que a nossa visão do passado é desenhada a partir de diversas fontes: não apenas a partir das narrativas dos livros e das aulas escolares, mas também dos romances e filmes históricos, dos jornais, das estórias em quadrinhos, das mídias eletrônicas, das novelas, das revistas informativas, entre outros produtos midiáticos. As implicações disso não são pequenas e dizem respeito mesmo a noção de que com essa "massa caleidoscópica de fragmentos nós fazemos e refazemos modelos de entendimento que explicam a natureza e a origem do mundo em que vivemos. E fazendo isso, nós definimos e redefinimos o lugar que nós ocupamos no mundo" (MORRIS-SUZUKI, 2005: 2).

Os suportes ou técnicas comunicacionais que podem servir de base para a difusão das memórias coletivas não são exatamente novos. Na Idade Média, por exemplo, as pinturas eloquentes que mostravam visadas do Inferno, do Paraíso ou do Purgatório eram eficientes modos de inscrição de lugares de memória na medida em que rememoravam determinadas figuras exemplares dos ensinamentos cristãos, comemorando, desta forma, alguns dos acontecimentos fundadores desta cultura religiosa (YATES, 2007). Nesse mesmo sentido, podemos conceber que os produtos midiáticos que retratam o passado (tais como produções jornalísticas, cinematográficas ou radiofônicas) podem ser tomados como algumas de suas expressões, na medida em que articulam narrativas coerentes em torno de um passado comum que alcança um vasto número de pessoas.

Jacques Le Goff (2003) insere mesmo a imprensa em um contexto de aumento da oferta da memória coletiva - que deixa de ser matéria somente de museus, arquivos e túmulos. Isso porque a invenção da prensa teria revolucionado a memória ocidental uma vez que, com a massificação dos impressos, o leitor pode ter contato com um volume enorme de memórias coletivas. Segundo Le Goff, é a memória jornalística que, ao lado da memória diplomática, promove "a entrada em cena da opinião pública nacional e internacional, que constrói também a sua própria memória” (LE GOFF, 2003: 455).

John B. Thompson (1998) tem uma perspectiva interessante neste sentido quando afirma que as tradições, definidas como quaisquer coisas que são transmitidas ou trazidas do passado, não foram extintas pela modernidade. Muito pelo contrário, a 
midiatização teria dado uma vida nova às tradições na medida em que as libertam das interações face a face.

Muito embora as tradições ainda mantenham muito de sua força enquanto articuladores de sentido para o mundo e enquanto criadores de um sentimento de pertença, o material simbólico que as compõe estaria cada vez mais apartado da interação social em ambientes comuns. E, assim, muito embora as tradições não tenham desaparecido, elas perderiam cada vez mais a sua ancoragem nos locais compartilhados da vida cotidiana. Dentro desse contexto, as práticas midiáticas ganhariam um estatuto privilegiado, na medida em que passam a ser um dos principais articuladores desta presença do passado em meio ao devir dos acontecimentos do presente.

Diante desta quantidade de representações culturais que se ocupam do passado filmes, programas televisivos, produções noticiosas, conteúdos especializados devemos ficar atentos para o fato de que a forma como o passado é conectado á atualidade encontra determinadas especificidades em cada um destes veículos midiáticos.

Pierre Sorlin (2009: 45) chama a atenção, por exemplo, para o fato de que a estrutura envolvida na representação do passado posta em operação por um filme ou por um romance histórico não difere essencialmente do raciocínio implicado nas narrativas que os próprios historiadores impõem a seus estudos. E isso porque ambos estariam presos às regras e convenções da narrativa clássica. Tanto historiadores quanto romancistas fazem uma montagem regida por um conjunto de motivos que se estruturam em uma estória que se desenrola rumo a uma conclusão previsível.

O jornalismo não. Ele parte de uma apropriação do passado que é totalmente diferente na medida em que não se estrutura a partir de um relato fechado em torno do decorrido, mas sim, se usarmos os termos de Sorlin, se comporta como um "devorador da História”. O passado não é o objeto da narrativa em si, mas sim, apenas um dos elementos de uma estória mais ampla. "Avaliar o peso da História" na imprensa "é penoso na medida em que se trata de uma aplicação lacunar, feito de citações, quase sempre breves" (SORLIN, 2009: 46). Como as preocupações centrais do jornalismo estão em torno dos temas da atualidade, o passado aparece quase sempre como um detalhe significante, de modo que as apropriações adquirem características inteiramente diferentes das envolvidas nos filmes ou romances históricos.

Como atesta Jill Edy, "já se tornou um clichê afirmar que os jornalistas escrevem o primeiro rascunho da História. Uma atenção muito menor tem sido prestada para aqueles que fazem a reescrita. Frequentemente, os segundos rascunhos da História 
também são escritos por jornalistas" (EDY, 1999: 72). Sobre este assunto, a autora insiste que as histórias apresentadas na mídia, por toda a carga emocional que se revestem, são muito mais impressionantes do que a apresentada em sala de aula. Além disso, enquanto a sala de aula ensina a história com uma cuidadosa atenção especial para a apresentação objetiva dos fatos, a mídia pode encorajar algumas conexões pessoais com o passado que está associado à memória coletiva ${ }^{2}$.

É sob a perspectiva destes estudos que tentam realocar o papel do passado na construção da narrativa jornalística que Barbie Zelizer pode afirmar que há, entre historiadores e jornalistas, uma espécie de disputa pelo poder de fala a respeito de determinadas temáticas comuns ${ }^{3}$.

A partir destas premissas, a forma como a imprensa utiliza o passado para explicar as notícias do presente revelaria uma dinâmica própria dos processos de ressignificação implicados na comunicação e transmissão do passado. É justamente o estudo dessa apropriação do passado feita pelo material jornalístico e os efeitos de sentido produzidos a partir desta apropriação que são as temáticas centrais do estudo proposto neste trabalho.

Mais especificamente, e partindo da concepção de que o passado funciona muitas vezes como um mecanismo de semantização do mundo, estudaremos, dentro do escopo da Linguagem e Produção de Sentido em Comunicação, de que forma o recurso à história também se constitui como uma estratégia de semantização do evento jornalístico, a partir de suas regras próprias e da complexidade inerente às práticas midiáticas. Para isso, investigaremos, de um lado, a forma como o recurso à história funciona como um poderoso recurso legitimador de algumas características da imprensa interpretativa semanal e, de outro, a maneira pela qual o passado, enquanto articulador de sentidos, circunscreve os eventos do presente relatados pelas narrativas jornalísticas dentro de um conjunto de significados já estabelecidos.

\footnotetext{
${ }^{2}$ Esse forte elemento identitário presente nesta apropriação do passado pelos jornalistas é explorado também por outros autores. A partir de uma vasta pesquisa sobre o uso de referências históricas nos jornais norte-americanos do século XIX, Betty Houchin Winfield e Janice Hume (apud KITCH, 2005: 2) concluíram que o jornalismo foi a primeira instituição a criar uma narrativa pública sobre a identidade do país. A imprensa, nesse caso, teria precedido os primeiros livros sobre a História norte-americana na função de fornecer um passado comum coerente e sólido na construção das identidades nacionais.

${ }^{3}$ Ao discorrer sobre como a mídia retratou a morte do presidente Kennedy anos após o fato, a autora apontou para a existência de uma autoridade cultural atribuída aos jornalistas que fez com que eles se estabelecessem como as vozes autorizadas para falar da história da morte do trigésimo quinto presidente norte americano. Segundo a autora, a cobertura do assassinato de Kennedy revolucionou a prática jornalística norte americana não só porque demandou um envio rápido de informações durante um período de crise, mas também por ter legitimado o jornalismo televisivo como um mediador da experiência pública nacional. A partir dessa legitimação inicial, no entanto, a discussão não se limitou ao ensino de determinadas práticas jornalísticas. A discussão se estendeu para a valorização dos profissionais da mídia enquanto atores legítimos na interpretação da realidade e da História norte americana.
} 
A partir da noção de que o acontecimento jornalístico é uma espécie de "acontecimento segundo", na medida em que não é algo que meramente "irrompe na superfície lisa da história" (RODRIGUES, 1990), mas sim, algo que está sujeito a um processo de construção de lugares de sentido que dão forma a um evento relatado, podemos dizer que a citação à história é uma estratégia eficiente de inserir a notícia dentro de um conjunto de significações já compartilhadas. Como coloca Hall (1993: 226), “um acontecimento só 'faz sentido' se puder colocar num âmbito de conhecidas identificações sociais e culturais". E assim, "se os jornalistas não dispusessem - mesmo de forma rotineira - de tais 'mapas' culturais do mundo social, não poderiam 'dar sentido' aos acontecimentos invulgares, inesperados e imprevisíveis que constituem o conteúdo básico do que é "noticiável'”.

Recorrer ao passado é, dentro desta perspectiva, uma maneira de acionar um desses mapas culturais que formam o acontecimento jornalístico. E, sob este aspecto, o evento jornalístico é semantizado justamente a partir da posição que ele ocupa dentro de uma cadeia temporal complexa, de forma que o passado e o futuro funcionam como parâmetros que delimitam a forma como o presente deve ser entendido.

A mesma lógica circular, no entanto, que rege a construção da memória coletiva, conforme colocamos anteriormente, funciona também para o fato jornalístico que usa a história como estratégia de semantização do novo. Como coloca Quérè (2005: 61-62), para que possamos associar um determinado passado e um determinado futuro para um acontecimento é necessário, antes de tudo, que o próprio acontecimento ocorra, ou seja, é preciso que ele se manifeste como descontinuidade do continnum e, mais do que isso, que "tenha sido identificado de acordo com uma certa descrição e em função de um contexto de sentido". Somente depois desta semantização primeira é que podemos lhe associar um passado e um futuro como modelos de explicação causal. E assim, "é, portanto o acontecimento que acaba de se verificar que faz aparecer a dimensão do passado; porque antes de ele se verificar não há passado. É preciso que se produza o acontecimento para que haja um passado do acontecimento". Dentro desse quadro, é o próprio acontecimento jornalístico já semantizado que irá construir o passado e o futuro que servirão de guia para o entendimento do relatado, erguendo, assim, determinados quadros de significação.

É a partir deste conjunto de problemas que posicionamos os objetivos da presente pesquisa. E a partir disso, estudaremos, portanto, a forma pela qual, ao evocar a História, o jornalismo invoca a edificação de lugares de sentido. 


\section{INTRODUÇÃO}

\section{ENTRE A URDIDURA DE ENREDO E OS CONTEÚDOS IMPLÍCITOS: O JOGO ENTRE O ATUAL E O DECORRIDO NAS REVISTAS SEMANAIS}

Com o intuito de investigar essa apropriação do passado posto em operação pelas narrativas jornalísticas, o presente trabalho propõe o estudo das alusões históricas nas quatro revistas informativas e interpretativas de maior circulação do país (Veja, Época, IstoÉ e Carta Capital $^{4}$ ). O material de estudo é composto, portanto, pelas matérias publicadas durante o ano de 2009 nas quatro revistas citadas que utilizem dados históricos em sua composição.

Para estudar com a história atua na semantização dos fatos noticiados na imprensa - bem como os aspectos interdiscursivos existentes entre a narrativa da História e a apresentação do presente posta em operação pela narrativa jornalística -, utilizaremos como parâmetros de análise, por um lado, os efeitos de sentido que são mobilizados a partir da inserção dos dados históricos na construção das narrativas das reportagens; e, por outro, os intertextos e os interdiscursos que são mediados a partir do jogo de reenvio mobilizado por essas narrativas históricas inseridas.

A importância do papel da história no processo evenemencial que transforma o fato em notícia pode ser aludido a partir do grande número de reportagens que utilizam este retorno ao passado como estratégia enunciativa e argumentativa. Para se ter ideia, as revistas Veja, Época, IstoÉ e Carta Capital publicaram, juntas, no período de Janeiro a Dezembro de 2009, um total de 6.489 matérias $^{5}$. Destas, 4.423 faziam menção a algum evento anterior ao ano de $1995^{6}$ - ou seja, que havia acontecido ao menos quinze anos antes da veiculação da reportagem -, o que corresponde a aproximadamente $70 \%$ dos textos publicados.

A forma como este material coletado é distribuído ao longo dos meses, no período de Janeiro a Dezembro de 2009 pode ser observado na seguinte tabela:

\footnotetext{
${ }^{4}$ De acordo com os dados da ANER, a revista Veja foi a revista com a maior circulação média durante o ano de 2009, com um total de 1.098 .182 exemplares entre os meses de Janeiro e Novembro. Ela foi seguida por Época, com 413.954 e depois por IstoÉ, com 342.954. A revista Carta Capital, levando-se em consideração todas as revistas publicadas no Brasil, ocupou a $22^{\mathrm{a}}$ posição, com uma circulação de 31.859 exemplares. Ela ocupa, contudo, a quarta posição no ranking das revistas consideradas informativas. Mesmo com a disparidade nas tiragens - afinal, a revista Veja ocupou 28,26\% do mercado revisteiro deste ano, enquanto a Carta Capital ficou com apenas 0,82\% -, a comparação entre elas é relevante, pois procuraremos indicar que as características de cada uma dessas revistas não diferem muito entre si, dizendo respeito, mesmo a uma característica própria deste gênero de jornalismo.

${ }^{5}$ Entende-se por "matéria" os textos que ocupam uma página ou mais da revista. As notas informativas, neste caso, estão excluídas do corpus.

${ }^{6}$ As justificativas para esta escolha metodológica serão esmiuçadas no tópico 1 do presente capítulo.
} 


\begin{tabular}{|cccc}
\hline Janeiro & $\begin{array}{c}\text { Total de matérias } \\
\text { publicadas }\end{array}$ & $\begin{array}{c}\text { Matérias com } \\
\text { remissões históricas }\end{array}$ & Porcentagem \\
\hline Fevereiro & 397 & 273 & $68,76 \%$ \\
Março & 487 & 344 & $70,63 \%$ \\
Abril & 554 & 362 & $65,34 \%$ \\
Maio & 592 & 428 & $72,29 \%$ \\
Junho & 521 & 358 & $68,71 \%$ \\
Julho & 525 & 339 & $64,57 \%$ \\
Agosto & 588 & 407 & $69,21 \%$ \\
Setembro & 534 & 349 & $65,35 \%$ \\
Outubro & 596 & 398 & $66,77 \%$ \\
\hline Novembro & 533 & 378 & $70,91 \%$ \\
\hline Dezembro & 559 & 369 & $66,01 \%$ \\
TOTAL & 603 & 418 & $69,32 \%$ \\
\hline Legenda: A porcentagem diz respeito às matérias com remissões históricas em relação ao total de \\
\hline matérias publicadas
\end{tabular}

Podemos notar que os meses com maior concentração de alusões históricas nas reportagens é abril, com um total de $72,29 \%$ dos textos publicados. O de menor concentração é junho, com uma média de $64,57 \%$ das reportagens produzidas. Podemos notar, portanto, que não há uma variação muito grande entre um mês e outro. A quantidade de material histórico aludido é relativamente constante nos meses pesquisados.

Esta média elevada de reportagens que contém dados históricos em sua composição é bastante significativa e alude mesmo para a possibilidade de que a remissão a dados do passado possam se constituir como uma característica presente nas narrativas deste tipo de jornalismo. É justamente em torno disso que articularemos a nossa investigação.

Também se trata de uma característica que não diz respeito a apenas um dos veículos estudados. Separando o material coletado em cada uma das revistas analisadas, levando-se em consideração o total de matérias publicadas (T) em relação ao total de matérias que continham remissões históricas $(\mathrm{RH})$ nos meses pesquisados, obteremos a seguinte tabela: 


\begin{tabular}{|c|c|c|c|c|c|c|c|c|c|c|c|c|}
\hline & \multicolumn{3}{|c|}{ Veja } & \multicolumn{3}{|c|}{ Época } & \multicolumn{3}{|c|}{ Istó́ } & \multicolumn{3}{|c|}{ Carta Capital } \\
\hline & $\mathbf{T}$ & H & $\%$ & $\mathbf{T}$ & $\mathbf{H}$ & $\%$ & $\mathbf{T}$ & $\mathbf{H}$ & $\%$ & $\mathbf{T}$ & $\mathbf{H}$ & $\%$ \\
\hline $\mathbf{J}$ & 109 & 81 & $74,31 \%$ & 123 & 82 & $66,66 \%$ & 88 & 50 & $56,81 \%$ & 85 & 60 & $70,59 \%$ \\
\hline $\mathbf{F}$ & 114 & 80 & $70,18 \%$ & 128 & 91 & $71,09 \%$ & 125 & 74 & $59,20 \%$ & 120 & 99 & $82,5 \%$ \\
\hline $\mathbf{M}$ & 120 & 89 & $74,17 \%$ & 173 & 111 & $64,16 \%$ & 125 & 74 & $59,20 \%$ & 136 & 88 & $64,71 \%$ \\
\hline $\mathbf{A}$ & 137 & 95 & $69,34 \%$ & 133 & 99 & $74,44 \%$ & 159 & 104 & $65,40 \%$ & 163 & 130 & $79,75 \%$ \\
\hline $\mathbf{M}$ & 117 & 79 & $67,52 \%$ & 144 & 95 & $65,97 \%$ & 127 & 75 & $59,04 \%$ & 133 & 109 & $81,95 \%$ \\
\hline $\mathbf{J}$ & 115 & 82 & $71,30 \%$ & 159 & 105 & $66,04 \%$ & 132 & 71 & $53,78 \%$ & 119 & 81 & $68,07 \%$ \\
\hline $\mathbf{J}$ & 142 & 103 & $72,53 \%$ & 141 & 97 & $68,79 \%$ & 154 & 97 & $62,98 \%$ & 151 & 110 & $72,84 \%$ \\
\hline $\mathbf{A}$ & 114 & 81 & $71,05 \%$ & 188 & 113 & $60,10 \%$ & 121 & 79 & $65,28 \%$ & 111 & 76 & $68,46 \%$ \\
\hline $\mathbf{S}$ & 144 & 115 & $79,86 \%$ & 143 & 92 & $64,33 \%$ & 152 & 93 & $61,18 \%$ & 157 & 98 & $62,42 \%$ \\
\hline 0 & 129 & 96 & $74,41 \%$ & 141 & 104 & $73,75 \%$ & 134 & 80 & $59,70 \%$ & 129 & 98 & $75,96 \%$ \\
\hline $\mathbf{N}$ & 130 & 81 & $62,30 \%$ & 167 & 110 & $65,86 \%$ & 140 & 81 & $57,85 \%$ & 122 & 97 & $79,50 \%$ \\
\hline D & 180 & 127 & $70,55 \%$ & 135 & 98 & $72,59 \%$ & 166 & 111 & $66,86 \%$ & 122 & 82 & $67,21 \%$ \\
\hline $\mathbf{t}$ & 1551 & 1109 & $71,50 \%$ & 1775 & 1197 & $67,43 \%$ & 1623 & 989 & $60,93 \%$ & 1548 & 1128 & $72,86 \%$ \\
\hline
\end{tabular}

Legenda: $\mathbf{T}=$ total de matérias publicadas; $\mathbf{H}=$ matérias com remissões históricas; $\boldsymbol{\%}=$ porcentagem de matérias com remissões históricas em relação ao total de matérias publicadas; $\mathrm{t}=$ soma total

A média do número de reportagens que continham remissões históricas mostra que todas as revistas se utilizam deste recurso com pequenas variações entre uma e outra. A publicação que mais se utiliza deste recurso é a Carta Capital (com um total de $72,86 \%$ das matérias publicadas fazendo algum tipo de evocação do passado). Ela é seguida por Veja (com 71,50\%) e por Época (com 67,43\%). A revista que menos faz utilização deste recurso é a revista $I s t o E ́$, com 60,93\% de matérias que fazem menção a algum tipo de dado histórico.

Se olharmos para os meses individualmente, notaremos que a Carta Capital também possui a maior média mensal, em fevereiro, com um total de 82,5\% de matérias que continham alusões históricas. Ela é seguida, na mesma publicação, pelo mês de maio (com $81,95 \%$ ). A próxima maior média mensal está na revista Veja no mês de Setembro, com 79,86\% do total de textos. Em Época, a maior média mensal está no mês de abril, com 74,44\% dos textos e, em IstoÉ, no mês de Dezembro, com 66,86\%.

Como podemos notar, também, não há, contudo, uma variação muito significativa em relação às revistas estudadas. A distribuição dos dados históricos é, assim, relativamente constante nas reportagens jornalísticas dos quatro veículos. 
Podemos olhar ainda mais detidamente e fazermos uma análise em termos da variação da aparição de matérias em cada uma das edições destas revistas. Na tabela abaixo, alocamos, de um lado, as edições que possuem maior porcentagem de matérias que possuem remissões históricas e, de outro, as que possuem a menor porcentagem, em cada um dos veículos estudados:

\begin{tabular}{c|cccc|} 
& Veja & Época & IstoÉ & Carta Capital \\
\hline Maior \% & $85,71 \%$ & $83,87 \%$ & $84,37 \%$ & $97,56 \%$ \\
& $(23 / 09 / 2009)$ & $(05 / 10 / 2009)$ & $(01 / 07 / 2009)$ & $(27 / 05 / 209)$ \\
Menor \% & $56,41 \%$ & $51,42 \%$ & $41,66 \%$ & $50 \%$ \\
Média & $(18 / 11 / 2009)$ & $(09 / 03 / 2009)$ & $(21 / 10 / 2009)$ & $(23 / 09 / 2009)$ \\
(todas as edições) & $71,50 \%$ & $67,43 \%$ & $60,93 \%$ & $72,86 \%$
\end{tabular}

Quanto às edições tomadas individualmente, a revista Carta Capital do dia $27 \mathrm{de}$ maio, possuía um total de $97,56 \%$ de reportagem que faziam alusão a algum evento anterior ao ano de 1995. Apenas uma matéria deste número não possuía um dado histórico. Em Carta Capital, a edição com menor número de alusões históricas é a do dia 23 de setembro, com uma média de $50 \%$ dos textos.

$\mathrm{Na}$ revista Veja, a edição com maior número de remissões é a do dia 23 de setembro com um total de $85,71 \%$ dos textos e o menor número é a do dia 18 de novembro, com 56,41\% das reportagens. Em Época, a variação fica entre 83,87\% das matérias, na edição de 05 de outubro e 51,42\%, na edição de 09 de março. Por fim, em $I s t o E ́$, a edição com maior número de remissões históricas é a de 01 de julho, com $84,37 \%$ dos textos e a com menor número é a de 21 de outubro com $41,66 \%$ dos textos.

Um dado relevante a ser destacado é o de que no período de Janeiro a Dezembro de 2009 foram estudadas 205 edições, somadas as quatro revistas. Destas, apenas em seis edições (3\% delas) a porcentagem de matérias que citavam dados históricos foi inferior a 50\%. E todas elas estão nas revistas IstoÉ, a saber, nos dias 25/02/2009 (com 42,42\%), 04/03/2009 (com 46,87\%), 03/06/2009 (com 41,17\%), 29/07/2009 (com 46,42\%), 02/09/2009 (com 44,44\%) e 21/10/2009 (com 41,66\%).

Ou seja, nas demais revistas consultadas, todas as edições possuíam mais da metade de seus textos com algum tipo de remissão a algum evento anterior ao ano de 1995. Estes dados já podem dar uma ideia do tamanho da importância das alusões históricas para a construção do fato jornalístico na imprensa interpretativa de revista. 
Há, no entanto, um outro dado que deve ser levado em consideração. Há, basicamente, dois modelos a partir dos quais as revistas informativas semanais mobilizam o passado em suas narrativas. Em um deles, o decorrido estabelece uma espécie de continuum em relação à atualidade e diz respeito mesmo ao desenvolvimento de uma determinada temática ao longo do tempo até o presente. Em outras palavras, trata-se de um contexto histórico que nos informa como chegamos até aqui. Em outras matérias, a relação é diferente e, ao invés de uma idéia de continuidade explicativa entre o passado e o presente, a narrativa estabelece alguns momentos-chave do passado que servem como um modelo de comparação ou de analogia com a atualidade. Não há necessariamente, nestas matérias, uma relação de origem lógica entre o passado e o presente, mas sim, o apontamento de situações similares que são confrontadas.

Podemos encontrar esses dois modos de lidar com o passado, nas revistas analisadas, na seguinte proporção em cada uma delas:

\begin{tabular}{|c|c|c|}
\hline & $\begin{array}{l}\text { Relação de continuidade } \\
\text { explicativa entre o passado e o } \\
\text { presente }\end{array}$ & $\begin{array}{l}\text { Relação de cotejo, confronto ou } \\
\text { comparação entre o passado e o } \\
\text { presente }\end{array}$ \\
\hline Veja & $852(43,78 \%)$ & $1094(56,21 \%)$ \\
\hline Época & $987(45,84 \%)$ & $1166(54,15 \%)$ \\
\hline IstoÉ & $871(54,50 \%)$ & $727(45,49 \%)$ \\
\hline Carta Capital & $993(48,48 \%)$ & $1055(51,51 \%)$ \\
\hline TOTAL & $3703(47,81 \%)$ & $4042(52,18 \%)$ \\
\hline
\end{tabular}

Como pode ser notado na tabela, estes dois tipos de narrativas históricas aparecem com bastante frequência e em uma proporções bastante parecidas nas quatro revistas analisadas durante o ano de 2009. Em todas elas, os dois tipos de narrativas ocupam aproximadamente metade das remissões históricas, com pequenas variações entre uma revista e outra. Trata-se de um dado importante porque assim podemos entrever com qual tipo de dado histórico estamos lidando nestas revistas, ou seja, estamos diante tanto de narrativas que suturam o presente e o passado tanto através de uma relação de continuidade explicativa quanto a partir do confronto do presente com pontos-chave do passado.

Uma vez esmiuçados os dados gerais, podemos investigar algumas questões mais específicas. Se separarmos estas matérias de acordo com as editorias em que elas ocupavam nas revistas, poderemos ver que as recorrências à história afeta a todas elas. Em relação ao total do corpus, cada editoria recobre o seguinte quadro: 


\begin{tabular}{|c|c|c|c|c|c|c|c|c|}
\hline & \multicolumn{2}{|c|}{ Veja } & \multicolumn{2}{|c|}{ Época } & \multicolumn{2}{|c|}{ IstoÉ } & \multicolumn{2}{|c|}{ Carta Capital } \\
\hline & Total & $\%$ & Total & $\%$ & Total & $\%$ & Total & $\%$ \\
\hline Editoriais & 31 & $2,79 \%$ & 33 & $2,75 \%$ & 17 & $1,71 \%$ & 40 & $3,54 \%$ \\
\hline Economia & 127 & $11,45 \%$ & 131 & $10,94 \%$ & 39 & $3,94 \%$ & 203 & $17,99 \%$ \\
\hline Política & 309 & $27,86 \%$ & 322 & $26,90 \%$ & 252 & $25,48 \%$ & 296 & $26,24 \%$ \\
\hline Sociedade & 128 & $11,54 \%$ & 160 & $13,36 \%$ & 130 & $13,14 \%$ & 105 & $9,30 \%$ \\
\hline Comportamento & 101 & $9,10 \%$ & 91 & $7,60 \%$ & 111 & $11,22 \%$ & 28 & $2,48 \%$ \\
\hline Cultura & 264 & $23,80 \%$ & 284 & $23,72 \%$ & 310 & $31,34 \%$ & 324 & $28,72 \%$ \\
\hline $\begin{array}{c}\text { Ciência e } \\
\text { Tecnologia }\end{array}$ & 80 & $7,21 \%$ & 78 & $6,51 \%$ & 55 & $5,56 \%$ & 55 & $4,87 \%$ \\
\hline Meio Ambiente & 42 & $3,78 \%$ & 50 & $4,17 \%$ & 45 & $4,55 \%$ & 25 & $2,21 \%$ \\
\hline Esportes & 27 & $2,43 \%$ & 48 & $4,01 \%$ & 30 & $3,03 \%$ & 52 & $4,60 \%$ \\
\hline
\end{tabular}

A partir da tabela, percebemos que em Época e Veja há um grande número de matérias que citam dados históricos na editoria de política. Isso está em grande parte relacionado à maior quantidade de matérias publicadas neste setor, se comparada aos demais. A segunda é editoria de cultura. Em Carta Capital e IstoÉ, essa relação se inverte e o maior número de remissões históricas está na editoria de cultura (com $28,72 \%$ e $31,34 \%$, respectivamente, em relação ao total das revistas), seguida da de política (com 26,24\% e 25,48\%, respectivamente). O grande número de matérias na editoria de cultura está relacionado, principalmente, ao lançamento de livros sobre personagens ou eventos históricos de importância e não tanto a um tipo de explicação sobre algum evento do tempo presente.

Outro dado relevante a ser notado é que mesmo em editorias que normalmente pensamos estar bastante associadas a temas da atualidade, a incidência de matérias com remissões históricas é bastante acentuada. Podemos notar isso, por exemplo, no setor de economia (com uma participação de aproximadamente 11,3\% de todo material coletado que continha remissões históricas) e ciência e tecnologia (compondo em torno de $6 \%$ do material separado).

Os dados históricos coletados também compõem o material jornalístico da revista tanto em seus textos explicitamente informativos quanto nos artigos dos 
colunistas e comentadores. Se dividirmos as matérias coletadas em termos daquelas que se referem ao jornalismo opinativo e aquelas que compõem o material informativo da revista, obteremos a seguinte tabela:

\begin{tabular}{ccccccc|} 
& \multicolumn{3}{c}{ INFORMATIVAS } & \multicolumn{3}{c|}{ OPINATIVAS } \\
& Total & RH & $\%$ & Total & RH & $\%$ \\
Veja & 1301 & 932 & $71,63 \%$ & 249 & 177 & $71,08 \%$ \\
Época & 1466 & 1013 & $69,09 \%$ & 308 & 184 & $59,74 \%$ \\
IstoÉ & 1465 & 895 & $61,09 \%$ & 158 & 94 & $59,49 \%$ \\
Carta & 1174 & 860 & $73,25 \%$ & 388 & 268 & $69,07 \%$ \\
Capital & 5406 & 3700 & $\mathbf{6 8 , 4 4 \%}$ & 1103 & 723 & $\mathbf{6 5 , 5 4 \%}$ \\
TOTAL & & & &
\end{tabular}

Legenda: Total $=$ total de matérias publicadas em cada categoria na publicação como um todo RH: total de matérias publicadas na categoria e que continham remissões históricas;

$\%$ = porcentagem de matérias publicadas na categoria e que continham remissões históricas em relação ao total de matérias publicadas na categoria.

Estes dados indicam que as remissões históricas são comumente utilizadas nos dois tipos de materiais jornalísticos, com pequenas variações entre um e outro. Somadas as duas revistas, o material informativo que faz remissões a eventos históricos corresponde a $68,44 \%$ do material informativo que compõe as publicações e o opinativo participa com uma porcentagem de $65,54 \%$.

Estes dados mostram como a alusão a fatos históricos recobre mesmo uma quantidade bastante vasta das narrativas jornalísticas presentes nas revistas informativas e interpretativas semanais (sendo que algo em torno de $70 \%$ dos textos publicados possui alguma informação sobre fatos do passado) e perpassa mesmo os diversos textos que são veiculados por elas - recobrindo as diversas editorias, bem como tanto os textos informativos quanto os opinativos.

Com estes dados, procuramos mostrar que há uma grande quantidade de material jornalístico que utiliza dados históricos em suas composições nas revistas informativas interpretativas semanais.

Diante disso, para que possamos analisar estes dados, precisamos levar em consideração que semantizar o fato jornalístico, de uma maneira geral, diz respeito tanto á montagem de determinados enredos narrativos quanto à mobilização de determinados inventários de discursos. Assim, para estudarmos como esta evocação do passado atua como uma estratégia de semantização do fato jornalístico, a análise empírico-analítica deste material coletado será feita a partir de uma metodologia comparativa de origem 
híbrida que abarque a análise da narrativa jornalística, além de metodologias específicas de análise de discurso.

\section{A urdidura de enredo, os pressupostos e os subentendidos: elementos da semantização do fato jornalístico}

Se adotarmos a visão de Hayden White (1994: 98) de que as narrativas referenciais são "ficções verbais cujos conteúdos são tanto inventados quanto descobertos" e cujas formas tem muito em comum com as narrativas literárias, a análise estrutural da narrativa é um instrumental teórico e metodológico de importância considerável para investigarmos como a história atua no processo de semantização do fato jornalístico.

Sobre esse assunto, uma primeira distinção precisa ser feita: um conjunto de eventos isolados (sejam acontecimentos do passado, assunto da história, ou do presente, material do jornalismo) não constitui, por si só, uma narrativa e oferece, no máximo, os elementos necessários para a formação desta. Estes somente podem pensados como tal quando postos em relação, ou seja, através da "supressão ou subordinação de alguns deles e pelo realce de outros, por caracterização, repetição do motivo, variação do tom e do ponto de vista, estratégias descritivas alternativas e assim por diante". É neste sentido que tanto a narrativa histórica quanto a narrativa jornalística se estruturam a partir do mecanismo de urdidura de enredo que consiste, justamente, na operação que transforma os acontecimentos postos em uma simples ordem cronológica temporal em propriamente uma estória. Trata-se mesmo da operação que transforma a crônica em narrativa e que se manifesta na "capacidade de criar uma estória plausível a partir de uma congérie de fatos que, na sua forma não-processada, carecia absolutamente de sentido" (WHITE, 1994: 100).

Esta noção está ligada ao fato de que um mesmo conjunto de fatos pode ser contado de maneiras totalmente diferentes - e, principalmente, pode gerar uma série de produções de sentido diferenciadas - a partir do modo em que se objetiva a urdidura de enredo. E isso porque ainda que se conte uma estória tendo como parâmetros de composição unicamente uma ordem cronológica e sintaticamente estruturada, a ênfase dada para cada evento da série determina uma consequência inteiramente outra para a produção do sentido.

Tomemos o exemplo do próprio White (1994: 109): para um determinado conjunto de eventos “(1) a, b, c, d, e, ..., n”, podemos estruturar a narrativa de uma série de maneiras diferentes sem violar a sua ordem cronológica, somente modificando a 
ênfase explicativa em um determinado ponto da cadeia. Essas estruturações poderiam ser concebidas dos seguintes modos, sendo que a letra maiúscula representa o status privilegiado da força explicativa de um elemento (apud WHITE, 1994: 109):

(2) A, b, c, d, e, ..., n

(3) a, B, c, d, e, ..., n

(4) a, b, C, d, e, ..., n

(5) a, b, c, D, e, ..., n

(6) a, b, c, d, E, ..., n

É a isso que remete a urdidura de enredo, portanto: à passagem de uma visão ingênua de crônica (que supõe que a simples ordenação dos eventos na sua sequência temporal como princípio suficiente da explicação) para a estória ou narrativa (que dão outros sentidos para as interpretações além da mera seriação).

Tendo em vista essas noções combinadas com a ideia de que a análise estrutural da narrativa estuda "não a obra, mas as virtualidades do discurso literário que o tornam possível" (TODOROV, 1976: 209), Claude Bremond (1976: 114) elabora mesmo algumas condições prévias para que um texto possa ser considerado uma narrativa. Segundo este autor, "onde não há sucessão, não há narrativa”, uma vez que se os objetos do discurso são associados apenas por uma contiguidade espacial, estaremos diante de uma mera descrição.

Além disso, "onde não há integração na unidade de uma ação, não há narrativa, mas somente cronologia", ou seja, apenas uma "enunciação de uma sucessão de fatos não coordenados". Por fim, não existe narrativa quando o interesse humano não está posto, uma vez que "é somente por relação com um projeto humano que os acontecimentos tomam significação e se organizam em uma série temporal estruturada" (BREMOND, 1976: 114).

Isso posto, podemos entender porque Roland Barthes (1976: 26) define que compreender uma narrativa não é somente seguir o esvaziamento da estória, mas sim, reconhecer nela determinados estágios. E isso significa "projetar os encadeamentos horizontais do fio narrativo sobre um eixo implicitamente vertical; ler (escutar) uma narrativa não é somente passar de uma palavra à outra, é também passar de um nível a outro". Como consequência disto, está o fato de que "a significação não está ao cabo da narrativa, ela a atravessa" (BARTHES, 1976: 26).

Dentre esses vários níveis que dotam as narrativas de significação, podemos pensar em especificamente alguns que podem funcionar como importantes conceitos operatórios para a nossa metodologia de estudo: as funções cardinais e as funções 
catálises. Entendemos por funções "todo o segmento da história que se apresenta como o termo de uma correlação" (BARTHES, 1976: 28) ou, em outras palavras, a possibilidade de determinados elementos "de entrar em correlação com outros elementos desta obra e com a obra inteira" (TODOROV, 1976: 210) ${ }^{7}$.

Ora, podemos encontrar inúmeras funções dentro de uma dada narrativa jornalística sem que estas, contudo, possuam a mesma importância ou o mesmo valor hierárquico para a significação geral do texto. Enquanto determinados conjuntos de correlações remetem a articulações da narrativa como um todo, outros não fazem mais do que completar a narrativa principal com assuntos outros que podem ser relacionados a esta trama central. É justamente a partir desta diferenciação que as funções narrativas são separadas entre funções cardinais e funções catálise: ao passo que as primeiras inauguram ou concluem uma certeza, formando um dos núcleos da narrativa principal; as segundas estão relacionadas a notações subsidiárias "que se aglomeram em torno de um núcleo ou de outro sem modificar-lhe a natureza alternativa" (BARTHES, 1976: $32)$.

A função catálise, no entanto, embora tenha um caráter secundário, não é inútil do ponto de vista da significação. Muito pelo contrário. Ao instituir um momento de descanso em meio ao fluxo principal da narrativa, ela inaugura um ponto seguro, uma pausa no que poderiam ser considerados propriamente os pontos de risco da narrativa. $\mathrm{O}$ consenso que ela sugere, no entanto, é apenas aparente: a função catálise "acelera, retarda, avança, o discurso, ela resume, antecipa, por vezes mesmo desorienta" (BARTHES, 1976: 33).

De fato, é evidente que ao passo que o núcleo da narrativa não pode ser suprimido sem prejuízo, as catálises são mais facilmente abolidas. Da mesma forma, no entanto, que não se pode apagar um dos núcleos de uma estória sem alterar-lhe substancialmente o conteúdo, também não se pode suprimir uma catálise sem alterar o discurso. Neste nível da narrativa, "o notado aparecendo sempre como notável, a catálise desperta sem cessar a tensão semântica do discurso, diz ininterruptamente: houve, vai haver significação" (BARTHES, 1976: 33-34). As catálises são expansões em relação a um núcleo e, da mesma forma que acontece com a frase, uma narrativa é infinitamente catalisável.

\footnotetext{
${ }^{7}$ Como exemplos, Todorov (1976: 210) expõe que a função (ou o sentido) "de uma metáfora é o de se opor a tal outra imagem ou de ser mais intensa que ela em muitos graus. O sentido de um monólogo pode caracterizar um personagem. É o sentido dos elementos da obra em que pensava Flaubert quando escrevia: 'não há no meu livro uma descrição isolada, gratuita; todas servem a meus personagens e têm influência longínqua ou imediata sobre a ação'. Cada elemento da obra tem um ou muitos sentidos (salvo se esta é deficiente), que são em número finito e que é possível estabelecer de uma vez por todas".
} 
Ora, uma vez que é em torno do tempo presente que a narrativa jornalística se sutura (sendo em torno disso, portanto, que as funções cardinais de seu texto se articulam), os dados históricos aparecem, justamente, enquanto funções catálise nos textos noticiosos. Como elas interferem com o tempo da narrativa, elas ligam o presente ao tempo da história. São elas que engendram um tempo histórico na narrativa jornalística e fazem as ligações com os fatos do passado. Daí a importância de estudarmos as funções catálises dentro de uma reportagem.

Isso posto, antes de tratarmos o modo como estes conceitos serão postos em operação na metodologia proposta, precisamos esmiuçar uma outra categoria de análise: a sequência. Ela diz respeito à "série lógica de núcleos, unidos entre si por uma relação de solidariedade". Em outras palavras, as sequências são as micro-séries de uma narrativa que indicam uma cadeia de eventos que tem um início e um fim definidos. A sequência é, portanto, "uma unidade lógica ameaçada: é o que a justifica a mínimo". Da mesma forma, "ela é também fundada a máximo: fechada sobre suas funções, resumida em um nome, a própria sequência constitui uma unidade nova, prestes a funcionar como o simples termo de uma outra sequência, maior" (BARTHES, 1976: 39-40).

Uma vez que os dados históricos presentes nas narrativas jornalísticas são normalmente mobilizados a partir de aplicações lacunares e de citações breves, como coloca Sorlin, o estudo da dinâmica das significações mobilizadas pelas funções e pelas sequências é de extrema importância para este trabalho. São elas que articulam os dados históricos dentro da narrativa principal, ligada ao presente, e interferem no tempo do texto, ligando a narrativa da atualidade a um tempo histórico.

Uma vez identificadas as formas pelas quais os dados históricos são costurados às narrativas jornalísticas, poderemos identificar algumas constantes narrativas temáticas. Ora, existem mesmo alguns domínios de assuntos constantes no que se refere às sequências e às funções que as reportagens normalmente utilizam quando recorrem aos dados históricos. Através de um levantamento de ordem estatística, trabalharemos sobre as constantes narrativas, nos concentrando, desta maneira, nos expedientes normalmente utilizados pelos jornalistas para dar sentido ao tempo presente através da utilização de dados históricos.

Em todas estas constantes narrativas, podemos observar bastante claramente que algumas de suas correlações se aproximam de elementos de ordem persuasiva, a partir do uso de expedientes como a construção de um real comum que possibilita, na sequência, a edificação de um vínculo entre este real e o que se quer ver comprovado. No caso das narrativas jornalísticas que utilizam dados históricos em sua composição, 
não é raro que estes sirvam justamente como uma forma de ligação imaginária entre um real que se presume consensual e um outro que se tenta construir. Essa relação, especificamente no corpus estudado, toma a forma de um passado que é já supostamente dado e de um presente a partir do qual os sentidos ainda estão em disputa.

As matérias jornalísticas coletadas podem ser separadas de acordo com algumas destas correlações que aparecem nas reportagens com certa frequência. A definição das narrativas que serão analisadas levará em consideração, portanto, o papel que elas exercem na costura entre o fato jornalístico principal retratado e o dado histórico evocado nesta construção (seja como funções ou sequências).

A partir de um levantamento no material coletado, podemos perceber que as principais constantes narrativas temáticas no que se refere tanto aos índices, quanto às funções catálises e cardinais e às sequências são as seguintes: "funções e sequências narrativas de ordem comparativa"; "funções e sequências narrativas de disjunção"; "funções e sequências narrativas de trajetórias pessoais" e, por fim, "funções e sequências narrativas de origem".

Por "funções e sequências narrativas de ordem comparativa", entendemos os elementos que põe em evidência a solidariedade entre os acontecimentos do presente e alguns eventos do passado, de forma que os dois sejam postos nos termos de uma similaridade. Essa comparação pode ser dada tanto de forma direta - nos quais as analogias e as metáforas seriam casos particulares desta possibilidade - como por meio de uma ligação de sucessão que imputa causas e consequências comuns entre o atual e o decorrido. Assim, se nos basearmos em Perelman e Olbrechts-Tyteca (1996: 299-300), poderemos pensar que os eventos que estão ligados por este vínculo de similaridade que pode indicar tanto uma sucessão, quanto uma coexistência - podem apresentar uma série de variações como:

(a) O relacionamento de dois acontecimentos por meio de uma comparação direta;

(b) A correlação de dois acontecimentos por meio de um mesmo vínculo causal;

(c) A correlação de dois acontecimentos a partir de um mesmo conjunto de consequências ou de efeitos.

São às funções e sequências deste tipo que imputaremos o nome de "funções narrativas de ordem comparativa" entre acontecimentos do passado e do presente. Estas comparações podem se dar tanto com base em estruturas do real (ou seja, "que valem-se dela [da estrutura do real] para estabelecer uma solidariedade entre juízos admitidos e outros que se procura promover") ou de forma quase-lógica (que "se apresentam como 
comparáveis a raciocínios formais, lógicos ou matemáticos") (PERELMAN e OLBRECHTS-TYTECA, 1996: 218). Faremos uma distinção também neste sentido. A diferença fundamental entre uma e outra categoria está no fato de que, na segunda, um caráter de medição deve sempre estar presente - mesmo que esta medição não possa ser totalmente verificada.

Quanto às "funções e sequências narrativas de disjunção", entendemos por este termo as estórias que relacionam um evento do passado com um do presente, só que de forma a marcar uma diferença ou uma separação fundamental entre um e outro momento. Se anteriormente falávamos do estabelecimento de um vínculo de solidariedade; agora, a questão se desloca para narrativas que se opõe ao estabelecimento de tal ligação. São, portanto, estórias que marcam uma ruptura radical entre o atual e o decorrido. Neste sentido, as narrativas deste tipo afirmam o passado apenas para indicar sua total falta de adequação ao presente.

Neste sentido, suas variações deste tipo de narrativa que podemos encontrar são como que opostas às que colocamos no caso das de ordem comparativa:

(a) O relacionamento dos dois eventos é explicitado por meio de uma ruptura importante;

(b) O vínculo causal que, de início poderia parecer similar, é mostrado como diferente ou divergente;

(c) As consequências ou efeitos dos dois acontecimentos são postas como inteiramente outras.

As "funções e sequências narrativas de origem" dizem respeito a estórias que evocam um passado para mostrar uma primeira determinante ou o início de um determinado evento, mas sem que este princípio seja posto em uma relação explícita de comparação ou de ruptura com as facetas mais recentes do acontecimento retratado.

Por fim, as "funções e sequências narrativas de trajetórias pessoais" dizem respeito a um resgate do passado nas narrativas jornalísticas relacionado à descrição da vida de um retratado ou entrevistado. Embora elas possam engendrar tanto uma narrativa de comparação quanto uma de ruptura, elas se distinguem das anteriores por tomarem os atos passados de vida como parâmetro de julgamento. Em suma, as funções e sequências narrativas de trajetórias pessoais dizem respeito ao resgate dos antecedentes de determinada pessoa de forma que seu testemunho ou a sua ação sejam julgadas a partir deste conjunto de fatos pregressos. Diz respeito às formas como um personagem é retratado dentro da narrativa e os julgamentos de valor que são postos a partir desta descrição. 
Separamos numericamente também a categoria "aspas", que corresponde aos trechos das reportagens em que algum entrevistado cita um dado histórico. Estas passagens serão apenas contabilizadas e discriminadas estatisticamente, mas não servirão de material de análise. Também foram contabilizados como "aspas" os trechos em que o jornalista faz uma citação ou uma reescrita de um conteúdo de um livro.

Por fim, separamos um tipo específico de fala que, embora apareça com menos frequência no material, não deixa de ser relevante, que diz respeito aos "ditos de personagens históricos famosos". Eles se referem aos momentos em que os jornalistas evocam a fala de alguma personalidade histórica de destaque, do tipo "como diria Julio César" ou "como Napoleão costumava explanar".

É importante notar que uma mesma reportagem pode apresentar várias destas funções em diferentes trechos. É, inclusive, bastante comum que reportagens maiores e mais complexas apresentem mesmo todas elas nas diversas passagens que a compõe. É por isso que, nas tabelas abaixo, o número total das sequências e funções narrativas é maior do que o número de matérias que possuem remissões históricas.

Para chegarmos a estes números, adotamos o seguinte procedimento: em cada reportagem, foram marcadas as funções e sequências narrativas que estavam presentes independentemente do número de trechos em que elas apareciam. Assim, mesmo em textos que possuíam duas ou mais passagens pertencentes à mesma categoria, ela foi contabilizada apenas uma vez. Isso nos permite observar qual é a frequência que elas aparecem tendo como parâmetro a revista como um todo.

Somando as ocorrências nas três revistas consultadas, poderemos observar a seguinte tabela, correspondente ao período de Janeiro a Dezembro de 2009:

\begin{tabular}{|c|c|c|}
\hline & Total & $\%$ \\
\hline Trajetórias Pessoais & 2072 & $22,6 \%$ \\
\hline Comparativa & 1745 & $19,03 \%$ \\
\hline Comparativa quase-lógica & 1110 & $12,10 \%$ \\
\hline Disjunção & 1187 & $12,95 \%$ \\
\hline Origem & 1641 & $17,9 \%$ \\
\hline Aspas & 1207 & $13,16 \%$ \\
\hline Ditos famosos & 204 & $2,22 \%$ \\
\hline
\end{tabular}


Pelo quadro, podemos perceber que as narrativas de trajetórias pessoais são as mais utilizadas (com 22,6\% das ocorrências), seguidas pelas narrativas de ordem comparativa (com 19,03\%) e pelas de origem (com 17,9\%). As narrativas de disjunção e as quase-lógicas vêm em seguida, com uma porcentagem bastante parecida (em torno de $12 \%)$. Os ditos famosos, embora menos utilizados, tem também uma porcentagem expressiva, compondo aproximadamente $2,22 \%$ dos trechos que contém remissões históricas em nosso corpus.

Essas categorias possuem a seguinte distribuição nas revistas:

\begin{tabular}{|c|c|c|c|c|c|c|c|c|}
\hline & \multicolumn{2}{|c|}{ Veja } & \multicolumn{2}{|c|}{ Época } & \multicolumn{2}{|c|}{ IstoÉ } & \multicolumn{2}{|c|}{ Carta Capital } \\
\hline & Total & $\%$ & Total & $\%$ & Total & $\%$ & Total & $\%$ \\
\hline $\begin{array}{c}\text { Trajetórias } \\
\text { Pessoais }\end{array}$ & 429 & $18,94 \%$ & 578 & $22,68 \%$ & 509 & $26,71 \%$ & 546 & $22,3 \%$ \\
\hline Comparativa & 477 & $21,05 \%$ & 508 & $19,93 \%$ & 317 & $16,64 \%$ & 443 & $18,09 \%$ \\
\hline $\begin{array}{l}\text { Comparativa } \\
\text { quase-lógica }\end{array}$ & 291 & $12,84 \%$ & 326 & $12,79 \%$ & 187 & $9,81 \%$ & 306 & $12,5 \%$ \\
\hline Disjunção & 326 & $14,39 \%$ & 332 & $13,02 \%$ & 223 & $11,7 \%$ & 306 & $12,5 \%$ \\
\hline Origem & 423 & $18,67 \%$ & 409 & $16,05 \%$ & 362 & $19 \%$ & 447 & $18,25 \%$ \\
\hline Aspas & 252 & $11,12 \%$ & 348 & $13,65 \%$ & 280 & $14,69 \%$ & 327 & $13,35 \%$ \\
\hline Ditos famosos & 57 & $2,51 \%$ & 47 & $1,84 \%$ & 27 & $1,41 \%$ & 73 & $2,9 \%$ \\
\hline $\begin{array}{l}\text { Legenda: Total } \\
\%=\text { porcentage } \\
\text { históricas public }\end{array}$ & de & ões hi & en & cates & & & & es \\
\hline
\end{tabular}

Levando-se em consideração as revistas tomadas individualmente, notamos que há uma maior utilização de narrativas de trajetórias pessoais nas revistas IstoÉ, Época e Carta Capital e uma predominância das narrativas de ordem comparativa na revista Veja. Nesta, as narrativas de trajetórias pessoais são a segunda categoria mais utilizada (com 18,94\%). Nas outras revistas, as narrativas de ordem comparativa são a segunda categoria mais utilizada.

Um outro procedimento metodológico necessário, neste sentido, é a observação da forma como se dá a urdidura de enredo, ou seja, a forma como os núcleos se colocam em uma relação de subordinação uns com os outros e como são costurados os elementos narrativos que funcionarão como motivos iniciais, motivos de transição e motivos conclusivos. Conforme já expusemos, a própria forma como se constrói um enredo 
narrativo já determina significações específicas e, a partir dos mesmos elementos, podem-se construir muitas estórias ou muitos roteiros narrativos diferentes.

Depois de identificadas essas constantes narrativas nos textos jornalísticos que possuem remissões históricas, precisamos explorar outros níveis de análise ligados à semantização do fato jornalístico. Isso porque, como bem coloca Barthes, "do mesmo modo que a linguística para na frase, a análise da narrativa para no discurso: é necessário em seguida passar a uma outra semiótica" (BARTHES, 1976: 52). Com o objetivo de identificar os intertextos e os interdiscursos que são mobilizados a partir do jogo de reenvio destas remissões históricas na narrativa jornalística, utilizaremos aportes metodológicos da análise do discurso. Isso porque se trata de uma metodologia que nos permite abarcar tanto as formações discursivas quanto as formações ideológicas presentes nos textos.

Como bem pontuam Greimas e Courtés (1979: 125-126), "numa primeira abordagem, pode-se identificar o conceito de discurso com o de processo semiótico e considerar como pertencente à teoria do discurso a totalidade dos fatos semióticos (relações, unidades, operações, etc.) situados no eixo sintagmático da linguagem". Dentro dessa perspectiva da linguística discursiva, o discurso é sempre o sinônimo de um texto: "de fato, certas línguas europeias, por não possuírem equivalente para a palavra franco-inglesa discurso, foram levadas a substituí-la por texto e a falar de linguística textual" (GREIMAS e COURTÉS, 1979: 126).

Este conceito amplo de discurso, no entanto, é paulatinamente substituído por concepções mais restritas, que buscam delimitar melhor o que seria da competência de uma análise do discurso. Uma destas acepções é posta, por exemplo, a partir de um raciocínio que implica que:

Se a enunciação é, com efeito, segundo Benveniste, a 'colocação em discurso' da língua, então o discurso é justamente o que é colocado pela enunciação: substituindo, nesta definição de Benveniste, o conceito de 'língua' pelo de competência sêmionarrativa, dir-se-á que a colocação em discurso - ou discursivização - consiste na retomada das estruturas sêmio-narrativas e na sua transformação em estruturas discursivas. Dir-se-á também que o discurso é o resultado dessa manipulação das formas profundas, que acarreta um acréscimo de articulações significantes. Delineia-se, assim, uma análise discursiva, distinta da análise da narrativa que a primeira pressupõe (GREIMAS e COURTÉS, 1979: 127).

Sendo a produção de discursos uma "seleção contínua dos possíveis, a qual abre caminho através das redes de coerções" (GREIMAS e COURTÉS, 1979: 130), este passa a ser circunscrito a partir de sua relação com as visões de mundo que podem são articuladas no conjunto das enunciações. Confundindo-se com o próprio ato da língua, o discurso passa a se configurar "como o domínio em que as relações simbólicas são 
tomadas como instituintes do sujeito e das realidades que o situam. Antes do discurso, portanto, não há realidade". Isso significa que "os discursos dados socialmente inserem o sujeito em uma ordem simbólica que o precede e o define, sendo ao mesmo tempo transformada por ele, pois quem diz 'humano' diz, ao mesmo tempo, 'falante', e quem diz 'homem falante' diz, ao mesmo tempo, 'homem social'” (SOARES, 2008)

A partir da acepção, portanto, de que "uma vez que lidamos com um fundo nãorepresentável, e um tecido tramado pela ordem simbólica, somos obrigados a acatar a noção de realidade como construção de mundos" (GOMES, 2003: 65), a noção de análise de discurso adotada aqui remete ao desvelar das condições que formam e que atravessam estes discursos. Isso leva, necessariamente, a uma pesquisa que se dedica "à recuperação, como interdiscurso, de outras formações, às vezes momentâneas, que atingem os discursos, atravessando-os e modificando-os conforme as relações de poder se desenham em um momento" (GOMES, 2008: 15-16).

Para tal empreitada, utilizaremos como conceitos operatórios as noções trazidas pela Teoria das Implicitações, de Oswald Ducrot. Para isso, é necessário entendermos algumas de suas acepções a respeito do funcionamento da língua.

Para Ducrot, a língua não pode ser concebida como um código de comunicação fechado; deve ser entendida tal como um jogo, "ou melhor, como o estabelecimento das regras de um jogo que se confunde com a existência cotidiana". Caso contrário, estaríamos admitindo que "os conteúdos expressos graças a ela são exprimidos de maneira explicita (...) assim, o que é dito no código é totalmente dito, ou não é dito de forma alguma". A realidade da língua abarca, no entanto, o fato de que "muitas vezes temos necessidade de, ao mesmo tempo, dizer certas coisas, e de poder fazer como se não tivéssemos ditos: de dizê-las, mas de tal forma que possamos recusar a responsabilidade de tê-las dito" (DUCROT, 1972: 12-13).

E é desta forma que a linguagem se apresenta como um jogo de remissões entre conteúdos explicitamente postos e outros que estão apenas implícitos. Mais do que isso, todo o conteúdo que é dito carrega consigo uma série de interdiscursos não ditos. Com bem explica Zandwais (1990: 15), "se por um lado a língua pode se representar como

\footnotetext{
${ }^{8}$ Como bem aponta Soares (2008), há um caráter de mediação pressuposto nos discursos que se refere "a seu aspecto de construção do mundo, apontando para a indissociabilidade entre o campo discursivo e o campo social. Entre fatos e relatos, os acontecimentos só passam a ser reconhecidos como realidade por meio de construções narrativas operadas na linguagem, tornando-se realidades discursivas. Nessa construção, pela própria definição de linguagem, algo sempre vai faltar - uma parte impossível de ser simbolizada. Se, por um lado, podemos afirmar não ser possível à linguagem recobrir integralmente um suposto mundo que a antecede, devemos afirmar, por outro, não ser possível à realidade constituir-se enquanto tal a não ser no incessante jogo de proximidade e distanciamento em relação à linguagem, por meio de formações e práticas discursivas".
} 
um objeto atestado e transparente, por outro, pode se constituir num lugar que se configura por ocultamentos, resistência, negligências, camuflagem, ambiguidades, ou, ainda, enfrentamentos".

Um determinado enunciado (E), para Ducrot, quando posto sob o trabalho de um componente linguístico (CL) receberá um sentido (X). Essa não é, porém, a significação final deste enunciado. Ela estará em dependência direta da situação de enunciação (S) e a aplicações de determinados componentes retóricos (CR). Esse mecanismo da língua pode ser posto no seguinte esquema (VOGT, 1989: 12):

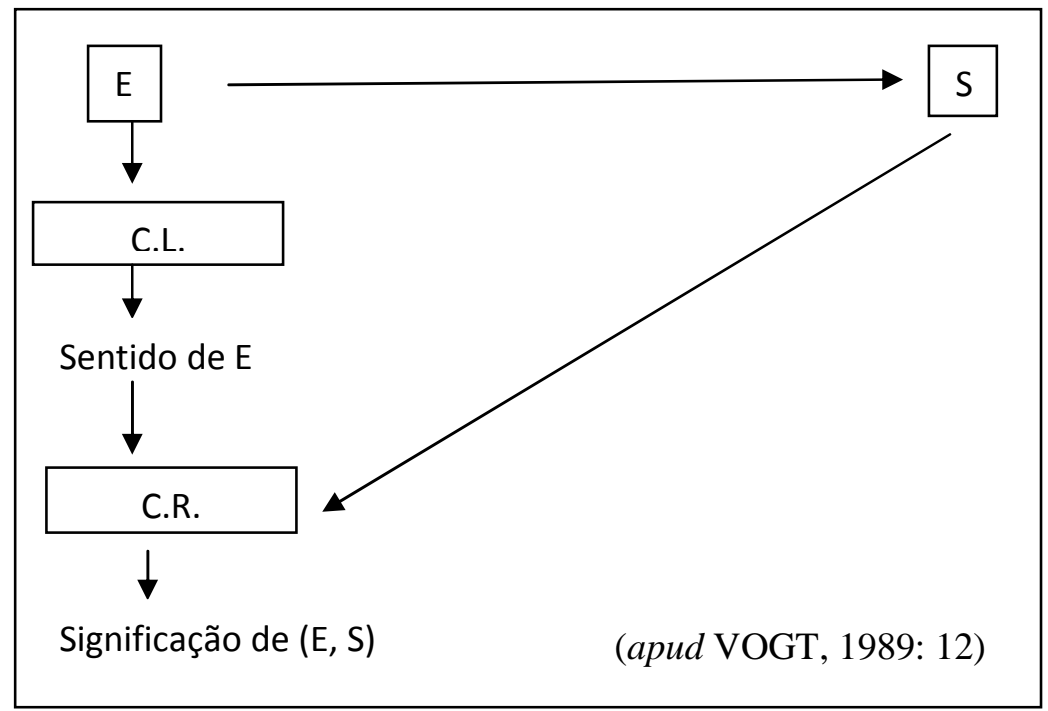

Este esquema tem algumas implicações importantes dentro da análise de Ducrot uma vez que, para este autor "as circunstâncias da enunciação são mobilizadas para explicar o sentido real de uma ocorrência particular de um enunciado, somente depois que uma significação tenha sido atribuída ao próprio enunciado" (DUCROT, 1987: 16).

Para Ducrot, ele está alicerçado no fato de que determinadas significações dos enunciados simplesmente não podem ser ditas em determinadas situações. Desta forma, os componentes retóricos as moldam de maneira que o que é dito representa a forma mais forte que certa enunciação poderia ser posta em dado contexto, formando um sentido que é, em última análise, apenas teórico. Nesta distância entre a significação e o sentido estão os implícitos da linguagem.

Um procedimento comum que atestaria esta existência do implícito estaria, por exemplo, quando para assinalar algum fato, a pessoa se refere à outra coisa em seu lugar, como uma causa ou uma consequência da primeira. "Dizemos que o tempo está bom para fazer entender que vamos sair; falamos do que vimos fora para fazer saber que 
saímos". Isto também pode ser traduzido em um esquema em que o enunciado "X, logo $\mathrm{Y}$ " tem como objetivo mostrar uma terceira proposição $\mathrm{Z}$ e, assim, dizemos "'Fulano veio me ver; logo ele não tem problemas', para dar a entender que a pessoa em questão não poderia vir senão por interesse" (DUCROT, 1972: 15).

Os implícitos da língua, neste sentido, também ser relacionados a um nível mais profundo do discurso e dizem respeito mesmo ao fato de que o ato de tomar a palavra não é nem livre, nem gratuito.

"Não é livre, no sentido em que certas condições devem ser satisfeitas para que se tenha o direito de falar, e de falar desta ou daquela maneira". E, por fim, "não é gratuito, no sentido em que toda a fala deve apresentar-se como motivada, como respondendo a certas necessidades ou visando a certos fins" (DUCROT, 1972: 16).

De acordo com dado exemplo por Carlos Vogt (1989), o funcionamento seria o seguinte para um dado enunciado (1), em duas situações distintas (S1) e (S2):

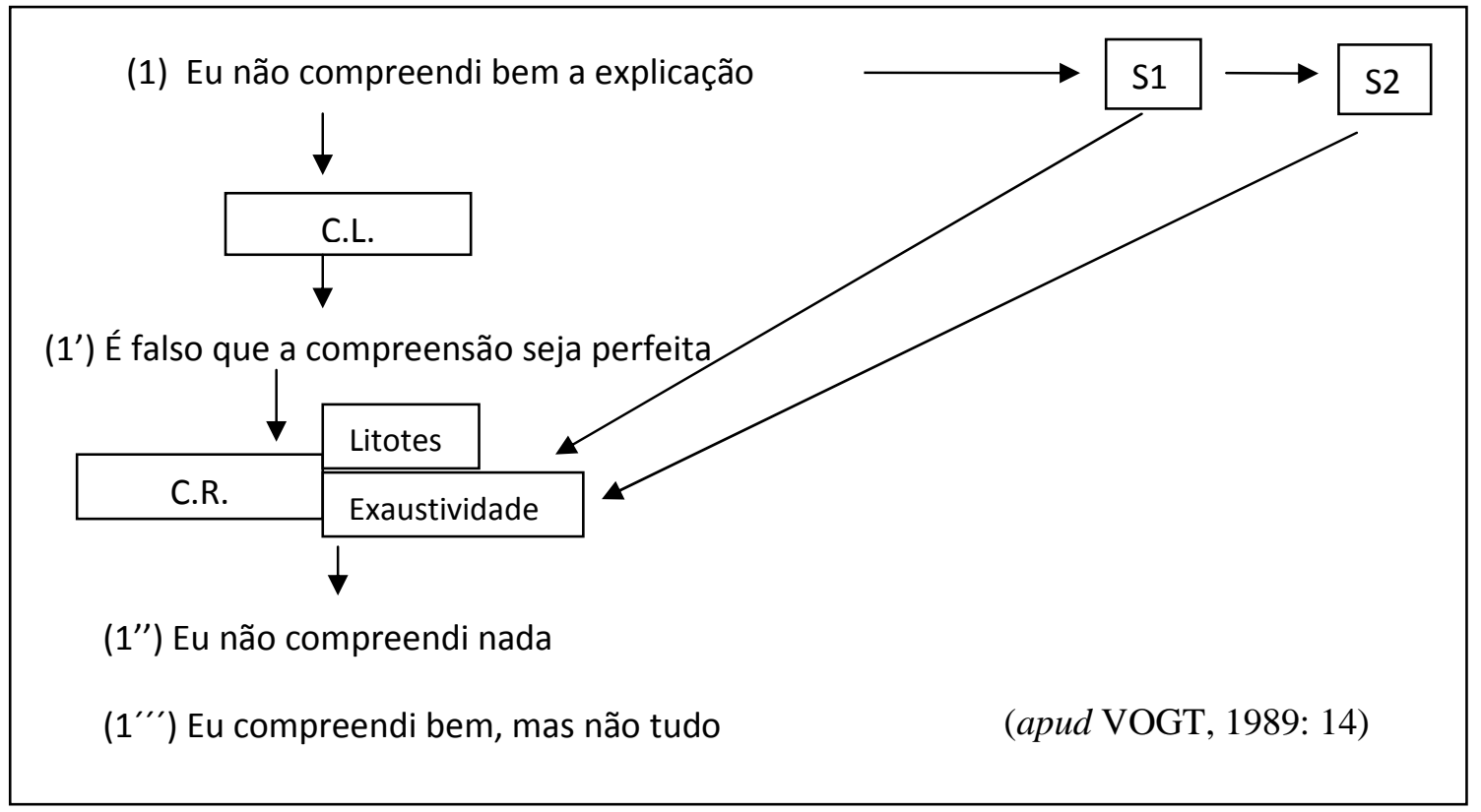

Estes lugares implícitos da língua podem ser estudados a partir dos conceitos operatórios dos pressupostos e dos subentendidos.

Os pressupostos são elementos inscritos nos enunciados (e que carregam marcas linguísticas, como determinados verbos, advérbios e conjunções chamados de "marcadores de pressuposição") que norteiam e delimitam as direções a serem tomadas pelos interlocutores. 
Ou seja, é a plataforma comum (ou elementos que precisam ser inferidos) que permite que determinados enunciados sejam entendidos. Como bem explica Fiorin (2002: 182), trata-se de um recurso argumentativo que aprisiona o leitor dentro de uma determinada lógica do texto criada pelo autor, uma vez que, quando o posto é tido como verdadeiro, o pressuposto também o é - ou seja, o pressuposto é apresentado como evidente e indiscutível. Ou seja, "pressupor não é dizer o que o ouvinte sabe ou o que se pensa que ele sabe ou deveria saber, mas situar o diálogo na hipótese de que ele já soubesse" (DUCROT, 1987: 20).

Do ponto de vista das relações intersubjetivas no discurso, a conceituação de um pressuposto diz respeito, portanto, ao fato de que "a escolha de um enunciado que comporta este ou aquele pressuposto introduz certa modificação nas relações entre os interlocutores". Dentro desta lógica, "pressupor seria, então, um ato de fala com um valor ilocutório, tal como prometer, ordenar, interrrogar" (DUCROT e TODOROV, 2007: 250).

Os subentendidos, por sua vez, não carregam marcas linguísticas inscritas nos enunciados.

Eles estão mais relacionados ao contexto de produção da fala e às possíveis interpretações por parte dos ouvintes. "Enquanto os pressupostos produzem informações já dadas pelos itens gramaticais e lexicais que constituem os enunciados, os subentendidos se constituem em informações novas que podem ser obtidas pelo interlocutor, a partir de um cálculo semântico-discursivo" (ZANDWAIS, 1990: 32).

O subentendido responsabiliza o leitor por determinada interpretação do texto interpretação esta induzida pela própria enunciação. Desta forma, eles devem ser entendidos como "efeitos produzidos, efeitos de sentido como operação de interpretação por parte do espectador e se colocam em dependência direta a situações e condições de enunciação"

É neste sentido que "se o pressuposto é uma condição de formulação do enunciado, o subentendido é uma ilação sobre ele fundada" (GOMES, 2008: 19).

O pressuposto, portanto, como bem coloca Fiorin, é dado como indiscutível tanto para o falante quanto para o ouvinte, enquanto o subentendido é de inteira responsabilidade do ouvinte. Neste último, inclusive, o autor pode se aproveitar do sentido literal da expressão, para negar determinados implícitos de sua fala.

Se retornarmos ao esquema linguístico apresentado por Vogt (1989), em um outro exemplo, a relação entre o posto $(\mathrm{P})$, o pressuposto (PP) e o subtendidos (SB) possíveis em determinadas situações seria a seguinte: 
(2) O povo ainda exige mudanças radicais

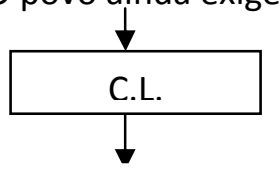

(PP) O povo exigia mudanças radicais

(P) O povo exige mudanças radicais
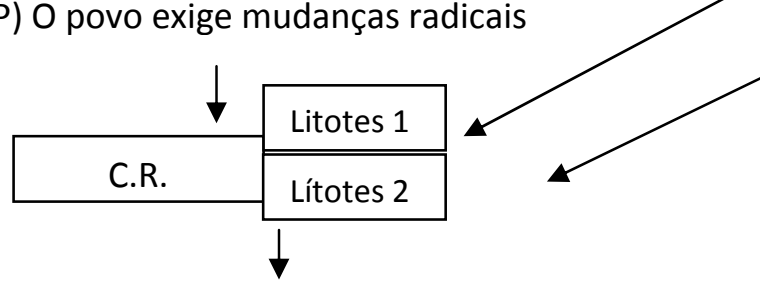

(SB1) A situação está realmente ruim.

(SB2) A situação melhorou realmente.

É a partir destes elementos, que podemos entender como as narrativas históricas existentes nas reportagens mobilizam discursos outros, que se diferenciam daqueles postos quando analisamos somente o nível dos conteúdos explícitos dos textos. Ao citar determinado fato histórico - em detrimento de outros possíveis - o jornalista certamente mobiliza determinados pressupostos e subentendidos que estão alocados sob as narrativas evocadas. Os conceitos operatórios e metodológicos postos pela Teoria das Implicitações, portanto, nos ajudarão a delimitar quais são estes elementos que atravessam os discursos e criam significações.

A metodologia comparativa de origem híbrida proposta para o presente trabalho, portanto, retira seus conceitos operatórios tanto da Análise Estrutural da Narrativa quanto da Teoria das Implicitações, conforme expostos e definidos acima. Com isso, buscaremos abarcar o estudo tanto das constantes narrativas sobre o passado comumente utilizadas pelos jornalistas na construção de suas reportagens; quanto os interdiscursos que são mediados por sua inserção. A partir disso, poderemos visualizar alguns efeitos de sentido envolvidos nas apropriações dos dados históricos pelos jornalistas.

\section{Recorte do corpus}

Conforme já anunciamos, o objeto de estudo deste trabalho é, grosso modo, investigar a forma como os dados históricos, quando inseridos nas narrativas das revistas informativas interpretativas semanais, contribuem para a semantização do acontecimento jornalístico. A expressão "narrativa jornalística" parece prescindir de um 
detalhamento sobre o seu significado - seu uso corrente já absorve o que queremos dizer por isso. Se optarmos por uma definição mais circunscrita, podemos adotar a conceitualização de Sodré e Ferrari (1986: 11), quando colocam que "o desdobramento das clássicas perguntas a que a notícia pretende responder (...) constituirá de pleno direito uma narrativa, não mais regida pelo imaginário, como na literatura de ficção, mas pela realidade factual do dia a dia, pelos pontos rítmicos do cotidiano que, discursivamente trabalhados, tornam-se reportagem".

A outra parte da sentença - "dados históricos" - no entanto, é um elemento que necessita de um pouco mais de cuidado em sua apreensão. Aparentemente, trata-se de uma tarefa simples, uma vez que temos uma experiência diária em diferenciar o que é uma informação histórica do que se configura como um dado do presente. Quando tentamos defini-los conceitualmente, no entanto, uma série de dificuldades surge, uma vez que estes dados vindos do passado são bastante heterogêneos e a própria conceituação de "história" não pode ser dada sem a explicitação de uma série de pressupostos que não raro mudam de acordo com a filiação teórica proposta.

Desta forma, o que se constitui como um dado histórico? Trata-se de qualquer informação que vem do passado? Ou apenas dos grandes eventos que normalmente imputamos um status especial em meio ao devir dos acontecimentos? E mesmo que escolhamos uma das duas opções, qual é então essa linha divisória que deveria separar tudo o que ainda é presente do que já pode ser marcado com a pecha do decorrido (um dia, uma década, um século)?

Embora diversas nuances possam ser traçadas a este respeito, parece haver um consenso de que há uma absoluta impossibilidade de se definir a história pelo seu objeto. E isso porque simplesmente "não há fatos históricos por natureza como existem fatos químicos ou demográficos" (PROST, 2008: 64). Se é que se pode definir algo que se aproxime de um fato histórico, este é sempre construído, é sempre posto por sua posição relativa a um observador.

Já Seignobos apontava para o abandono da posição de que o termo "histórico" deveria ser uma espécie de sinônimo de "algo digno de ser relatado" (tal como usamos em expressões como "um dia histórico" ou "uma palavra histórica"). "Qualquer incidente do passado faz parte da história, tanto o traje usado por um camponês do século XVIII, quanto a Tomada da Bastilha; além disso, os motivos que tornam um fato digno de menção são infinitamente variáveis" (SEIGNOBOS apud PROST, 2008: 65). E é por isso que a história abrangeria potencialmente todos os fatos do passado, tanto os políticos e econômicos, quanto os sociais ou intelectuais. 
Isso tem implicações importantes, uma vez que, em resumo, significa que "não há fatos históricos por sua natureza, mas apenas por sua posição relativamente a um observador. Qualquer fato que já não pode ser observado diretamente, por ter deixado de existir, é histórico. Em vez de ser inerente aos fatos, o caráter histórico limita-se à maneira de conhecê-los" (SEIGNOBOS apud PROST, 2008: 65).

Embora discorde da afirmação de que a "história é a ciência do passado" - na medida em que o próprio passado, enquanto tal, não pode ser objeto da ciência - a visão de Marc Bloch não é menos geral em relação ao que deve ser objeto da história. Ele afirma que "há muito tempo, com efeito, nossos grandes precursores, Michelet, Fustel de Colanges, nos ensinaram a reconhecer: o objeto da história é, por natureza, o homem. Digamos melhor: os homens". E isso porque sempre através dos grandes vestígios - ou seja, dos artefatos ou máquinas, dos escritos ou das instituições - é justamente os homens que o historiador busca capturar através dos rastros. "O historiador se parece com o ogro da lenda. Onde fareja carne humana, sabe que ali está a sua caça" (BLOCH, 2001: 54).

O princípio diferenciador da história em relação a outras ciências humanas estaria posto na formulação de que o historiador não pensa apenas o humano, mas sim, trata-se do estudo dos homens no tempo.

Trata-se de uma visão não muito diferente da de Febvre, quando este coloca que "a história é um meio de organizar o passado para impedi-lo de pesar demais sobre os ombros dos homens". Assim, ela é uma prática que, ao contrário de restringir os objetos do passado que podem ser estudados, os expandem como uma forma de apreendê-lo melhor. Assim, a história "certamente, (...) não se resigna a ignorar, mas esforça-se em aumentar cada vez mais os acervos dos fatos históricos à disposição de nossas civilizações para que estas possam escrever a história" (FEBVRE apud PROST, 2008: 268).

Diante disso, a posição de Paul Veyne sobre este tema nos parece bastante interessante. Segundo o historiador, "é impossível decidir que um fato é histórico e que um outro é uma anedota digna de esquecimento, porque todo o fato entra numa série e só tem importância relativa na sua série" (VEYNE, 1983a: 14). Impõe-se aqui, novamente, a ideia de que este "fato histórico" é sempre uma questão construída artificialmente. Já que, a rigor, tudo é histórico, "é suficiente admitir que (...) a história não é mais do que a resposta às nossas interrogações, porque não podemos materialmente colocar todas as questões, descrever todo o devir, e por que o progresso 
do questionário histórico se situa no tempo e é tão lento como o progresso de qualquer outra ciência" (VEYNE, 1983a: 45).

Devemos adotar como posto, portanto, o ponto de vista de que a marcação sobre o que será considerado um fato histórico em oposição a um fato jornalístico só poderá ser, necessariamente, uma divisão artificial. Diante dessa questão, a maneira de se posicionar é, portanto, com a adoção de um marco - fruto de uma escolha motivada pelas questões propostas pelo pesquisador - para delimitar o que separa a representação do decorrido das mediações sobre eventos recentes ou da atualidade.

Como primeiro procedimento de recorte de corpus, a proposta, para o presente trabalho, é adotarmos o ano de 1995 como uma fronteira demarcatória para o que será considerado como "dado histórico". Certamente existem algumas razões para esta escolha. Ele marca o primeiro ano do mandato de Fernando Henrique Cardoso na presidência - que se tornaria, posteriormente, o primeiro governo brasileiro do século XXI. De qualquer maneira, trata-se mesmo de uma demarcação artificial e, muito embora tenhamos motivos para adotarmos este marco, a escolha de qualquer outro também não deixaria de implicar a possibilidade de adoção de demarcações distintas.

Uma vez definido o que será entendido como "dado histórico", podemos partir para outros recortes de corpus que se fazem necessários.

Conforme já colocamos, as reportagens inicialmente selecionadas - a saber, todas aquelas que possuírem referência a eventos ocorridos antes do ano de 1995 nas quatro revistas citadas (Veja, Época, IstoÉ e Carta Capital) - serão separadas de acordo com as constantes narrativas encontradas a partir da relação entre o dado histórico e a narrativa jornalística mais ampla. Assim, elas serão divididas nas categorias: "narrativas de trajetórias pessoais", "narrativas de ordem comparativa", "narrativas de disjunção" e "narrativas de origem". Os "marcadores de pressuposição" nos ajudarão, neste caso, a delimitar quais matérias figurarão em cada uma delas.

Depois desta triagem inicial, daremos preferência, para uma análise mais detida, às reportagens que foram publicadas a respeito de uma mesma pauta nas quatro revistas analisadas.

Por "texto jornalístico", estamos nos referindo, aqui, a todas as composições textuais que ocupam mais de uma página nas revistas. Assim, serão englobados os editoriais, as colunas opinativas, as matérias e as reportagens. Somente as notas informativas não serão analisadas.

Quanto às entrevistas, será adotado o seguinte procedimento: serão analisados apenas os trechos que foram escritos pelo próprio jornalista. As falas dos entrevistados, 
deste modo, não serão analisadas, mas sim, apenas as perguntas e demais trechos que tenham sido postos pelo entrevistador ou repórter (como perfil do entrevistado ou texto de introdução, por exemplo). Nos demais textos jornalísticos, este critério também será utilizado. Nós não analisaremos as aspas de possíveis entrevistados que citem dados históricos, bem como a citação de livros que tragam esta informação. Eles serão discriminados estatisticamente, mas não servirão como material da análise.

A partir deste recorte inicial, adotaremos como conceitos operatórios de análise, em cada uma das matérias selecionadas, as noções que foram expostas nos procedimentos metodológicos. Assim, poderemos estudar as constantes narrativas através das noções de "urdidura de enredo"; "funções cardinais"; "funções catálises" e "sequências narrativas" e os interdiscursos presentes nos textos a partir dos conceitos de "pressupostos" e "subentendidos".

\section{Especificidades do cruzamento entre a história e o jornalismo}

Para que possamos entender o funcionamento da edificação de lugares de sentido nas narrativas jornalísticas através da remissão à história, no entanto, é necessário discutirmos alguns tópicos preliminarmente. Antes de aplicarmos esta metodologia ao corpus selecionado é necessário discutirmos algumas temáticas que marcam um solo de partida e perpassam algumas características específicas do jornalismo que demarcam algumas diferenças em sua forma de apropriação do passado em relação a outros produtos midiáticos.

Ao contrário de outros conteúdos - tais como o cinema e o romance histórico -, cuja preocupação com os temas da atualidade é normalmente bastante indireta e fragmentada, o jornalismo possui como ponto de partida esta atualidade e a história se insere como um acessório semântico dentro de um quadro de sentidos mais amplo, quando o próprio acontecimento bruto já se configurou enquanto acontecimento jornalístico. É de acordo com esta característica que as remissões ao passado presentes nas narrativas jornalísticas são quase sempre breves, lacunares e esparsas.

Mais do que isso, há uma preocupação fundamental com a referencialidade de seu discurso. Por mais problemática que possa ser esta noção, há sempre uma determinada busca pela objetividade nos relatos dos eventos de forma que a própria narrativa jornalística passa a adotar determinadas estratégias para que este princípio seja confirmado. A apropriação da História deve, portanto, necessariamente refletir essa busca primordial da imprensa que se configura mesmo com uma das metanarrativas que sustentam a prática. 
Há ainda outros fatores que devem ser levados em consideração. Se adotarmos, assim com Habermas (1984), a ideia de que a verdade no espaço público é construída através dos mecanismos da linguagem ou, mais especificamente, que a verdade tem que definir-se, necessariamente, por referência à argumentação, de forma que a objetividade passa a ser uma questão de reconhecimento dentro de dada comunidade, então não podemos ignorar a importância da construção de um comum nas narrativas jornalísticas. Se a instituição por excelência da esfera pública, - entendida com a intermediação, através da opinião pública, entre o Estado e as necessidades sociais - é justamente a imprensa, podemos entender que não é de pouco impacto a remissão a um suposto comum que está embutido nas narrativas históricas ligadas ás memórias coletivas.

É em torno destes aspectos que diferenciam a remissão histórica efetuada pelo jornalismo das dos demais produtos midiáticos que precisamos aprofundar antes de analisar as reportagens propriamente ditas.

Para começar, a própria noção de "acontecimento jornalístico" deve ser melhor delineada. No primeiro capítulo deste trabalho, portanto, discutiremos a questão de que, por mais que o jornalismo seja uma construção imaginária do mundo, ele está sempre sujeito ao fato de se articular em torno de um discurso referencial, com todas as implicações que advém disso.

Assim, muito embora tanto a imprensa quanto a história sejam artefatos verbais que constroem mundos possíveis através da sujeição à narrativa, tratam-se também de dois discursos que tentam camuflar este estatuto o tempo inteiro. Iremos estudar a forma como o jornalismo sempre tenta articular uma ilusão referencial (ligada a ideia de que a linguagem é transparente) e isso afeta de forma decisiva o modo pelo qual ele utiliza as remissões históricas. A partir de determinadas características do discurso histórico como o fato de que ele articula suas próprias ilusões referenciais, bem como o seu estatuto enquanto a fala de um outro e enquanto um discurso constituinte ligado a uma posição de autoridade - iremos estudar a forma a partir da qual, ao evocar a história, a narrativa jornalística invoca uma estratégia referencial.

Outra questão que concerne ao "acontecimento jornalístico" diz respeito à ideia de que a semantização passa necessariamente por uma organização coletiva dos valores. $\mathrm{Ou}$, em outras palavras, diz respeito ao fato de que a produção da notícia é sempre construída através da inscrição do fato jornalístico dentro de uma rede de significações sociais, de modo que o evento sofra um processo de descontextualização do lugar de sua erupção e recontextualização em um conjunto de significados já estabelecidos. 
A partir de um estudo de como o jornalismo interpretativo opera uma construção imaginária do tempo - sendo que as expansões para o passado (origens) e para o futuro (prognósticos) são mesmo suas características diferenciadoras - e uma construção imaginária do comum - sendo que a imprensa se relaciona com o tempo não necessariamente a partir da perspectiva do que é atual, mas a partir de algo que é repetidamente posto como inédito dentro de um universo de discursos - o segundo capítulo irá discutir a forma como a história contribui para o reforço destas características. Em outras palavras, investigaremos o que pode a história nos dizer acerca do comum, do presente e do futuro e, a partir disso, estudaremos como, ao evocar a história, a narrativa jornalística invoca uma construção do tempo e uma construção do comum.

Depois destas investigações de ordem geral, os próximos capítulos irão se concentrar na análise do corpus recolhido propriamente dito, de acordo com a metodologia descrita, para que possamos, enfim, estudar como as remissões históricas atuam como estratégias de semantização do fato jornalístico. Assim, no capítulo III, estudaremos as funções e sequências narrativas de origem. No capítulo IV, iremos analisar as funções e sequências de ordem comparativa (incluindo as quase-lógicas) e as de disjunção. Por fim, no capítulo $\mathrm{V}$, a atenção será voltada para as narrativas de origem.

$\mathrm{Na}$ edição 606, a última do ano de 2009, publicada pela revista Época, o editorial fazia um balanço do último século nos seguintes termos: "O que define uma década? Os anos 20 foram de loucura e desvario, a Era do Jazz. Nos anos 30, o mundo assistiu atônito aos efeitos da crise de 29 e à ascensão do fascismo, do nazismo e do stalinismo". Também “nos anos 90, a globalização se impôs no planeta, a internet saiu dos laboratórios para as ruas - e a hegemonia americana atingiu seu auge. E a década que se acaba agora, como será definida?" (GUROVITZ, 28/12/2009: 6).

Depois de fazer uma série de considerações a respeito dos anos 2000, o texto concluía que "a próxima década deixará claro se saberemos aproveitar a oportunidade gigantesca que se abriu para nós neste novo mundo" (GUROVITZ, 28/12/2009: 6).

Definir um sentido para o passado que abre uma possibilidade de entendimento para o presente e uma promessa de um prognóstico para o futuro parece mesmo uma obsessão jornalística. E assim como naquele editorial de 1808, esse texto mostra que a missão do jornalismo ainda parece estar edificada em se referir às memórias do tempo e em preconizar as consequências dos fatos. 


\section{CAPÍTULO I}

\section{O JORNALISMO E A HISTÓRIA COMO DISCURSOS REFERENCIAIS}

A VONTADE DE REAL NAS CONSTRUÇÕES IMAGINÁRIAS DO MUNDO

Para Adriano Duarte Rodrigues (1990), a notícia deve ser entendida como um meta-acontecimento discursivo ou, em outras palavras, como "uma espécie de acontecimento segundo, provocado pela própria existência do discurso jornalístico". Sendo o acontecimento aquilo que "irrompe acidentalmente à superfície dos corpos como reflexo inesperado, como efeito sem causa, como puro atributo", o sufixo "meta" da expressão - que significa "para além de" (BERNARDO, 2010: 10) - escancara o fato de que o acontecimento jornalístico sempre será uma espécie de redescrição, de forma que, ao divulgar o fato, sempre se acaba criando um outro na própria tessitura da narrativa.

A partir da noção de que, ao narrar, a notícia constrói mundos (GOMES, 2003), o acontecimento jornalístico poderia ser posto mesmo como um conjunto de "artefatos linguísticos que procuram representar determinados aspectos da realidade e resultam de um processo de produção e fabrico onde interagem diversos fatores" (SOUSA, 2002: 13).

Esta noção de que o jornalismo se estrutura enquanto discurso e enquanto narrativa e que, exatamente por estar imerso na produção linguageira, diz sempre respeito a uma construção (que de modo algum se mistura com o real), é trabalhada por muitos autores. É neste sentido que Verón (1995: II) coloca que "os acontecimentos sociais não são objetos que se encontram já feitos em alguma parte da realidade e cujas propriedades e transformações nos são dados a conhecer de imediato pelos meios com maior ou menor fidelidade. Eles só existem na medida em que esses meios o elaboram".

Algo bastante parecido com isso também é dito a respeito das representações da História. Hayden White, por exemplo, parte da noção de que também o passado só pode ser apreendido através das estruturas da narrativa e do discurso. Para este autor, dificilmente poderíamos pensar a representação historiadora tal como àquela que pode ser posta pela metáfora de uma maquete de um avião, de um mapa ou de uma fotografia. Isso porque é errôneo pensar que podemos verificar a adequação do modelo ao referente olhando para o original e aplicando algumas regras necessárias de tradução.

As narrativas históricas, para White, acabam por representar algo para além de sua mera adequação á veracidade de um acontecimento decorrido. Elas "não são apenas modelos de acontecimentos e processos passados, mas também afirmações metafóricas 
que sugerem uma relação de similitude entre esses acontecimentos e processos e os tipos de estória que convencionalmente utilizamos para conferir aos acontecimentos de nossas vidas significados culturalmente sancionados" (WHITE, 1994: 105). Isso implica dizer que as narrativas históricas não dizem respeito apenas a uma reprodução de acontecimentos, mas sim, a uma construção que envolve tanto o historiador quanto os códigos socialmente compartilhados. E isso remete à noção de que as narrativas históricas também não são mais do que artefatos verbais.

As fronteiras entre narrativas ficcionais e históricas são esfumaçadas por White a partir da noção de que "a distinção mais antiga entre ficção e história, na qual a ficção é concebida como a representação do imaginável e a história como a representação do verdadeiro, deve dar lugar ao reconhecimento de que só podemos conhecer o real comparando-o ou equiparando-o ao imaginável" (WHITE, 1994: 115).

A sujeição à narrativa e a estruturação enquanto discurso, no entanto, não são as únicas características a serem compartilhadas tanto pelo jornalismo quanto pela história. Muito embora ambos sejam artefatos discursivos, a outra característica que une essas duas formas de construção de mundo é justamente uma constante e renitente tentativa de negação deste estatuto. Enquanto o jornalismo tenta se refugiar em noções vagas de objetividade, neutralidade e transparência, a História também faz uso alguns artifícios para, se remetermos aos termos de Barthes, se revestir dos privilégios do aconteceu. Tanto o discurso da História quanto o discurso do jornalismo, portanto, tentam criar uma ilusão de correspondência imediata entre o acontecimento e a representação, de forma que a última possa se confundir com o próprio real.

Ao descrever essa característica, Itzhak Roeh (apud TRAQUINA, 2005b: 17) coloca que "o fenômeno mais impressionante no jornalismo ocidental, tanto na práxis como na teoria, é a fé metafísica obstinada e conservadora de que a linguagem é transparente". Assim, “o erro assenta na recusa dos jornalistas (...) em situar a profissão onde esta pertence, isto é, no contexto de expressão humana da atividade expressiva. É a recusa de lidar com a escrita das notícias por aquilo que é na essência - contar "estórias"”.

Partindo dessas perspectivas, o objetivo do presente capítulo é, justamente, discutir esse impasse. É estudar como os discursos referenciais lidam com a questão de que "não há uma verdade (para os filósofos, uma questão de fundo teórico) e ainda assim deve-se buscá-la (para os jornalistas, uma questão de fundo prático)" (RESENDE, 2005: 9). 
Procuraremos discutir a forma como se constroem os discursos jornalísticos e históricos, tomando-os como construções imaginárias do mundo que se apoiam em discursos referenciais. Procuraremos explorar autores que trabalharam com esta questão, mostrando, de um lado, como tanto o jornalismo quanto a história são artefatos verbais que constroem determinadas visões de mundo e, de outro, como eles buscam estratégias para camuflar esta condição e se construírem como reconstituições verossímeis dos eventos.

A partir disso, poderemos aprofundar a questão sobre a obsessão jornalística em articular a ilusão de que a linguagem é transparente e mostrar que a sua representação é o real. Investigaremos a forma como - apesar do intenso debate entre historiadores que colocou as representações do passado em seu lugar enquanto produto da linguagem e das formas pelas quais o homem imprime sentido ao mundo - o jornalismo parece olhar a história a partir de um ponto de vista distinto, olhar este também embebido em uma ilusão referencial. Discutiremos como o recorrente recurso dos jornalistas ao discurso histórico parece funcionar como uma estratégia que reforça ou incrementa a "referencialidade" do discurso jornalístico, como, se a partir desta evocação do passado, o jornalismo também pudesse se revestir destes privilégios do aconteceu.

Em suma, discutiremos como ao invocar a História, o jornalismo tenta evocar uma estratégia referencial.

\section{História e Jornalismo como artefatos verbais: a construção de mundos possíveis a partir da sujeição à narrativa}

A noção de acontecimento jornalístico, como já havíamos posto, tem em sua própria conceituação a ideia de que ele se realiza a partir de um processo duplo que envolve, ao mesmo tempo, transformação e transação. Como explica Charaudeau (2006: 114), se o mundo a descrever é o lugar onde se encontra o acontecimento bruto (ou o ponto zero da significação, como coloca Rodrigues), o processo de transformação "consiste, para a instância midiática, em fazer passar o acontecimento de um estado bruto (mas já interpretado), ao estado do mundo midiático construído, isto é, de "notícia'". Este processo acontece sempre sujeito a um processo de transação relacionado à instância receptora, de forma que a notícia é construída tomando um determinado público como referência que, por sua vez, também reinterpreta o texto à sua maneira.

Essas passagens só podem ser feitas, necessariamente, através da transformação do fato bruto em estória, de forma que se constitua uma narrativa. Desta maneira, como 
coloca Soares (2001: 43), "a notícia não é tratada como simples informação, devendo obedecer aos princípios de objetividade, imparcialidade, neutralidade. Antes, é vista como um 'produto cultural' e uma narrativa, implicando a existência de um jornalistanarrador que conta histórias a um suposto leitor-destinatário".

Uma vez que o jornalismo não pode nunca ser separado da construção de uma escrita - entendida, aqui, como uma organização de significantes em torno de um evento que conduz da prática ao texto (CERTEAU, 2008) - os artefatos jornalísticos estão mesmo sujeitos a uma determinada estruturação do discurso. Como coloca Certeau, a produção de textos sempre parte de uma combinação bastante específica entre uma semantização - ou a "edificação de um lugar de sentidos" - e uma seleção, de forma que possa ser ordenada uma inteligibilidade por meio de uma normatividade.

É por esta característica definidora que o processo informativo-jornalístico sempre remete a um jogo entre a descontextualização de um evento do espaço em que ele é produzido em direção a uma recontextualização a partir de determinadas formas expressivas pré-determinadas. É a isso que Sodré (2009: 71) se refere quando coloca que "à emergência da ocorrência ou fato em bruto, segue-se a busca social de sentido para ela e, finalmente, a sua neutralização explicativa pela narrativa do acontecimento". E assim, ao dotar o evento de determinados sentidos socialmente pré-determinados que, ao narrar também explicam uma situação e impõe uma ordem à irrupção do inesperado, que "a narrativa noticiosa restaura uma falha e confirma a previsibilidade da ordem por meio da inscrição do ocorrido na causalidade do fato social".

Há, portanto, um afastamento radical entre o acontecimento em seu estado bruto e o acontecimento jornalístico, na medida em que este passa por um processo de semantização que implica a sujeição a uma determinada estrutura de discurso.

As representações do decorrido trazidas pela História também possuem, igualmente, algumas problematizações neste sentido, na medida em que os fatos do passado também não são inteligíveis fora das estruturas discursivas. Trata-se de um ponto de vista amplamente aceito e mesmo um historiador bastante tradicional como Edward Hallet Carr (2002: 47) afirma que "é comum dizer que os fatos falam por si. Naturalmente isso não é verdade. Os fatos falam apenas quando o historiador os aborda: é ele quem decide quais os fatos que vêm à cena, e em que ordem ou contexto". Para o autor, o status de um determinado acontecimento enquanto acontecimento histórico dependerá sempre de um problema de interpretação.

E é neste sentido que, embora seja bastante comum a utilização da metáfora da montagem de um quebra-cabeça para representar o trabalho do historiador, essa imagem 
é bastante infiel para os problemas do trabalho histórico. A problemática da reconstituição do decorrido não está tanto ligado a lacunas que precisam ser preenchidas, mas sim, a questões mais vastas ligadas a um conjunto de camadas de prédeterminações de sentido que foram sendo construídas ao longo do tempo. Assim, "a história que nós lemos (...) embora baseada em fatos, não é, para dizer a verdade, absolutamente factual, mas uma série de julgamentos aceitos" (CARR, 2002: 50).

A noção de que tanto o jornalismo quanto a história estão submetidos às inscrições discursivas e aos percursos narrativos problematizam uma série de questões em torno dessas práticas. Problematiza, principalmente, a correspondência entre a representação e o referente, de modo que nega mesmo as ilusões referenciais em torno das quais essas práticas se estruturam.

Isso pode ser visto a partir de uma série de aspectos.

Com a finalidade de responder o que é fictício nas representações realistas do mundo e o que é realista nas representações manifestamente fictícias, White recorre às distinções entre signo, símbolo e ícone de Pierce, como forma de alinhavar a narrativa histórica à construção de seus sentidos. Sendo entendidas como estruturas simbólicas tais como metáforas de longo alcance - e não como signos inequívocos dos acontecimentos - as narrativas realistas (como o jornalismo ou a história) trazem a mente uma série de relações que apenas indicam.

O exemplo de White é bastante elucidador a respeito do mecanismo que ele descreve. A frase "meu amor, uma rosa" não pretende, de forma alguma, sugerir que "a pessoa amada é vermelha, amarela, laranja ou escura, que é uma planta, tem espinhos, necessita da luz do sol, deveria ser borrifada regularmente com inseticidas e assim por diante" (WHITE, 1994: 108). O que ela faz é aproximar determinadas qualidades simbolizadas pela rosa e sancionadas nos usos cotidianos da língua - tal como o ato cultural de associar pessoas queridas a rosas - e fornecer diretrizes para um determinado conjunto de imagens que se pretende associar.

Ou seja, "funciona como um símbolo e não como um signo: vale dizer, ela não nos fornece uma descrição ou um ícone da coisa que representa, porém nos diz que imagens procurar em nossa experiência culturalmente codificada a fim de determinar de que modo nos devemos sentir em relação à coisa representada" (WHITE, 1994: 108).

Esse exemplo aparentemente banal traz uma série de implicações importantes se pensarmos, como White, que este mecanismo é o mesmo das narrativas com pretensões realistas em geral. Para dar sentido aos dados que coleta, o narrador seria forçosamente levado a explorar as similaridades metafóricas entre os conjuntos de acontecimentos 
reais e as estruturas de ficção. E embora estes tipos específicos de narradores talvez não gostem de se ver desta maneira, para White, suas obras poderiam ser pensadas como "traduções do fato em ficções", sendo este, de fato, um dos efeitos de suas obras.

Assim, muito embora essa insistência sobre o elemento ficcional de todas as narrativas (inclusive as históricas e jornalísticas) possa despertar um desconforto nos autores que se definem justamente por estarem ocupados com acontecimentos "reais" (em oposição aos ficcionistas que se ocupariam com eventos "imaginados"), o modo como esses dois profissionais dão sentido ao mundo não são essencialmente diferentes. "Na realidade, a história - o mundo real ao longo de sua evolução no tempo - adquire sentido da mesma forma que o poeta e o romancista tentam provê-lo de sentido, isto é, conferindo ao que originariamente se afigura problemático e obscuro o aspecto de uma forma reconhecível, porque familiar". E, desta forma, "não importa se o mundo é concebido como real ou apenas imaginado; a maneira de dar-lhe um sentido é a mesma" (WHITE, 1994: 115).

O fato, neste tipo de narrativa, é sempre construído a partir de uma combinação complexa entre os elementos que foram coletados e os aportes do imaginário constituído. Muniz Sodré (2009: 74) enfatiza este aspecto no jornalismo quando coloca que, para um evento virar notícia, não é tão importante o aspecto "novidadeiro" que ele apresenta, mas sim, o quanto esse acontecimento é marcado no imaginário. "Para nós, o verdadeiro traço em comum entre o homem que morde o pitbull, o pitbull que morde o homem, a chegada de uma delegação do país e o assassinato de Kennedy é a marcação (semiótica, cultural) do fato". O termo "marcado", portanto, neste contexto, diz respeito mesmo aos eventos que são suporte de uma grande carga de valoração simbólica.

Vista sob este ponto de vista, as narrativas jornalísticas também se configuram enquanto metáforas de longo alcance, na medida em que remetem a essas marcações do imaginário.

A partir da mesma noção de White de que as representações realistas não podem ser entendidas senão através das malhas do discurso, Paul Veyne busca um novo entendimento em torno do tema da verdade nestes tipos de estórias. Para ele, se a história é a narrativa dos acontecimentos e como todo o restante decorre deste fato, por conseguinte, "a história é a narrativa de acontecimentos verdadeiros. Nos termos dessa definição, um fato deve preencher uma só condição para ter a dignidade da história: ter acontecido realmente" (VEYNE, 1983a: 35).

Esse ter acontecido realmente, no entanto, estaria sujeito a uma limitação importante. Isso porque o historiador é entendido como um contador de intrigas (na 
medida em que o campo acontecimental nunca pode ser completamente recoberto por suas formulações) e, neste sentido, o tecido da história seria apenas "uma mistura muito humana e muito pouco 'científica' de causas materiais, de fins e de acasos; numa palavra, uma fatia da vida, que o historiador recorta a seu bel-prazer e onde os fatos têm as suas ligações objetivas e a sua importância relativa". Além disso, "a palavra intriga tem a vantagem de lembrar que aquilo que o historiador estuda é tão humano quanto um drama ou um romance" (VEYNE, 1983a: 48). A implicação disso está na constatação de que o acontecimento descrito pelo historiador nunca tem uma existência ontológica, mas sim, se configura como apenas um cruzamento de inúmeros itinerários possíveis que são desvelados na narrativa ${ }^{9}$.

Seguindo o raciocínio de Veyne de que a história pode ser vista tal como um romance, mas acrescida da observação de que se trata de um romance verdadeiro, a própria noção do que implica esse "verdadeiro" passa por uma reformulação radical. Para Veyne, esse questionamento conduz ao enfraquecimento da noção de que a história possa representar uma verdade única e que a maneira singular de o historiador remeter a uma veridicidade é a partir da fragmentação de seu campo. Neste sentido, só é possível fazer histórias parciais. Como a inteligibilidade histórica não pode ser separada da formação da intriga, a sua veracidade também é sempre condicionada a um enredo ${ }^{10}$.

Para explicar essa ideia, Veyne recorre a uma metáfora cartográfica. Neste sentido, a construção das narrativas históricas não seria essencialmente diferente da construção de itinerários através de um mapa: a partir de pontos previamente selecionados, podem-se construir diversos caminhos ou roteiros possíveis. Isso quer dizer que o verdadeiro posto na famosa frase de Veyne está sempre submetido ao tipo de itinerário narrativo que é construído quando se conta uma estória. E desta forma, o número de verdadeiros possíveis é igual ao número de itinerários ou de enredos que podem ser construídos a partir do conjunto dos fatos coletados.

\footnotetext{
${ }^{9}$ Em uma outra formulação, Veyne é ainda mais claro a respeito deste assunto quando ele afirma que "o itinerário que o historiador escolhe para descrever o campo acontecimental pode ser livremente escolhido e todos os itinerários são igualmente legítimos (ainda que não sejam igualmente interessantes). É evidente que é impossível descrever a totalidade do devir e é preciso escolher; também não existe uma categoria particular de acontecimentos (a história política, por exemplo) que seria a história e se imporia à nossa escolha. É, portanto, literalmente verdade afirmar, como Marrou, que toda a historicidade é subjetiva" (VEYNE, 1983a: 53).

${ }^{10}$ Como bem explica Antoine Prost, a visão de Veyne remete ao fato de que embora "a argumentação do enredo esteja baseada em provas, o fato de que a história utilize múltiplos dispositivos de demonstração, [isso] é insuficiente para superar essa dificuldade: as verdades permanecem parciais. Isso implica que elas não possam se acumular. Portanto, o historiador será obrigado a renunciar ao sonho - que continua acalentado, diga ele o que disser - de um saber aproximadamente cumulativo, do mesmo modo que os geógrafos ficam na expectativa de que a colagem dos mapas, de diversas regiões, reduzidos à mesma escala, venham a constituir um mapa mais abrangente" (PROST, 2008: 233).
} 
É a construção de enredo que se torna o ato fundador dos discursos referenciais e, além de recortar o seu objeto especial, é ela também que constitui os fatos como tais. Isso implica dizer que, além da atestada impossibilidade de o historiador construir um quadro completo tal como um mapa na medida em que pode indicar apenas itinerários possíveis, é necessário acrescentar que as próprias escalas deste mapa também estão sujeitas a este trabalho de construção. A própria configuração de enredo já implica, portanto, uma explicação e uma forma específica de argumentação.

O mesmo funcionamento que Veyne atribui à verdade nas narrativas históricas pode ser muito facilmente aplicado às narrativas jornalísticas. Já nos referimos ao fato de que uma congerie de eventos "descobertos" não forma propriamente uma história, mas sim, fornece apenas a matéria-prima para a formação de uma narrativa - que se constituirá enquanto tal quando estes elementos forem postos em relação.

Um mesmo conjunto de eventos do tempo presente pode ser contado de inúmeras formas - como já está posto na noção de urdidura de enredo - formando itinerários narrativos bastante diferentes entre si e todos igualmente ligados a noções imaginárias de verificabilidade. Entre os elementos que são "descobertos" na pesquisa jornalística, há toda uma montagem "inventada" que forma a estória que será contada. Podemos dizer, portanto, que a noção de verdade no jornalismo também diz respeito a estes itinerários narrativos.

Isso pode ser muito facilmente verificado quando comparamos os tratamentos que são dados a uma mesma pauta publicada em dois jornais diferentes. A diferença de posicionamento entre as publicações, muitas vezes, não diz respeito à descoberta de fatos diferenciados ou à consulta a fontes diversas ou à diferença de erudição dos repórteres: diz respeito mesmo aos itinerários narrativos que são construídos.

Trata-se de um tema também trabalhado por Certeau (2008) que, no entanto, aprofunda a questão ao colocar um elemento a mais nesta equação: além do fato de que a própria montagem narrativa já imprime sentidos, temos que levar em consideração também o fato de que a semantização do evento trabalha a partir de regras lógicas ligadas a silogismos. Ou seja, não é a mera mudança na seriação que produz efeitos de sentido diferenciados, mas o elemento intrinsecamente lógico-argumentativo presente nestas narrativas. Explicaremos melhor.

Para Certeau, a transformação da pesquisa empírica em texto comporta dois movimentos de escrita que obedecem, em muitos aspectos, fluxos contraditórios. Isso porque, de um lado, há o imperativo de uma cronologização que alinha os elementos encontrados a partir de certa linearidade $(A, B, C, D, \ldots)$. A expansão desta narrativa pode 
mesmo ser exposta, de modo parecido com o que postula Veyne, a partir de certas reorganizações, omissões e inversões que produzem determinados efeitos de sentido, sendo que podemos organizar a narrativa em uma forma do tipo E,C,A,B,..., etc.

De outro lado, no entanto, a narrativa tem que comportar também, além do imperativo da cronologização ligado à narrativa, o imperativo da semantização, que subverte este caráter ligado meramente à sucessividade e disfarça a explicação do evento com um caráter entimemático. Em outras palavras, as narrativas com pretensões realistas também comportam os elementos do discurso lógico, de forma que a verificabilidade atribuível aos seus enunciados se estrutura a partir de uma série de silogismos.

"Ele, o discurso histórico, pretende dar um conteúdo verdadeiro (que vem da verificabilidade), mas sob a forma de uma narração" (CERTEAU, 2008: 100). E assim, "deporta a causalidade para a sucessividade (post hoc, ergo propter hoc), representa relações de coexistência como relações de coerência, etc." e, desta forma, "a plausibilidade dos enunciados se substitui constantemente à sua vericabilidade" (CERTEAU, 2008: 101).

O movimento das construções das estórias jornalísticas é análogo. Além da seriação narrativa montada a partir de imperativos da narratividade, séries de efeitos de sentido diferentes são, em um mesmo movimento, mobilizados a partir de relações de montagem silogísticas.

Como coloca Karam (2004: 106-107) "no discurso jornalístico, dada a especificidade da linguagem e a enorme gama dos destinatários da informação, pode-se dizer que a persuasão e o convencimento caminham juntos em grande parte das ocasiões". E, neste sentido, "no setor jornalístico (...) pode-se dizer que a lógica é utilizada no próprio campo retórico, em que se recorre ao silogismo para extrair deduções convincentes e demonstráveis, embora não se mostrem todos os dados, todos os possíveis efeitos".

Isso posto, podemos entender um outro aspecto de porque a história e o jornalismo se apresentam enquanto reconstruções de mundo, metáforas de longo alcance. Ligadas aos mecanismos de aferição de sentido do homem às coisas, elas comportam elementos discursivos, imaginários, narrativos e retóricos.

Dentro deste quadro é que Paul Ricoeur coloca que todo ato narrativo está sempre sujeito a noção de intriga, ao combinar os elementos narrativos com as formas sociais pré-estabelecidas a partir das quais dotamos o mundo de sentido. E isso porque, para este autor, "o tempo torna-se tempo humano na medida em que está articulado de 
modo narrativo; em compensação, a narrativa é significativa na medida em que esboça os traços da experiência temporal" (RICOEUR, 1994:15). E isso significa que a experiência narrativa está sempre sujeita a um movimento duplo que estabelece que, de um lado, é a narrativa que humaniza o tempo; e de outro, como uma contrapartida, a noção de que é o tempo que fornece as suas premissas de inteligibilidade. E assim, "compor a intriga já é fazer surgir o inteligível do acidental, o universal do singular, o necessário ou o verossímil do episódico" (RICOEUR, 1994:70).

E, neste movimento, ao seguir uma narrativa, "seguimos, pois, o destino de um tempo prefigurado em um tempo refigurado, pela mediação de um tempo configurado" (RICOEUR, 1994:87). Em outras palavras:

\begin{abstract}
Qualquer que possa ser a força de inovação da composição poética no campo de nossa experiência temporal, a composição da intriga está enraizada numa pré-compreensão do mundo e da ação: de suas estruturas inteligíveis, de suas fontes simbólicas e de seu caráter temporal. (...) Primeiro, se é verdade que a intriga é uma imitação da ação, é exigida uma competência preliminar: a capacidade de identificar a ação em geral por seus traços estruturais; uma semântica da ação explicita esta primeira competência. Ademais, se imitar é elaborar uma significação articulada da ação, é exigida uma competência suplementar: a aptidão de identificar o que chamo de as mediações simbólicas da ação, num sentido da palavra símbolo que Cassirer tornou clássico e que a Antropologia cultural adotou (RICOEUR, 1994: 88)
\end{abstract}

Uma vez que o movimento da tessitura da intriga abarca significados préexistentes à própria configuração narrativa, essas características do narrado encontram uma problemática própria quando alocadas em representações do mundo com objetivos realistas, ou, em outras palavras, em representações como a história e o jornalismo cuja referência empírica são os eventos que realmente aconteceram.

A busca pelo referencial deste tipo de representação imagética do mundo só pode ser compreendido adequadamente, para Ricouer, se tivermos em mente a noção de representância: "a palavra 'representância' condensa em si mesma todas as expectativas, todas as exigências e todas as aporias ligadas a isto que chamamos, de outra maneira, a intenção ou intencionalidade do historiador: ela designa a expectativa ligada ao conhecimento histórico de construções constituindo reconstruções do curso passado dos eventos" (RICOEUR, 2007: 359).

A representância está ligada diretamente ao acordo tácito que existe entre o narrador e o leitor de que aqueles acontecimentos são verdadeiros e não uma mera ficção. Ela marca uma incompletude fundante entre o desejo de se dizer a verdade e a impossibilidade deste alcance. Diz respeito mesmo às matrizes de verdade presumida que, apesar do fato de serem também estruturas imaginárias, tentam garantir uma legitimidade daquilo que está sendo posto. 
Embora esteja de acordo com a noção de que "a história não poderia romper todo laço com a narrativa sem perder seu caráter histórico", para Ricoeur (1994: 255), este laço está atado de uma maneira bastante específica, sempre um tanto indireta e marcada por rupturas com a noção de narrativa tradicional, mas que não pode ser totalmente apartada do processo de inteligibilidade histórica.

Para Ricoeur, o modo de desvelar os fatos, as estruturas e os acontecimentos típico da história se afasta da competência tradicional em se seguir uma narrativa clássica ou ficcional em três pontos que marcam uma ruptura epistemológica. $O$ primeiro deles está relacionado ao fato de que na narrativa tradicional, as conexões explicativas permanecem imanentes à tessitura de intriga; ao passo que a história destaca o processo de explicação do desenrolar dos fatos e a erige como uma problemática distinta.

Além disso, quaisquer que sejam os problemas e os limites envolvidos na noção de objetividade em história, o fato é que há um problema de objetividade em história que está ausente na narrativa tradicional. Isso significa que é "precisamente porque a história tem um projeto de objetividade" que "ela pode colocar um problema específico, o dos limites da objetividade. (...) O historiador dirige-se a um leitor desconfiado, que espera dele não somente que narre, mas que autentifique sua narrativa" (RICOEUR, 1994: 253)

Se, de uma maneira geral, parece ser comumente aceito o fato de que uma coisa é uma narrativa histórica e outra coisa é um romance (mesmo que com claras pretensões realistas), precisamos pensar em qual seria o elemento irredutível a partir do qual essas duas noções poderiam ser separadas. Para Ricoeur (2007: 274), essas duas coisas “distinguem-se pela natureza do pacto implícito ocorrido entre o escritor e seu leitor. Embora informulado, esse pacto estrutura expectativas diferentes, por parte do leitor, e promessas diferentes, por parte do autor". Assim, se um leitor de ficção pode facilmente suspender de bom grado a sua credulidade e não se importar se a narrativa que destrincha aconteceu de fato ou não; ao ler um livro de história o seu olhar crítico se torna vigilante e espera, ao menos, um discurso plausível e admissível. Trata-se do fato, como coloca Louis Mink (apud BANN, 1994: 83), de que se aprende "como distinguir entre ficção e história fazendo diferentes reivindicações de verdade para suas descrições individuais".

Isso sugere, portanto, que "irrealidade e realidade são tidas como modalidades referenciais heterogêneas; a intencionalidade histórica implica que as construções do historiador tenham a ambição de serem reconstruções mais ou menos aproximadas 
daquilo que um dia foi 'real', quaisquer que sejam as dificuldades (...) da representância" (RICOEUR, 2007: 275).

Por fim, enquanto na narrativa tradicional as ações estão sempre relacionadas a agentes determinados que podemos identificar (agentes cuja designação com um nome próprio é possível), a história põe no lugar do sujeito da ação entidades anônimas. Trata-se de uma ruptura significativa à medida que, vista desta maneira, a história parece prescindir de personagens e, sem este elemento fundamental, ela não pode permanecer uma narrativa.

Essas rupturas, no entanto, não indicam, de maneira alguma, que a história não esteja atada à narrativa. Significam, apenas, que este laço não pode ser direto e que estas narrativas resultantes não se misturam aos gêneros ficcionais. Embora digam respeito à exigência de uma nova forma dialética entre a investigação histórica e a competência narrativa, há ainda a reafirmação de um laço que garante que a história não perca seu caráter histórico. Como bem pontua Ricoeur, "a representância, eu diria hoje, exprime a mistura opaca da lembrança e da ficção na reconstituição do passado" (RICOEUR, 2007: 360). E é por isso que:

\footnotetext{
Uma vez reconhecida essa ruptura epistemológica [entre a narrativa e a história], não seria possível retornarmos á tese demasiado simples, segundo a qual a historiografia seria uma espécie do gênero história narrada (story). (...) E, contudo, a justeza da interpretação narrativista consiste em ter percebido perfeitamente nela que a qualidade propriamente histórica da história só é preservada pelos laços, por mais tênues e dissimulados que sejam, que continuam a vincular a explicação histórica à compreensão narrativa, a despeito da ruptura epistemológica que dissocia a primeira da segunda (RICOEUR, 1994: 324).
}

Este funcionamento relativo à história é análogo a todas as narrativas que possuem uma intencionalidade realista com o mundo, como é o caso do jornalismo. Suas estórias também se estruturam a partir deste pacto implícito da representância com seu público leitor e suas narrativas também se erigem a partir disso que Ricoeur chama de quase-personagens (instituições e processos abstratos) e de quase-intrigas (ou esta afinidade preservada entre a imputação causal singular e a armação da intriga).

Assim, tanto no trabalho jornalístico quanto no historiográfico está-se sempre submetido às limitações do narrar. É por este motivo que Paul Ricoeur (2007: 455) pode afirmar que, antes de tratarmos dos abusos, há que se tratar dos usos da palavra, "a saber, o caráter inelutavelmente seletivo da narrativa. Assim como é impossível lembrar-se de tudo, é impossível narrar tudo. A ideia da narração exaustiva é uma ideia performaticamente impossível". 
A fidelidade com os fatos que estas estórias engendram, portanto, são postas como uma promessa, um voto e, como tal, podem ser traídos ou cumpridos. Mais do que isso: seu cumprimento ou traição está sujeito mesmo a estruturas imaginárias que regem nosso relacionamento com o mundo. Na história e no jornalismo, como aponta Ricoeur (2007: 502), "a originalidade deste voto é que ele consiste não em uma ação, mas em uma representação retomada numa sequência de atos de linguagem" e, nesta condição, esse desejo pode ser entendido como uma reivindicação, como uma pretensão, mesmo que marcada por uma aporia primeira que estaria posta na representação presente de uma coisa ausente.

Estruturadas em torno dessa vontade de encontrar o real nos eventos, existem algumas particularidades e algumas estratégias próprias das narrativas referenciais que buscam assegurar este pacto - ou, ao menos, engendrar uma ilusão referencial de que ele está sendo cumprido. Seguindo o pensamento de Roland Barthes, podemos ver que essas estratégias são, por vezes, comuns à literatura e às narrativas com pretensões realistas (como o jornalismo e a história). Para Barthes (1988), o discurso se reveste de determinadas características que, ao tomar o princípio do "aconteceu" como um princípio suficiente da fala, geram um efeito de realidade que passa a ilusão de encontrar o real que ele representa.

Essas estruturas discursivas - que tentam revestir os acontecimentos dos privilégios do aconteceu - são muito comumente encontradas no jornalismo. Como coloca Sodré (2009: 39), o discurso jornalístico se constrói não a partir de parâmetros meramente informativos, mas sim, autoconfirmativos, de forma que "por mais veraz que seja, a representação do fato põe em jogo crenças ou pressupostos tendentes a validar essa mesma veracidade". São estes aspectos que estudaremos a seguir. Exploraremos autores que mostram como os discursos referenciais tentam camuflar seu caráter essencialmente imaginário.

\section{A vontade de real: a ilusão referencial dos discursos jornalísticos e históricos}

Quando Barthes fala de ilusão referencial, ele está se referindo a este mecanismo presente nos discursos referenciais que, através de uma série de estratégias, criam a ilusão de que o que é representado pode ser misturado ao próprio real, revestindo o discurso, portanto, dos privilégios do aconteceu. Elas podem ser esmiuçadas tanto no plano das enunciações, dos enunciados ou das significações.

No nível da enunciação, uma das características mais manifestas está na ausência dos signos de destinação. Embora toda estrutura do discurso implique um 
sujeito de leitura, o discurso da história parece caracterizado pelo afastamento aparente de um "tu". Os signos relativos ao anunciante (o destinador) são mais frequentes, embora anunciem a existência de um tipo bastante específico de sujeito da fala. Trata-se de um sujeito que anula a sua pessoa passional, substituindo-a por uma existência objetiva, criando uma forma particular de imaginário que Barthes chama de "ilusão referencial". No nível do discurso, a partir desta ausência de signos que remetam a esse anunciante passional, ela se refere à ilusão de que o acontecimento "fala sozinho"11 .

Ou seja, “trata-se do caso em que o enunciador entende 'ausentar-se' do seu discurso e em que há, consequentemente, carência sistemática de qualquer signo que remeta ao emitente da mensagem histórica: a história parece contar-se sozinha". Com isso, "esse acidente tem uma carreira considerável, pois que corresponde de fato ao discurso histórico dito 'objetivo"”, ou seja, aquele no qual o narrador jamais intervém (BARTHES, 1988: 149).

Esses efeitos de sentido não estão presentes apenas no nível da enunciação. Quanto ao enunciado, Barthes coloca que enquanto o estatuto de um processo em geral pode ser assertivo, negativo ou interrogativo, o estatuto do discurso referencial é sempre assertivo (constatativo), se assemelhando ao discurso do esquizofrênico, que não aceita outras possibilidades. E isso porque "o fato histórico está ligado linguisticamente a um privilégio do ser: conta-se o que foi, não o que não foi ou o que foi duvidoso" (BARTHES, 1988: 152). Neste sentido, o discurso histórico não conhece a negação.

No nível da significação, no entanto, é onde Barthes aloca o principal efeito de sentido que o discurso referencial mobiliza. Não obstante $o$ fato de que os acontecimentos não podem ter uma existência dada fora da linguagem, todo o sentido do texto é construído como se essa existência não fosse mais do que a cópia pura e simples de uma outra existência situada em um plano extratextual da realidade.

Este efeito é obtido através de uma aparente desarticulação da tripartidaridade do signo, em que o significado (enquanto estrutura imaginária) é tido como um elemento vergonhoso, passível de ser fundido ao referente. Essa correspondência imediata entre o significante e o referente cria uma ilusão referencial e um efeito de realidade na medida

\footnotetext{
${ }^{11}$ De uma forma geral, Barthes está se confrontando, aqui com historiadores como Leopold Von Ranke ou Augustin Thierry que apresentam o texto histórico como uma síntese de fontes originais e como uma réplica do real. Thierry, por exemplo, costumava sempre apontar que sua meta não era o convencimento através da argumentação, mas sim, a realização de uma narrativa plena: "as pessoas disseram que a meta do historiador era recontar e não provar; eu não sei, mas estou certo de que em história, o melhor tipo de prova, o mais capaz de impressionar e convencer todas as mentes, que permite a menor desconfiança e deixa as menores dúvidas, é a narração completa" (apud BANN, 1994: 58). Através do desnudamento de seus elementos propriamente retóricos e de suas estratégias linguísticas, Barthes procura mostrar a ingenuidade por trás de afirmações historiográficas como estas.
} 
em que o discurso, ao se acreditar revestido pelos privilégios do aconteceu, também se outorga o privilégio de encontrar o real que representa ${ }^{12}$.

Dito de outra forma, essa tentativa de desintegração do signo opera de forma que o significado é expulso da equação e tenta-se uma correspondência imediata entre o significante e o referente. "Suprimido da enunciação realista a título de significado de denotação, o 'real' volta a ela a título de significado de conotação. (...) Noutras palavras, a própria carência do significado em proveito só do referente torna-se o significante mesmo do realismo" (BARTHES, 1988: 164).

Este "efeito de real" é obtido, portanto, porque a realidade se apresenta no discurso histórico como um significado informulado, protegido pela onipresença aparente do referente, segundo as palavras de Barthes. Em resumo, portanto, ele é possível porque o discurso realista é narrado a partir de uma série de elementos que são comuns às narrativas ficcionais, ou seja: (1) o mascaramento do sujeito da fala que cria a impressão de que a história se conta sozinha; (2) o estatuto assertivo do discurso, que toma o ter sido das coisas como princípio suficiente de sua veracidade e (3) a fusão do referente e do significado (enquanto estrutura imaginária) em virtude do referente que, revestido dos privilégios do "aconteceu" acredita encontrar o real que representa.

Trata-se de mecanismos que também estão arraigados na estruturação narrativa da imprensa o tempo todo. O discurso jornalístico epistemologicamente reconhecido ou seja, aquele que está "envolto no real e na verdade como referentes, além de trazer a imparcialidade e a objetividade como operadores" (RESENDE, 2005: 8) - está sempre sujeito a um determinado e padronizado modo de narrar os acontecimentos (expostos nos próprios manuais de redação) que legitimam as regras que produzem estes efeitos de verdade.

O que Resende (2005: 09) chama a atenção, portanto, é para o fato de que ao jornalista “são 'oferecidos' condicionantes que regulam e delimitam o seu campo de atuação - sejam as técnicas que impõem o uso do lead ou, além de outros determinantes, as questões mais subjetivas que o obrigam a narrar os fatos na perspectiva da verdade mais absoluta". Isso significa que os jornalistas "portam-se

\footnotetext{
${ }^{12}$ De uma maneira geral, isto significa que "o discurso histórico supõe, podemos dizer, uma dupla operação, bastante arrevesada. Num primeiro tempo (essa decomposição não é, evidentemente, mais que metafórica), o remetente é destacado do discurso, fica-lhe exterior, fundador, é considerado como seu regulador (...). Mas, num segundo tempo, é o próprio significado que é rechaçado, confundido no referente; o referente entra em relação direta com o significante e o discurso, encarregado apenas de exprimir o real, acredita fazer a economia do termo fundamental das estruturas imaginárias que é significado. (...) Pode-se dizer que o discurso histórico é um discurso performativo com trucagem, em que o constativo (o descritivo) aparente não é de fato mais do que o significante do ato de palavra como ato de autoridade" (BARTHES, 1988: 155-156).
} 
como senhores-sabe-tudo - não necessariamente porque assim se sintam ou porque assim o queiram - mas por terem suas falas legitimadas (diante das perspectivas históricas que aqui estão sendo traçadas) por estratégias textuais que regem o enunciado que eles construirão".

Os chamados rituais de objetividade - que visam garantir que esta vontade imaginária de real se cumpra - transbordam mesmo para a narrativa de forma que o texto jornalístico é, normalmente, um texto sem um autor demarcado. "Não há, na perspectiva da narrativa jornalística tradicional, alguém que conta a história" (RESENDE, 2005: 4). O narrador jornalístico, como coloca Motta (2008), narra sempre como se a real estivesse lá fora apenas esperando para ser contado, independentemente da posição de um observador ou de alguém para contar, operando a partir de uma desubjetivação do relato. Assim, o jornalista é um narrador discreto uma vez que "utiliza recursos de linguagem que procuram camuflar seu papel como narrador, apagar a sua mediação. É um narrador que nega até o limite a narração. Finge que não narra, apaga a sua presença. Faz os fatos surgirem no horizonte como se estivessem falando por si próprios" (MOTTA: 2008). Como tentaremos mostrar posteriormente, o uso da História é também uma estratégia para o apagamento deste sujeito que fala.

O sujeito do enunciado se confunde com o sujeito da enunciação, de forma que a enunciação é subordinada ao enunciado. Trata-se, o tempo todo, de construir uma ideia de que a enunciação se resumiria a uma mera técnica (RESENDE, 2005). Da mesma forma, os enunciados possuem sempre um estatuto assertivo e, a partir dessa ilusão de conjunção entre o referente e o significante, todo o discurso jornalístico também tenta se revestir o tempo todo dos privilégios do aconteceu.

Uma vez que a própria noção de objetividade se estrutura enquanto estratégia argumentativa, o estatuto assertivo do jornalismo é trabalhado a partir de expressões que criam a impressão de atualidade, de referenciais geográficos e de expressões de autoridade que dissimulam a mediação e acabam se configurando como uma forma de legitimar a própria prática. Estatísticas, mapas, infográficos, ilustrações são outros mecanismos que criam a ideia de um calçamento no real e de uma empiricidade na fala.

Como coloca Motta (2008), mecanismos simples como a utilização de dêiticos são responsáveis por construir grandes campos de referencialidade, uma vez que demarcam o tempo e o lugar da enunciação criando, assim, as condições de unicidade do ato de fala. Mais do que isso, criando também os lugares e o estatuto dos interlocutores na relação. 
O que gostaríamos de nos perguntar, postas essas condições que constituem o texto jornalístico como uma construção imaginária do mundo calcada em um discurso referencial, é o seguinte: seria a remissão histórica também uma estratégia utilizada para criar um efeito de realidade nas narrativas da imprensa?

A partir de um cruzamento de características que aproximam e que diferenciam o discurso histórico e o discurso jornalístico, partiremos da noção que sim. É sobre isso que iremos discorrer no próximo tópico. Procuraremos investigar como, ao evocar a história, o jornalismo tenta invocar uma estratégia referencial.

\section{A História como fala do Outro: o reforço da ilusão referencial jornalística a partir da evocação histórica}

Dentre as várias estratégias que evidenciam essa busca pela referencialidade dentro do texto jornalístico, podemos colocar que a recorrência a terceiros tem um estatuto privilegiado. O discurso do outro sempre teve uma importante função legitimadora na imprensa e ajuda a criar a impressão de que há uma polifonia de vozes no texto, de forma que o jornalista possa se apresentar como um mero coletor de evidências. "Em princípio, a função do discurso citado no texto jornalístico concerne à garantia dos efeitos de realidade e, sobretudo, de objetividade e de imparcialidade" (MOURA, 2006: 72).

Este discurso de um outro introduzido por meio de uma citação - que atua ao "retirar um material já significante de dentro de um discurso para fazê-lo funcionar dentro de um novo sistema significante" (MAINGUENEAU, 2002: 125) -, como coloca Maingueneau, é uma maneira hábil, porque indireta, de se introduzir uma opinião com uma aparência objetiva, uma vez que é um terceiro que assume o dito - terceiro esse muitas vezes ligado a uma posição de autoridade. O narrador aparece como um não-eu remetendo ao entendimento de que uma determinada asserção é verdadeira porque não é o próprio narrador quem a diz.

Se o recurso à fala de um terceiro é um importante procedimento de engendramento da ilusão referencial dentro dos textos jornalísticos, a remissão à História funciona mesmo como um outro possível a quem se pode fazer referência. Para entendermos isso, é necessário explorar algumas características do discurso histórico e a relação que ele próprio também estabelece com um outro - relação esta bastante diferente daquela que é posta pelo jornalismo.

A construção do discurso histórico, para Michel de Certeau, não pode ser separada de uma estrutura mais ampla que marca toda a inteligibilidade da cultura 
ocidental moderna: o fato de que os saberes se instauram em uma relação com o outro. Isso significa dizer que ela "desdobra uma problemática articulando um saber dizer a respeito daquilo que o outro cala" (CERTEAU, 2008: 15).

Assim, da mesma forma que um médico transforma o corpo do paciente em um quadro legível (e, portanto, traduzível em linguagem), tal qual um código que pode ser decifrado, tal como um cadáver mudo exposto ao olhar que exige uma leitura especializada, a história opera o mesmo mecanismo com a memória ${ }^{13}$. "Uma mutação análoga se produz quando a tradição, corpo vivido, se desdobra diante da curiosidade erudita em um corpo de textos". Assim, "estas duas heterologias (discursos sobre o outro) se constituíram em função da separação entre o saber que contém o discurso e o corpo mudo que o sustenta" (CERTEAU, 2008: 15).

E é por este motivo que o autor enfatiza a noção de que a historiografia nada mais faz do que fornecer túmulos escriturários para os mortos do passado, sendo que "a única pesquisa histórica do 'sentido' permanece, com efeito, a do Outro". O tratamento que ela dá a estes mortos, no entanto, é também bastante específico, na medida em que ela pretende, ao mesmo tempo, "compreender e esconder com o 'sentido' a alteridade deste estranho ou, o que vem a ser a mesma coisa, acalmar os mortos que ainda frequentam o presente" (CERTEAU, 2008: 14).

A própria divisão da história em períodos - como Idade Média, Idade Moderna, etc. - já marca a diferença e efetiva a decisão de ser um outro ou de, no mínimo, não ser mais o que havia sido até o momento. Este novo que emerge acaba por atestar aquilo que o precedeu como morto e receber um passado já marcado por rupturas anteriores. "Logo, o corte é o postulado da interpretação (que se constrói a partir de um presente) e seu objeto (as divisões organizam as representações a serem reinterpretadas)" (CERTEAU, 2008: 15).

Este outro, enquanto um objeto de saber mudo, não nos diz a respeito das origens ou do começo das coisas como forma de explicação do presente. Seu ponto de partida é sempre inverso: ele parte de determinações presentes e a atualidade é sempre o seu começo real. A historiografia, ao representar esse passado do qual se distingue,

\footnotetext{
${ }^{13}$ Embasado pelas ideias de Michel Foucault, Certeau (2008: 15) afirma que "do século XVII ao XVIII, o que torna possível a convertibilidade do corpo visto em corpo sabido, ou da organização espacial do corpo em organização semântica de um vocabulário - e inversamente - é a transformação do corpo em extensão, em interioridade aberta como um livro". Isso nos leva à problemática de que tanto uma medicina quanto uma historiografia modernas "nascem quase simultaneamente da clivagem entre um sujeito supostamente letrado, e um objeto supostamente escrito numa linguagem que não se conhece, mas que deve ser decodificada" (CERTEAU, 2008: 15).
} 
portanto, acaba por fazer uma triagem dos fatos de forma que devem ou não ser lembrados como forma de obter uma inteligibilidade para o presente.

É por isso que o ato de escrever sobre o passado é "encontrar a morte que habita este lugar, manifestá-la por uma representação das relações do presente com o seu outro e combatê-la através do trabalho de dominar intelectualmente a articulação de um querer particular com forças atuais" (CERTEAU, 2008: 22).

Mais do que isso, no entanto, estão postas em sua operação, "as permanências ocultas" e "as rupturas instauradoras" que formam um amálgama, marcando uma relação ambígua com o passado que representa. Isso porque, se por um lado, a noção de um passado que já está acabado marca uma relação de identidade por diferenciação - a partir da suposição de uma ruptura que transforma uma tradição em um objeto do passado, em um outro - o corte se dá apenas por separação, de forma que não há uma eliminação efetiva.

Assim, "se, por um lado, a história tem como função exprimir a posição de uma geração com respeito às precedentes, dizendo: 'eu não sou isto', acrescenta sempre, a esta afirmativa, um complemento não menos perigoso, que faz uma sociedade confessar: 'eu sou outra coisa além daquilo que quero e sou determinada por aquilo que denego" (CERTEAU, 2008: 56). É por isso que, a partir deste jogo entre dependência e autonomia, que o discurso histórico é ao mesmo tempo sua representação e seu reverso $^{14}$. Pensada desta forma, Certeau pode se apropriar da frase de Michelet, para quem, a História se comporta como a autobiografia de um povo ou de uma nação.

Essa questão é retomada por Paul Veyne quando ele afirma que o interesse social pela história está calcado no fato de que ela trata de civilizações exóticas e de objetos trazidos pelas escavações que são tão curiosos e surpreendentes quanto os aerólitos. O interesse por uma civilização como a romana, por exemplo, está posta porque "entre os romanos e nós um abismo foi cavado pelo cristianismo, pela filosofia alemã, pela revolução tecnológica, científica e econômica, por tudo o que compõe nossa

\footnotetext{
14 “A história está, pois, em jogo nessas fronteiras que articulam uma sociedade com o seu passado e o ato de distinguir-se dele; nessas linhas que traçam a imagem de uma atualidade, demarcando-a de seu outro, mas que atenua ou modifica, continuamente, o retorno do 'passado'. Como na pintura de Miró, o traço que desenha diferenças através de contornos e que torna possível uma escrita (um discurso e uma 'historicização') é atravessado por um movimento que lhe é contrário. Ele é vibração de limites. A relação que organiza a história é uma relação mutável, na qual nenhum dos (dois) termos é o referente estável" (CERTEAU, 2008: 48). Certeau também aproxima o entendimento histórico com a relação que os povos antigos mantinham com os mitos. E isso porque, "o relato dessa relação de exclusão e de atração, de dominação ou de comunicação com o outro (posto preenchido alternadamente por uma vizinhança ou por um futuro) permite à nossa sociedade contar-se, ela própria, graças à história. Ela funciona como o faziam ou fazem ainda, em civilizações estrangeiras, os relatos de lutas cosmogônicas, confrontando um presente a uma origem" (CERTEAU, 2008: 55).
} 
civilização. E é por isso que a história romana é interessante: faz-nos sair de nós mesmos e obriga-nos a explicitar as diferenças que nos separam dela" (VEYNE: 1983b, $11)$.

Ao contrário do jornalismo, portanto, que remete a um outro como forma de legitimar o seu texto, a História já é a representação de um outro (um outro que não o presente), de forma que este outro alude, ao mesmo tempo, a um corte e a uma dívida. $\mathrm{O}$ jornalismo usa a história, portanto, porque ela se configura como um destes outros a quem se pode fazer referência para afirmar seu estatuto referencial.

Obviamente que se trata de um efeito ilusório, pois, como já havíamos posto, a história também está sujeita às estruturações do discurso e da narrativa. Trata-se, no entanto, como já aludimos a partir de Barthes, de um estatuto camuflável, uma vez que o próprio discurso histórico remete às suas próprias ilusões referenciais. A forma como o jornalismo a olha, no entanto, é distinta e a História assume mesmo um lugar de autoridade, ligado a um outro que legitima uma posição.

Além de engendrar a própria fala como a fala de um outro, a citação de fatos da história nas narrativas jornalísticas também diz respeito a uma estratégia referencial na medida em que efetiva o apagamento do autor dentro da narrativa - que, conforme já dissemos funciona como uma estratégia para que se crie a impressão de que o acontecimento se conta sozinho. Ao se configurar como o discurso de um outro, a história funciona mesmo como uma citação que está mesmo nesta esfera do não-eu, de forma que é algo externo ao jornalista que se apresenta como o produtor da fala, operando, neste ato mesmo, o apagamento da pessoa passional do jornalista e a sua substituição por uma entidade objetiva.

Existem outros elementos que também precisam ser levados em consideração. $\mathrm{O}$ recurso à fala de um terceiro nas narrativas jornalísticas, de uma maneira geral, pode funcionar tanto como forma de respaldar um determinado posicionamento, como também para rejeitá-lo. No caso das narrativas citadas provenientes da história, no entanto, essa relação não está posta e o dito assume mesmo uma posição de veracidade. Vejamos como.

O julgamento epistêmico, como coloca Charaudeau (2006: 49), pode se estruturar a partir de duas noções diferentes que são os valores de verdade e os efeitos de verdade. O primeiro, embora não seja necessariamente de ordem empírica, "se realiza através de uma construção explicativa elaborada com a ajuda de uma instrumentação científica que se quer exterior ao homem (mesmo que seja ele quem a 
tenha construído), objetivante e objetivada, que pode definir-se como um conjunto de técnicas de saber dizer, de saber comentar o mundo".

Os efeitos de verdade, por sua vez, são diferentes na medida em que estão mais ligados aos valores da crença do que da experimentação. Relacionada à subjetividade do indivíduo em sua forma de compartilhamento social, esta noção se inscreve nas normas de reconhecimento do mundo, na medida em que "diferentemente do valor de verdade, que se baseia na evidência, o efeito de verdade se baseia na convicção e participa de um movimento que se prende a um saber de opinião". E é por isso que "o que está em causa aqui não é tanto a busca por uma verdade em si, mas a busca por 'credibilidade', isto é, aquilo que determina o 'direito à palavra' dos seres que comunicam e as condições de validade da palavra emitida" (CHARAUDEAU, 2006: 49).

Tanto o discurso da história quanto o discurso do jornalismo são construídos a partir de valores e de efeitos de verdade, em diferentes níveis. Devemos considerar, no entanto, que se a História - entendida como uma prática científica - tende mais para a construção de suas matrizes de verdade presumida a partir dos valores de verdade; o jornalismo tende a calcar seus textos em efeitos de verdade.

Nesta linha de argumentação, autores como Eduardo Meditsch (1997) defendem que a imprensa estrutura o seu verdadeiro a partir da mediação e da elaboração de um conhecimento do senso comum. E isso significa que o conhecimento jornalístico "é frágil, enquanto método analítico e demonstrativo, uma vez que não pode se descolar de noções pré-teóricas para representar a realidade". Seu ancoramento está, portanto, em outras bases, sendo menos rigoroso e formal do que as práticas das ciências humanas em geral. Este ancoramento está justamente ligado ao estabelecimento de um campo (mesmo que limitado) de embate de ideias. Diz respeito, portanto, fundamentalmente a este saber de opiniões, embora recorra constantemente aos valores de verdade como forma de representar o mundo.

Ao fazer remissão a discursos científicos como a História, é como se o jornalismo pudesse também tomar para si um pouco mais deste estatuto ligado ao valor de verdade. É como se a História - assentada como prática do saber - pudesse emprestar ao jornalismo um efeito de referencialidade maior, uma vez que ela está mais ligada a esta autoridade de comentar o mundo a partir de técnicas empíricas. Neste sentido, a remissão a fatos do passado funciona não apenas como a fala de um outro, mas, mais do que isso, como a fala de outro que é acreditado em uma esfera científica, como um campo de saber legitimado, ligado a uma posição de autoridade. 
Esta posição de autoridade ocupada pela história enquanto campo de saber não é nada banal e não é de se admirar que ainda na França do século XV os historiadores recebessem uma pensão do rei e que o seu ingresso na Academia Real das Inscrições e Belas Letras estivesse submetido a uma permissão real que deveria atestar seus "bons costumes e probidade reconhecida" 15 .

Como bem aponta Certeau (2008: 76), "antes de dizer o que a história diz de uma sociedade, é necessário saber como funciona dentro dela”. É este lugar ocupado o que permite e o que proíbe, de forma que a sua credibilidade está sujeita mesmo a este jogo de possibilidades. E assim, "a história se define inteira por uma relação da linguagem com o corpo (social) e, portanto, também pela sua relação com os limites que o corpo impõe, seja à maneira do lugar particular de onde se fala, seja à maneira do objeto outro (passado, morto) do qual se fala".

E, dentro deste espectro social mais amplo - apesar das discussões dos historiadores em torno do estatuto essencialmente imaginário da narrativa -, o lugar particular de onde a história fala está mesmo revestido dos privilégios do aconteceu, de forma que suas postulações se estruturam sob um valor de verdade - valor este que é constantemente aproveitado pelo jornalismo como um dado.

Em outros termos, podemos dizer que o lugar ocupado pela História dentro de um universo de discursos é aquele Maingueneau (2008: 37-38) chama de discursos constituintes, ou seja, aqueles que têm como característica a de "não reconhecer outra autoridade além de sua própria, de não admitir quaisquer outros discursos acima deles". Trata-se de discursos que dão sentido aos atos da coletividade na medida em que, como exemplifica o autor, um jornalista ocupado de uma determinada temática irá recorrer à autoridade do historiador ou do cientista, mas o inverso dificilmente ocorre. É neste sentido que os discursos constituintes preponderam sobre as outras falas e "não reconhecem discursividade para além da sua e não podem se autorizar senão por sua própria autoridade".

Ele assume, portanto, um papel de autoridade em relação a outros corpos de textos e acaba por forma-lhes o conteúdo e o direcionamento de sentidos. Essa noção está relacionada mesmo com o ethos que determinada prática discursiva assume em uma sociedade, de forma que há um investimento imaginário do papel ocupado por ela e "o enunciador é percebido através de um 'tom' que implica certa determinação de seu

\footnotetext{
${ }^{15}$ Esse mecanismo permanece até o século XVIII, quando "a perenidade da função real sendo assim reafirmada, as histórias da França deviam fazer passar os reis sob o olhar do tribunal da história, exaltando os bons soberanos para edificar as gerações futuras e destinando aos infernos os maus príncipes. Certo número de virtudes servem para praticar discriminações necessárias: a justiça, a coragem, a bondade, a sabedoria, ou ainda, o amor pelo povo" (DOSSE, 2003: 271).
} 
próprio corpo, á medida do mundo que ele instaura em seu discurso" (MAINGUENEAU, 2008: 53).

Tomando como pressuposto o fato de que nos discursos constituintes há constituição "precisamente na medida em que um dispositivo enunciativo funda, de uma forma que é de certa maneira performativa, sua própria existência, fazendo como se extraísse essa legitimidade de uma Fonte da qual ele seria apenas a encarnação (o Verbo revelado, a Razão, a Lei, etc.)" (MAINGUENEAU, 2008: 54), a História pode ser alocada neste lugar na medida em que ela parece fundar o Passado.

Dentro das narrativas jornalísticas, portanto, ela já está assegurada dentro deste papel da verdade, como um discurso que fornece conteúdo e molda os entendimentos da estória contada. É como se houvesse, a partir de menções e citações, uma repartição de sua autoridade. É como se ela funcionasse como uma prova de verdade.

É necessário considerar dentro desse quadro, obviamente, a questão de que, assim como a montagem narrativa, também as provas de verdade no discurso jornalístico são de ordem imaginária e estão relacionadas mesmo aos valores dessa comunidade interpretativa. Charaudeau (2006: 55-56) aponta para três modos em que ela se processa, a saber, a autenticidade (ou os mecanismos discursivos que buscam assegurar a própria existência dos seres no mundo, ligados a um movimento de designação relacionado a uma prova concreta), a verossimilhança (que busca reconstituir analogicamente a existência de uma situação similar no passado ou no futuro a partir de uma suposição de ordem reconstitutiva) e a explicação (relacionada à possibilidade de determinar o porquê dos fatos a partir de um processo de elucidação a partir de diversas fontes de pesquisa). Como tentaremos mostrar mais detidamente durante as análises do corpus coletado, a História atua em um reforço da veracidade jornalística nestes três pólos.

Em suma, as representações dos fatos do passado engendradas pelas narrativas históricas operam a passagem, de acordo com Paul Ricoeur (2007), de uma cena traumática para uma cena simbólica. As expectativas sociais coordenadas em torno desta narrativa, no entanto, muitas vezes ignoram seu caráter essencialmente imaginário e colocam o discurso da História como um outro capaz de realizar o desejo de imparcialidade, tal como um juiz. "A razão é que os papéis respectivos do historiador e do juiz, designados por sua intenção de verdade e de justiça, os convidam a ocupar a posição do terceiro em relação aos lugares ocupados no espaço público pelos protagonistas da ação social". Este papel é importante na medida em que "um desejo de 
imparcialidade está ligado a essa posição de terceiro", mesmo que esta se apresente "sob o signo da impossibilidade de um terceiro absoluto" (RICOEUR, 2007: 330).

A dupla ausência dos discursos históricos (uma delas que é posta pela sua dependência com a linguagem e a outra alocada na condição de decorrido do referente), portanto, muitas vezes é relegada em proveito de um efeito de real e de uma ilusão referencial. Quando inseridas nas narrativas jornalísticas, essas remissões à história funcionam mesmo como um lugar de verdade, sendo que, nas narrativas das revistas semanais, essa verdade adquire alguns contornos ainda mais específicos.

Para entendermos isso é necessário deixar claro com qual tipo de jornalismo estamos lidando, ou seja, com o jornalismo das revistas interpretativas, que contém algumas características bastante particulares em suas construções. Elas dizem respeito a algumas questões aludidas nas falas seguintes.

Na comemoração de aniversário dos 40 anos da revista Veja, no dia 02 de Setembro de 2008, Roberto Civita afirmou categoricamente que a função da revista, desde seu início, era honrar o compromisso com seu público e que isso significava basicamente "informá-los corretamente, contar-lhes a verdade e opinar" (CIVITA, 02/09/2008 - grifo nosso). Da mesma forma, Mino Carta escreveu, no editorial da edição comemorativa de 15 anos de Carta Capital, que a ética da publicação estava alicerçada na máxima “opinião exposta sem meios-termos” (CARTA, 27/05/2009: 13).

Estamos lidando, portanto, com um jornalismo essencialmente opinativo.

A partir do que colocamos até o momento, podemos pensar que, como o discurso histórico é construído a partir de uma ilusão referencial - que acredita encontrar o real que representa a partir dos privilégios do "aconteceu" - sua inserção nas narrativas jornalísticas criam um efeito de sentido tal como se ele se constituísse como este terceiro imparcial de que nos fala Ricoeur. É como se o discurso histórico, a partir de todas as suas características que foram descritas anteriormente, se posicionasse como uma testemunha insuspeita em meio a dois fenômenos suspeitos: o próprio acontecimento do presente noticiado de um lado (enquanto não transparente) e o jornalista (que está inserido em um tipo de jornalismo explicitamente opinativo).

Este efeito de sentido, obviamente, pode ser desmobilizado a partir da noção de que, assim como as narrativas jornalísticas, o discurso histórico não passa de uma construção. Isso explica, no entanto, o fato de que, apesar de os dados históricos inseridos apresentarem, em algumas ocasiões, informações redundantes em relação à narrativa mais ampla da reportagem, eles são utilizados, não obstante isso, em um número bastante grande de textos. 
Ao ocupar a posição deste terceiro, o discurso da história inserido nas narrativas jornalísticas colabora, portanto, com esta construção de efeito de sentido de imparcialidade.

Esta não é, no entanto, a única coisa evocada nesta equação. Assumindo um papel formador para outros discursos, uma outra característica dos discursos constituintes está relacionado ao fato de que eles "pretendem delimitar, com efeito, o lugar-comum da coletividade, o espaço que engloba a infinidade de 'lugares-comuns' que aí circulam” (MAINGUENEAU, 2008: 39). E assim, eles se colocam em um papel de permanente reatualização através de sua reinscrição repetitiva em outros enunciados escritos em contextos diferentes.

Se estamos lidando com o lugar ocupado pela História que, por conseguinte, permite ou proíbe determinados usos em torno do seu estatuto, precisamos levar em consideração que, mais do que uma ciência, a História representa também uma forma de o homem dotar o tempo de sentido e de fazer referência a um mundo comum.

Mais do que uma estratégia textual que dota o discurso jornalístico de referencialidade, a História também está ligada a estruturas do imaginário que dizem respeito a uma busca - que também é a do jornalismo - de configurar e mediar a temporalidade e o vínculo societário. É sobre este aspecto que iremos nos deter no próximo capítulo: mais do que uma mera estratégia referencial, ao evocar a História, o jornalismo também invoca uma determinada ideia de tempo e de comum. 


\section{CAPÍTULO II}

\section{O JORNALISMO E A HISTÓRIA \\ DUAS CONSTRUÇÕES DO TEMPO, DUAS CONSTRUÇÕES DO COMUM}

A partir dos subsídios teóricos do capítulo anterior, podemos entender porque "não há nenhum sentido em falar de acontecimentos em si; só se pode falar de acontecimentos sob descrição" (QUÉRÈ apud CHARAUDEAU, 2006: 103). E isso evoca o fato de que o acontecimento jornalístico - essencialmente imaginário e inconcebível fora da perspectiva do discurso e da narrativa - se configura apenas após a passagem por um processo evenemencial, ou seja, por um por um mecanismo que, nas palavras de Charaudeau, transforma os acontecimentos que podem ter alguma ancoragem no mundo físico em outra coisa que não uma mera adequação imagética ao referente, na medida em que sua percepção e significância dependem de um sujeito que interpreta o mundo.

O acontecimento percebido que irrompe do continuum dos eventos em sucessão, desta forma, se inscreve sempre dentro de uma rede de significações sociais, de modo que ele seja reintegrado em um conjunto de significados já estabelecidos. Existem diversas formas a partir das quais o jornalismo se insere dentro desse jogo das significações sociais. Neste capítulo, procuraremos explorar uma delas: o vínculo societário estabelecido pelo o que é comum a partir do modo com que o jornalismo se relaciona com a temporalidade.

E isso porque, se essa rede de significações sociais pode ser mobilizada e dizer respeito a todos os processos de significação, as mídias recobrem algumas características específicas dentro deste processo mais geral. Entre eles, podemos destacar o fato de que a imprensa se estrutura a partir de um relacionamento bastante específico com a construção de um tempo imaginário e de um comum imaginário que possuem alguns contornos próprios.

O próprio Charaudeau (2006: 101) coloca que "sendo a finalidade da informação midiática a de relatar o que acontece no espaço público, o acontecimento será selecionado e construído em função de seu potencial de 'atualidade', de 'socialidade' e de 'imprevisibilidade"”.

É em torno destes elementos que iremos discorrer agora. E, a partir do modo como eles se configuram no jornalismo - e, mais especificamente no jornalismo do tipo interpretativo, exercido pelas revistas informativas semanais estudadas - iremos investigar como a evocação da História e do passado contribuem para uma afirmação 
destas características. Em suma, iremos investigar como o jornalismo, ao evocar a história (e a partir da maneira específica a partir da qual ele lida com a temporalidade) invoca uma construção do comum, de forma que o passado funciona como um modo de inscrever o fato jornalístico em uma rede de significações sociais, reintegrando-o em um conjunto de significados já estabelecidos.

\section{A Construção Imaginária do Tempo no Jornalismo}

Giacomo Marramao (1995: 23) chama a atenção para o fato de que a forma como o homem entende o poder está em íntima relação com a sua concepção e vivência da temporalidade. Assim, "cada civilização - cada Kultur - se dá sempre associada a certa experiência do tempo, e, portanto, toda passagem de civilização implica necessariamente uma mudança fundamental na intuição do tempo, mudança que condiciona de modo determinante o quadro dos valores e - consequentemente - da política"16.

Essa construção imaginária do tempo que funda uma determinada legitimidade é também trabalhada por Le Goff (2003) quando ele coloca que sempre existiram "os senhores do calendário", na medida em que quem controla o tempo, controla também os ritmos sociais como o trabalho, o tempo livre e as festas. A construção imaginária do tempo é, neste sentido, um instrumento de poder.

Desde as sociedades que se apoiavam em uma concepção cíclica, passando pela escatologia cristã até os tempos atuais - que, segundo Giner (1995: 20) se caracteriza pelo fato de que "o poder se legitima com os resultados mundanos que sua gestão produzirá amanhã", sendo que a nova relação tempo-poder se ancora em "um presente que é função de um futuro decretado por vontade política" - as diversas práticas sociais sempre se fundaram em uma relação imaginária com o tempo que serve como justificação de sua autoridade.

Essa correspondência não é diferente no que concerne às práticas midiáticas. Sua autoridade e legitimidade também estão calcadas em um determinado relacionamento imaginário com o tempo, de forma que a "atualidade" e a "imprevisibilidade" são pilares que sustentam essa prática social dentro de um quadro específico de saberes. É neste sentido que podemos assumir que "o jornalismo não cria o tempo presente, mas atua de forma privilegiada como reforço de uma temporalidade social" de forma que "os eventos jornalísticos não são apenas marcadores simbólicos sobre o tempo presente,

16 "Portanto, a semântica do tempo, como toda semântica, remete a uma pragmática e a uma sociopragmática, ou seja, àquela rede de possibilidades e de inter-relações que fornecem o horizonte formalmente determinado - de sentido do agir" (MARRAMAO, 1995: 23-24). 
mas são definições temporais sobre modos de viver o presente" (FRANCISCATO, 2005: 21).

Franciscato (2005: 64) coloca mesmo o advento histórico do jornalismo como um subproduto de uma época em que a "vivência do tempo presente ganhou predominância e serviu como modo de orientação e organização temporal para as relações sociais". O jornalismo teria surgido, assim, como fruto de uma organização social que começava a experimentar uma vivência forte de uma "cultura do tempo presente", ou seja, de uma sociedade em que "viver o presente se torna como que uma obsessão social, tanto pelos fatores culturais quanto pela organização de sociedades urbanizadas que dependiam da regulagem do tempo para obter um sincronismo de ações" (FRANCISCATO, 2005: 63).

Entre os séculos XVIII e XIX, no berço da imprensa, uma série de produtos culturais passaram a expressar uma fascinação pela contemporaneidade e há uma verdadeira proliferação de relatos e de histórias da vida cotidiana (ficcionais ou não), de maneira que o jornalismo - com suas "narrativas curtas e efêmeras de ocorrências estranhas, mas verdadeiras" - passou a ocupar um papel central na criação e ampliação de uma "cultura do agora" que colocava uma "peculiar combinação de news and new things que se tornou uma obsessão" (FRANCISCATO, 2005: 65-66).

Dentro deste quadro, um dos pilares da autoridade jornalística se firmou, justamente, dentro deste quadro de saberes sobre o tempo presente, de forma que o tempo da estória (ou o tempo da narrativa) contada nos jornais é construído através de uma projeção do tempo da história (ou o tempo do evento), de forma que se construa uma ilusão de indissociabilidade entre ambos. A atribuição de valor ao conteúdo jornalístico se afirma justamente a partir da noção de que ele está conectado temporalmente ao evento relatado, o que pode ser chamado de "atualidade" jornalística.

Trata-se de um aspecto que, no entanto, deve ser visto com algum cuidado. E isso porque embora o tempo presente sempre tenha tido uma grande ênfase nas Teorias do Jornalismo - e é nesse sentido que Isabel Travancas (1993: 34) pode afirmar que "a notícia se define pela novidade, pelo que é novo, sendo, portanto, o tempo que transforma o novo em velho, a novidade em conhecimento" - podemos afirmar, como bem coloca Felipe Pena (2005: 39), que no jornalismo "a novidade nem sempre é atual e a atualidade nem sempre é nova".

Isso significa que, embora a ênfase no estudo do tempo presente seja bastante justificada, é necessário sublinhar, contudo, que esta temporalidade não é marcada tal como um presente plano. Franciscato (2001) coloca mesmo que a noção de "atualidade 
jornalística", só pode ser entendida se ampliarmos o seu significado e não nos restringirmos a uma mera conceitualização do novo. E isso porque a "atualidade jornalística" não se constitui somente como a qualidade temporal de um fenômeno, mas sim, como forma de dotar um conteúdo de determinados atributos que o colocam como um elemento importante na constituição da sociabilidade contemporânea.

O processo de semantização de um acontecimento jornalístico, visto sob esta perspectiva, não abarca somente o tempo presente, mas está diretamente conectado com outros tempos narrativos que acabam por sugerir direcionamentos e atribuir sentidos para o que é relatado. Podemos entrever, por exemplo, uma outra construção temporal bastante comum no jornalismo que, embora seja um pouco menos óbvia, diz respeito a uma certa orientação para o futuro a partir da formação de prognósticos.

Desde o início do jornalismo, seu conteúdo foi construído não somente como uma orientação para o imediato, como também a partir da busca de pistas no desenrolar dos eventos do presente, algumas pistas para o porvir. Para Franciscato (2005: 108109), o surgimento da imprensa periódica constrói novos sentidos para a marcação da temporalidade do presente, na medida em que cria um elo entre o início de cada novo dia e os eventos que aconteceram no dia anterior. Assim, "essa característica do jornalismo cria no leitor a sensação de possuir em suas mãos, em cada manhã, o jornal trazendo um quadro satisfatório de relatos sobre como os eventos se encerraram no dia anterior, o que lhe possibilitaria projetar um cenário das coisas que irão ocorrer no novo dia”. Esse jogo de projeções acompanha toda a produção noticiosa, de forma que, como coloca Noblat (2004: 114), "o sonho de todo mundo é ler hoje o jornal de amanhã".

Partindo da noção de que as notícias participam de um processo de aceleração do tempo, também Virilio (1996: 46) contesta a afirmação aparentemente banal de que "a informação é praticamente a única mercadoria que não vale mais nada depois de 24 horas". Isso porque, para o autor, durante quase todo o século XIX e XX os jornais se preocuparam menos em produzir informações do que em antecipá-las, como se os fatos pudessem ser capturados "em movimento". E, neste processo, "os jornalistas e publicitários se entregaram ao perigoso jogo dos prognósticos". O autor chama a atenção para o fato de que a precipitação e a aposta em prognósticos são mesmo valores enredados nas estruturas da produção noticiosa.

John Huxford (2004: 31) chega a afirmar que "a popular visão das notícias como crônicas de eventos que aconteceram nas últimas 24 horas talvez ignorem o aspecto mais significativo do processamento de notícias. Em grande parte, a importância das notícias está na maneira como o jornalismo se posiciona na interface entre o passado e o 
futuro, de onde ele traça as implicações das ocorrências", preenchendo, desta forma, o que acontecerá depois no evento noticiado.

Neste sentido, o autor pontua que a notícia de um derramamento de resíduos tóxicos em um lago, por exemplo, não teria qualquer significado sem a descrição dos cenários futuros que podem acompanhar este acontecimento a partir do levantamento das possíveis consequências do ato (como a contaminação dos humanos que beberem aquela água ou a possível destruição da fauna e da flora daquele lugar). Mais do que a mera descrição dos fatos, portanto, o jornalismo guardaria uma dimensão a partir da qual ele se entrega a fórmulas de especulação sobre o futuro, uma vez que esta projeção é um componente não desprezível do sentido que será dado a um acontecimento relatado.

É nesta dimensão que toma a temporalidade da imprensa como a construção de uma série de tempos sociais que se interpõem, que Marcondes Filho afirma que (2000: 67) “o jornalismo não age só no plano imediato. A soma de todos os imediatos diários constrói um contínuo sedimentado na extensão do tempo. Se a essência da técnica é algo de natureza não técnica, a essência do instantâneo é algo, necessariamente, de natureza não-passageira".

A construção social de sentidos envolta no jornalismo, portanto, está além de uma mera descrição do tempo presente, mas diz respeito mesmo, a uma expansão em direção ao passado e ao futuro, de forma que os prognósticos dizem respeito mesmo a uma ampliação das funções da imprensa noticiosa e a uma forma de imprimir determinados direcionamentos de sentido para um evento.

Se estas questões podem ser ditas a respeito do jornalismo como um todo, a noção da atualidade e do prognóstico como elementos formativos e de legitimidade da produção noticiosa ganha algumas tonalidades específicas quando lidamos com o jornalismo de revista. E isso porque estamos diante de uma prática midiática que se define, justamente, por seu caráter interpretativo. Desde a sua formação, a produção noticiosa em revista estava comprometida com um tipo de jornalismo que se relaciona de uma maneira um pouco mais aprofundada com as múltiplas temporalidades envolvidas na produção noticiosa.

Apesar de o termo "revista" ter sido utilizado pela primeira vez em um título de um periódico em 1704, o primeiro registro de uma publicação que se assemelhava a ela data do ano de 1663 com as Erbauliche Monatsunterredungen (Edificantes Discussões Mensais). Ao apresentar questões não tão aprofundadas quanto os livros, mas mais pormenorizados do que nos noticiários ligeiros, as revistas nascem com a característica 
de serem destinadas a um público específico que se reúne em torno de uma temática. É por este motivo que Scalzo (2003: 21) comenta que "enquanto os jornais, tanto diários quanto semanais, nascem e crescem engajados, ligados a tendências ideológicas, a partidos políticos e à defesa de causas públicas, as revistas acabam tomando para si um papel importante na complementação da educação, relacionando-se intimamente com a ciência e a cultura".

Com o tempo, começam a surgir revistas com temáticas variadas ${ }^{17}$, mas embora já existissem algumas publicações esparsas com caráter similar, é o lançamento da revista Time que fixa de uma vez por todas o modelo de revista semanal informativa e interpretativa $^{18}$. O projeto da Time estava todo estruturado em torno de um "abandono da linguagem tradicional e imparcial do jornalismo diário a favor de uma voz que pretende estabelecer sua autoridade como um líder nacional e forjar uma ligação pessoal com seus leitores, e interpretar bem como informar" (KITCH, 2005: 17). O elemento interpretativo dentro deste modelo de revista informativa, portanto, não é só uma característica de seu conteúdo, como também o elemento que o diferencia de outros tipos de jornalismo e que confere legitimidade à sua prática.

O grande marco da consolidação da produção noticiosa de revistas brasileiras pode ser atribuído ao surgimento da revista O Cruzeiro, em $1928^{19}$. Ela é seguida por uma série de publicações feitas nos anos seguintes como a revista Manchete, nos anos 50 e a Realidade, lançada em 1966. A revista Visão, outro marco importante, é lançada em 1952 e a Veja em 1968. Também no Brasil, há uma grande fixação deste modelo de revista informativa, cuja característica diferenciadora é justamente informar a partir de uma visada interpretativa em torno dos acontecimentos.

Sendo interpretativa em sua essência, a produção revisteira noticiosa aprofunda, em determinados aspectos, as características de construção temporal que elencamos anteriormente. No que concerne à própria atualidade é bastante óbvia a ideia de que

\footnotetext{
${ }^{17}$ No século XVIII surge, em Londres, um novo formato revisteiro que foi chamado de Magazine, nome que foi dado baseado no fato de que, assim como as grandes lojas comerciais, essas revistas também possuíam uma grande variedade de artigos para entreter toda a família (THOMPSON, 1995: 231-234).

${ }^{18}$ Fundada em março de 1923 por Henry Luce e Briton Hadden, ela inspirou publicações como a Life, a Newsweek e a U.S.News \& World Report que, juntas, dominam o setor de revistas semanais do mercado norte-americano. Também no Brasil, foi uma influência fundamental da produção noticiosa de revistas como, por exemplo, no caso da Veja. Segundo Gazzotti (1999: 08), inicialmente esta "seria um semanário semelhante a Time, Look ou Life e terminou editada com um projeto gráfico inspirado em Newsweek".

${ }^{19}$ No Brasil, as revistas começam a ser publicadas somente no século XIX, com o lançamento de $A s$ Variedades ou Ensaios de Literatura, na Bahia, em 1812. A maioria das revistas brasileiras que surgirão até os primeiros anos do século XX terá, no entanto, um caráter mais literário do que propriamente informativo. Como pontua Sodré (1999: 297), "nelas é que irão se refugiar os homens de letras, acentuando a tendência do jornal para se caracterizar definitivamente como imprensa; as revistas passarão, pelo menos nessa fase, por um período em que são principalmente literárias, embora também mundanas e, algumas, críticas".
} 
uma revista não lida com o evento noticiado da mesma forma que outros tipos de veículos informativos que tem uma periodicidade diária ou em "tempo real". Trata-se do fato bem simples, como coloca Scalzo (2003: 41) de que "não dá para imaginar uma revista semanal de informações que se limita a apresentar para o leitor, no domingo, um mero resumo do que ele já viu e reviu durante a semana. É sempre necessário explorar novos ângulos, buscar notícias exclusivas, ajustar o foco" ${ }^{20}$.

E é por isso que alguns autores colocam este direcionamento para o futuro (prognósticos) e para o passado (origens e antecedentes) no interior da própria definição do conceito de jornalismo interpretativo. Para Luiz Beltrão, por exemplo, o jornalismo interpretativo tem a função de ampliar a informação dada pela notícia de forma que, "o imperativo do público", neste caso, "concentra-se então na vontade de conhecer a gênese da notícia e, igualmente, o prognóstico sobre seus efeitos... A realidade não estará apresentada plenamente se não conjuga o pretérito com o porvir". Na reportagem interpretativa "é necessário esquadrinhar sua entranha, procurando seus antecedentes melhores, e projetar numa visão futura, formulando um prognóstico atilado, sóbrio e inteligente, para não cair em demasias subjetivas" (BELTRÃO, 1976: 51).

Se isso pode ser ocasionalmente encontrado em outros tipos de jornalismo, no que concerne à imprensa interpretativa é sempre esperado que o sentido do evento relatado seja construído através de uma amplificação do fato para o passado e para o futuro, de forma que sejam mostrados antecedentes, origens e analogias, bem como consequências e desdobramentos. Mais do que uma característica deste tipo de imprensa, estamos mesmo diante de um aspecto ligado à temporalidade que a diferencia de outros tipos de produção noticiosa.

É por este motivo que Antunes e Vaz colocam que a atualidade no jornalismo de revista não está tanto ligada a irrupções de acontecimentos, mas sim, a tramas "que se precipitam sobre o universo midiático articuladas como uma 'malha' de pequenas e (quase) invisíveis narrativas que irrigam a vida social" (ANTUNES e VAZ, 2006: 52). A semantização do evento, dentro desta perspectiva, está sempre sujeito a este direcionamento temporal estendido.

É a partir disso que podemos constatar que a construção temporal envolvida no jornalismo não diz respeito tanto à atualidade em si, mas sim, a um presente da ação social, como sublinha Franciscato (2003: 285). E isso significa assumir, de uma maneira

\footnotetext{
${ }^{20} \mathrm{E}$ assim, "nas redações de jornais ou de telejornais, quando acontece um terremoto, por exemplo, tudo treme. Nas revistas, a redação (...) treme bem menos. Se for para falar do terremoto, será necessário descobrir o que ninguém sabe sobre ele, explicá-lo de forma diferente". É como se a notícia devesse "durar mais nas mãos do leitor", de forma que a leitura forneça informações extras - para além, mas correlatas - do fato noticiado.
} 
ampla, que o presente é uma construção social, de forma que os conteúdos compartilhados pelo jornalismo dizem respeito a uma experiência temporal discursiva relacionada a "um sentido partilhado socialmente resultante da atuação de atores sociais no ambiente - uma construção, por indivíduos e instituições, de concepções e produtos simbólicos ou de estruturas carregados de uma temporalidade do presente".

Este presente social deve ser entendido, portanto, como "um tempo de referência da ação coletiva", de forma que o jornalismo, ao rodear a sociedade de um presente social contínuo, oferece um tipo de conteúdo que é "bastante novo para que nos impressione e bastante velho para que possamos conhecê-lo e comentá-lo" (GOMIS apud FRANCISCATO, 2003: 336).

Outros autores preferem utilizar o termo continuum social para explicitar este funcionamento. Karam (2005: 78), por exemplo, coloca que a temporalidade expressa pelo jornalismo "é resultado de valores afirmados ao longo da história", de forma que ele possa abarcar o "reconhecimento dos conceitos, que expressam palavras e mundo concreto, legitimado também pela linguagem", constituindo-se, portanto, a partir de valores.

Essas problemáticas trazidas por estes autores remetem também a um outro aspecto da semantização do fato efetuada pela imprensa que não pode ser ignorado. Ele diz respeito não apenas às características específicas das construções temporais envolvidas neste tipo de jornalismo, mas sim, às pré-determinações de sentido que necessariamente estão presentes no processo evenemencial da produção noticiosa.

Para que possamos discutir este aspecto, precisamos ter em mente que, como sublinha Foucault (1996: 22-23), há sempre determinados desníveis entre os discursos, de forma que alguns deles se apresentam como meramente efêmeros, como relatos que "se dispersam e que desaparecem", como coisas que "'se dizem' ao correr dos dias e das relações, discursos que se esquecem no próprio ato que lhes deu origem”. Há, no entanto, um outro nível de discursos, estes mais fundamentais, que, ao contrário dos anteriores, dizem respeito a narrativas maiores que se repetem incessantemente e que fornecem o conteúdo dessas estórias mais efêmeras.

Trata-se de discursos que "estão na origem de certo número de novos atos de fala, atos que os retomam, os transformam ou falam deles, numa palavra, os discursos que, indefinidamente e para além da sua formulação, são ditos, ficam ditos, e estão ainda por dizer" (FOUCAULT, 1996: 22). Eles ajudam a semantizar a irrupção do novo, de forma que o que é dito é sempre acompanhado por estruturas de pensamento 
que já estão dadas. Visto sob este aspecto, "o novo não está naquilo que é dito, mas no acontecimento do seu retorno" (FOUCAULT, 1996: 26).

As ocorrências singulares trazidas pelo jornalismo, dentro dessa perspectiva, estão enquadradas por estas narrativas maiores que lhe fornecem a direção de entendimento e semantizam o fato relatado.

Sob a perspectiva dos discursos, é com este mesmo raciocínio que Teun Van Djik (1980: 248) chama a atenção para o fato de que a novidade presente nos relatos jornalísticos é somente "a ponta de um iceberg de pressuposições e, em consequência, da informação previamente adquirida”. E, neste sentido, a produção noticiosa envolveria "grandes quantidades de informação estruturadora, repetida e coerente, que sirva como base para ampliações mínimas e outras mudanças em nossos modelos do mundo".

Assim como Soares (2001: 30) estamos assumindo aqui a proposição de que "ao contrário do que se propaga, o jornalismo não está ligado à busca do 'novo todo dia', mas a algo que se repete e, ao se repetir, torna-se uma referência permanente àquilo que faz o comum de todos". E assim, portanto, é "redundância e novidade, repetição não do mesmo, mas do diverso que, diferente a cada vez, repete uma mesma estrutura". E assim, sob a ótica dos discursos, "as notícias interessantes não são aquelas absolutamente novas, mas as que repetem alguma coisa e, portanto, articulam-se a uma expectativa, dando continuidade à 'grande narrativa' continuamente em inscrição".

A temporalidade jornalística, portanto, não pode ser separada deste "tempo social", como coloca Franciscato, ou dessa "referência permanente àquilo que faz o comum de todos", nas palavras de Soares. É em torno desta construção do comum que gostaríamos de nos deter por um momento.

\section{A Construção Imaginária do Comum no Jornalismo}

As funções ligadas à produção noticiosa, vistas sob esta perspectiva, são bem mais vastas do que pode ser suposto à primeira vista. Ao se relacionarem com o tempo não necessariamente a partir da perspectiva do que é atual, embora este seja um dos pontos articuladores destas narrativas, mas principalmente a partir de algo que é repetidamente posto como inédito dentro de um universo de discursos, a produção noticiosa se estrutura mesmo, dentre outras coisas, a partir de construções imaginárias e de mediações em torno de um comum. Como coloca Gans (apud SOARES, 2001: 26), a noção de que a função da imprensa é a de informar o público deveria ser substituída por um conjunto mais amplo de ideias que incorporasse o fato de que "o objetivo primeiro 
das notícias é derivado do papel dos jornalistas como construtores da nação e da sociedade e como gerenciadores da arena simbólica. O objetivo mais importante das notícias, portanto, é fornecer à arena simbólica e à cidadania imagens abrangentes e representativas (ou constructos) da nação e da sociedade".

Sobre esse assunto, Stuart Hall (1993: 227) chama a atenção para o fato de que os medias estão entre as atividades que mais fortemente tem suas bases assentadas em uma assunção de um determinado consenso nacional. A partir de uma série de estratégias, é construída uma suposta ilusão de comum na medida em que "quando os acontecimentos são 'delineados' pelos media em enquadramentos de significado e interpretação, supõe-se que todos nós possuímos e sabemos igualmente como utilizar estes enquadramentos, que eles são extraídos fundamentalmente das mesmas estruturas de compreensão para todos os grupos sociais e públicos".

Também Saperas (1993: 12) remete a isso quando coloca que "os media atuam como construtores da realidade social, na medida em que dão visibilidade, enquadramento e consistência a um conjunto de matérias difundidas, quer no plano da informação, quer do entretenimento que passam a ser partilhadas por uma comunidade".

Se entendermos a imprensa como um dos atores que formam o espaço público, a noção de que ela remete ao comum passa a se relacionar mesmo com os modos em que as representações sociais circulam e adquirem corpo quando mediadas pela imprensa. Dentro da noção de que as constituições e reconstituições do espaço público devem ser olhadas à luz dos discursos circulantes - entendidos, como expõe Charaudeau (2006: 118), como "uma soma empírica dos enunciados com visada definicional sobre o que são os seres, as ações, os acontecimentos, suas características, seus comportamentos e os julgamentos a ele ligados" - as mídias funcionam mesmo como uma das formas de publicização do comum ${ }^{21}$.

Nesta linha, Charaudeau (2006) chama a atenção para o fato de que as representações sociais possuem, primordialmente, três funções que são: a organização coletiva dos esquemas de valores (que diz respeito aos conjuntos de pensamento normatizados pertencentes a uma coletividade), a exibição dessas características e a encarnação delas em figuras significativas, de modo que os valores dominantes (que podem se constituir em um conjunto de elementos ambivalentes) possam determinar o jogo das exclusões e das fronteiras.

\footnotetext{
${ }^{21}$ Estamos assumindo aqui que a imprensa é um dos atores envolvidos neste jogo e não o único. Como bem coloca Charaudeau (2006: 120), "não podemos concordar com aqueles que deixam transparecer que as mídias modernas se apoderam do espaço público para transformá-lo. As mídias são apenas uma forma de publicização. Sua ação é participar do que constitui, desconstitui, transforma o espaço público, no quadro do contrato de informação midiático".
} 
E desta forma, o jornalista como um produtor de enunciação tem a sua esfera de atuação sempre circunscrita a um contrato de comunicação midiático que se baseia em uma relação de ressonância: "cada um dos parceiros só pode sintonizar provisoriamente com o outro pelo viés de representações supostamente compartilhadas, as quais, levadas pelos discursos, circulam por entre os membros de uma determinada comunidade cultural" (CHARAUDEAU, 2006: 125).

Como coloca Sodré (2009: 69),

habituados que estamos em consumir o discurso informativo como uma objetivação dos fatos da atualidade cotidiana, deixamos de perceber que ali se constitui igualmente uma narrativa das práticas humanas, cuja função maior é chamar a atenção da coletividade para o modo como tais práticas se organizam ou devem organizar-se dentro de uma delimitação temporal, de uma periodização.

Este comum trazido pelos discursos circulantes tem na imprensa, portanto, um de seus meios privilegiados de mediação.

Ele está relacionado mesmo, com o fato de que as mídias têm como efeito primeiro o ato de trazer à visibilidade (GOMES, 2003: 75). E isso significa algo muito mais profundo do que somente mostrar um fato: "trazer à visibilidade é (...) simplesmente mostrar o mundo do ponto em que ele deve ser visto e esse ponto, por si mesmo, já é disciplinar: a educação da visão pela determinação do visível”. É a partir deste ponto de convergência entre os discursos e as disciplinas ${ }^{22}$, que o jornalismo constrói certo comum, na medida em que "os jornais, as notícias, procedem por redundância, pelo fato de nos dizerem o que é 'necessário' pensar, reter, esperar, etc. A linguagem não é informativa nem comunicativa, não é comunicação de informação, mas - o que é bastante diferente - transmissão de palavras de ordem" (DELEUZE e GUATTARI apud GOMES, 2003: 65).

E dentro dessa perspectiva, podemos ampliar a noção de prognóstico que estava posta anteriormente como um dos valores da imprensa. Ele não diz respeito apenas a seu relacionamento com um tempo narrativo ou com uma característica diferenciadora de um tipo específico de jornalismo, mas está relacionado mesmo a essa tomada disciplinar que ronda os textos noticiosos a todo o momento.

Estando sempre ancorado em um comum, o processo evenemencial pressupõe mesmo esse chamado aos significados socialmente compartilhados, de forma que a construção temporal das notícias está mesmo sempre assentada em repetições de discursos que se mostram sob novos eventos.

\footnotetext{
${ }^{22}$ Como coloca Gomes (2003: 103), "onde quer que haja discurso há palavras de ordem, a disciplina e o controle com que ele alimenta e dos quais se alimenta. Por todo esse espaço, a todo tempo, enuncia-se o visível e, portanto, o vivível".
} 
Isso posto, podemos voltar a nosso objeto de estudos principal e nos perguntar $o$ que pode a História nos dizer acerca da construção imaginária do tempo e da construção imaginária do comum.

Que o passado se configure como uma das fontes do comum - especialmente ligado às demandas de construções identitárias - é um assunto que já foi trabalhado por muitos autores e pode ser resumido por uma máxima que envolve uma circularidade fundante: "quem somos depende de quem fomos" e, mais do que isso, "quem pensamos que fomos depende de quem pensamos ser" (BURKE, 1995: 93). Se preferirmos as palavras de Pollak (1989: 3), poderemos dizer que o passado, "ao definir o que é comum a um grupo e o que o diferencia dos outros, fundamenta e reforça os sentimentos de pertencimento e as fronteiras sócio-culturais", de forma que diversos processos e atores atuam nesta constituição de uma memória do que é comum.

Essas construções do passado dizem respeito mesmo a objetivações de discursos fundantes na medida em que, de uma forma geral, atuam não só como um fator de coesão dos grupos, mas como um organizador importante das relações sociais, na medida em que marcam, de um lado, o lugar respectivo e a complementaridade entre os grupos e as instituições sociais e, de outro, as oposições irredutíveis, fornecendo, assim, quadros de referência. Deste modo, as remissões ao passado "sem serem o único fator aglutinador, são certamente um ingrediente importante para a perenidade do tecido social e das estruturas institucionais de uma sociedade" (POLLAK, 1989: 11). E isso acontece, fundamentalmente, porque o passado legitima. Ocupando sempre um lugar importante nos sistemas de educação pública, como coloca Hobsbawm (2005: 288), "toda história é história contemporânea disfarçada".

O passado sempre foi um poderoso articulador de sentidos, ligado a uma construção do tempo e a uma remissão ao comum. Em todas as épocas históricas nós podemos encontrar exemplos que mostram como ele tem sido sistematicamente utilizado como um importante recurso para legitimar determinadas questões e determinadas demandas do tempo presente ${ }^{23}$.

Uma vez que "ser membro de uma comunidade humana é situar-se em relação ao seu passado (ou da comunidade), ainda que seja apenas para rejeitá-lo", o passado se

\footnotetext{
${ }^{23} \mathrm{E}$ isso a tal ponto que os usos do passado com objetivos políticos surgiram antes mesmo que fossem registrados os primeiros estudos sistemáticos a respeito do que posteriormente seria chamado de ciência histórica. É neste sentido que Seters (2008), por exemplo, comenta o fato de que civilizações como os hititas já exploravam o decorrido com finalidades didáticas relacionadas, principalmente, com o oferecimento à nobreza de exemplos de bom comportamento e à legitimação do poder real (tanto através da descrição das façanhas do rei, quanto para justificar ações políticas extraordinárias e pregar a continuação dos privilégios reais), antes mesmo de um registro sistemático de seu passado.
} 
torna um componente permanente da consciência humana e uma dimensão não desprezível da instituição de valores e outros padrões sociais (HOBSBAWM, 2005: 22).

O passado, dentro dessa perspectiva é uma fonte importante de informações estruturantes que funcionam como essas narrativas que são incessantemente repetidas dentro de novos eventos. Ele diz respeito, ao mesmo tempo, a uma espécie de conjunto de inventários de discursos e a uma forma de se olhar para o futuro em busca de prognósticos. Mais do que isso, como coloca Hobsbawm (2005), mesmo para sociedades nas quais o decorrido é visto como dessemelhante ao atual, o passado ainda serve como uma fonte de justificação para determinadas imagens de mundo.

Para estudarmos como esse processo ocorre, iremos remeter a duas questões. Primeiramente, nos debruçaremos sobre a questão da construção do tempo e, mais especificamente, a partir do modo como o passado se articula ao presente e ao futuro, procuraremos investigar o que a história pode contribuir para um reforço da temporalidade jornalística - ou, em outras palavras, o que pode a história nos dizer acerca da contemporaneidade e do futuro. Em seguida, a partir da exploração do conceito de lugares de memória, investigaremos como a história se constitui como um inventário de discursos ligado às práticas representacionais a partir das quais nós fazemos ver o comum.

\section{O que pode o passado nos dizer acerca do comum, do presente e do futuro?}

\subsection{A inscrição do presente e do futuro no passado e a relação com as narrativas jornalísticas}

Já Aristóteles, em sua Retórica, atestava o valor do passado enquanto um poderoso recurso argumentativo de ordem comparativa para determinadas questões do tempo presente. Ao discorrer sobre o convencimento através do Exemplo, o autor destaca que ele pode ser manipulado a partir de duas variedades: ou como menção dos fatos passados (através de dados históricos de conhecimento geral) ou na invenção dos fatos pelo orador (tais como nas fábulas ou nos paralelos ilustrativos). Aristóteles (2007: 121) sublinha, no entanto, que, embora as fábulas tenham a vantagem de ser comparativamente fáceis de inventar, "será mais valioso que o orador político o faça por citação do que por acontecimentos factuais, pois o futuro será tal como foi o passado".

Esta questão - ligada à tentativa de demonstrar o futuro tal como foi o passado no entanto, fica um tanto mais complexa se pensarmos que, embora os usos do passado sempre tenham existido, eles nem sempre foram idênticos. Não podemos nos esquecer de que a forma como foram entendidas as correlações entre o atual e o decorrido, bem 
como a maneira pela qual a história foi entendida como uma referência ao comum mudaram ao longo do tempo.

Para que possamos entender a forma pela qual o jornalismo usa a História - ou, em termos mais precisos, como é feita a inscrição do fato jornalístico dentro da rede de significações sociais possibilitada pelo recurso ao passado, de modo que ele seja reintegrado em um conjunto de significados já estabelecidos - precisamos ficar atentos a essa ruptura que diz respeito, em um espectro amplo, ao que as sociedade esperam obter de seu passado.

Reinhart Koselleck (2006) - a partir do estudo de textos nos quais a experiência temporal se manifesta à superfície da linguagem e reportam a relação entre um determinado passado e um determinado futuro - atesta a emergência de um sentido de passado (e, por conseguinte, de expectativas de futuro) original a partir do advento da Modernidade. Segundo este autor, até o século XVIII era bastante comum que a História fosse vista como a somatória de diversos eventos que, em conjunto, forneciam a noção de uma história múltipla, com suas narrativas particulares e seus sentidos próprios. A partir deste período, no entanto, fica cada vez mais em voga o uso da História como a ideia de um processo que abraça essas diversas histórias em um único singular coletivo ${ }^{24}$.

O autor propõe que "se as histórias (no plural) guardavam a sabedoria acumulada pelos exemplos do passado para servir de guia à conduta presente, evitando a repetição dos erros e estimulando a reprodução do sucesso", a História como um singular coletivo "tornou-se uma dimensão inescapável do próprio devir, obrigando toda

\footnotetext{
${ }^{24}$ Essa mudança na significação da palavra "História" precisa ser entendida em seu contexto dentro da língua alemã, que possui dois nomes para designar o termo. "Historie" designa a narrativa de algo acontecido. Já "Geschichte" reporta a série de ações cometidas ou sofridas. O que Koselleck atesta é um esvaziamento do primeiro termo e uma utilização cada vez mais frequente do segundo, nomeando tanto o acontecimento quanto o seu relato. Marcelo Jasmin, em sua apresentação ao livro de Koselleck, explica muito bem essa ideia quando afirma que "se até meados do século XVIII o termo história [Historie] era usado no plural para designar as diversas narrativas particulares e descosidas entre si que a tradição historiográfica acumulara (a história da guerra do Peloponeso, a história de Florença, etc.), Koselleck sustenta que, a partir daquela época, é cada vez mais frequente o uso do termo História [Geschichte] no singular para designar, de modo confluente, tanto a sequência unificada de eventos que constituem a marcha da humanidade, como o seu relato (a História da civilização ou dos progressos do espírito humano). A essa 'singularização' semântica da História, que expressa a inclusão de toda a humanidade em um único processo temporal, corresponde a sua transformação em objeto de teorias políticas e filosofias que imaginam poder apreender o passado, o presente e o futuro como uma totalidade dotada de sentido previamente definido. É a partir dessa mutação de longa duração que se pensará a história como um processo inexorável de progresso (...)". Desta forma, "o termo história é convertido em instrumento normativo da luta política e será objeto de disputa entre proposições mais ou menos revolucionárias que compreendem a si mesmas como intérpretes fiéis dos verdadeiros propósitos desse processo universal" (JASMIN, 2006: 11).
} 
ação social a assumir horizontes de expectativa futura que a inscrevam como um desdobramento consoante com o processo temporal" (JASMIN, 2006: 11).

Se é a determinação da distinção entre experiência e expectativa que marca de forma mais contundente o que pode ser conceitualizado como "tempo histórico", é justamente a mudança nesta esfera da vivência da temporalidade que marca a alteração na relação entre passado e futuro também na sequência das gerações históricas. Se os antigos costumavam experimentar o tempo como a afirmação de um "sempre o mesmo", a novidade erguida pela Modernidade é justamente o advento de um futuro cada vez mais desafiador, que altera a relação imediata com as experiências e as tradições consagradas pela História.

Muito embora isso possa ser atestado a partir de diversas expressões semânticolinguísticas, um dos exemplos mais expressivos deste deslocamento, para Koselleck está nas sucessivas reterritorializações do velho topos ciceriano de que a História é mestra da vida (Historia Magistra Vitae). Isso porque, o valor semântico dessa fórmula teria variado consideravelmente ao longo do tempo, ainda que tenha conservado uma mesma forma verbal. Ao longo do tempo, ela recebeu tanto significações relacionadas à procura de regras históricas gerais quanto à rejeição de quaisquer generalizações.

A formulação original de Cícero remete ao aproveitamento perene do conteúdo da experiência adquirida e, no contexto da oratória, a um inventário de exemplos que confere imortalidade à História. "Assim, a História seria um cadinho contendo múltiplas experiências alheias, das quais nos apropriamos com um objetivo pedagógico; ou, nas palavras de um dos antigos, a história deixa-nos livres para repetir sucessos do passado, em vez de incorrer, no presente, nos erros antigos" (KOSELLECK, 2006: 42).

Embora tenha se ligado à figura de Cícero e, posteriormente, incorporada por diversos outros autores como Tito Lívio ${ }^{25}$ e Tácito, os contornos gerais desta fórmula são anteriores e já Tucídides (1987) afirmava que: "será suficiente para mim (...) se essas minhas palavras forem julgadas úteis para entender claramente os eventos que aconteceram no passado e que (a natureza humana sendo o que é) irão, em algum momento ou outro, da mesma forma, se repetir no futuro".

Muito embora essa fórmula tenha perdido força durante a experiência histórica cristã, na medida em que a autoridade da Bíblia deveria suprimir os exemplos da História pagã, muitos apologetas do cristianismo ainda faziam referência a este topos.

\footnotetext{
${ }^{25}$ Tito Lívio (2001: 207) escrevera que "o que principalmente há de são e fecundo no conhecimento dos fatos é que consideras todos os modelos exemplares, depositados num monumento, em plena luz: daí colhes para ti e para o teu estado o que imitar; daí evitas o que é infame em sua concepção e em sua realização".
} 
Mesmo que relegada a um segundo plano em relação às histórias que eram legitimadas por seu conteúdo religioso, a parte profana da experiência humana ganhava ainda ressonância em pensadores como Beda $^{26}$ (672-735) e Melanchton (1497-1560). Assim, para estes autores, a concepção de historia herdada da Antiguidade permanece presente, só que, desta vez, associada a uma experiência histórica cristã, baseada fortemente nas profecias e nas ideias de salvação eterna. Não obstante isso, o topos ciceriano continua presente, na medida em que ainda permanece a noção de que é possível delinear linhas de ação para o futuro a partir do passado.

Com Maquiavel, essa orientação novamente esvazia seu aspecto teológico e, como em Cícero, se rearticula para objetivos políticos e práticos. Trata-se mesmo de uma visão de História como exempla que encontrará ecos em diversas concepções de História durante o Renascimento. A forma como Maquiavel constrói sua engenharia do poder é amplamente baseada em exemplos de políticos de antigamente, adotando, portanto, uma concepção cíclica da História. Para ele, os fenômenos ressurgem, permitindo que seja feita uma espécie de previsão do futuro, baseada no comportamento dos grandes líderes de sucesso. Assim, Maquiavel escreve no capítulo VI de $O$ Príncipe que "os homens trilham quase sempre estradas já percorridas. Um homem prudente deve assim escolher os caminhos já percorridos pelos grandes homens e imitá-los; assim, mesmo que não seja possível seguir fielmente este caminho, nem pela imitação alcançar totalmente as virtudes dos grandes, sempre se aproveita muita coisa" (MAQUIAVEL, 1996: 51).

Para Maquiavel, as vontades e as paixões humanas, assim como as forças da natureza, não têm história sendo, por isso, atemporalmente válidas. De forma complementar, seu pensamento também toma o caráter do homem como o grande elemento explicativo da História, modelo pelo qual se poderia chegar ao seu conhecimento elementar e elaborar, desta forma, os moldes para a previsão e para a ação política. Resumindo, sua filosofia da História e as questões modelares de sua engenharia do poder estão em dependência direta com a sua exposição da natureza humana e, da mesma forma, só encontram coerência se admitirem, em termos do que define o homem, que o presente foi tal como o passado.

De fato, a formulação inicial da Historia Magistra Vitae encontra diversos ecos até o século XVIII a partir de uma variada gama de formulações. Poderíamos citar, por

\footnotetext{
${ }^{26}$ Beda escreve na sua História Eclesiástica do Povo Inglês que "pois quando a História relata coisas boas dos bons, o ouvinte solícito é instigado a imitar o bem, e quando lembra as coisas más dos maus, mesmo assim o pio e religioso ouvinte e leitor é estimulado a evitar o que é prejudicial e perverso, e com maior estímulo é impelido a realizar as coisas que percebe serem dignas" (apud KOSELLECK, 2006: 330, nota 12).
} 
exemplo, a definição de labor histórico de Johannis Kahl, para quem o historiador deveria narrar as coisas que sirvam de exemplos para os agentes. Segundo este autor: "Mas as coisas realizadas desde o começo do mundo, o bom e grande Deus quis que fossem descritas para mais tarde, pelos exemplos de todos os séculos, apresentar aos olhos dos novos a forma segundo a qual pudéssemos deliberar sobre a feliz recuperação da decadente República” (KAHL apud KOSELLECK, 2006: 331, nota 16).

A expressão ganha, ainda, certa ornamentação barroca na formulação da enciclopédia de J. H. Alsted, para quem: "a História é o teatro da totalidade das coisas, o espelho do tempo, o tesouro da demonstração, o olho da sabedoria, e espelho da vida, ignorância e estultice, o princípio da prudência, o guarda e arauto das virtudes, a tese da malícia e da improbidade, o vale da verdade, a metrópole da sabedoria e um tesouro para toda a posteridade" (J. H. ALSTED apud KOSELLECK, 2006: 331, nota 17). Frederico, o Grande, chega a escrever em suas memórias que "no palco do mundo é encenada sempre a mesma comédia ou a mesma tragédia, o que muda são apenas os personagens" (apud KOSELLECK, 2006: 332, nota 24).

Embora houvesse, durante esse período, alguns opositores a esta fórmula, de uma maneira geral, a validade do topos era atestada por um mesmo solo de premissas envolvendo diversos pensadores a respeito desta questão. Todos eles remetiam a uma compreensão de que as possibilidades humanas estavam contidas em um continuum histórico de validade geral. Isso quer dizer que os pressupostos para este aperfeiçoamento moral e intelectual que a história ofereceria eram compreendidos como praticamente os mesmos durante todo o período. Os acontecimentos simplesmente não eram entendidos como inéditos, na medida em que eles não possuíam força suficiente para apagar ou suplantar os eventos que se repetem de forma sempre igual.

Como expressão da mudança nesta linha mestra que regia o topos da História como mestra da vida - fruto de um movimento que reorganiza a própria relação entre passado e futuro -, Koselleck chama a atenção para a observação de Tocqueville, quando este diz que, apesar de os rumos da revolução que ele descreve não estarem encerrados, a nova situação não se parece com qualquer outro evento que ele tenha testemunhado: "eu percorro os séculos até a mais remota Antiguidade, mas eu não encontro paralelos com nada que pareça ao que está acontecendo diante dos meus olhos: como o passado deixou de lançar luzes ao futuro, a mente do homem vagueia na obscuridade" (TOCQUEVILLE, 1863: 408).

A partir de constatações como esta, o topos em questão se esvazia até a sua desfiguração em direção a diferentes sentidos que mostram outras relações com o 
tempo. Uma das expressões mais significativas deste movimento está na fórmula de Droysen segundo a qual a História só pode conhecer a si própria. Em outras palavras, isso significa que "acima das histórias está a história, como resumiu posteriormente Droysen esse processo" que transforma a História em um singular coletivo (KOSELLECK, 2006: 49).

A partir da emergência da filosofia da História que a compreendia singularmente como um todo unitário, há uma quebra na correspondência imediata entre passado e futuro tal como ela poderia ser concebida pela expressão ciceriana. Uma vez que a história como um todo é transformada em um evento único e singular do gênero humano, a relação entre a experiência e a expectativa, portanto, se articulará, a partir daí, de uma forma inteiramente outra, pois:

a perfídia da razão impede que o homem aprenda diretamente a partir da História, impelindo-o ao seu destino de forma indireta. Trata-se aqui da consequência progressiva que nos leva de Lessing a Hegel. 'O que a experiência e a história nos ensinam é que os povos e os governos jamais aprenderam algo a partir da história, assim como jamais agiram segundo ensinamentos que dela fossem extraídos'. Ou, então, nas palavras de um experiente contemporâneo de Hegel, o abade Rupert Kornmann: 'é destino dos Estados, assim como do homem, tornar-se sábio apenas quando já passou a oportunidade de sê-lo’ (KOSELLECK, 2006: 55).

À medida que as ideias de futuro e de processo tornam o passado dessemelhante ao presente, há o engendramento de um mecanismo de rearticulação do velho topos: a função da História deixa de estar ligado ao objetivo de instruir e se religa à pretensão de julgar. A História deixa de ser somente um inventário de exemplos, para funcionar também como um campo de conhecimento para a situação presente a partir de parâmetros completamente novos, uma vez que a temporalidade se articula como continnum.

Como diz Paul Ricoeur (2007: 315), “aplicado doravante à história enquanto tal, o conceito de experiência, qualificado pela modernidade, recobre as três instâncias do tempo", de forma que vincula o passado advindo, o futuro que se espera e o presente como o tempo vivido. "O que é declarado moderno por excelência, é esse caráter onitemporal da história”. Além disso, também como uma particularidade moderna, a história se reveste de uma significação antropológica inteiramente nova: "a história é a história da humanidade e, nesse sentido, história mundial, história mundial dos povos. A humanidade se torna simultaneamente o objeto total e o objeto único da história, ao mesmo tempo em que a história se faz coletivo singular" (RICOEUR, 2007: 315).

Isso muda de uma forma marcante a maneira pela qual o passado era ligado ao futuro. A qualidade da mudança na percepção temporal ocorrida entre 1500 e 1800 - ou 
melhor, as mudanças dos padrões de entendimento em que variação e aceleração históricas puderam ser sentidas - pode ser descrita tomando-se como marcos inicial e final, respectivamente, as ideias de Lutero e de Robespierre.

Lutero interpretava a aceleração do tempo como um prenúncio de que a data do Juízo final estaria próxima. Ao verificar que "Deus, por amor aos escolhidos, abreviaria os últimos dias 'pois o mundo se apressava nesta direção (...) porque ao longo dessa década foi quase um novo século"” (KOSELLECK, 2006: 25), ele estava se referindo a compressão do tempo como prenuncio dos dias do Apocalipse. O passado e o presente eram sentidos como tempos iguais, na medida em que ambos significavam um prenúncio do fim dos tempos.

Trezentos anos a frente, Robespierre parece ter uma sensibilidade temporal inteiramente outra quando, no Discurso de 10 de Maio de 1793, declara que "é chegada a hora de conclamar cada um para seu verdadeiro destino. O progresso da razão humana preparou esta grande Revolução, e vós sois aqueles sobre os quais recai o especial dever de acelerá-la" (apud KOSELLECK, 2006: 25).

Isso porque "a providencial fraseologia de Robespierre não é capaz de dissimular que o horizonte de expectativa alterou-se em relação à situação inicial. Para Lutero, a abreviação do tempo é um sinal visível da vontade divina de permitir que sobrevenha o Juízo Final, o fim do mundo". Ao contrário, "para Robespierre, a aceleração do tempo é uma tarefa do homem, que deverá introduzir os tempos da liberdade e da felicidade, o futuro dourado. Ambas as posições, assim como o fato de que a Revolução derivou da Reforma, marcam o início e o fim do período de tempo aqui articulado" (KOSELLECK, 2006: 25).

$\mathrm{O}$ que muda entre um período e outro diz respeito às expectativas futuras. No primeiro momento, o futuro era indissociavelmente um elemento constitutivo da Igreja e dizia respeito sempre a um possível fim dos tempos. Neste sentido, o futuro era posto em suspensão, na medida em que permitia que a história da Igreja fosse identificada à história da Salvação. No período subsequente, a ideia de futuro é essencialmente diferente uma vez que este passa a ser integrado ao tempo. Aqui, é o Estado que se apropria do monopólio da manipulação do futuro e a noção de prognóstico substitui a ideia de profecia. "O prognóstico produz o tempo que o engendra e em direção ao qual ele se projeta, ao passo que a profecia apocalíptica destrói o tempo, de cujo fím ela se alimenta" (KOSELLECK, 2006: 32).

A ideia de processo engendrada pelos filósofos dos séculos XVIII e XIX nada mais é do que um desenvolvimento desta noção na medida em que "foi só com o 
advento da filosofia da história que uma incipiente modernidade desligou-se de seu próprio passado, inaugurando, por meio de um futuro inédito, também a nossa modernidade". Isso significa que ela estava embebida em um espírito que misturava política e profecia uma vez que "imiscuiu-se na filosofia do progresso uma mistura entre prognósticos racionais e previsões de caráter salvacionista, própria do século XVIII” (KOSELLECK, 2006: 35-36). É a partir da noção de prognóstico, portanto, que se pode pensar em uma característica própria da modernidade, na medida em que esse conceito é capaz de inscrever o passado no futuro.

A partir dos autores estudados, como podemos, então, responder á nossa pergunta inicial: o que o passado tem a nos dizer acerca do comum, do presente e do futuro?

A questão das significações do passado não pode ser dissociada - uma vez que a história não é meramente uma disciplina teórica e está correlacionada intimamente a práticas sociais - do problema que concerne ao o que as pessoas esperam obter deste passado. De acordo com Eric Hobsbawm, durante a maior parte do passado humano, supunha-se que ele tivesse a capacidade de nos dizer como uma sociedade qualquer deveria funcionar. O passado era mesmo o modelo para o presente e para o futuro.

Isso significa que o sentido do passado até o século XVIII - relacionado mesmo com a ideia de que os mais velhos eram sábios não na medida de sua experiência, mas a partir do fato de que eles eram um repositório da memória coletiva sobre o modo no qual as coisas deveriam ser feitas - direcionava os padrões para o presente ${ }^{27}$.

Curiosamente, esse direcionamento que tornava o presente similar ao passado não excluía, de forma alguma, que se pudessem absorver alguns tipos de inovação. Isso pode ser feito na medida em que "o vinho novo pode ser vertido, no que, pelo menos na forma, são velhos recipientes", ou seja, de forma que a "inovação possa ser formulada como não-inovação" (HOBSBAWM, 2005: 24). E isso se manifesta, por exemplo, em uma súbita redescoberta de alguma parte do passado esquecida ou a pregação de um retorno aos tempos do passado (os bons tempos do passado!) quando o modelo do presente se torna insatisfatório ou insuficiente. Nestes casos, a busca por estes passados remotos se identifica à inovação total e o passado evocado pode se tornar, muito

\footnotetext{
${ }^{27} \mathrm{O}$ passado, neste contexto, "tende a ser o tribunal de apelação para disputas e incertezas do presente: a lei é igual ao costume, sabedoria dos mais velhos, em sociedade iletradas; os documentos que consagram esse passado e que, com isso, adquirem certa autoridade espiritual, fazem o mesmo em sociedades letradas ou parcialmente letradas" (HOBSBAWM, 2005: 23). É neste sentido que, para fins normais, o passado representava "a chave para o código genético pelo qual cada geração reproduzia seus sucessores e organizava suas relações. (...) O termo 'Senado' como designação do setor sênior do Congresso dos EUA e de outros parlamentos é um registro dessa suposição" (HOBSBAWM, 2005: 37).
} 
facilmente, nos termos postos por Hobsbawm, "um artefato" ou, ainda, "uma fabricação".

É a este tipo de sentido do passado que Hobsbawm chama de "uso antiquado ou experiencial" da história: "o tipo que Tucídides e Maquiavel teriam reconhecido e praticado" (HOBSBAWM, 2005: 41). Koselleck também se refere a este tipo de relação do homem com o seu passado - ambos situando-o no período anterior ao século XVIII em que este serve como um guia de ação eficaz para o entendimento do presente, na medida em que se tratava, de uma maneira geral, de um tempo entendido como a repetição de um "sempre o mesmo".

A questão se torna potencialmente mais complexa quando o passado e o futuro deixam de ser vistos como tempos semelhantes, quando as ações do presente simplesmente não encontram precedentes, ou o passado se torna completamente inadequado para o entendimento das coisas, uma vez que a mudança não é somente inevitável como também desejada ${ }^{28}$. Esse sentimento, para Hobsbawm (2005: 41), de transformações rápidas, radicais e contínuas, era o tipo de sensação própria do final do século XVIII e, especialmente forte, a partir da segunda metade do século XX.

Isso apresenta uma série de dificuldades uma vez que determinadas inovações também exigem uma legitimação tal como a que pode ser fornecida pelo passado, em um período em que este parece deixar de poder ser tomado como mestre da vida. Isso se torna especialmente problemático na medida em que "a experiência básica dos últimos dois séculos foi a da mudança constante e contínua, que não pode ser assim considerada, exceto ocasionalmente, à custa de considerável casuísmo, como a aplicação constantemente necessária de princípios permanentes a circunstâncias que sempre mudam de modo um tanto misterioso" (HOBSBAWM, 2005: 30).

Não obstante isso, o passado continua a ser uma ferramenta analítica bastante útil para lidar com essa mudança constante, mesmo que os princípios pelos quais ele pode ser entendido tenham se modificado de forma drástica. Essa mudança no sentido do passado é fundamental para entendermos a novidade trazida pela modernidade na forma como experimentamos o tempo.

\footnotetext{
28 “Sabemos muito pouco sobre o processo que transformou as palavras 'novo' e 'revolucionário' (conforme empregados na linguagem publicitária) em sinônimos de 'melhor' e 'mais desejável', e nesse ponto há muita necessidade de pesquisas. Porém, parece que a novidade ou mesmo a inovação constante é aceita mais prontamente na medida em que se refira ao controle humano sobre a natureza não humana (...). Por outro lado, conquanto certas inovações sociopolíticas possam parecer atraentes a alguns grupos de seres humanos, pelo menos na visão prospectiva, as implicações sociais e humanas da inovação (inclusive inovações técnicas) tendem a encontrar maior resistência” (...) (HOBSBAWM, 2005: 29).
} 
O passado "se converte na descoberta da história como um processo de mudança direcional, de desenvolvimento ou evolução. A mudança se torna, portanto, a sua própria legitimação, mas com isso ela se ancora em um 'sentido do passado' transformado" (HOBSBAWM, 2005: 30). Em outras palavras, o mecanismo de mudança no sentido da História que surge a partir do século XVIII descrito por Koselleck é a nova forma de uso do passado e legitimação através dele que se adéqua a uma época em que a mudança se torna a regra e que o passado não pode simplesmente ser tomado como análogo ao presente.

Muito embora a teoria da História enquanto progresso e a afirmação de que existem leis na História tenham sido amplamente desacreditadas, elas marcam o início de uma consciência histórica que não se encontra, de modo algum, superada. Isso porque, até para a historiografia mais recente "o que legitima o presente e o explica não é o passado como um conjunto de pontos de referência (por exemplo, a Magna Carta), ou mesmo como duração (por exemplo, a era das instituições parlamentares), mas $o$ passado como um processo de tornar-se presente". Desta forma, "diante da realidade avassaladora da mudança, até mesmo o pensamento conservador se torna historicista" (HOBSBAWM, 2005: 30).

Com isso, modifica-se também a relação do passado com o futuro, uma vez que a História entendida como singular coletivo possibilita extrapolações mais ou menos sofisticadas que buscam pistas no processo de desenvolvimento dos acontecimentos no passado como forma de tentar delinear o que está por vir ${ }^{29}$. É com base nesta ordem de pensamentos que Hobsbawm pode atestar a aporia fundamental de que quanto mais embebidos estamos nos ideais de inovação e de mudança contínua, mais firmemente nos apoiamos na história para descobrir como essas alterações se darão.

Como bem coloca Hobsbawm (2005: 31), “esse procedimento pode ir desde o muito ingênuo - a visão do futuro como um presente maior e melhor, ou um presente maior e pior, tão característica das extrapolações tecnológicas ou antiutopias sociais pessimistas - até o intelectualmente muito complexo e intenso; mas, essencialmente, a história continua a ser a base de ambos".

\footnotetext{
${ }^{29} \mathrm{O}$ que Hobsbawm sugere neste trecho é o fato de que, indubitavelmente, a História deixou de ser vista como uma escatologia secular - seja através da ideia de um progresso universal interminável, seja como uma força com fins teleológicos (como era concebida nos séculos XVIII e XIX). Não obstante isso, esses processos ainda podem ser tomados como marco de início de nossa atual consciência histórica na medida em que, até hoje, tomamos como válida a ideia de que podemos "descobrir os padrões e mecanismos de mudança histórica em geral, e mais particularmente das transformações das sociedades humanas durante os últimos séculos de mudança radicalmente aceleradas e abrangentes. Em lugar de previsões ou esperanças, é isso que é diretamente relevante para a sociedade contemporânea e suas perspectivas (HOBSBAWM, 2005: 43).
} 
É a isso que também se refere Fernand Braudel (1992: 330-331) quando afirma que os historiadores podem ser invejados uma vez que podem recorrer a duas maneiras de escapar ao tempo presente: uma está no refúgio ao passado e a outra no evadir-se para o futuro. Para ele, de fato, foi "o que fizemos, nós, historiadores, bem antes que nascesse a moda da perspectiva, também dita futurologia. Nada mais cômodo, na verdade, para julgar o tempo presente".

Este sentido que dotamos o passado, no entanto, não exclui outras formas. "Podemos ainda ser obrigados a remontar ao passado, de certo modo análogo ao seu uso tradicional como repositório de precedentes ainda que agora fazendo nossa seleção à luz de modelos ou programas analíticos que nada tem a ver com ele" (HOBSBAWM, 2005: 32). De certa forma, a concepção do passado como uma continuidade coletiva de experiência não é de todo sepultada pela modernidade e, mesmo que este tipo de conhecimento acumulado tenha perdido muito de sua relevância, a hegemonia da forma de mudança histórica não exclui a persistência, em diversas outras circunstâncias, de outras formas de sentido do passado.

O que temos que ter em mente não é a substituição de uma forma por outra, mas sim, o surgimento de uma nova maneira de experiência do tempo a partir do momento em que as mudanças frequentes esgarçam até o ponto de ruptura as similaridades antes tidas como válidas entre o presente e o passado. O que antes era tido como um modelo de ação atemporalmente válido posto na forma de um repositório de exemplos, passa a ser também a própria expressão e justificação do devir, como uma forma de conferir a legitimidade de um precedente mesmo para coisas que parecem não possuir precedentes concretos.

Dentro desta perspectiva geral, podemos entender como as mídias (e, muito particularmente, a imprensa) articulam a significação do presente com o decorrido e com o porvir. Ao remeter a este comum posto pela História, o jornalismo está também conjurado com uma construção temporal que projeta determinadas expectativas em torno do que a história pode nos dizer acerca do presente e do futuro - expectativas estas que ultrapassam o trabalho jornalístico e dizem respeito mesmo aos modos pelos quais o homem imprime sentido ao mundo. Ou, em outras palavras, está articulado a este papel que a história atua dentro das sociedades - lugar este, que por sua vez, permite ou proíbe determinados pontos de união de sentido, como colocaria Certeau.

Se o processo evenemencial que constitui a notícia, conforme colocamos anteriormente, diz respeito a um mecanismo a partir do qual o fato bruto passa por um processo de semantização (ou edificação de um lugar de sentidos) a partir do qual há 
uma recontextualização do evento através da inscrição deste em uma rede de significações temporais, de forma o presente jornalístico está ligado a um continnum da ação social, o recurso à história é uma maneira eficiente de se mobilizar este conjunto de significados já estabelecidos.

E a partir dos subsídios teóricos trazidos pelos autores citados, podemos entender que esta semantização temporal pode acontecer de duas formas básicas. Assim como expõe Hobsbawm acerca da sociedade contemporânea, também no jornalismo podemos notar um cruzamento complexo entre as inscrições históricas que dizem respeito a um uso antiquado ou experimencial da História - ou seja, a partir dos quais um conjunto de referências do passado serve como modelos de inscrição que fornecem o molde e o entendimento para os eventos do presente e há a pressuposição de uma similaridade entre os dois tempos - quanto a partir de construções que articulam o presente como um passado em processo de se tornar atual e que se concentra nos possíveis desdobramentos futuros dos acontecimentos através de prognósticos.

Quando as narrativas jornalísticas estabelecem uma relação explícita entre uma crise do passado e um dilema do presente, como chama a atenção Edy (1999), esse uso experimencial da História funciona como um poderoso articulador de sentidos na medida em que esse jogo de similaridades entre o atual e o decorrido circunscreve não apenas a natureza do problema relatado, como também delimita uma série de julgamentos, como os agentes responsáveis pelo problema, as suas possíveis resoluções e os padrões através dos quais as soluções propostas podem ser normativamente julgadas.

Mais do que apenas uma construção de similaridades, essas aproximações funcionam mesmo como poderosos símbolos e ícones noticiosos, na medida em que fornecem as direções de entendimento em torno de um fato.

Trata-se de uma problemática que também pode ser estendida para os momentos em que há esta outra construção do tempo, que toma a forma de um passado que está em processo de se tornar presente. E isso porque, em narrativas jornalísticas deste tipo estão circunscritos não apenas os "modos a partir dos quais chegamos até aqui", mas, de uma maneira mais ampla, há a delimitação de quais aspectos (ou quais partes do passado) seriam relevantes para o entendimento de uma determinada temática. E, em última instância, esses pontos escolhidos são completamente arbitrários.

Como coloca Hannah Arendt (2007: 123), quando a ocorrência particular deriva a sua inteligibilidade de um todo (fornecido por um modelo de desenrolar dos fatos da história) há um problema fundamental relacionado ao fato de que podemos tomar 
qualquer hipótese e agir sobre ela "com uma sequência de resultados na realidade que não apenas fazem sentido, mas funcionam". É como se estivéssemos brincando com alguma espécie de jogo de escolha os pontos - pontos estes que serão escolhidos já em função de pré-julgamentos e de ideias a partir das quais se busca convencer. Mais do que isso, pontos que, ao serem colocado em uma ordem, farão sentido e delimitarão os contornos de entendimento em torno do relatado.

E “isso significa, de modo absolutamente literal, que tudo é possível”, na medida em que "qualquer ordem, qualquer necessidade, qualquer sentido que se queira impor fará sentido. Essa é a mais clara demonstração possível de que, sob essas condições, não há necessidade, nem sentido" absoluto (ARENDT, 2007: 125).

Esse mecanismo é expandido se pensarmos que, como colocamos anteriormente, o futuro é um dos tempos básicos da semantização dos fatos na imprensa interpretativa e, paradoxalmente, na maior parte das vezes, é a história que fornece os conteúdos para que essas projeções possam ser delineadas. É este jogo de escolha os pontos que muitas vezes articulam os prognósticos possíveis e, por conseguinte, estabelece um julgamento em torno das soluções propostas.

Trabalharemos mais detalhadamente em torno destas temáticas na análise do corpus recolhido. Por ora, gostaríamos de nos deter em um outro ponto que também diz respeito aos modos a partir dos quais o jornalismo remete a este comum trazido pela história: ele diz respeito à maneira pela qual o passado se constitui como um inventário de discursos ligado às práticas representacionais a partir das quais nós fazemos ver o comum. Diz respeito ao fato de que, ampliando algumas que trabalhamos anteriormente, podemos dizer que ao evocar a História invocando um comum, o jornalismo está fazendo remitência mesmo a um lugar de memória.

\subsection{O passado como um comum: os lugares de memória nos discursos jornalísticos}

Embora a questão da mobilização do comum efetuada pelas remissões ao passado já tenha sido tratada um pouco no tópico anterior, a amplidão desta problemática tem que passar necessariamente pela questão das representações ligadas aos lugares de memória. E esta noção diz respeito a um diagnóstico, feito por Pierre Nora, de que se nas sociedades tradicionais, baseadas na memória, o velho ideal era ressuscitar o passado; na sociedade contemporânea, o novo ideal se resume a representá-lo. Em outras palavras, se a memória é vida, a História é pura representação e é no interstício destas noções que se encontram os lugares de memória. É em torno 
desse conceito que conseguiremos delinear o modo como o jornalismo, ao evocar a História, invoca um inventário de discursos ligado ao comum.

Para o autor, a existência de lugares que cristalizam as memórias (tais como os museus e monumentos, bem como qualquer prática representacional do passado) significa, apenas, que "se a memória está constantemente em nossos lábios é porque ela não existe mais" (NORA, 1996a: 1). Os lugares de memória (lieux de mémoire) existem, neste sentido, porque não existem mais os meios de memória (milieux de mémoire), porque a memória deixou de ser parte da experiência cotidiana.

No que concerne à relação entre a memória e a História, os dois termos são tomados como antagônicos na medida em que a primeira é tida como parte da vida de uma sociedade e, como tal, sujeita a mudanças frequentes, além de extremamente vulnerável ao trabalho de manipulação e apropriação. A História, pelo contrário, é sempre um trabalho de reconstrução (extremamente problemático e incompleto) de uma coisa que não mais existe. Se a memória é sempre um fenômeno do presente, um laço que nos amarra ao eterno presente; a história é sempre a representação de um passado. A História, de certa forma, destitui do passado vivido a sua legitimidade, em um processo de desencantamento do mundo.

Desta forma, o que se costuma chamar de memória é, na verdade, História. "A necessidade de memória é a necessidade por História" (NORA, 1996a: 8). O uso da palavra "memória" é até mesmo autorizado, contanto que ela esteja advertidamente posta como a memória que foi transformada por sua passagem através da História, em contraste com a memória viva das sociedades tradicionais.

Uma das consequências desta memória historicizada é o fato de que, como ela está apartada das práticas sociais, ela é interiorizada como uma coação individual. Desta forma, "a resultante obrigação de lembrar faz de todo homem o seu próprio historiador" (NORA, 1996a: 10). Com isso, Nora se refere ao grande número de resgates do passado que emergem de diversos grupos e instituições sociais (associações profissionais, grupos minoritários, empresas, etc.). Paradoxalmente, a historicização do passado coloca as pessoas diante, portanto, de um imperativo de memória que ordena a todo o momento com a força de um mandamento: "lembre-se" ("Thou shalt remember").

Essa emergência do "lembre-se" foi, de certa forma, coincidente com a constatação da importância da memória para a formação dos indivíduos. Ela se torna uma demanda pessoal na medida em que traz consigo uma força coercitiva que diz respeito à descoberta das raízes ou do pertencimento a algum grupo que possa se tornar uma fonte de identidade. Trata-se de um fenômeno cada vez mais aprofundado na 
medida em quanto menor a vivência e a partilha das memórias coletivas, maior é o encargo do indivíduo nesta busca.

Este é, portanto, o destino ambivalente da memória coletiva que já se anunciava desde o nascimento do termo. Isso porque, como bem pontua Nora, "no final do século passado [século XIX], quando a sociedade rural entrou em colapso e o antigo equilíbrio social foi rompido, a memória se tornou uma questão central no pensamento filosófico com Bergson, no pensamento psicológico com Freud e na literatura autobiográfica com Proust". Estes seriam os grandes marcos do aprofundamento da passagem da memória vivida para a memória interiorizada: a partir destes autores que começa a ficar mais evidente o processo pelo qual "a memória se torna um assunto privado. Como resultado desta psicologização, o ser agora estabelece uma nova relação com a memória e com o passado" (NORA, 1996a: 11).

Ora, para que possamos ter a dimensão do que isso significa, precisamos ter em mente que Nora tem como referência o trabalho de Maurice Halbwachs sobre a memória coletiva.

Os escritos de Halbwachs são um ataque direto ás teses psicologizantes da memória, representadas na época, principalmente, pela figura de Charles Blondel. Segundo este autor, a memória individual não é só uma condição necessária, mas também suficiente para a recordação e para o reconhecimento das lembranças. A obra de Halbwachs - principalmente os livros Os Quadros Sociais da Memória e A Memória Coletiva - se estruturam contra esse argumento, ao postular que não só nós nunca nos lembramos sozinhos, como também o fato de que a memória se esvai quando nos afastamos do grupo que estava a ela ligado.

Neste sentido, não é senão "a partir de uma análise sutil da experiência individual de pertencer a um grupo, e na base do ensino recebido dos outros, que a memória individual toma posse de si mesma" (RICOEUR, 2007: 130). E isso porque a memória individual não é nada mais do que a memória formada pela vivência de uma pessoa em diversos grupos ao mesmo tempo. É a soma não redutível destas várias memórias coletivas que se alocam no ser e representam a sua parcela individual de experiência. Em outras palavras, a constituição da memória é, em cada indivíduo, uma combinação aleatória das memórias dos diferentes grupos nos quais ele sofre influência - e isso explicaria, em grande medida, porque as pessoas guardam memórias diferenciadas.

É neste sentido que, "poderíamos invocar um número enorme de lembranças muito originais de adultos, que se apresentam com tal característica de unidade, que 
parecem resistir a qualquer decomposição", mas, no entanto, "para esses exemplos, poderíamos sempre denunciar a mesma ilusão". Essa ilusão se refere ao fato de que a influência destes diferentes grupos só encontra ressonância no próprio interior do indivíduo e, desta forma, ele participa, portanto, de dois tipos de memórias, sendo a individual, uma mera combinatória das inúmeras coletivas.

Assim, as memórias não estariam materializadas nos corpos ou mentes, mas na sociedade circundante, através dos diversos grupos que a compõe. E isso se dá na medida em que, para recordar, os indivíduos precisam utilizar convenções sociais que não são criadas por eles - afinal, "o funcionamento da memória individual não é possível sem esses instrumentos que são as palavras e as ideias, que o indivíduo não inventou, mas toma emprestado de seu ambiente" - e também de outras pessoas que possam legitimar suas próprias recordações - "para evocar seu próprio passado, em geral a pessoa precisa recorrer às lembranças de outras" (HALBWACHS, 2006: 72).

Muito embora Maurice Halbwachs com seu conceito de memória coletiva se afaste destas noções de memória interiorizada e como dever individual, de certa forma, no entanto, o autor parece reconhecer certo avanço da memória histórica sobre a memória coletiva quando se preocupa em estabelecer os parâmetros a partir dos quais as duas podem ser diferenciadas. Se o autor estabelece uma relação íntima entre a memória individual e a memória coletiva, de maneira que as duas se interpenetram, a memória histórica possui uma relação muito mais exterior.

A história, para Halbwachs, é entendida como a representação de um passado "sob uma forma resumida e esquemática", como "o epitáfio dos fatos de outrora, tão curto, geral e pobre de sentido como a maioria das inscrições que lemos sobre os túmulos. A história parece um cemitério em que o espaço é medido e onde a cada instante é preciso encontrar lugar para novas sepulturas" (HALBWACHS, 2006: 74). Essas informações frias da História só adquiriam um sentido mais denso se puderem ser correlacionadas a alguma vivência pessoal - da própria pessoa ou de seu grupo mais imediato ligado pelos vínculos entre gerações. É somente através do vínculo geracional que se pode efetuar a transição entre a memória aprendida e a memória vivida.

Assim, a História surge no exato ponto em que a tradição termina, no instante em que a memória social se decompõe ou se esgarça até o ponto de ruptura. Mais do que isso, quando a memória de uma sequência de acontecimentos perde o seu suporte de um grupo, quebra-se um elo fundamental da memória, pois esta só pode ser exercida na medida em que ainda existam indivíduos que participaram destes eventos e que tem a condição de relatá-lo. Neste sentido, a memória desaparece quando a História surge. 
É por isso que, além do processo de interiorização da memória coletiva, uma outra consequência apontada por Nora quanto à historicização da memória é o seu caráter essencialmente alienado. Neste ponto, "ao invés de nos colocar em contínua relação com o passado, ela cria um senso de descontinuidade" (NORA, 1996a: 11). O passado nos é apresentado como o "radicalmente outro", mesmo que, paradoxalmente, essa alienação produza uma reaproximação que reduz os efeitos do distanciamento e garante uma ligação emocional com o passado.

De acordo com Nora (1996a: 14), “nós contrabalanceamos nossa perspectiva alienada tentando ver o passado em plano aberto e em uma hiper-realidade artificial". E, desta forma, "a medida que nossa percepção do passado muda, nós descobrimos razões para olhar novamente para os objetos tradicionais que pareciam não mais guardar nenhum interesse futuro, os lugares comuns, como eram, de nossa identidade nacional".

Neste sentido, os lugares de memória nada mais são do que vestígios de "uma consciência comemorativa que ainda sobrevive em uma História que, tendo renunciado à memória, também a exige" (NORA, 1996a: 6). Ou seja, são rituais de uma sociedade sem rituais e emergem a partir de uma noção de que não existe uma memória espontânea uma vez que, com uma frequência cada vez maior, criam-se arquivos e monumentos, marcam-se aniversários e organizam-se celebrações. Desta forma, um lugar de memória é o resultado da interação mútua e sobredeterminada entre memória e História. Isso porque sem um claro desejo de memória, os lugares de memória perderiam seu sentido e nada mais seriam do que lugares de História. Por outro lado, sem a presença e a intervenção da História, esses lugares não passariam de meros memoriais. Como bem coloca Nora:

Embora seja verdade que o propósito fundamental de um lugar de memória é parar o tempo, impedir o esquecimento, fixar o estado das coisas, imortalizar a morte, e materializar o imaterial (assim como o ouro, dizem, é a memória do dinheiro) - tudo com o objetivo de capturar o máximo de significado possível com a menor quantidade possível de signos - também é claro que os lugares de memória prosperam somente por causa de sua capacidade de mudança, sua habilidade em ressuscitar antigos significados e gerar novos com conexões novas e imprevisíveis (que é o que os torna estimulantes) (NORA, 1996a: 15).

Esta é uma noção que implica um deslocamento radical do olhar do historiador. A partir deste aporte metodológico - que busca as diversas formas em que um mesmo passado foi interpretado ao longo do tempo a partir da maneira com a qual ele se articula à vida cotidiana - as divisões demarcadas por Halbwachs entre a memória e a história perdem muito de sua pertinência. Como bem coloca Dosse (2003), mesmo que esta divisão tenha um valor heurístico importante em um primeiro momento (na medida 
em que separa uma história-memória de uma história-crítica), o dever imperioso da memória rapidamente abre espaço para a reaproximação dos dois pólos: "todas as duas modificadas pela prova da experiência de uma dupla problematização no seio da qual o caráter abstrato, conceitual da história transformou-se a ponto de renunciar à pretensão de tornar-se uma física social cortada do vivido" (DOSSE, 2003: 283). Trata-se mesmo de um deslocamento em direção aos acontecimentos "supersignificados" do passado que marcam as bases narrativas dos discursos fundadores.

Na metáfora de Nora (1996a: 7), os lugares de memória são como conchas deixadas na areia: não estão totalmente vivos, na medida em que a História os molda e fixa, mas também não estão inteiramente mortos quando o mar da memória viva retorna. Isso porque ainda que os antigos símbolos não tenham a capacidade de despertar as mesmas paixões de antigamente, nós ainda nos sentimos extremamente seduzidos por eles. A memória nos chama, ainda que ela não seja inteiramente parte constituinte de nossas vidas. É como se sentíssemos uma ligação visceral com o que nos moldou e nos tornou quem nós somos, ainda que, ao mesmo tempo, não possamos deixar de nos sentir historicamente estranhos a esta herança.

Os lugares de memória são produto de uma sociedade que, por ter pedido seu ancoramento memorialístico nos locais compartilhados da vida social, se torna obcecada por entender os seus próprios processos historicamente. É a isso que pode ser creditado "o papel central do historiador: ele impede que a História seja meramente História" e a transforma em uma estrutura significante. É neste sentido que “o lugar de memória é um espelho distorcido, torcendo os seus próprios temas de modo que defina a sua significância” (NORA, 1996a: 15)

Estes lugares de memória são, portanto, sempre objetos em abismo, o que significa dizer que são "objetos que contém representações de si mesmos (por esta razão, sugerindo um regresso infinito)" (NORA, 1996a: 16). Neste sentido, os lugares de memória são postos, por Nora (1996a: 19), como signos: "ao contrário dos objetos históricos, os lugares de memória não possuem referência na realidade, ou, ao invés disso, eles são suas próprias referências".

Isso posto, podemos delinear com mais precisão como o passado se articula ao presente nas reportagens jornalísticas. O comum representado pelo passado ali posto, dentro de um escopo geral, pode ser visto mesmo como um destes lugares de memória. Isso porque o passado retratado nas matérias remete ao mesmo tempo à articulação de uma visada pretensamente objetiva sobre estes acontecimentos de outrora (visada típica 
da história) ao mesmo tempo em que se articula em torno de um dever lembra-se, de um claro desejo de memória.

E isso porque, conforme já colocamos, o passado se constitui mesmo como um discurso fundador dentro das narrativas jornalísticas, que dá conteúdo e molda os enunciados, funcionando mesmo, como expõe Maingueneau (2008: 38) como um mecanismo que efetua a associação entre "o trabalho de fundação no e pelo discurso" e a "determinação de um lugar associado a um corpo de enunciadores consagrados e uma gestão da memória". Mas, mais do que isso, há um caráter memorialístico fundante nestas narrativas, na medida em que há um claro desejo de memória implicado nos metadiscursos que sustentam a prática jornalística.

É diante deste recurso aos eventos supersignificados do passado que estão ligados mesmo às formas como identitariamente enxergamos o presente, que podemos entender por que a História se posiciona, dentro das narrativas jornalísticas, neste lugar dos discursos que se repetem ou, mais corretamente, que são repetidamente postos como inéditos dentro de um universo de discursos. De forma mais específica, é o que nos permite entender como os lugares de memória, quando estão inseridos nas estórias da imprensa, são mobilizadores de inventários de discursos ligados às práticas representacionais a partir das quais nós fazemos ver o comum, na medida em que eles inscrevem o fato jornalístico em uma rede de significações sociais, reintegrando-o em um conjunto de significados já estabelecidos.

É em torno desta linha de raciocínio que Elias Thomé Saliba (2007) atesta que as mídias estão repletas de imagens-históricas-ônibus (de omnibus, isto é, feitas para todo mundo, extremamente familiares, crivadas de lugares comuns), respaldando uma visão canônica da histórica. Por canônica, o autor se refere "àquelas imagens-padrão ligadas a conceitos-chaves de nossa vida social e intelectual. Tais imagens constituem pontos de referência inconscientes, sendo, portanto, decisivas em seus efeitos subliminares de identificação coletiva. São imagens de tal forma incorporadas em nosso imaginário coletivo, que as identificamos rapidamente" (SALIBA, 2007: 88).

Elas dizem respeito a relances do passado que, de uma maneira geral, não entram em disputa, nem dividem, na medida em que formam um consenso difuso e não polemizam em torno de um entendimento padrão da temática retratada. Para Saliba, é justamente porque estas imagens do passado são familiares o suficiente é que elas são veiculadas, mobilizando, assim, apenas valores já consensualmente postos.

Este imagem consensual que caracteriza os lugares de memória na imprensa também é trabalhada por Carolyn Kitch, quando a autora atesta, após estudar em torno 
de sessenta títulos de revistas informativas norte-americanas, que as narrativas históricas postas ali, embora fossem bastante diferentes entre si, sempre reativavam um mesmo tipo de discurso que dizia respeito aos modos de vida dos norte-americanos e às questões identitárias que uniam a nação. Esse inventário discursivo era mobilizado através de narrativas históricas exemplares (desde o culto a pessoas famosas mortas até retrospectivas dos últimos anos) que resgatavam sempre um mesmo conjunto de valores identificados fortemente com a cultura norte-americana (como a virtude do individualismo, o restabelecimento da ordem a partir da queda do imoral, o triunfo da democracia, entre outros).

Em outras palavras, eram narrativas que fomentavam a formação de um communitas. Tomando como pressuposto o fato de que o passado é capaz de resgatar certas situações de liminaridade que modificam as relações sociais normais, unindo as pessoas a partir da reafirmação dos laços comunais, a mídia, enquanto elemento da cultura, seria capaz de criar tais situações através do enquadramento do passado e da reencenação dessas situações-limite. É como se as narrativas históricas inseridas na imprensa fossem uma das estratégias possíveis que tivessem o poder de ativar discursos criadores de communitas, o que, de uma forma ampla, acaba por realocar o próprio papel do jornalismo. Mais do que um mero mediador de informações, ele se colocaria mesmo como um representante dos interesses compartilhados, em uma espécie de cerimônia que une as pessoas em torno de uma série de valores consensualmente aceitos e ligados à reafirmação dos laços sociais.

Considerando esse processo de inteligibilidade do tempo e da função da história expostos pelos autores citados, podemos entender como o passado funciona, dentro das narrativas jornalísticas, como um mobilizador de inventários de discursos que inscreve o evento particular dentro de um quadro de significações mais gerais. Funciona como uma forma de argumentar em favor de um determinado entendimento a respeito dos eventos do presente tanto a partir deste recurso ao que é comum quanto através da construção de um quadro de prognósticos que tentam delimitar os efeitos ou implicações do que está sendo noticiado.

Até o presente momento, fizemos algumas considerações de ordem geral em torno de autores que trabalham os princípios de semantização envoltos na produção noticiosa e sobre a forma a partir da qual a história contribui com este processo. Neste sentido, pudemos delimitar que as alusões históricas parecem funcionar, dentro das narrativas jornalísticas, como uma estratégia referencial, relacionada mesmo à maneira a 
partir da qual ela se posiciona como a fala legitimada de um outro e como um discurso constituinte. Mais do que isso, no entanto, a história também cumpre um papel de ser um inventariador de discursos em torno do comum, de forma que o fato jornalístico define a sua significação a partir do modo em que ele se insere em um conjunto de significações pré-determinadas e em uma cadeia temporal mais ampla - cadeia esta que, por sua vez, também está sujeita a estes mesmos processos de semantização.

Chega a hora de olharmos estas questões de uma forma mais detida e, através do delineamento metodológico já posto na Introdução, analisar as reportagens que foram coletadas e que constituem o corpus de análise do presente trabalho. Desta forma, no capítulo III, trabalharemos com as funções e sequências narrativas de origem. No capítulo IV, iremos agrupar a análise de duas categorias: as funções e sequências de ordem comparativa (incluindo as quase-lógicas) e as de disjunção. Por fim, no capítulo $\mathrm{V}$, iremos estudar as narrativas de origem. 


\section{CAPÍTULO III}

\section{USOS DA HISTÓRIA E TRAJETÓRIAS PESSOAIS NA REPORTAGEM:}

A MATRIZ DE VERDADE PRESUMIDA E O RECONHECIMENTO DA AÇÃO

A construção das personagens nas narrativas da imprensa é um tema tão caro que não é difícil encontrarmos, em livros sobre a prática, quem defenda que um bom jornalismo depende justamente de uma relação (tanto narrativa quanto interpessoal) mais sofisticada com este interlocutor retratado. Mais do que uma mera apresentação, no entanto, os modos de se contar a vida destas personagens jornalísticas carregam, nas suas construções, uma série de valores e é neste sentido que Kitch (2005: 68) coloca que “as estórias que a mídia conta e que as pessoas 'sabem' a respeito das celebridades são, na verdade, fábulas morais". Neste capítulo, nos ocuparemos da forma como o passado contribui para a semantização do fato jornalístico através dos personagens implicados no relato.

É necessário considerar que o modo de se contar a vida nem sempre foi o mesmo. Conforme coloca Sergio Vilas Boas (2002), até meados do século XVIII, era desconhecida a preocupação em se apontar os aspectos psicológicos envoltos nas decisões tomadas pelos personagens e a maior parte das narrativas se ocupavam de grandes agrupamentos sociais, organizados a partir da hierarquia, das funções ou das profissões dos retratados. Como explica Peter Burke (1997), as biografias anteriores a este período (o termo biographia foi cunhado na Grécia Antiga com o significado mesmo de "escrever vidas") não só ignoravam a cronologia, como também não discutiam o desenvolvimento da personalidade.

Além disso, seus relatos recobriam frequentemente uma série de anedotas irrelevantes como menções a algumas informações de caráter místico (como os sinais no céu no dia do nascimento de determinado personagem ou sinais oraculares) e a profecias. Outra característica era um constante esforço na edificação da imagem do retratado através do recurso às divindades e santos. Usando essas figuras como exemplo, as obras de maior sucesso se concentravam em torno da temática da fé cristã e do fortalecimento da fé vacilante. Além disso, "um santo ou um rei eram obviamente distintos do povo comum, e era dever e prerrogativa do escritor enfatizar tais diferenças" (CLIFFORD apud BOAS, 2002: 34).

Sendo um gênero literário bastante popular durante a época renascentista, as biografias comportavam mesmo certa dissociação entre a realização de um ato e a concepção de sujeito. Isso porque, normalmente, elas apresentavam estórias curiosas 
contadas sobre uma pessoa que, na verdade, já haviam sido atribuídas a várias outras. "A história sobre como o cardeal Granville", por exemplo, "ditava simultaneamente para diversos secretários é o eco de uma anedota que tanto Plínio quanto Plutarco escreveram sobre Júlio César" (BURKE, 1997: 1).

Era justamente uma noção de exemplaridade que ligava os diferentes textos produzidos, deixando entrever aí uma tensão posta entre o indivíduo como exemplar e o indivíduo como único. Não era raro que os retratados fossem representados como a segunda aparição de um outro personagem, do tipo um "segundo Júlio César", por exemplo.

É somente no século XVIII que surge a ideia de que uma biografia deveria comportar as dimensões psicológicas de uma só pessoa e que deveria ter como pano de fundo uma investigação minuciosa e apoiada em uma documentação extensa. E é por isso que, como expõe Contardo Calligaris, que se pode dizer que, apesar do fato de que sempre se escreveram histórias de vida, a ideia de que a vida é uma história é moderna.

Com isso, o autor alude ao fato de que a ideia de uma biografia "implica uma cultura na qual, por exemplo, o indivíduo (seja qual for sua relevância social) situe sua vida ou seu destino acima da comunidade a que ele pertence, na qual ele conceba sua vida não como uma confirmação das regras e dos legados da tradição, mas como uma aventura para ser inventada" (CALLIGARIS, 1998: 46).

É bastante recente, portanto, a ideia de que as biografias possam se constituir como produções que "sugerem o universal embutido na particularidade de um indivíduo" (BOAS, 2002: 37) e que sugiram uma vinculação de coexistência entre a pessoa e o ato.

Para entendermos, portanto, como os dados biográficos trazidos do passado se constituem como articuladores de sentido no jornalismo é necessário remeter ao fato de que diversos estudos insistem exatamente neste ponto, afirmando que uma das características diferenciadoras das biografias mais recentes é justamente esta suposição de que um indivíduo esteja diferenciado de seu grupo, estando, portanto, a relação de coerência não mais no exterior, mas sim, no interior do próprio sujeito. A coerência fundamental de base se desloca, portanto, para uma conexão entre uma personalidade específica e uma ação mais pontual.

Como bem explicam Perelman e Olbrechts-Tyteca (1996), a construção da pessoa humana através da vinculação de coexistência "pessoa-ato" está relacionada a uma distinção entre o que se considera natural ou próprio sobre o ser de quem se fala e o que se considera apenas transitório ou exterior a este sujeito. O estável está relacionado 
aqui a uma concepção particular de "indivíduo", que introduz um elemento de fixidez, assegurado mesmo por um conjunto de técnicas e expressões linguísticas que buscam assegurar uma ideia de permanência - no qual não só os nomes próprios, como também expressões como "ele sempre foi uma pessoa amável" são bons exemplos deste mecanismo ${ }^{30}$.

O transitório está relacionado aos atos que, embora sejam fugazes e momentâneos, podem dizer respeito a algo maior que está posto no indivíduo. É por este mecanismo que um homem corajoso é aquele que realiza ou que realizou atos corajosos ou que, ao menos, conserva a potencialidade de uma ação de bravura.

Desta forma, podemos dizer que, de uma forma geral, "o valor que atribuímos ao ato nos incita a atribuir certo valor à pessoa, mas não se trata de um valor indeterminado". Isso porque "se por acaso um ato acarreta uma transferência de valor, esta é correlativa a um remanejamento de nossa concepção de pessoa, à qual atribuiremos, de um modo explícito ou implícito, cetras tendências, aptidões, instintos ou sentimentos novos" (PERELMAN e OLBRECHTS-TYTECA, 1996: 339).

É, portanto, a partir de uma sobredeterminação complexa entre o valor atribuído ao ato e a apreciação que temos sobre a natureza da pessoa que forma a rede da vinculação de coexistência “pessoa-ato". E é por causa desta ideia de coexistência que, embora o elemento temporal esteja normalmente presente nestas construções, ele adquire, no entanto, um papel secundário.

Neste sentido, Giovanni Levi (1998) chama a atenção para o fato de que poucas vezes a coerência da correlação "pessoa-ato" - ligada a uma ideia de biografia como um elemento sólido e exemplar, de caráter moral - foi questionada. Além disso, as esparsas e pontuais críticas que existiram estiveram normalmente ligadas a momentos de crítica da racionalidade ou de certo embate entre os indivíduos e as instituições ${ }^{31}$.

\footnotetext{
${ }^{30}$ Para Perelman e Olbrechts-Tyteca (1996: 334-335), "todo o argumento sobre a pessoa explicita essa estabilidade: presumimo-la, ao interpretar o ato em função da pessoa, deploramos que essa estabilidade não tenha sido respeitada quando dirigimos a alguém a censura de incoerência ou de mudança injustificada. Grande número de argumentações tende a provar que a pessoa não mudou, que a mudança é aparente, que as circunstâncias é que mudaram, etc.". Não obstante isso, ele enfatizam também que "a estabilidade da pessoa jamais está completamente assegurada; técnicas linguísticas contribuirão para acentuar a impressão de permanência, sendo a mais importante o uso do nome próprio. A designação da pessoa por certos traços (o avarento do seu pai), a hipótese de certos sentimentos (aquela cujo furor perseguiu sua infância), podem igualmente concorrer para isso. A qualificação, o epíteto (esse herói, Carlos Magno da barba florida) visam deixar imutáveis certas características cuja estabilidade fortalece a da personagem. Graças a esta estabilidade é que um mérito adquirido, ou que se vai adquirir, pode ser atribuído a alguém de modo intemporal”.

${ }^{31}$ Um dos momentos desta crítica pontual à coerência biográfica foi posto em questão no século XVIII, segundo Levi (1998: 170) "com o debate que se estabeleceu acerca da possibilidade de escrever a vida de um indivíduo. Partindo do romance (Sterne, Diderot), porquanto este tentava construir a imagem de um homem complexo, contraditório, cujo caráter, opiniões e atitudes estavam em perpétua formação, essa
} 
Desta forma, as informações biográficas sobre um indivíduo adquirem um papel não desprezível nas construções de sentido em um texto que faça o perfil de um personagem, ou que queira avaliar o valor de um determinado evento relacionado a esta pessoa no presente. Perelman e Olbrechts-Tyteca (1996: 341) colocam mesmo que "os atos passados e o efeito por eles produzidos vêm a adquirir uma espécie de consistência, a formar um passivo extremamente nocivo ou um ativo muito apreciável".

Outro exemplo desta relação (ou tensão) entre o permanente e o transitório diz respeito ao tipo de transferência presente entre uma determinada concepção de regularidade da pessoa e da efemeridade de sua fala ou de suas posições. Isto porque o discurso seria a manifestação por excelência da pessoa. E é assim que "o enunciado não é o mesmo quando emana deste ou daquele autor, ele muda de significado; não há simples transferência de valores, mas reinterpretação num contexto novo, fornecido pelo que se sabe do autor presumido" (PERELMAN e OLBRECHTS-TYTECA: 1996: 362).

O que está em jogo nesta relação entre o estável e o transitório pressuposta nas vinculações de coexistência "pessoa-ato" é mesmo certa cumplicidade e conformidade com uma ideia de "ilusão biográfica", se optarmos pela utilização dos termos de Bourdieu. Está em consonância, portanto, com a possibilidade de construção de uma história de vida enquanto um "relato coerente de uma sequência de acontecimentos, com significado e direção" (BOURDIEU, 1996: 185). A "ilusão biográfica" refere-se mesmo a estas narrativas que retratam a vida como um conjunto orientado, que pode ser apreendido a partir da realização de um projeto (que se torna manifesto através de expressões como “desde então", “desde criança”, "sempre gostou”, etc.). E, mais do que isso, há sempre a preocupação de extrair uma lógica dos acontecimentos, de modo que eles possam ser postos em termos de causa e efeito, em um todo coerente.

Os eventos particulares postos pela contingência da vida nada mais são, dentro desta lógica específica, do que momentos ou retratos de algo com um significado maior, expressos mesmo por uma ideia de que a vida pode ser comparada a um trajeto a ser percorrido $^{32}$ Nas palavras do próprio Bourdieu (1996: 183):

crise chega à autobiografia (Rousseau) e finalmente à biografia propriamente dita". Ainda segundo Levi, "tal período apresenta muitas analogias com o nosso: a consciência de uma dissociação entre o personagem social e a percepção de si adquire aí particular intensidade. Os limites da biografia estão claramente percebidos, ao mesmo tempo em que assistem ao triunfo do gênero biográfico" (LEVI, 1998: 170).

${ }^{32}$ Nas palavras do próprio Bourdieu (1996: 183), "falar de história de vida é pelo menos pressupor - e isso não é pouco - que a vida é urna história e que, como no título de Maupassant, Urna vida, uma vida é inseparavelmente o conjunto dos acontecimentos de urna existência individual concebida como urna história e o relato dessa história. É exatamente o que diz o senso comum, isto é, a linguagem simples, que descreve a vida como um caminho, uma estrada, urna carreira, com suas encruzilhadas (Hércules entre o vício e a virtude), seus ardis, até mesmo suas emboscadas (Jules Romains fala das sucessivas emboscadas 
falar de história de vida é pelo menos pressupor - e isso não é pouco - que a vida é urna história e que, como no título de Maupassant, Urna vida, uma vida é inseparavelmente o conjunto dos acontecimentos de urna existência individual concebida como urna história e o relato dessa história. É exatamente o que diz o senso comum, isto é, a linguagem simples, que descreve a vida como um caminho, uma estrada, urna carreira, com suas encruzilhadas (Hércules entre o vício e a virtude), seus ardis, até mesmo suas emboscadas (Jules Romains fala das sucessivas emboscadas "dos concursos e dos exames"), ou como um encaminhamento, (...) um trajeto, uma corrida, um cursus, uma passagem, uma viagem, (...), um deslocamento linear, unidirecional.

No presente capítulo, nos ocuparemos em delimitar como se estrutura esse jogo entre o estável e o transitório nas "funções narrativas de trajetórias pessoais" presentes nas reportagens do corpus analisado. De uma maneira geral, elas se dividem em três grandes grupos de análise, a saber, um que pressupõe a vinculação de coexistência "pessoa-ato" no que concerne à função testemunhal jornalística (BT), um que coloca essa relação dentro de um jogo de "coerências pressupostas" entre as ações do presente e os atos do passado (BA) e, por fim, um na qual a biografia do indivíduo serve apenas como ilustração para uma problemática maior, ou seja, uma biografia modal (BM).

A divisão entre essas três categorias nas reportagens presentes no corpus obedecem à seguinte proporção ${ }^{33}$ :

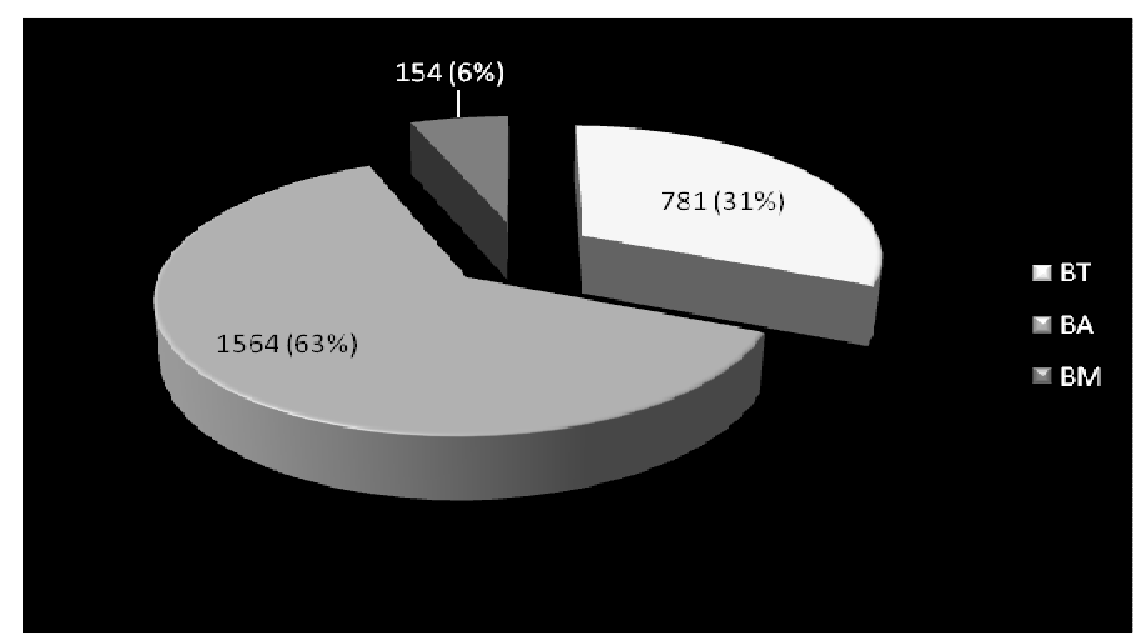

"dos concursos e dos exames"), ou como um encaminhamento, isto é, um caminho que percorremos e que deve ser percorrido, um trajeto, uma corrida, um cursus, uma passagem, uma viagem, um percurso orientado, um deslocamento linear, unidirecional (a "mobilidade"), que tem um começo ("uma estreia na vida"), etapas e um fim, no duplo sentido, de término e de finalidade ("ele fará seu caminho" significa ele terá êxito, fará uma bela carreira), um fim da história".

${ }^{33}$ A soma do número das funções e sequências de trajetórias pessoais apontada aqui é maior do que o número posto anteriormente porque em uma mesma matéria pode haver dois ou mais trechos biográficos que pertencem a categorias diferentes. Adotamos, neste sentido, o mesmo procedimento adotado anteriormente: as categorias foram contabilizadas de acordo com sua aparição nas matérias e mesmo que ela estivesse presente em dois trechos diferentes, ela foi contabilizada apenas uma vez. 
Pelo gráfico, podemos perceber que, somadas as ocorrências das funções e sequências narrativas nas três revistas pesquisadas, há uma maior quantidade daquelas que estão ligadas ao julgamento da ação (com ocorrência de 63\%). Ela é seguida por aquelas que concernem à função testemunhal jornalística (com 31\%) e pelas biografias modais $(6 \%)$.

Esta predominância é mantida mesmo quando analisamos os veículos individualmente e a divisão destas categorias nas quatro revistas analisadas é a seguinte:

\begin{tabular}{|cccccccccc} 
& \multicolumn{2}{c}{ Veja } & \multicolumn{2}{c}{ Época } & \multicolumn{2}{c}{ IstoÉ } & \multicolumn{2}{c}{ Carta Capital } \\
& Total & $\%$ & Total & $\%$ & Total & $\%$ & Total & $\%$ \\
BT & 163 & $30,01 \%$ & 235 & $32,72 \%$ & 179 & $28,73 \%$ & 204 & $30,72 \%$ \\
BA & 333 & $61,32 \%$ & 420 & $58,49 \%$ & 373 & $59,87 \%$ & 438 & $65,96 \%$ \\
BM & 47 & $8,65 \%$ & 63 & $8,77 \%$ & 71 & $11,39 \%$ & 22 & $3,31 \%$ \\
\hline
\end{tabular}

Com bem pontua Paula Backscheider (2002: 3), “a pessoa mais invisível em uma biografia, é também a mais poderosa: o autor. A todo o momento sua voz pode ser ouvida - mas não é. (...) Quando nós não notamos [a voz do biógrafo], nós corremos o risco de esquecer o quanto a biografia é mais a interpretação do que o fato e por que isso importa tanto". A forma como o jornalista trabalha com estas histórias de vida é, neste sentido, fundamental para compreendermos como se dá a utilização dos dados históricos na construção das reportagens.

\section{O Estatuto do Testemunho no Jornalismo: a matriz de verdade presumida}

Sem testemunhas, não há jornalismo. Muito embora estejamos usando aqui uma noção bastante ampla de "testemunha" - que pode ser entendida tanto como alguém que presenciou um evento marcante quanto como um especialista ou estudioso que se debruça sobre a temática proposta ${ }^{34}$ - o que queremos dizer por isso é que não há jornalismo que não se apoie sempre na fala de um outro. E isso ao ponto de alguns autores afirmarem que "a notícia não é algo que acontece, mas algo que alguém diz que acontece" (SIGAL apud HUXFORD, 2004: 19). Este crédito dado ao testemunho é, portanto, uma das fases cruciais e mais complicadas do trabalho jornalístico, uma vez que diz respeito mesmo à sua matriz de verdade presumida.

\footnotetext{
${ }^{34}$ O uso do termo "testemunho" tanto para sentenças que guardam a especificidade do "eu vi" quanto a do "eu sei" será justificada posteriormente.
} 
Esta construção de um lugar de verdade pressuposta implicada no testemunho jornalístico - seja em relação ao testemunho ocular do próprio jornalista, seja a partir do recurso às aspas de terceiros, especializados ou não - se deixa entrever nas próprias falas dos profissionais de imprensa. Não é por acaso que Cláudio Abramo (1988: 110) coloca que "o jornalista deve ser aquele que conta a terceiros, de maneira inteligível, o que acabou de ver e ouvir".

Também Ricardo Kotscho (apud CRIPPA, 1998: 16) retoma essa ideia quando define a entrevista como "uma arte da conquista", uma vez que "o entrevistado tem que ser conquistado para dizer aquilo que você quer saber". Uma vez que o objetivo do entrevistador é "tentar extrair a verdade" do entrevistado, também Armando Nogueira a define em termos muito parecidos, como "um verdadeiro duelo que você trava com o entrevistado" (NOGUEIRA apud CRIPPA, 1998: 92). O elemento comum presente nas três falas é justamente a pretensão da extração de um verdadeiro do testemunho.

No Manual de Redação do jornal O Estado de São Paulo está posto que "a entrevista constitui uma das principais fontes de informação de um jornal e está presente, direta ou veladamente, na maioria das notícias que ele publica. Ela pode tanto ser a própria reportagem como apenas parte dela" (MARTINS, 2003).

A partir do reconhecimento da importância do testemunhal no jornalismo, Nilson Lage (2008: 21) coloca que "se os séculos XVII e XVIII foram os do jornalismo publicista e o século XIX o do jornalismo educador, o século XX foi o do jornalismotestemunho". É justamente a esse recurso constante de apoio na fala do outro que Lage se refere e que confere a ele um estatuto privilegiado dentro da imprensa noticiosa.

As relações entre o testemunhal e o jornalismo são variadas e complexas, estando sujeitas mesmo às variações de percepção sobre qual deve ser o papel social da imprensa. Como coloca Mouillaud (2002: 117): "a relação entre a fala do jornal e as outras falas modificou-se com a mudança do lugar e da função da imprensa", modificando mesmo a forma como as informações são articuladas e como se estrutura a ideia de "verdade" subjacente ao exercício da prática.

Isso porque é justamente o testemunho uma das etapas que alicerçam as pretensões do verdadeiro e que buscam garantir uma objetividade de base. Se voltarmos à noção de Ricoeur de que a pretensão de fidelidade com os fatos é engendrada tal como um voto, a fase testemunhal do jornalismo é um dos mecanismos que tentam garantir imaginariamente o seu cumprimento.

$\mathrm{O}$ ato de testemunhar, dentro de uma concepção geral, guarda a especificidade de ser uma ação que não pode ser dada a partir da separação ente a asserção da realidade 
e a autonomeação do sujeito que testemunha. Assim, ela conserva em si duas vertentes que estão inicialmente separadas, mas que se articulam uma sobre a outra, que são: "de um lado, a asserção da realidade factual do acontecimento relatado; de outro, a certificação ou a autentificação da declaração pela experiência de seu autor, o que chamamos de sua confiabilidade presumida" (RICOEUR, 2007: 172).

É a partir deste acoplamento inicial que, para Ricoeur (2007), o testemunho seria o resultado da articulação de três momentos que podem ser expressos pelas máximas: "eu estive lá", "acreditem em mim"; "e se não acreditarem em mim, perguntem a outra pessoa".

Quanto ao primeiro termo, ele se refere ao fato de que é a testemunha que se declara testemunha, ou seja, ela nomeia a si mesma ${ }^{35}$. Esta autodesginação tem um duplo efeito: ela "liga o testemunho pontual a toda a história de uma vida", ao mesmo tempo em que "faz aflorar a opacidade inextricável de uma história pessoal que foi ela própria “enredada em histórias"” (RICOEUR, 2007: 173).

Como é sempre diante de alguém que o testemunho se processa, instaurando, assim, uma situação dialogal, a segunda fase diz respeito a este aparecimento de um momento fiduciário e de um pedido de crédito na palavra. É este credenciamento que traz a escolha entre a confiança e a suspeita e é a resposta a isso que autentifica o testemunho. Uma vez acreditado, abre-se o espaço para a terceira etapa, ou seja, para a crítica ao testemunho que se dá a partir do confronto deste com outras narrações circunstanciadas, como forma de reforçar a credibilidade do narrado.

Ao aproximar as fronteiras entre a ocorrência do fato e a presença do narrador que se coloca para poder ser problematizada ou referendada posteriormente, instalada em uma situação dialogal -, Ricoeur coloca o testemunho como uma espécie de instituição social, como um fator de amparo no conjunto das relações que asseguram os vínculos societários. Isso porque, segundo o autor, é mesmo a confiabilidade de cada testemunho que assevera a segurança do vínculo social na medida em que ele repousa na confiança na palavra de outrem.

"O que a confiança na palavra de outrem reforça, não é somente a interdependência, mas a similitude em humanidade dos membros da comunidade. $\mathrm{O}$ intercâmbio das confianças especifica o vínculo entre seres semelhantes”. Em resumo, "é da confiabilidade, e, portanto, da atestação biográfica de cada testemunha

\footnotetext{
${ }^{35}$ Ricoeur chama a atenção para o triplo dêitico que pontua essa autodesignação: "a primeira pessoa do singular, o tempo passado do verbo e a menção ao lá em relação ao aqui". Além disso, "esse caráter autoreferencial é por vezes sublinhado por certos enunciados introdutórios que servem de "prefácio"" (RICOEUR, 2007: 173).
} 
considerada uma a uma que depende, em última instância, o nível médio de segurança de linguagem de uma sociedade" (RICOEUR, 2007: 175).

Ricoeur se refere aqui ao fato de que o ato de testemunhar tem consistência e sentido apenas porque supomos que uma pessoa é capaz de dizer a verdade, ou seja, porque se confia na capacidade cognitiva do outro, mas, mais do que isso, porque se acredita no comprometimento moral deste que fala ${ }^{36}$. É neste aspecto está o caráter moral do testemunho e o seu estatuto como um laço de sociabilidade.

É, portanto, na pressuposição de um mundo comum que está instalada a crítica e a confiabilidade no testemunho.

Esta pretensão de verdade que ele guarda está no próprio cerne da palavra. Sua raiz está ligada, em latim, a duas expressões: "testis" e "superstes" 37 , sendo que a primeira diz respeito à ideia de "um depoimento de um terceiro em um processo". Seligmann-Silva (2003: 277-278), aponta no quinto livro de Moisés uma passagem clássica para exemplificar esse sentido de "testemunho" como um "terceiro" ligado a demandas de justiça: "uma só testemunha contra ninguém se levantará por qualquer iniquidade ou por qualquer pecado, seja qual for o pecado que pecasse; pela boca de duas testemunhas, ou pela boca de três testemunhas, se decidirá a contenda".

Este "terceiro" presente na própria palavra já aponta, portanto, para a temática da investigação da verdade e, "traz a luz o fato de que o testemunho por definição só existe na área enfeitiçada pela dúvida e pela possibilidade de mentira" (SELIGMANNSILVA, 2003: 278).

É a partir desta colocação do testemunho como uma "instituição social” e da sua ligação com o verdadeiro que Derrida o define como "uma promessa de verdade até mesmo no perjúrio" (DERRIDA, 1997: 89). Isso porque, para ele, há mesmo uma fiabilidade que funda toda a relação com o outro no testemunho. Como não há resposta sem um princípio de responsabilidade - ou seja, "é preciso responder ao outro, diante do outro e de si próprio" -, esta não pode ser concebida fora de um campo que envolva uma fé jurada ou um juramento, nos termos sempre de uma ação ou, em outras palavras, de um "eu comprometo-me a tanto diante do outro a partir do momento em que me dirijo a ele, ainda que só e talvez, sobretudo, se para cometer perjúrio”.

\footnotetext{
${ }^{36}$ Sobre isso, ver KOLLERITZ, 2004.

${ }^{37} \mathrm{O}$ sentido de superstes está ligado à ideia de "sobrevivente" e indica a pessoa que passou por uma grande provação. "O conceito de mártir está próximo a essa acepção de sobrevivente. Martyros em grego significa justamente testemunha. (...) a acepção do testemunho como sobrevivente e como mártir indica a categoria excepcional do 'real' que o testemunho tenta dar conta a posteriori" (SELIGMANN-SILVA, 2003: 278).
} 
É justamente a possibilidade de manutenção desta promessa de verdade mesmo na mentira - que assegura o vínculo e laço social ${ }^{38}$. Qualquer endereçamento ao outro se tornaria impossível sem a manutenção desta concepção. E é por isso que "no testemunho, a verdade é prometida para além de toda a prova, toda a percepção, toda a mostração intuitiva". E assim, "ainda que eu minta ou perjure (e sempre e, sobretudo, quando o faço), prometo a verdade e peço ao outro para crer no outro que sou, aí onde sou eu o único a poder testemunhar e onde nunca a ordem da ordem ou da intuição serão redutíveis ou homogêneas a essa fiduciariedade elementar, essa 'boa fé' prometida ou requerida" (DERRIDA, 1997: 89).

Como está implicada em toda a ligação social, a problemática do testemunho está no cerne tanto da religião ${ }^{39}$ quanto da ciência ou da filosofia ${ }^{40}$. Neste sentido, o "eu vi" concebido originalmente como característica do testemunhal pode ser articulado também na forma de um "eu sei". Neste sentido, "religião e razão desenvolvem-se conjuntamente, a partir deste recurso comum: o penhor testemunhal de todo e qualquer performativo, que nos compromete a responder tanto diante do outro como pela performatividade performante da tecnociência" (DERRIDA, 1997: 44).

São estas condições expostas por Derrida e Ricoeur que permitem pensar o testemunho como uma das matrizes da verdade presumida do jornalismo, mesmo que esta consequência lógica da entrevista esteja fundada, como coloca Morin (1973: 120), "na mais duvidosa e mais rica das fontes, a palavra" e, assim, sob "o risco permanente da dissimulação ou da fabulação".

A crítica e a confiabilidade na palavra do outro é mesmo uma prática comum no trabalho jornalístico e isso está diretamente relacionado ao fato, como coloca Sigal (apud HUXFORD, 2004: 19), de que “os repórteres raramente estão na posição de testemunhar um evento em primeira mão. Eles têm que confiar na percepção de outros".

\footnotetext{
38 “Sem a experiência de performativa deste ato de fé elementar, não haveria nem 'laço social', nem endereçamento ao outro, nem qualquer performatividade em geral: nem convenção, nem instituição, nem constituição, nem estado soberano, nem lei, nem, sobretudo, aqui, essa performatividade estrutural da performação produtiva que liga desde o início o saber da comunidade científica ao fazer, a ciência à técnica" (DERRIDA, 1997: 64).

${ }^{39}$ No caso da religião, Derrida coloca que Deus ocupa o lugar da testemunha absoluta, sem o qual não pode haver testemunho absoluto. "Mas com Deus, um Deus presente, a existência de um terceiro (terstis, testis) absoluto, toda a atestação se torna insignificante e secundária” (DERRIDA, 1997: 43). Além disso, não haveria a possibilidade de existência da religio sem uma promessa de testemunho em verdade da verdade. "Não há religião sem promessa de manutenção da promessa de dizer a verdade - de a já ter dito! - no próprio ato da promessa" (DERRIDA, 1997: 46).

40 "As luzes da crítica e da razão teletecnocientífica não podem deixar de supor a fiabilidade. Têm de aplicar uma 'fé' irredutível, a de um 'laço social' ou de uma 'fé juramentada', de um testemunho ('prometo-te a verdade para além de toda a prova e de toda a demonstração teórica, acredita em mim, etc.), quer dizer de um performativo de promessa em ação até mesmo na mentira ou no perjúrio e sem o qual nenhum endereçamento ao outro seria possível" (DERRIDA, 1997: 64).
} 
Além disso, "alguns desenvolvimentos - tendências socioeconômicas, mudanças na opinião pública, alteração do pensamento oficial - não se manifestam por si só nos eventos", e mesmo quando os repórteres estão em condições de falar diretamente sobre algum caso, há todo um conjunto de convenções profissionais que os levam a procurar o testemunho do outro.

Não é por acaso que a revista Veja coloca, no editorial da edição de 18/02/2009, que "é enorme o peso que tem em um processo judicial o depoimento de uma testemunha ocular. Este tipo de relato, quando dado de boa-fé e sem inconsistências é decisivo na formação do veredicto. Na política, os testemunhos de personagens com intimidade com os fatos que revelam são igualmente poderosos". Ela utiliza este mote como forma de introduzir a entrevista que Jarbas Vasconcelos havia concedido à publicação, definindo-o como "um depoimento que não se pode ignorar", afinal relataria, "com a eloquência das testemunhas oculares", uma série de denúncias contra seu partido. Mais do que isso, "o Brasil precisa acompanhar muito de perto o desenrolar do depoimento do Senador a VEJA. Ele tem tudo para ser o motor de um profundo e histórico processo de limpeza da vida pública brasileira"41 (VEJA, 18/02/2009: 12-13).

Os dados históricos presentes nas reportagens muitas vezes estão ligados a este momento testemunhal na imprensa. Mais precisamente, vinculados à segunda etapa exposta por Ricoeur, dentro do que poderíamos chamar de "fase de crítica" ou "fase fiduciária" do testemunho, ou seja, quando se realiza o julgamento crítico da entrevista exposta e um pedido de crédito ou de desconsideração da palavra. Eles dizem respeito, portanto, a este momento que, nas palavras de Veja, conferem "boa fé" e "consistência" para a formação de um veredicto.

A mobilização de determinadas informações do passado do retratado (em detrimento de outras) serve mesmo como um importante articulador de sentidos, na medida em que vinculam diferentes pressupostos e subentendidos nos enunciados propostos. Podemos pensar em muitos exemplos que mobilizam esse mecanismo.

O caso do pedido de asilo político de Cesare Battisti para o Brasil é interessante de ser analisado, neste sentido, porque além de ter atraído uma grande atenção na mídia no ano de 2009, ele possui uma particularidade: as narrativas da imprensa foram

\footnotetext{
${ }^{41}$ Esta possibilidade de limpeza na vida pública brasileira é explicada por Veja quando, neste mesmo texto, ela compara o depoimento de Vasconcelos com os acontecimentos anteriores ao impeachment de Fernando Collor. Segundo o editorial, "o processo que culminou com o impeachment do presidente da República Fernando Collor, em 1992, começou com um desses depoimentos, a espantosa entrevista que seu irmão concedeu a VEJA em maio daquele ano e que foi estampada na capa com a chamada 'Pedro Collor conta tudo'. A Carta ao Leitor daquela edição tinha o título 'Depoimento que não se pode ignorar'. Não foi. Dezenove semanas depois das revelações do irmão a VEJA, Collor deixava a presidência" (VEJA, 18/02/2009: 12).
} 
construídas usando-se como recurso principal o confronto dos diversos testemunhos dos personagens envolvidos - que eram ora acreditados, ora desmerecidos, em função do posicionamento do veículo em questão.

As quatro revistas semanais analisadas publicaram reportagens a respeito deste assunto e, muito embora as fontes consultadas fossem bastante variadas, os expedientes utilizados para acreditar ou desacreditar seus depoimentos não foram essencialmente diferentes. Eles estavam calcados, prioritariamente, em fragmentos biográficos dos testemunhantes. E assim, através da análise destas reportagens, podemos entrever as três variações principais no que diz respeito às possibilidades de usos da história para acreditar ou desmerecer um testemunho, a saber: (1) uma informação biográfica antiga que qualifica a fala a priori; (2) uma informação biográfica antiga que indica uma vivência direta do ocorrido e (3) uma informação biográfica antiga que indica um saber ou uma autoridade de fala sobre o assunto. É o que mostraremos a seguir.

Em 12 de Janeiro, a revista Época publicou uma reportagem que continha a opinião de diversas personalidades acerca do caso. Ao lado de um quadro que continha a fala de várias delas e no qual Fernando Gabeira, consultado, respondia "é uma injustiça. Nos livros ele afirma que não cometeu os crimes", a reportagem acrescenta a seguinte informação: "integrante da equipe de guerrilheiros que sequestrou o embaixador Charles Elbrick, o deputado Fernando Gabeira é um aliado de Battisti - e já declarou que acredita em sua inocência” (LEITÃO e RAMOS, 12/01/2009: 38).

Além desta, há no texto, ainda outra menção à ditadura militar brasileira ligada a uma informação biográfica, no lead da reportagem:

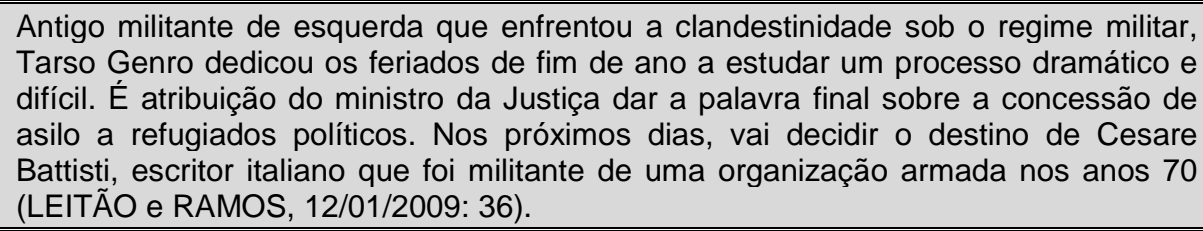
Tarso Genro dedicou os feriados de fim de ano a estudar um processo dramático e difícil. É atribuição do ministro da Justiça dar a palavra final sobre a concessão de asilo a refugiados políticos. Nos próximos dias, vai decidir o destino de Cesare Battisti, escritor italiano que foi militante de uma organização armada nos anos 70 (LEITÃO e RAMOS, 12/01/2009: 36).

Também a revista Veja faz menções deste tipo, porém, suas reportagens sobre o tema chamam a atenção pelas mudanças que se podem notar entre uma e outra edição. A publicação dedica, neste mês, duas reportagens a este tema, uma em 21 de Janeiro e outra na edição seguinte, de 28 de Janeiro. O posicionamento da revista, no entanto, muda radicalmente de uma semana para outra. Se na primeira, o editorial colocava que "Tarso pode estar certo", a outra afirmava categoricamente, na capa, ao lado de uma foto de Battisti, que "vimos os processos do italiano: é terrorista mesmo". 
Na primeira edição, o editorial avaliava a decisão de Genro nos seguintes termos: "sendo Tarso Genro quem é, um político de esquerda, militante socialista e com longa folha corrida de decisões tisnadas por suas convicções ideológicas, nada mais natural do que concluir que essas mesmas forças o levaram a conceder o benefício a Battisti” (VEJA, 21/01/2009: 10). Apesar de condenar este fato e o reiterar na matéria correspondente, a revista coloca que "neste caso, no entanto, a hipótese de que Tarso Genro tenha tomado uma decisão correta não pode ser descartada sem um exame minucioso" (VEJA, 21/01/2009: 73).

Embora os personagens consultados, bem como o conteúdo de suas falas, sejam diferenciados entre si, o elemento comum presente nestas reportagens é justamente a maneira como o passado qualifica o testemunho apresentado, de sorte que ele funciona como uma forma de autenticação do relato. Trata-se de um mecanismo posto em ação tanto por Veja quanto por Época quando justificam a decisão de Genro baseadas em momentos de sua biografia quanto, no caso da segunda, quando evoca as experiências políticas anteriores de Fernando Gabeira. Neste sentido, os elementos biográficos reposicionam o lugar de fala de onde partem os entrevistados. Ele delimita o modo de aparição deste personagem dentro da narrativa, bem como o modo como ele é posto relacionalmente com os outros.

Através de marcadores de pressuposição - como "sendo quem é", no caso da primeira; "já declarou”, na segunda e; por fim, o paralelismo posto por Época entre o passado de Genro e a decisão do futuro de Battisti (ambos “militantes”) -, circunscrevese uma relação de continuidade entre as experiências passadas e os atos mais imediatos do presente (a concessão do refúgio, no caso de Genro; e a fala favorável à Battisti, quanto a Gabeira). Essas expressões efetuam a ligação entre um passado evocado e um presente posto, de forma que eles são articulados a partir de uma relação de contiguidade $^{42}$. Eles dizem respeito à construção de um campo de entendimento comum a partir do qual o passado biográfico se torna similar ao presente.

Estes marcadores de pressuposição demarcam, de forma clara, aquilo que Perelman e Olbrechts-Tyteca (1996) se referiam como a vinculação de coexistência "pessoa-ato". Os termos marcam a passagem, em outras palavras, entre algo considerado fixo (os comportamento do passado remetendo a uma fixidez da

\footnotetext{
${ }^{42}$ Podemos notar, ainda, que o marcador de pressuposição "já" assume na formulação um caráter ambíguo: pode significar tanto "neste momento" ou "agora" (pressupondo apenas que a fala teria acabado de ser dita) como pode remeter à expressão "sem demora" (bem menos neutra que a anterior, deixando entrever mesmo uma relação forte de contiguidade entre o presente e o passado).
} 
identidade) e o que é fugaz e transitório (as decisões implicadas no presente), pressupondo que os dois momentos devem ser postos lado a lado, em contato.

Marcada a interação, os subtendidos estão ligados, nestes casos, à conjeturação do mundo comum que, como já havíamos explicitado, é necessário para a instalação da crítica e da confiabilidade do testemunho.

Isto diz respeito, nos dois casos, à geração de um conjunto de expectativas relacionadas a cada fala para o julgamento do posicionamento dos entrevistados. Uma vez que determinada postura se torna esperada, gera-se a impressão de que a fala não poderia ter sido outra. As questões levantadas pelo depoente para seu posicionamento não são sequer discutidas. A biografia ganha uma força metonímica de explicação e se torna o articulador principal de sentidos. Deste modo, os demais argumentos apresentados pelos entrevistados adquirem um caráter secundário. É como se todas as questões levantadas por Genro ou Gabeira servirem como meras muletas para algo que já estaria dado a priori: é a própria biografia que se torna o principal eixo explicativo de suas condutas e não uma análise dos argumentos internos à própria fala.

Este é um recurso comumente utilizado em matérias jornalísticas e fica bastante claro na coluna de Leonardo Attuch, da revista IstoÉ, publicada em 11/03/2009. Ao comentar uma declaração de Tarso Genro - de que o Movimento dos Trabalhadores Sem Terra (MST) usava táticas arrojadas, sem "nenhuma palavra de condenação, luto ou mesmo de solidariedade em relação às vítimas" - o comentarista político argumenta:

Consta que na juventude Tarso Genro foi um radical militante comunista, adepto da
revolução bolchevique. Com o passar dos anos, teria vindo a maturidade e, com ela,
algum equilíbrio e uma certa sabedoria. Na família, o gene maluquiinho continuaria
se manifestando apenas na filha Luciana Genro, deputada federal pelo PSOL. Mas
quem sai aos seus não degenera, já dizia o provérbio. A filha é o espelho do pai. Ou
quiçá, o pai é o espelho da filha (ATTUCH, 11/03/2009: 38).

Os argumentos de Genro para seu posicionamento (que foram, aliás, expostos por ele na entrevista a qual Attuch se refere) não são sequer citados ${ }^{43}$. Partes de sua biografia e as pressuposições da influência destes fragmentos do passado nos atos do

\footnotetext{
${ }^{43} \mathrm{Na}$ entrevista citada por Attuch, Genro explicava minuciosamente as razões de seus posicionamentos e afirmava que: "Não vejo nenhum índice de aumento de violência [na atuação do MST]. O que ocorre é a mobilização dos movimentos sociais e em determinadas circunstâncias de maneira mais arrojada. Quando eles violam a lei e a Constituição os estados têm que operar. (...) A questão de ocupação da propriedade privada, segundo a Constituição e a lei, é uma questão de ordem pública dos estados. Eles é que tem que preservar isso. Se tiver algum tipo de pedido, o ministério examina e nunca faltou a nenhum estado o apoio do Ministério da Justiça quando se solicita a ajuda da Força Nacional de Segurança. Ou, eventualmente, e daí é responsabilidade da Polícia Federal, quando há ocupação de um prédio público da União. Aí a Polícia Federal tem feito desocupações de forma tranquila e natural". (G1 NOTÍCIAS, 02/03/2009).
} 
presente são apresentadas como parâmetros suficientemente explicativos para o julgamento de seu testemunho.

Podemos comparar estes aspectos com outras reportagens publicadas sobre o caso Battisti. De todas as revistas, a Carta Capital foi a única que desde a primeira matéria publicada se colocou como explicitamente contrária à concessão do refúgio. Além de um editorial de Mino Carta que já deixa explícita a posição da revista ${ }^{44}$, a reportagem sobre o caso já começa com a seguinte afirmação demeritória: "O foragido italiano Cesare Battisti sabia o que fazia quando escolheu como país de destino o Brasil, terra pródiga em abrigar malfeitores internacionais”. Embora utilize diversos fatos para qualificar as opiniões de seus entrevistados, a fala que atende às condições de nosso corpus está em um trecho que apela para a emoção dos leitores, quando entrevista uma das supostas vítimas de Battisti é entrevistada:

O filho de Torregiani, Alberto, atingido por um dos disparos, acabou paraplégico aos
15 anos de idade. Ele e Adriano Sabbadin, filho de Lino, foram os primeiros a
protestar na Itália contra a decisão de Tarso Genro de considerar Battisti refugiado
político. 'O fato de Battisti estar ou não na prisão não me restitui meu pai. Mas não
pode haver paz sem justiça, e minha família ainda não teve justiça. Não tenho
palavra para exprimir a raiva e a indignação', declarou Sabbadin (MENEZES,
21/01/2009: 36 ).

Trata-se de uma construção similar a que a revista Veja coloca, já na sua fase contrária à decisão de Genro ${ }^{45}$, ao trazer a seguinte informação: "Maria Cecília B, exnamorada do terrorista, relatou às autoridades italianas: 'Na primavera de 1979, Battisti, ao descrever-me a experiência de matar uma pessoa, fez referência ao homicídio de Santoro (o agente penitenciário Antonio Santoro), indicando a si mesmo como um dos autores" (DINIZ, 28/01/2009: 55).

Embora construídas a partir de personagens e de falas diferentes, também as funções narrativas de trajetórias pessoais evocadas na Carta Capital e na segunda reportagem da Veja obedecem ao mesmo mecanismo que fizemos alusão anteriormente:

\footnotetext{
${ }^{44}$ No editorial intitulado "Afrontado o Estado italiano", Carta coloca que "o ministro da Justiça, Tarso Genro, ao conceder asilo político a Cesare Battisti, entende que a Itália é um país sem lei e sem justiça, ali não vigora o Estado de Direito. Os fatos indicam outra situação, inclusive que a Constituição italiana de 1948 é uma das mais resistentes do mundo". Depois de questionar todos os motivos alegados por Genro, Carta finaliza o editorial afirmando que "por mais que nos esforcemos [em entender os motivos], só conseguimos enxergar os resistentes de uma esquerda saudosista e obsoleta a trafegar entre a festa e o corporativismo" (CARTA, 21/01/2009: 16).

${ }^{45}$ Nesta reportagem, Veja coloca que: "Na Carta ao Leitor de sua última edição, VEJA deu crédito a Tarso Genro, ministro da Justiça que, depois de 'estudo cuidadoso' dos processos italianos, disse não ter encontrado neles provas concretas que colocassem Cesare Battisti na cena dos quatro homicídios pelos quais havia sido condenado à prisão perpétua em seu país. (...) A reportagem de VEJA refez na semana passada o mesmo estudo que Tarso Genro garantiu ter feito (...). Os resultados obtidos desmentem em sua essência todos os argumentos do ministro da Justiça brasileiro. Havia a possibilidade de Tarso estar certo, mas agora há a certeza de que ele está errado" (DINIZ, 28/01/2009: 54).
} 
o testemunho do filho do homem supostamente assassinado por Battisti ou de sua exnamorada são referendadas, justamente, pelas informações biográficas que são levantadas.

Aqui há, no entanto, uma diferença em relação às anteriores. É pela vivência direta que se cria a impressão de que as testemunhas estão autorizadas a comentar sobre o assunto e, mais do que isso, tem o seu depoimento acreditado. A presunção de verdade é acionada pela posição que os personagens assumiram na cadeia de eventos passados e, como participantes diretos dos acontecimentos, suas falas funcionam como provas de autenticidade das posições que se querem confirmadas.

Como comenta Charaudeau (2006: 215-216), as entrevistas que envolvem esta observação imediata de algo pelo entrevistado não raro envolvem a exploração dos elementos emocionais envolvidos na estória e, neste sentido, "a entrevista do testemunho é um gênero que se presume confirmar a existência de fatos e despertar a emoção, trazendo uma prova de autenticidade pelo "visto-ouvido-declarado"”.

Em todos os exemplos citados, o pedido de ancoramento da verdade está justamente na ligação do testemunho pontual (ligado ao instante da entrevista) com um determinado passado ligado a uma história de vida. Mas, se nos dois primeiros, essa biografia estava posta a partir de uma relação comparativa que colocava a biografia como um elemento explicativo da fala que é dado a priori (e que a justifica antes mesmo de ser proferida); são nestes últimos que o testemunho biográfico aparece em sua formulação mais clássica, reafirmando mesmo o "eu estava lá", engendrando os personagens como atores e/ou vítimas.

Estamos diante, portanto, de duas formas bem distintas de autenticação do testemunho a partir de dados biográficos antigos. Podemos delinear, ainda, um outro modelo de abordagem.

Na revista Carta Capital, de 04/02/2009, a coluna de Wálter Fanganiello Maierovitch tinha como temática a desarticulação dos argumentos apresentados por Genro no caso Battisti e a defesa de que o ex-terrorista deveria buscar a revisão crítica de seu julgamento na Itália, de onde partiu a condenação. Para atestar a legitimidade dos pareceres que seriam emitidos, o colunista faz referência à atuação dos magistrados nos chamados anos de chumbo na Itália, citando o juiz Giancarlo Caselli, conhecido como um toghe rosse ("toga vermelha"), ou seja, marcado por sua vinculação a uma posição política de esquerda. A atestação da genuinidade e retidão do testemunho que poderia ser dado pelo juiz que, segundo Berlusconi, seria o de toga mais vermelha, é posto da seguinte forma: 
Caselli foi o juiz, ao tempo de Battisti, que esteve na linha de frente nas apurações sobre terrorismo, nos chamados 'anos de chumbo' quando, pelas armas e não pelo voto, tentava-se derrubar o Estado democrático italiano, com um presidente socialista, que combatera o fascismo. O presidente socialista da época de Battisti no PAC, convém lembrar, passou para a história como tendo combatido o terrorismo sem medidas de exceção ou tribunais ad hoc (MAIEROVITCH, 04/02/2009: 17).

Pode-se notar claramente que, aqui, a legitimação do testemunho é colocada não tanto em termos de um trecho de vida que justifica a fala ou de uma experiência direta do evento discutido, mas sim, em função da aquisição de um saber específico, que autoriza o retratado a opinar sobre o caso. Os marcadores de pressuposição (como "estar na frente nas apurações") denotam a aquisição de conhecimento adquirido e autoridade e subentendem mesmo uma articulação de saberes que confere legitimidade à fala.

Ao propor um conjunto de narrativas que toma como princípio norteador o enfrentamento dos diversos testemunhos emitidos, as reportagens sobre o caso Battisti contêm mesmo as variações mais frequentes quanto aos tipos de vinculação de coexistência "pessoa-ato" na fase de crítica do testemunho que podemos encontrar nas narrativas jornalísticas. A partir do exposto, podemos delinear três linhas bastante claras e recorrentes no corpus como um todo.

A primeira diz respeito a um tipo de testemunho que é acreditado ou descartado a partir de uma circunstância de vida que funciona como um elemento explicativo da fala dado a priori. Este é o caso dos primeiros exemplos citados e está relacionada a alguns momentos da biografia do retratado que são postos de forma a justificar a declaração emitida por ele. Um outro tipo diferente é instaurado quando a testemunha é acreditada a partir de uma experiência direta do ocorrido, na forma de um "eu vi" (como no exemplo da namorada de Battisti ou do depoimento do filho de uma de suas possíveis vítimas). Por fim, podemos ter um tipo de testemunho que é acreditado por um saber ou por uma prática específicos que autorizam o testemunhante a se pronunciar sobre o caso, assumindo mesmo a forma de um "eu sei".

Podemos examinar estas categorias com um pouco mais de atenção.

Quanto à primeira, a saber, a que diz respeito aos testemunhos que são acreditados ou desmerecidos a partir de uma circunstância de vida que funciona como um elemento explicativo da fala dado a priori, a reportagem da Carta Capital "Renasce o centrão", traz um bom exemplo a respeito deste funcionamento. Logo depois de José Sarney ter assumido a presidência do Senado, a reportagem destaca que, em seu discurso de posse, ele "partiu para a defensiva, lembrando a longa trajetória democrática e se dizendo um inovador. 'Não me chamem de retrógrado', disse o ex-presidente, 
ressaltando que fez reformas administrativas no Maranhão quando foi governador". Esta fala, no entanto, passa pelo crivo da revista nos seguintes termos: "Parênteses: no discurso, nenhuma palavra sobre o fato de o Maranhão ser o estado com alguns dos piores índices socioeconômicos do Brasil. Nem sobre ter sido ele, Sarney, responsável pelo fracasso da emenda das Diretas Já - acordo que empurrou o País a uma transição mambembe e que, por força das coincidências, o levou à Presidência da República" (MENEZES, 11/02/2009: 23).

Esse mesmo mecanismo pode ser notado em um quadro colocado em uma reportagem da revista Veja em que ela analisa, trecho a trecho, um pronunciamento de Sarney. Na passagem, "Sarney disse na tribuna que foi o "único governador que não apoiou o AI-5", a matéria relembra que "no dia seguinte ao da Promulgação do Ato Institucional $n^{\circ} 5$, em Dezembro de 1968, Sarney, à época governador do Maranhão, publicou nota de apoio aos militares nos jornais do estado" (CABRAL, 12/08/2009: 53).

Não é difícil perceber a disjunção "fala-ato" operada pelo fato histórico evocado. Ao passo que determinados marcadores de pressuposição - como "nenhuma palavra sobre... nem" - delineiam o campo comum que torna possível que o presente seja entendido a partir de certa luz fornecida pelos atos do passado, os subentendidos colocam em operação um movimento de retirada de máscaras. A pretensa aura progressista que a fala do Senador evoca é desconstruída a partir deste chamado à memória de sua posição contrária a campanha das Diretas Já, ligando a biografia do retratado a atos retrógrados e antidemocráticos. A fala do Senador é, desta forma, desacreditada uma vez que o seu comprometimento moral com o testemunho relatado é posto à prova através da evocação de algumas marcas biográficas de seu passado.

O fato de o Senador ter sido contrário à Campanha das Diretas Já passa a funcionar como um mecanismo de julgamento de sua fala. É este trecho de vida que permite que seu testemunho seja desconstruído e descartado. Ele adquire uma força metonímica e é o principal articulador de sentido para o entendimento do que é posto pelo testemunhante.

Embora o fato evocado seja público, é interessante observamos a sua aparição na narrativa da reportagem no contexto em que esta foi produzida - um momento de descrédito público da figura de José Sarney e de um questionamento amplo sobre seus atos no governo atual. Em momentos menos inglórios, este episódio raramente aparecia.

É o que atesta Rafael Fortes (2006) ao estudar as narrativas das revistas IstoÉ e Veja sobre o Plano Cruzado e José Sarney, no período de Março a Abril de 1986. Segundo seu estudo, não só a figura de Sarney foi intimamente relacionada à de 
Tancredo como um dos grandes defensores da democracia, neste período, como também foi reservado um conveniente esquecimento quanto à atuação de Sarney no período do regime militar. Neste intervalo, isso pode ser percebido "pelo expressivo número de vezes em que expressões como 'mobilização pela democracia' e 'campanha de 1984', aparecem na amostragem pesquisada" (FORTES, 2006: 08). O autor encontrou apenas um artigo jornalístico no qual o passado político de Sarney foi apresentado claramente como oposto às Diretas ou a Tancredo Neves.

Os eventos ou relances de uma vida que são evocados, muito embora não sejam falsos ou mentirosos não são, no entanto, nem uma marca indelével, nem uma referência necessária de uma personalidade. Os eventos privilegiados na urdidura de enredo são, em função disso, fundamentais para a construção de sentido que se pretende confirmada.

As revistas estão repletas de reportagens que utilizam construções textuais semelhantes. Podemos citar uma reportagem de Carta Capital sobre os problemas políticos em Honduras onde, a respeito da deposição e do retorno ao país de José Manuel Zelaya, o embaixador dos Estados Unidos na OEA, Lewis Amselem condena o fato. Segundo a reportagem, ele “chamou o retorno de 'irresponsável e tolo', ridicularizou Zelaya por agir como 'se estrelasse um filme antigo' e responsabilizou ' aqueles que facilitaram a sua volta' pela violência". Para desqualificar a sua fala, a revista, que publicou várias matérias pró-Zelaya, utiliza os seguintes termos "Amselem, ex-assessor do SouthCom herdado do governo Bush Jr., trabalhou na embaixada da Guatemala de 1988 a 1992 e fez o que pôde para encobrir o massacre de indígenas e o sequestro, tortura e violação de uma freira estadunidense" (COSTA, 07/10/2009: 30).

Em uma reportagem sobre o ator Robin Williams (a respeito de seu comentário em torno da realização das Olimpíadas no Rio de Janeiro), a revista Época faz o seguinte comentário: "o ator - ex-viciado em cocaína - disse que a concorrência do Rio de Janeiro foi desleal: enquanto a cidade americana mandou Oprah Winfrey e Michelle Obama, a brasileira teria enviado '50 strippers e meio quilo de pó'. Mais uma vez, Williams meteu o nariz onde não devia" (FERNANDES, 07/12/2009: 15). Ao resgatar o fato de que o ator foi viciado durante a juventude, a revista qualifica a sua fala. É como se perguntasse "quem este homem é para falar do Brasil deste jeito?". A reportagem mostra como "ao mesmo tempo em que fazia sucesso na TV como um alienígena, Williams vivia em outro mundo, embalado pela cocaína" (FERNANDES, 07/12/2009: 16). 
No caso das funções narrativas de trajetórias pessoais ligadas à função testemunhal, temos que 16,13\% das matérias do corpus que se enquadram nesta categoria de um testemunho que é acreditado (ou desmerecido) a partir de uma circunstância de vida que funciona como um elemento explicativo da fala dado a priori.

A divisão desta categoria em cada revista analisada pode ser observada pela seguinte tabela:

\begin{tabular}{ccc} 
& $\begin{array}{c}\text { Biografias - função } \\
\text { testemunhal }\end{array}$ & $\begin{array}{c}\text { Situação que qualifica } \\
\text { a fala } \boldsymbol{a} \text { priori }\end{array}$ \\
\cline { 2 - 3 } Veja & 163 & $31(19,01 \%)$ \\
Época & 235 & $31(13,19 \%)$ \\
IstoÉ & 179 & $24(13,4 \%)$ \\
Carta Capital & 204 & $40(19,60 \%)$ \\
\hline
\end{tabular}

Uma característica interessante a ser notada a respeito das formas pelas quais o testemunho pode ser acreditado é que as informações adicionadas são, em grande parte dos casos, apenas funções catálises, tal como exposto por Barthes. Ou seja, sua inserção não tem uma grande influência no desenvolvimento da narrativa, mas, não obstante isso, elas engendram sentidos que não podem ser ignorados para entendermos sua significação. Isso é bastante recorrente, especialmente, nas matérias em a testemunha é acreditada a partir de uma experiência direta do ocorrido.

Como exemplo, podemos mencionar a já citada entrevista que Veja fez com o Senador Jarbas Vasconcellos, sobre os casos de corrupção e de fisiologismo no PMDB. Em todos os textos que a revista publicou sobre estas declarações, era enfatizado o longo tempo em que o Senador era afiliado ao partido e sua vivência como testemunha ocular dos escândalos que eram ali perpetrados.

Assim, a revista coloca, a respeito de suas declarações - de que "boa parte do PMDB quer mesmo é corrupção" e que "a maioria de seus quadros se move por manipulação de licitações e contratações dirigidas" - que "não se trata de percepção ou impressão, mas de uma constatação feita por um político com 43 anos de vida pública, fundador da agremiação e conhecedor de suas entranhas" (CABRAL e ESCOSTEGUY, 25/02/2009: 46). A experiência direta, portanto, acredita o testemunho e faz com que ele se torne digno de relevância.

Esta autoridade do vivido daquele que testemunha também é evocada por Sócrates em sua coluna na Carta Capital quando, ao comentar o desempenho da equipe 
do Palmeiras, afirma que "a experiência e certo conhecimento do ser humano, adquirido nesses mais de 30 anos de contato com os amantes do futebol, me oferecem a possibilidade de entender até o que ainda não ocorreu" (SÓCRATES, 11/03/2009: 62). Ou, ainda, na revista Época que, ao comentar o aniversário da queda do Muro de Berlim mostra uma foto do editor da revista, Hélio Gurovitz, "aos 21 anos, quando golpeava o símbolo da Guerra Fria” (GUROVITZ, 02/11/2009: 08).

No corpus pesquisado, este tipo de material corresponde a $34,18 \%$ das funções narrativas de trajetórias pessoais referentes à fase crítica do testemunho.

Em cada uma das revistas analisadas, ela obedece à seguinte proporção:

\begin{tabular}{ccc} 
& $\begin{array}{c}\text { Biografias - função } \\
\text { testemunhal }\end{array}$ & Experiência direta do ocorrido \\
Veja & 163 & $54(33,12 \%)$ \\
Época & 235 & $64(27,23 \%)$ \\
IstoÉ & 179 & $57(31,84 \%)$ \\
Carta Capital & 204 & $92(45,09 \%)$ \\
\hline
\end{tabular}

Por fim, a última categoria de funções narrativas de trajetórias pessoais citada, ou seja, aquela no qual o testemunho é acreditado a partir de um saber ou de uma prática específicos é a mais frequente em quase todas as revistas (exceto em Carta Capital, onde a experiência direta do vivido é predominante) e também a mais prosaica de todas as que citamos até agora. Dificilmente as entrevistas principais de uma revista não possuem algum dado histórico biográfico desta ordem e elas são também bastante comuns nas consultas aos especialistas sobre temas específicos e/ou científicos.

Asserções do tipo "James Baker, secretário do Tesouro de Ronald Regan, (...) disse (...)" (PETRY, 11/03/2009: 99) ou, ainda, "desde o final da década de 1980, Adrian Raine, um professor de psicologia da Universidade do Sul da Califórnia, nos Estados Unidos, estuda o comportamento de homicidas" (AZEVEDO, 14/09/2009: 80), são apenas exemplos de um procedimento que é, em geral, bastante comum no jornalismo.

É justamente a referência ao saber acumulado durante certo período de carreira que autoriza os testemunhantes a falar sobre a temática que será desenvolvida no restante da entrevista. É um determinado tipo de saber específico justifica e acredita a posição tomada pelo testemunhante, de forma que determina o lugar de onde ele fala e credencia a testemunha como já validada. 
Esse credenciamento do testemunho pode parecer banal, mas, muitas vezes, implica também uma determinada tomada de posição. Em uma matéria sobre os estudos de Andrés Carrasco, um geneticista que se opõe ao uso do herbicida Roundup, produzido pela Monsanto, uma vez que, segundo ele, o produto seria capaz de causar sérios danos à saúde, o currículo do cientista é exposto nos seguintes termos:

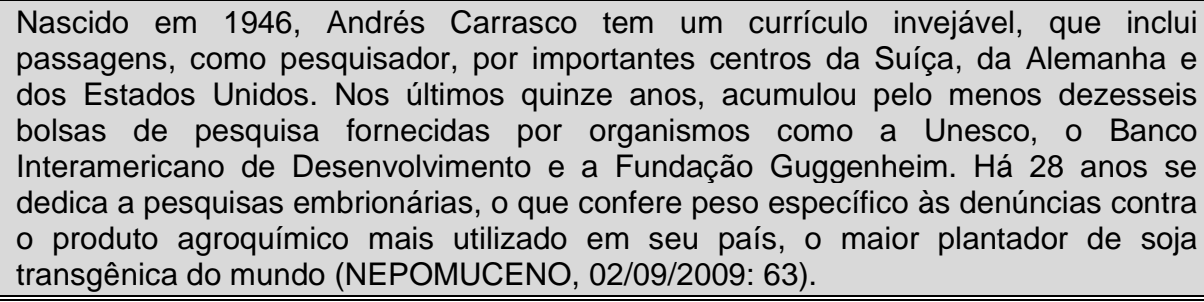

O "currículo" da Monsanto, por outro lado, é descrito em termos bem menos lisonjeiros. Segundo a reportagem, "a Monsanto, por sinal, tem experiência em criar herbicidas que destroem plantações e vidas humanas. Afinal, foi ela que desenvolveu o 'agente laranja' utilizado para desfolhar florestas durante a Guerra do Vietnã, e que provocou centenas de vítimas nas próprias tropas dos Estados Unidos, além de ter dizimado milhares de vietnamitas" (NEPOMUCENO, 02/09/2009: 63).

Estas articulações biográficas em torno da competência do entrevistado, portanto, nem sempre são tão inocentes e, por vezes, engendram significações curiosas. Outro exemplo bastante interessante a este respeito está na reportagem "O peso de uma condenação", da revista IstoÉ, onde era discutida a prisão de Eliana Tranchesi, dona da Daslu. Contrária ao ato ${ }^{46}$, a revista entrevista "Hélio Bicudo, 86 anos, vice de Marta Suplicy na Prefeitura de São Paulo e com larga militância em defesa dos direitos humanos e dos perseguidos pelo regime militar. 'O direito penal brasileiro está dando muito mais importância ao problema financeiro do que à vida"' (SUASSUNA, 01/04/2009: 77).

A biografia do testemunhante, ao atestar a sua competência ou o seu saber específico dentro da área da militância em defesa dos perseguidos do regime militar diz algo a mais do que a mera experiência profissional do entrevistado. Ela não deixa de

\footnotetext{
${ }^{46}$ No editorial desta edição, IstoÉ coloca que no caso da prisão de Eliana Tranchesi "há sinais de que a nova investida passou do tom. A OAB considerou arbitrária a prisão da executiva, que foi condenada em primeira instância e não apresentava ameaça à investigação" (MARQUES, 01/04/2009: 20). Na reportagem correspondente, a prisão de Tranchesi é tida como uma punição mais severa do que a reservada para personagens como Antônio Pimenta Neves, Suzane von Richthofen e Fernandinho BeiraMar.
} 
engendrar uma comparação, no nível dos subentendidos, entre o caso de Tranchesi e de outros oprimidos por razões políticas.

Mais do que uma mera informação, portanto, a fala diz respeito a um posicionamento sobre o fato.

Este tipo de função narrativa comporta $49,67 \%$ das narrativas de trajetórias pessoais que cumprem a função de acreditar um testemunho. Se considerarmos cada veículo individualmente, a distribuição deste material se dará da seguinte forma:

\begin{tabular}{ccc} 
& $\begin{array}{c}\text { Biografias - função } \\
\text { testemunhal }\end{array}$ & Saber sobre o relatado \\
Veja & 163 & $78(47,85 \%)$ \\
Época & 235 & $140(59,57 \%)$ \\
Istó́ & 179 & $98(54,74 \%)$ \\
Carta Capital & 204 & $72(35,29 \%)$ \\
\hline
\end{tabular}

A partir do exposto, podemos notar muito claramente que as evocações do passado ligadas à trajetórias pessoais que funcionam na narrativa jornalística como funções catálises de credenciamento ou crítica do testemunho, obedecem dentro da lógica dos pressupostos e subentendidos a um esquema geral da seguinte ordem:

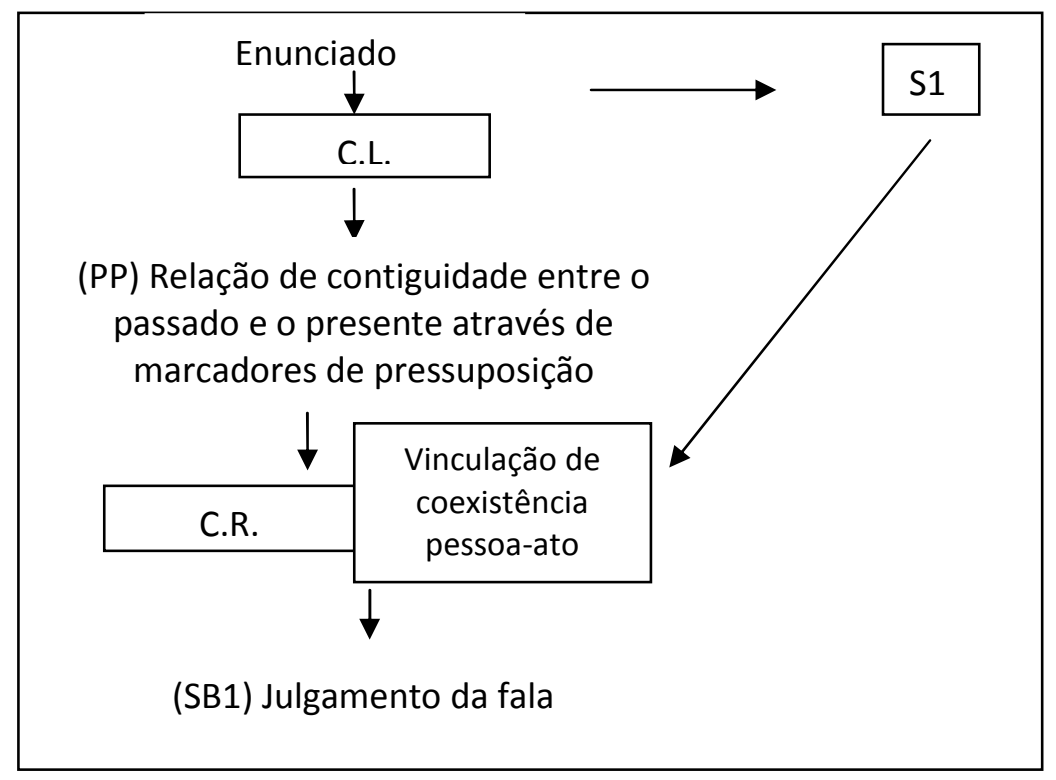

O ato testemunhal, como já havíamos colocado, implica uma série de práticas de reconhecimento vinculadas à afirmação de um comprometimento moral do testemunhante e ligadas intimamente aos padrões sociais de representação. Os dados históricos que assumem uma função ou sequência narrativa de trajetórias pessoais 
dentro de um texto jornalístico mais amplo atuam muitas vezes, neste sentido, aludindo à fiabilidade ou ao descrédito do testemunho apresentado.

Os pressupostos evocados nestas inserções de dados históricos estão relacionados à construção de um solo a partir do qual o presente se relaciona com o passado através de uma relação de contiguidade. Os subtendidos, por sua vez, estão relacionados à prova do comprometimento moral daquele que testemunha ou, em outras palavras, ao reconhecimento e legitimação de sua posição como testemunhante e do julgamento de sua fala através da vinculação de coexistência "pessoa-ato".

\section{Vinculação pessoa-ato como doador de legitimidade para a ação:}

A vinculação de coexistência "pessoa-ato" é bastante comum em reportagens jornalísticas mesmo quando está desligada da esfera do testemunho, embora muitas vezes apresente um funcionamento parecido. A questão da legitimidade, neste caso, se desloca do julgamento do testemunho (da fala) em direção ao julgamento da ação. Os atos do presente são re-significados (ou re-apresentados) em função dos acontecimentos do passado evocado, mostrando mesmo a relação exposta por Perelman e OlbrechtsTyteca (1996) entre algo tido como mais permanente e um evento transitório.

Tanto no caso da leitura de uma vida tal como é feita na fase de credenciamento do testemunho, quanto no caso de uma apreciação de determinada ação, está implicada a construção, pelo jornalista de "uma teia interpretante, graças a qual apreende, capta, 'lê' a vida de alguém, tal como a aranha à mosca" (PIGNATARI, 1996: 13). Isso quer dizer que os dados e os eventos evocados para que a palavra e/ou ação sejam dotadas de crédito ou de desmerecimento são organizadas e hierarquizadas tal como um biodiagrama. Para Pignatari, é esta montagem em função de um determinado design que forma o que se costuma chamar de "significado" da vida que está sendo exposta. Eventos pontuais dotam de sentido os outros e adquirem mesmo uma força explicativa. A escolha, portanto, de diferentes acontecimentos biográficos-chave podem determinar diferentes significados para a vida que está sendo ali narrada.

E isso acontece, justamente, porque estas ocorrências singulares adquirem uma força metonímica: elas explicam toda uma vida e todos os atos expostos são subordinados a ela na construção dos sentidos.

A metonímia se refere, justamente, a construção de determinados campos semânticos nos quais "o narrador rompe, de maneira calculada, as regras de combinatória das figuras, criando uma impertinência semântica, que produz novos sentidos" (FIORIN, 2005: 118). Ela instaura, assim, a possibilidade de uma outra leitura 
de um termo, dentro de um determinado contexto e, mais do que uma mera substituição de palavras, ela implica mesmo uma relação de inclusão entre duas situações postas.

Como explica Fiorin (2005: 119), as metonímias devem ser lidas como conectores de isotopia num texto pluri-isotópico, de forma que um determinado termo A da isotopia 1 passe a significar A' na isotopia 2. Uma vez que elas dizem respeito a relações estabelecidas entre significados de um mesmo termo pertencente a vários campos isotópicos diferentes, as metonímias serão classificadas como tais quando entre A e A' "houver uma inclusão num mesmo conjunto de traços semânticos ou numa mesma totalidade".

Isso tem implicações importantes para as construções de sentido dentro do jornalismo, pois, como coloca Hayden White (1994: 92) o uso de um determinado tropo na construção da explicação formal de um acontecimento está normalmente relacionado ao fornecimento da "direção que o pensamento poderia tomar em sua tentativa de dar sentido a áreas da experiência ainda não consideradas como cognitivamente garantidas pelo senso comum, pela tradição ou pela ciência”. Em outras palavras, o próprio tropo já oferece determinados modelos de explicações causais, de modo que a relação causaefeito de um mesmo evento pode ser aclarada de maneiras diferentes, conforme se adote um modelo metafórico, metonímico, irônico ou sinedótico de explicação.

Assim, ao passo que uma explicação metafórica do mundo explanaria os fenômenos baseada em uma busca de similitudes entre os eventos de modo que ela possa catalogar seus atributos específicos, bem como demarcar suas diferenças manifestas; uma explicação metonímica buscaria entender as relações subjacentes entre uma parte e um todo dentro de um mesmo campo fenomênico.

Esta força metonímica do relato biográfico e o jogo que ele instaura entre o que é tido como transitório e o que é próprio do sujeito podem ser claramente observados nas reportagens, como tentaremos mostrar nos exemplos a seguir.

Dentro da temática dos escândalos de corrupção no Congresso as ações de diversos personagens foram julgadas de acordo com algumas notas biográficas evocadas nas revistas pesquisadas. Elas foram usadas para construir este significado da vida e esta maneira bastante específica de compreensão de mundo, nas palavras de White.

A vinculação de coexistência "ato-pessoa" que concerne ao julgamento da ação funciona de uma maneira similar a que expusemos no caso do testemunho como fica bastante claro, por exemplo, quando Ruth de Aquino - ao comentar o caso de Edmar Moreira, corregedor da Câmara que possuía um castelo em Minas Gerais - liga este evento do tempo presente a toda uma série de acontecimentos da vida do deputado: 
Edmar, filho de carteiro de Juiz de Fora e de professora primária, deve ter tido infância difícil com sete irmãos. Dizem as fofocas em Minas que sua carreira militar acabou por ciúme explícito. O capitão da PM Edmar humilhou um rapaz que cortejara sua mulher. Com escolta policial, teria obrigado o engraçadinho a entrar de pijama numa festa de Réveillon no Clube Dom Pedro II. Só então, afastado da ativa, Edmar descobriu o caminho da riqueza. Mudou-se para São Paulo, formou-se em direito, fundou uma empresa de segurança e tornou-se deputado federal, primeiro no partido de Collor, depois no partido de Maluf. Foi quando começou a entender o significado da palavra fraternidade (AQUINO, 09/02/2009: 106).

O caso da construção do castelo, mais do que um evento pontual ou um desvio na vida do parlamentar, ganha mesmo uma outra tonalidade significativa quando é exposto como um desdobramento de uma série de atos reprováveis cometidos durante uma vida. Esta coerência posta na urdidura de enredo joga com determinadas expectativas sociais que envolvem a ideia de que um ato de mau-caratismo nunca vem sozinho. A humilhação a um subordinado de farda ganha mesmo uma força metonímica no discurso na medida em que este fato é tomado como inclusivo, ganhando a força de uma explicação, dentro de um mesmo conjunto de traços semânticos (que incluem o mau comportamento como parlamentar) e não como um evento isolado.

Se adotarmos a visão de White de que a utilização da metonímia na construção da explicação formal implica uma forma específica de compreensão de mundo, poderemos notar que está em jogo uma visão bastante mecanicista de ligação entre os eventos. Isso porque, para White, a metonímia, sendo redutiva em suas operações, forneceria um modelo da forma de explicação que se "caracteriza por apreender o campo histórico como um complexo de relações entre parte e todo e por tentar compreender esse campo em função das leis que ligam um fenômeno a outro como uma causa associada a um efeito". Os modos metonímicos de explicação, desta forma, são caracterizados, assim, por "atribuir prioridade às partes para a imputação de sentidos a qualquer totalidade putativa que se apresente à consciência” (WHITE, 1994: 92). Ora, são exatamente estas as características de uma explicação mecanicista do mundo.

Ao atribuir ao evento da humilhação do subordinado a força explicativa que uma parte poderia dotar ao todo, os marcadores de pressuposição (“começou a aprender", por exemplo) equacionam uma relação necessária entre os fenômenos do presente e do passado a partir de um modelo já estruturado de explicação. Já os subentendidos estão relacionados mesmo a este nível de julgamento da ação que estabelece negatividade a determinados eventos e a determinadas características escolhidas e expostas. 
A adoção deste modelo de explicação é mesmo bastante frequente. Ainda dentro da temática dos escândalos políticos do ano de 2009, a revista Época descreve o diretor de Recursos Humanos do Senado, João Carlos Zoghbi, da seguinte forma:

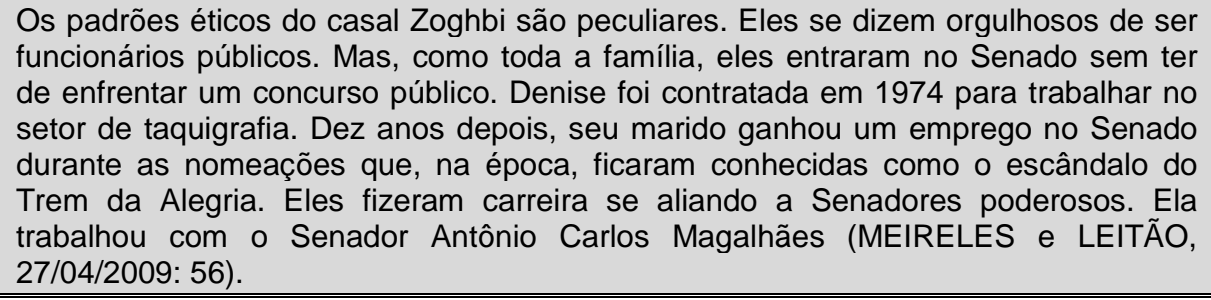

Nesta reportagem também é bastante claro o modo como as contratações sem concurso adquirem uma força metonímica para os escândalos recentes em que o diretor estava envolvido, a saber, a criação de empresas de fachada que faziam negócios com o Senado e utilizavam até mesmo sua ex-babá como laranja. De um modo geral, a falta de concurso tem pouca relação com os atos recentes cometidos, mas eles não deixam de significar, dentro da urdidura de enredo proposta, certa coerência de ações esperada entre dois atos reprováveis.

A reportagem "O dono do Senado", da Carta Capital de 08/04/2009, utiliza o mesmo recurso para explicar a influência de Renan Calheiros no Senado. Aqui, é aludida uma suposta regularidade de ação nos diversos governos nos quais o Senador teve uma participação ativa. É ela que confere o "significado" ou "sentido" de sua vida e ganha uma força metonímica de explicação que contribui na formação dos julgamentos de sua ação atual no Senado:

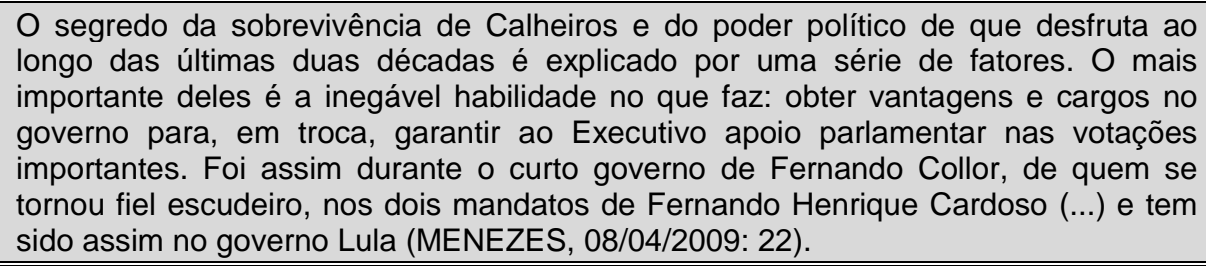

A atuação de Calheiros no Senado é avaliada, nos termos postos na reportagem, tendo como um dos parâmetros de explicação a sua atuação nos governos anteriores. $\mathrm{O}$ julgamento da ação é posto nos termos de uma regularidade no comportamento aludido por marcadores de pressuposição como "explicado", "foi assim... tem sido assim", entre outros. Os subentendidos, através da vinculação de coexistência "pessoa-ato" e da força da explicação metonímica conferida à narrativa dizem respeito ao julgamento da ação e 
obedecem, de uma forma geral, ao seguinte esquema, que pode ser estendido às reportagens anteriormente citadas:

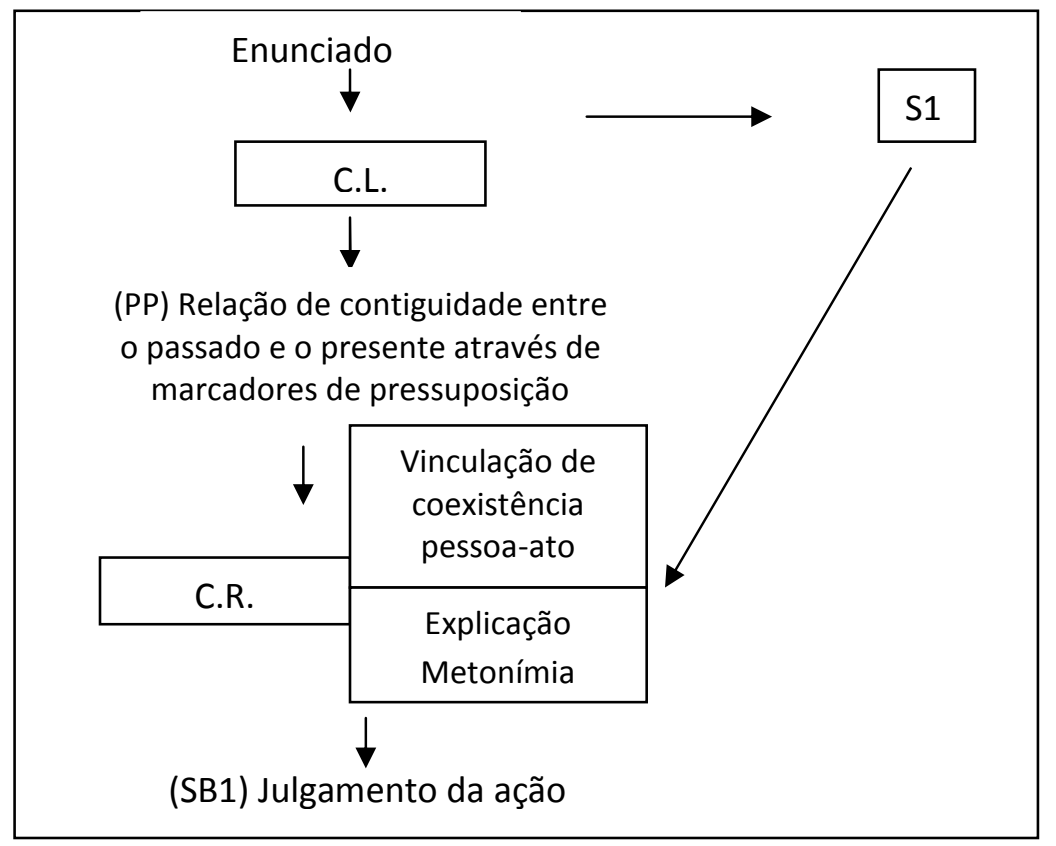

Há, nestas reportagens, de forma clara um tipo de discurso subentendido que diz respeito à forma como o jornalista deve se portar diante de uma investigação da notícia. Ele está ligado, se utilizarmos os termos de Carlos Eduardo Lins da Silva (1990: 34) ao "aceitamento, em maior ou menor medida, de que uma das funções primordiais da imprensa é exercer a vigilância sobre a ação do Estado", o que é chamado de watchdog role.

Este papel de cão de guarda colocado por Lins da Silva como um aceitamento, ou em termos mais precisos, como uma estória que os jornalistas contam a si próprios sobre si próprios (GEERTZ, 1978) como forma de costurar sua identidade profissional, pode ser percebido facilmente nas falas dos próprios profissionais da imprensa como, por exemplo, quando Ricardo Kotscho (1986: 34) coloca que "em qualquer época, uma das funções principais do jornalismo é a de fiscalizar os poderes públicos e é o repórter o encarregado desta tarefa".

Trata-se de uma noção surgida apenas em meados do século XIX quando "os jornalistas mudaram o seu discurso de watchdogs partidários para watchdogs independentes e o 'divórcio' da imprensa com os partidos políticos foi teorizado. A mídia se torna independente para poder manter a democracia, pois o partidarismo se torna veneno para ela" (VENANCIO, 2009: 5). É somente neste período que este critério passa a funcionar como definidor da competência do jornalista perante seus 
pares e a sociedade e há a expansão de um novo pólo ideológico a partir da noção de que a imprensa (como um produto comercializável e rentável), é que deveria cumprir tanto o papel de promotor da "liberdade negativa" (ao "vigiar o poder político e proteger os cidadãos dos eventuais abusos dos governantes") quanto da "liberdade positiva" (ao "fornecer aos cidadãos as informações necessárias para o desempenho de suas responsabilidades cívicas") (TRAQUINA, 2005a: 50).

Há, portanto, um lugar no imaginário jornalístico a ser preenchido pela devassa da vida daqueles que estão no poder. É parte de sua função, se falarmos em termos das metanarrativas que sustentam a prática, a investigação da probidade daqueles que exercem funções públicas e parte desta investigação envolve, logicamente, os passos biográficos seguidos por estas pessoas no passado.

Para além dos efeitos de sentido que certamente surgem a partir das evocações dos dados biográficos, há mesmo uma lógica jornalística imbuída dentro destas remissões que evocam o passado dos governantes como forma de julgar metonimicamente os atos do presente.

Esta lógica pode ser percebida bastante claramente também em reportagens em que o funcionamento metonímico é exposto de uma forma menos direta, de sorte que a correlação entre o todo de uma vida e de sua parte mais significativa é posto de uma forma mais enviesada. Isso porque, em algumas reportagens, a remissão a eventos biográficos funcionam como uma forma de demonstrar aspectos inesperados ou pouco divulgados a respeito de alguns personagens que tem suas biografias solidamente conhecidas por outros fatores ou por outras passagens. Não obstante, são informações que também contribuem de uma forma bastante acentuada para a formação dos julgamentos da ação presente destes retratados.

Neste aspecto, a reportagem "O dia de índio de Joaquim Barbosa", da revista $V e j a$ - a respeito da briga deste com Gilmar Mendes em meio a uma sessão do STF - é bastante significativa. Como é de domínio geral, o ministro Joaquim Barbosa é conhecido - e isso foi, na época, amplamente divulgado pelas outras três revistas como o primeiro ministro negro a tomar posse no Supremo Tribunal Federal, em 2003. Muitas das revistas construíram suas reportagens nos termos de que isso seria uma das particularidades que o diferenciariam de Calheiros, ou seja, o fato de ser parte de um grupo tido como subordinado e que raramente alcançaria altas posições no poder.

A reportagem na revista Veja, no entanto, mostra um perfil diferente daquele posto nas outras revistas: "ao contrário do que a altercação da semana passada sugere, Mendes e Barbosa têm muitos pontos de comunhão profissional e pessoal. Ambos 
estudaram na Universidade de Brasília, ingressaram no Ministério Público por concurso e complementaram seus estudos no exterior". A revista acrescenta, ainda, que "Barbosa, filho de pedreiro, que sempre estudou em escola pública (...) foi escolhido por seus inegáveis méritos jurídicos, mas também pela disposição do presidente da República de nomear alguém com o perfil de Barbosa" (OLTRAMARI, 29/04/2009: 78).

Ao realocar os dados biográficos do ministro Joaquim Barbosa, os subentendidos mobilizados também se tornam inteiramente outros. Embora esteja preservada a coerência esperada (e posta através dos pressupostos) entre o passado biográfico e as atuações no presente - fundamentais para a formação do julgamento - ao aproximar as biografias de Calheiros e Barbosa, a revista engendra uma narrativa que realoca o papel que tradicionalmente era ocupado pelo segundo. A asserção de que Mendes e Barbosa possuem biografias similares barra, de certa forma, a asserção de que um deles seja colocado como um herói ou como mais correto durante a discussão como foi colocado em outras publicações ${ }^{47}$. E, de fato, este é o tom que o restante da matéria busca confirmar.

Observa-se, aqui, claramente, o mecanismo metonímico de explicação e a correlação de coexistência "pessoa-ato" (mesmo que ele se coloque a partir de uma informação apresentada como inédita ou inesperada) combinada com este lugar imaginário de que o jornalista, como watchdog político, tem a função de destacar pontos pouco conhecidos sobre os detentores do poder.

Esta coerência de ações esperada entre uma narrativa de vida e a pontualidade de uma ação não se dá apenas em reportagem sobre escândalos políticos ou que estão relacionadas aos meandros do poder. Trata-se mesmo de um recurso que pode ser comumente encontrado em perfis biográficos cotidianos. Não raro estas informações de vida apontam para o compartilhamento de valores em estórias que mostram a trajetória

\footnotetext{
${ }^{47}$ Para efeitos de comparação, podemos citar a reportagem publicada sobre este assunto na revista Carta Capital. Segundo ela, "Barbosa deu (...) voz a uma indignação popular que só tem encontrado espaço nas sessões de cartas da mídia tradicional". Para confirmar este posicionamento, a favor de Barbosa, ela elenca uma série de outros dados biográficos a respeito do ministro que, embora não se encaixem em nosso corpus, dizem respeito ao posicionamento da revista. Segundo ela, embora o restante da imprensa tenha festejado a atuação de Barbosa no episódio do Mensalão, "bastou, no entanto, atritar-se com Mendes para Barbosa ver seu nome associado à palavra 'destemperado' e a sofrer todo tipo de insinuação, inclusive a de ter sido indicado para o tribunal para compor uma velada cota racial. O ministro é o primeiro negro a ocupar uma cadeira no Supremo". Além disso, acrescenta, depois de delinear um perfil pouco lisonjeiro de Mendes que "Barbosa, ao contrário, é um defensor incondicional do Ministério Público e tem um relacionamento excelente com os promotores de Justiça e procuradores. Não teme ser 'corporativo', como o acusou Mendes, ao defender publicamente as ações do MP. Mais uma diferença. Barbosa acredita se diferenciar dos colegas de toga justamente por ser uma pessoa simples" (MENEZES e FORTES, 29/04/2009: 20-24).
} 
de personalidades importantes, não raro pontilhadas por elementos que remetem a dons que se mostraram desde cedo e/ou que remetem a superações de obstáculos.

Ao noticiar o trabalho com células-tronco da UFRJ liderado Stevens Rehen, Época coloca que este cientista "é um caso de pesquisador vocacional. Desde criança demonstrava curiosidade científica. Os presentes que marcaram sua infância foram um kit de química, um livro sobre Charles Darwin e um bongô" (SEGATTO, 23/03/2009: 87).

Para Veja, o trabalho talentoso do paleoartista (especialista em recriar representações de espécies extintas) Viktor Deak também já podia ser vislumbrado desde cedo: "tudo na vida do artista parece exaltar a evolução da espécie. A começar por seu local de nascimento, em Budapeste, uma região fértil em fósseis de neandertais, Homo erectus e Homo heidelbergensis. A esposa, Xochitl, nome de origem asteca (significa flores), é descrita por ele como 'a mais bela que nossa espécie jamais produziu" (VENTUROLI, 23/09/2009: 130).

Os elementos que mobilizam as construções de sentido em matérias como estas são similares aos que estão presentes nas matérias que citamos anteriormente, a saber, uma construção explicativa metonímica do relato e a vinculação de coexistência "pessoa-ato" para o julgamento da ação. Elas nos ajudam a delinear com mais clareza, contudo, uma outra característica que também está presente nas matérias anteriores e que se apresenta de forma muito inteligível aqui. Estamos nos referindo, especificamente, às questões de uma construção teleológica de um trajeto de vida.

Isso porque são nestes tipos de matérias que podemos notar de forma mais clara aquilo que Pierre Bourdieu chama de ilusão biográfica e que pode ser delineada por esta busca pelo caminho, pelo percurso que transformou determinada pessoa no que ela é ou no que ela faz. Isso porque está posto, nestas reportagens, uma aceitação da possibilidade de um trajeto retilíneo e vocacional na vida - tal como "um caminho que percorremos e que deve ser percorrido, um percurso orientado (...) que tem um começo ('uma estreia na vida'), etapas e um fim, no duplo sentido, de término e de finalidade ('ele fará seu caminho' significa ele terá êxito, fará uma bela carreira)” (BOURDIEU, 1996: 183).

Isto é exatamente o que expressa a noção de ilusão biográfica e, conformar-se com isso, segundo o autor, é "aceitar tacitamente a filosofia da história no sentido de sucessão de acontecimentos históricos, Geschichte, que está implícita numa filosofia da história no sentido de relato histórico, Historie" (BOURDIEU, 1996: 183-184). 
Este tipo de construção discursiva de uma vida, - que diz respeito, justamente, a determinados arranjos biográficos que parecem delinear um plano de ação para a realização de um ato -, para Bourdieu, podem ser pensadas a partir da noção de projeto original de Sartre. Este conceito é entendido como "o centro de referência para uma infinitude de significados polivalentes" (SARTRE, 2005) em um indivíduo. Assim, ele tenta dar conta de uma espécie de costura entre os diversos comportamentos, emoções e raciocínios do sujeito e tenta extrair o significado destes aspectos em direção a um fim. Ele pode ser entendido mesmo como "o nexo que define o sentido da vida de alguém" 48 e é justamente a compreensão deste nó que articula todos os sentidos polivalentes, ou em outros termos, desta unificação irredutível que forma o projeto do ser, que Sartre pode delinear mesmo uma proposição de um tratamento clínico.

É também em torno desta compreensão de uma lógica significativa para o sujeito que muitas biografias se estruturam. Pierre Bourdieu diz mesmo que esta noção de projeto original apenas coloca de modo explícito o que já se encontra nas biografias comuns e nas histórias de vida de modo implícito através de expressões como "sempre", "tudo" ("tudo na vida do artista") ou "desde" ("desde criança demonstrava curiosidade científica").

São estes marcadores de pressuposição que marcam a relação de continuidade entre o presente e o passado de forma que ele é exposto como um trajeto em direção a uma finalidade, segundo relações inteligíveis.

Os subentendidos, relacionados ao julgamento da ação pontual, se deslocam, neste caso, para o próprio julgamento do trajeto. É a partir do reconhecimento de um caminho posto a partir de determinados eventos significativos que se julga a ação do retratado, reconhecendo sua excelência em sua área ou um demérito de suas ações. Da mesma forma que a crítica do testemunho envolvia um tipo de reconhecimento do comprometimento moral daquele que fala, aqui, também está em jogo uma espécie de reconhecimento do compromisso daquele que age - compromisso este assegurado pelo cumprimento imaginário de um determinado trajeto de vida que se constrói a partir de uma lógica teleológica.

O biógrafo (ou, no caso, o jornalista) é mesmo a pessoa mais importante dentro de uma biografia. A escolha dos fatos que farão a "montagem" de uma vida é um importante articulador de sentidos para a significação de um personagem e, consequentemente, através da vinculação de coexistência "pessoa-ato", um importante juiz dos atos que envolvem esta pessoa no presente.

${ }^{48}$ Sobre isso, ver SCHNEIDER, 2006. 


\subsection{O julgamento do ato a partir da quebra do vínculo metonímico:}

Uma vez expostos alguns dos mecanismos básicos que estão em jogo no julgamento do valor de um ato através da evocação de dados biográficos decorridos, nós podemos deslocar um pouco a questão para analisar algumas reportagens que se comportam de um modo um pouco diferente das que foram citadas até este momento. Esse tipo de estratégia argumentativa - ou seja, as vinculações de coexistência pessoaato e o modo de explicação metonímico do relato - são tão comumente usados no jornalismo que, muitas vezes, articulamos determinadas expectativas em torno deles. Esperamos, cada vez que nos é apresentada uma história de vida, que haja uma coerência de ações entre o passado e o presente.

Algumas reportagens, no entanto, subvertem este tipo de expectativa. Em algumas delas, é justamente a quebra do vínculo metonímico que está em jogo nas construções de sentido.

É a partir deste mecanismo que podemos entender como a exposição de um mesmo conjunto de fatos de uma vida pode, dependendo da maneira como se dá a sua inserção, contribuir para a articulação de sentidos completamente diferentes entre si.

Os perfis de Luiz Inácio Lula da Silva no período estudado em nosso corpus mostram isso de uma forma bastante clara. Iremos mostrar a seguir, como alguns deles foram construídos a partir de uma relação metonímica entre o presente e o passado (tal como os exemplos que mostramos até este momento) para, em seguida, mostrar outros em que há a quebra deste funcionamento. Os efeitos de sentido engendrados em um e outro caso são bastante diferentes entre si.

A edição número 547 da revista Carta Capital, lançada no final do mês de Junho, foi uma edição comemorativa do aniversário de 15 anos da revista. Em diversas matérias, era feita uma espécie de avaliação sobre este seu período de existência e sobre as principais mudanças e notícias do mundo neste lapso temporal. Na editoria de política nacional, os textos se concentraram, principalmente, em uma apreciação a respeito dos governos de Fernando Henrique Cardoso e Lula. O tom das reportagens pode ser resumido na seguinte máxima: "sim, o príncipe dos sociólogos foi o grande cabo eleitoral do ex-torneiro mecânico nas eleições de 2002” (CARTA, 27/05/2009: 42). 
Enquanto FHC é descrito de uma forma bem pouco lisonjeira ${ }^{49}$, Lula é posto como um homem que soube vencer as dificuldades - "desde a adolescência, quando a mãe faxineira enterrava os filhos menores até o pescoço no quintal para que não se afastassem da casinhola enquanto trabalhava, Lula fez sua própria sorte" - e como um "líder da brava resistência à ditadura representada pelas greves do ABC de 1978, 79 e 80" (CARTA, 27/05/2009: 42) ${ }^{50}$.

A construção dos dois presidentes como sujeitos antagônicos fica bastante clara no seguinte trecho:

Vem à tona a memória do passado, o $A B C$, o sindicato naquela ladeira íngreme, o Estádio da Vila Euclydes lotado, Lula no palanque. Deitava sua oratória impetuosa, às vezes tropeçava no tempo dos verbos. Recordo também Fernando Henrique, esforçou-se para impedir que Raymundo Faoro subisse ao palanque do presidente do sindicato. Tentativa fracassada, 30 anos atrás (CARTA, 27/05/2009: 45).

Embora outras revistas tenham feito também perfis bastante elogiosos de Lula a revista IstoÉ, por exemplo, neste mesmo mês, publicou "Como Lula driblou o destino", que versava sobre a infância pobre do presidente e o modo como ele conseguiu se estabelecer politicamente - poucas matérias foram tão eloquentes quanto a de Carta Capital. Esta é uma postura que se afirmará não só nesta edição como nas seguintes, ao reforçar, em diversas matérias, a origem humilde e a ascensão do presidente, chamando-o frequentemente de "ex-metalúrgico" - mesmo em matérias que não versavam especificamente sobre sua trajetória de vida.

A reportagem da IstoÉ também esboça uma reportagem bastante favorável a Lula e ao julgamento dos atos que envolvem a sua biografia. Isso por ser percebido logo na linha-fina da matéria que conta que "na infância, ele escapou da mordida de uma jumenta e de ser deixado na estrada na viagem a São Paulo. Na juventude, pegava o

\footnotetext{
${ }^{49}$ FHC é descrito nos seguintes termos: "o ex-presidente é muito popular nas salas Vips dos aeroportos, nos restaurantes da moda de São Paulo e no calçadão da zona sul do Rio de Janeiro. Infelizmente, a massa ignara e comprada pelo Bolsa Família não entende o papel de estadista do sociólogo e principal líder do PSDB. Obama está enganado: FHC é 'o cara' (dizem que uma palestra sua não sai por menos de 50 mil dólares) O FMI teve de socorrer o Brasil três vezes durante o seu mandato? A emenda da reeleição foi um claro atentado às regras democráticas vigentes (isso sem mencionar a compra de votos para a sua aprovação)? Aleivosias de gente atrasada e ignorante que reluta em negar seu papel histórico, inclusive o de cabo eleitoral do torneiro mecânico que, por ora, governa este País" (CARTA CAPITAL, 27/05/2009: 46).

${ }^{50}$ Lula é mesmo descrito como um herói quixotesco nesta reportagem: "não me surpreenderia se ele dissesse nunca ter lido Marx, suponho que um de seus modelos seja Dom Quixote, representado na casa modestíssima do operário dos anos 70 por uma estatueta do herói de Cervantes. Enfeitava uma estante de poucos livros. Aposto, porém, em um Quixote mítico, intérprete do destemor e inconformismo, em lugar do tresloucado cavaleiro fora de seu tempo. Lula mantém os pés no chão e a cabeça na exata atmosfera do presente (CARTA, 27/05/2009: 44).
} 
paletó emprestado de um amigo para ir aos bailes. E ficou três anos deprimido com a morte da primeira mulher" (RODRIGUES, 13/05/2009: 37).

Nas duas reportagens, a narrativa engendrada é bastante favorável a Lula porque apela para um discurso bastante apreciado socialmente que diz respeito à afirmação do self made man, de um homem que conseguiu superar as adversidades e chegar à presidência, quase como uma espécie de jornada do herói. Alguns autores tentam delinear os motivos pelos quais este é um discurso tão estimado e muitos apontam para o fato de que ele realiza, de certa forma, uma espécie de gozo imaginário que é bastante típico da sociedade em que vivemos.

Para Maria Rita Kehl, por exemplo, duas das formas de alienação características da subjetividade moderna podem ser resumidas pela máxima "você decide e Freud explica". Isso significa que, de um lado, viveríamos uma espécie de delírio de autonomia relacionado a um desejo de não ter que prestar contas a respeito de nossos atos e nem ter de lidar com quaisquer consequências que advenham deles. A outra parte estaria relacionada à articulação de uma esperança de que outras instituições ou lugares sociais (como a psicanálise, por exemplo) pudessem dar conta de explicar as motivações inconscientes ou alheias que puderam intervir nestas decisões pessoais, quase como uma forma de desculpar nossos atos. É em torno disso que se articularia o dever de gozo da sociedade atual.

“O sujeito das 'culturas do narcisismo', adaptado às condições desejantes das grandes sociedades de mercado (independente de suas condições materiais), acredita que tem uma espécie de direito natural ao desfrute de todos os bens que a publicidade lhe oferece ou, pior ainda, acredita que tem uma espécie de dever de desfrutar deles" (KEHL, 1996).

É neste contexto que a figura do self made man ocupa um lugar privilegiado dentro do imaginário contemporâneo, uma vez que ele apela para esta possibilidade deste gozo ininterrupto, para a ideia de que todos os desfrutes estão ao alcance da mão e para todos. "É o self-made-man imaginário (como todo self-made-man), que se acredita sem outro compromisso a não ser com o próprio gozo, ao qual a mídia publicitária - ou a mídia em geral, já que toda mídia é pautada pelos imperativos da publicidade - apela incessantemente" (KEHL, 1996).

Trata-se de um tipo de discurso, portanto, cuja significação é bastante valorizada socialmente. Ele está combinado, ainda, com um discurso relacionado à ascensão do vencido que, posta em ação, confere dignidade e prestígio ao relato. Segundo Carolyn Kitch (2005), este é também um assunto bastante comum na imprensa norte-americana 
e as remissões históricas nas revistas deste país também fazem constantes menções a códigos narrativos como estes. "O presidente Jimmy Carter foi retratado em todas as revistas dos anos 70 como o underdog-outsider que restaurou a fé na liderança política na América, enquanto o Papa João Paulo II foi descrito como 'o cavalo negro polonês que conquistou Roma"' (KITCH, 2005: 26).

De fato, as revistas IstoÉ e Carta Capital são as que mais frequentemente se manifestam a favor de Lula e isso é refletido nas narrativas que encontramos sobre a vida do presidente. A expectativa metonímica se estrutura em torno do relato de acordo com o mesmo esquema delineado anteriormente e faz com que o valor positivo atribuído a sua biografia seja transferido para o seu governo ou para o seu modo de governar. É assim que o presente e o passado entram em uma relação de solidariedade.

Não é necessário, no entanto, que se mudem os fatos da biografia para que seja obtido um efeito de sentido diferente, senão oposto. Em contraste com essas duas reportagens, podemos observar perfis sobre Lula publicados em Veja e Época. Nestas duas revistas, os relatos citados efetuam uma quebra da expectativa metonímica.

Na coluna de Ruth de Aquino da edição de 22/06/2009, os fatos destacados da vida do presidente, embora não difiram muito dos apresentados pelas outras revistas possuem uma finalidade bastante diferente. Ela começa por colocar que:

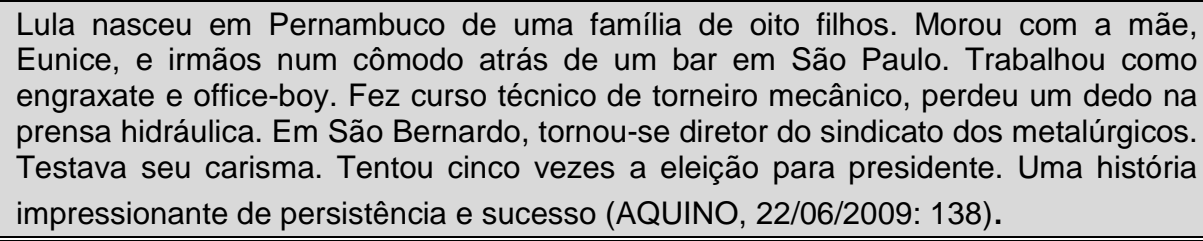

A história de enaltecimento do self made man, no entanto, acaba neste ponto e as verdadeiras intenções do delineamento do perfil ganham forma:

Sempre disse o que pensava. Em 1986 chamou Sarney de 'grileiro do Maranhão'.
Em 1987, chamou Sarney de 'ladrão' - perto dele, Maluf não passaria de 'um
trombadinha'. Em 1993, disse que, 'de todos os deputados do Congresso, pelo
menos 300 deles são picaretas'. Agora, Lula depende da bancada do PMDB, a
maior do Senado. Em terras remotas, no Cazaquistão, defendeu Sarney e o colocou
num pedestal (AQUINO, 22/06/2009: 138).

A colunista acrescenta, ainda, que "Lula é hoje parte da elite que sempre criticou com ferocidade" e que "de vez em quando, Lula incorpora o sindicalista (lá fora) e critica os ricos e poderosos, em surtos de demagogia atabalhoada" (AQUINO, 22/06/2009: 138). 
A estratégia utilizada pela revista Veja também não é muito diferente desta. Ela exalta determinados trechos da biografia do presidente para, em seguida, apontar uma disjunção ou um distanciamento de seus propósitos iniciais. Isso pode ser notado claramente na reportagem “À sombra da constituição", de 24/06/2009. Ao apontar por que o presidente não poderia ter dito que Sarney não deveria ser tratado como uma pessoa comum, a revista apela para a biografia de Lula:

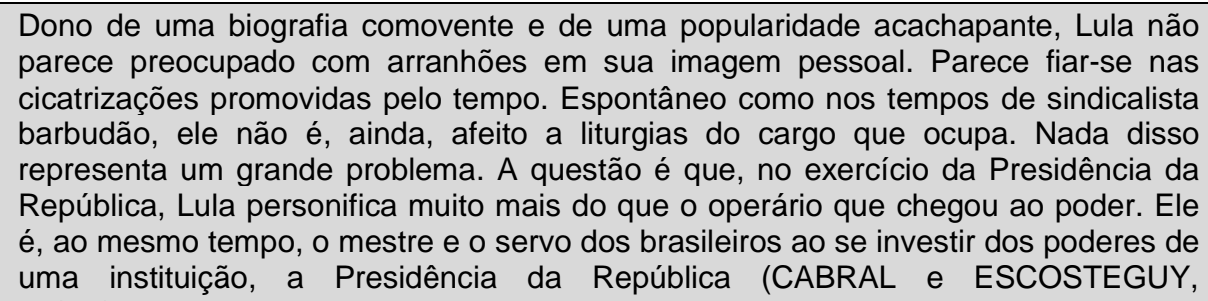
parece preocupado com arranhões em sua imagem pessoal. Parece fiar-se nas cicatrizações promovidas pelo tempo. Espontâneo como nos tempos de sindicalista barbudão, ele não é, ainda, afeito a liturgias do cargo que ocupa. Nada disso representa um grande problema. A questão é que, no exercício da Presidência da República, Lula personifica muito mais do que o operário que chegou ao poder. Ele é, ao mesmo tempo, o mestre e o servo dos brasileiros ao se investir dos poderes de uma instituição, a Presidência da República (CABRAL e ESCOSTEGUY, 24/06/2009: 60).

Para pensarmos nos efeitos de sentido mobilizados por estas duas reportagens, é importante destacar o fato de que o processo metonímico só pode ser posto em ação se ancorado em valores comuns. O seu sucesso - que significa, portanto, o seu reconhecimento - como coloca Faria (1986: 550), "parece depender não só da natureza dos valores, mas também dos mecanismos de aquisição e reprodução a que estão associados (o desejo é metonímico, segundo Lacan); ao resultar da seleção entre relações de contiguidade (associação), a metonímia depende também da manutenção cultural das relações de sentido". É por este mecanismo de transferência de valores inferidos que as reportagens de IstoÉ e Carta Capital funcionam.

Nestas reportagens de Época e Veja há uma diferença fundamental na medida em que há a quebra do mecanismo metonímico. As expectativas articuladas que estão relacionadas ao comportamento de um self made man como Lula são quebradas e os marcadores de pressuposição alocados ("agora Lula depende" ou "personifica muito mais") marcam uma relação de disjunção entre o presente e o passado. Esta ruptura diz respeito ao fato de que, em um primeiro momento, as duas reportagens acionam o movimento metonímico (com o decorrido posto de maneira positiva) apenas com o desejo de romper com ele posteriormente. É impossível a reprodução de um sentido positivo do presente pelo passado exatamente por causa dos eventos da atualidade que são evocados, marcando, assim, uma disjunção radical.

As duas narrativas se esforçam para estabelecer, portanto, uma recusa de ligação entre o passado e o presente e construir um mecanismo, como posto por Perelman e Olbrechts-Tyteca (1996: 467) que coloca que uma construção que era tida como 
normalmente aceita (presumida ou mesmo desejada) não tem validade "porque nada permite constatar ou justificar a influência que certos fenômenos examinados teriam sobre aqueles que estão em causa e porque, em consequência, é irrelevante levar-se em consideração os primeiros”. O jogo, aqui, está em afirmar, justamente, que dois elementos são indevidamente associados, não possuindo uma relação que se justifique e, portanto, que devem permanecer independentes.

É justamente a relação entre o par "aparência-realidade" que está em jogo nestas matérias e que, segundo Perelman e Olbrechts-Tyteca constituem um caso privilegiado e prototípico de todas as questões que promovem uma disjunção entre conceitos. Os subentendidos das matérias estão postos justamente aí, aonde a aparente exemplaridade que a trajetória pessoal da vida de Lula sugere é desarticulada em virtude de uma suposta realidade de seu governo, vinculada a manobras políticas pouco desejáveis.

A aparência ${ }^{51}$, relacionada àquilo que é conhecido diretamente, dentro deste mecanismo, só pode ser compreendida se posta em relação com a suposta realidade apresentada. É ela que fornece o critério para distinguir o que é válido ou o que não passa de mera aparência. Desta forma, é importante notar que esta realidade sugerida não se configura como um mero dado, mas sim, como uma construção que hierarquiza quais aspectos devem ser qualificados como "merecedores de atenção" e quais são tidos como "enganadores" ou "ilusórios". Estes segundos são todos aqueles que não estão conformes a esta regra posta por esta construção do real.

É por este mecanismo que avaliamos a biografia de Lula quando ela está em relação com algumas das alianças de seu governo. É o contato e a defesa de Sarney que permite a distinção de que sua biografia não representa nada além de uma mera aparência (ou, na pior das hipóteses, um engodo). As regras postas pela construção do real sugerida nas reportagens incompatibilizam a ideia de que a biografia de Lula seja uma expressão verdadeira do que se esperava para seu governo. Os subentendidos estão aqui articulados, portanto, como uma suposta traição às origens que as transformam, no final das contas, em puro material eleitoreiro.

A construção deste efeito de sentido também foi explorada em outras matérias. As quatro revistas analisadas, por exemplo, denunciaram a aproximação de Lula com o

\footnotetext{
${ }^{51}$ Como bem explicam Perelman e Olbrechts-Tyteca (1996: 472), "é possível que a aparência seja conforme ao objeto, confunda-se com ele, mas é possível também que ela nos induza ao erro a seu respeito. Enquanto não tivermos razão alguma de duvidar dela, a aparência é apenas o aspecto sob o qual o objeto se apresenta, entende-se, por aparência, a manifestação do real. Apenas quando as aparências, por serem incompatíveis, não podem ser aceitas todas ao mesmo tempo, é que se opera, graças à distinção entre as aparências que são enganosas e as que não o são, uma dissociação que dá origem ao par 'aparência-realidade', do qual cada termo remete ao outro".
} 
ex-presidente Fernando Collor justamente a partir de elementos biográficos dos dois políticos, enfatizando a disjunção entre o par "aparência-realidade".

Para Veja, "Lula está com Fernando Collor e não abre. Para seu passado e para as pessoas que o seguiram com admiração na gloriosa trajetória da liderança sindical até o posto mais alto da hierarquia política do país, a Presidência da República, ele manda "aquele abraço"” (CABRAL, 22/07/2009: 65). Já Ruth de Aquino, em sua coluna da revista Época (20/07/2009: 138), lembra que "Collor já tinha envergonhado a nação em 1989, na campanha para a Presidência, ao aplicar golpe baixo no adversário do PT, Luiz Inácio Lula da Silva. Exibira na televisão o depoimento de Miriam Cordeiro, exnamorada de Lula, acusando-o de pressão para abortar a filha dos dois". Depois de aludir a um discurso que Lula fez em 1994, quando Collor havia sido absolvido pelo STF - onde ele dizia que "como cidadão brasileiro que tanto luta para fazer a ética prevalecer na política, estou frustrado, possivelmente como milhões de brasileiros. Só espero que não apareça um trambiqueiro querendo anistiar Collor da condenação imposta pelo Senado" -, Aquino comenta que agora "a palavra ética 'sumiu' do discurso de Lula".

Também Attuch, em IstoÉ (22/07/2009: 43), coloca que os dois "não eram mais os adversários de 1989, ano em que Collor venceu a disputa presidencial com golpes abaixo da cintura (...). Por pouco não se ouviu um hino aos descamisados e um grito de caça aos marajás. Não se sabe se foi Lula quem 'colloriu' ou se foi Collor quem aderiu ao lulismo, mas não importa". E assim, o comentarista coloca que "conciliar é da tradição brasileira. Mas não deixa de ser estranho notar que os dois antípodas de 1989, que pareciam tão distantes, possam andar de mãos dadas 20 anos depois”.

Carta Capital também alude a este efeito de sentido que remete à disjunção entre o par "aparência-realidade", mas o seu foco é outro. Segundo ela,

Não é que o episódio vá abrilhantar o currículo do presidente Lula. Longe disso. Mas cabe uma pergunta aos jornais, revistas e emissoras de tevê que trataram como escandalosa a confraternização do petista com o neoaliado Fernando Collor de Mello: quem foi mesmo que, em 1989, se valeu de todo e qualquer expediente, inclusive o da edição farsesca de um debate televisivo, para eleger o 'Caçador de Marajás' contra o 'Sapo Barbudo'? (CARTA CAPITAL, 29/07/2009: 17).

Neste trecho, a revista ironiza o comportamento da própria imprensa que, ao apontar à disjunção do par "aparência-realidade" no comportamento de Lula, parece não perceber as incoerências de seus próprios atos. Os efeitos de sentido mobilizados nesta matéria são bem similares às matérias anteriores. Um suposto antagonismo no passado é colocado do lado das "aparências" enquanto o restante da matéria se esforça em mostrar qual é a "realidade". 
Se aplicado ao esquema proposto por Ducrot, os efeitos de sentido mobilizados pelos textos que citamos, podem ser representados no seguinte diagrama:

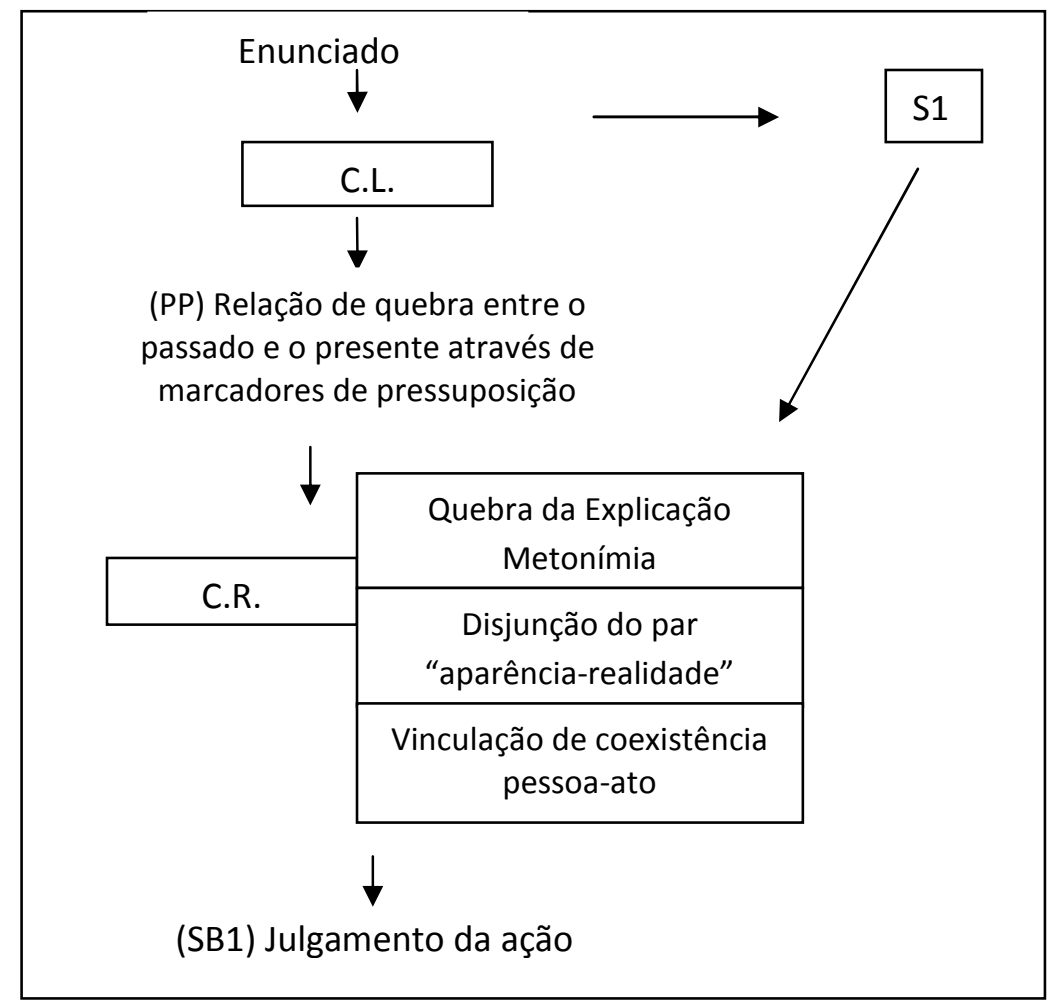

Há algumas situações nas narrativas jornalísticas, portanto, em que o efeito de sentido é articulado não propriamente pela força da explicação metonímica do relato, mas sim, justamente a partir de sua desarticulação. É esta perturbação na relação entre o passado e o presente que cria os efeitos de sentido relacionados à disjunção do par "aparência-realidade". E, contrariamente ao que vinha sendo mostrado nos exemplos anteriores, não é mais o passado que funciona como uma chave de leitura para o presente; é a atualidade que fornece os moldes necessários para a atribuição de valor ao decorrido.

Por fim, ainda precisamos analisar uma última forma em que o material histórico de cunho biográfico aparece no jornalismo. Trata-se das biografias modais.

\section{O Jornalismo e as Biografias Modais:}

Por "biografia modal", Giovanni Levi se refere a determinados arranjos biográficos que, embora retratem a vida de uma única pessoa, guardam um objetivo mais ambicioso, referente ao retrato de um agrupamento social ou de uma forma típica de comportamento. "A biografia não é, neste caso, a de uma pessoa singular e sim a de 
um indivíduo que concentra todas as características de um grupo" (LEVI, 1998: 175). É bastante comum encontrarmos também este tipo de abordagem biográfica no jornalismo.

É o caso, por exemplo, da matéria "Crime Universitário" publicada pela revista IstoÉ, em 18/02/2009. O texto noticia alguns casos de violência durante as atividades lúdicas feitas normalmente na primeira semana de aula nas universidades e defende o fim dos trotes. Mesmo que os casos recentes de abuso pudessem já assegurar uma argumentação eficiente para o posicionamento revista, não obstante, ela monta um box mostrando a "história de agressões graves e até mortes que marcam os trotes há anos".

Muito embora os casos de agressões recentes não envolvessem nenhuma morte, a sua possibilidade é aludida através desta remissão ao passado. Ela cita, por exemplo, que, em março de 1980, "Carlos Alberto de Souza, calouro da Universidade de Mogi das Cruzes (SP) morreu devido a socos na cabeça. Ele reagiu quando os veteranos tentavam cortar seu cabelo à força". Ou ainda que, em Março de 1990, "o calouro de direito George Araguaia Parreira Mattos teve uma parada cardíaca e morreu ao tentar fugir de trote em Rio Verde (Goiás)"; e, em Abril de 1992, "o estudante de economia Alexandre Vasconcelos é expulso da PUC de Campinas por praticar trote violento contra José Ricardo Ribeiro, que sofreu fratura na mandíbula e amnésia" (LOES e FRUTOSO, 18/02/2009: 62-63).

Neste tipo de uso de uma sequência narrativa de trajetórias pessoais, o importante não é tanto a vida do indivíduo ou o modo como ele morreu, mas sim, as circunstâncias que circundam sua morte, pois são elas que enquadram este sujeito dentro de um determinado grupo social: daqueles que sofreram consequências pesadas em função dos trotes nas universidades e devem, por este motivo, servirem como exemplo. O importante não é tanto o sujeito, mas sim, a situação em que ele está envolvido. Remissões como estas dão um toque humanitário para um problema abstrato.

Muito embora seu uso seja bastante frequente, não só sujeitos anônimos figuram em biografias modais. Na reportagem da Época "A nova onda dos remédios para o cérebro" (sobre o aumento do uso de medicamentos indicados para problemas como déficit de atenção por pessoas normais que os usam como estimulantes), por exemplo, é colocado um quadro intitulado "As drogas dos gênios". Nele, a revista tenta mostrar que "recorrer a químicas para turbinar a mente não é um recurso novo" e, para isso, faz remissão a "alguns dos pensadores mais proeminentes de nossa história e às substâncias que eles empregaram" (VERA, 11/05/2009: 68). 
Cita, então, pensadores como Francis Bacon ("além de fumar cachimbo, o filósofo político e escritor costumava usar o tempero de açafrão para estimular o cérebro"), Honoré de Balzac ("o café era usado pelo escritor francês para dedicar até 16 horas seguidas ao trabalho"), Jean Paul Sartre ("o filósofo francês fumava dois maços de cigarro por dia, quando não os trocava por charutos ou pelo cachimbo") e Charles Baudelaire (que "usava ópio, éter e haxixe para aliviar as dores da sífilis, doença que contraiu ainda jovem") (VERA, 11/05/2009: 68-69).

Nem sempre os retratados, no entanto, precisam ser apresentados em conjunto para se tratar de uma biografia modal. Um bom exemplo a respeito disso é a reportagem "Calote oficial", publicada na revista IstoÉ, de 17/06/2009. O texto versava sobre a dificuldade dos contribuintes em receber os precatórios do governo e contava a história de Duzolina Martins, uma viúva que “orgulha-se de nunca ter deixado de pagar nem uma conta sequer. Em agosto, ela vai fazer 80 anos e há pelo menos 16 espera que o governo do Estado de São Paulo faça o mesmo e quite a dívida em precatório alimentar que tem com ela". Segundo a reportagem, "dona-de-casa, Duzolina entrou com uma ação em 1993 para receber a pensão do marido morto em 1985 e ganhou" embora não tenha recebido nada até agora (PATI e MARQUES, 17/06/2009: 48).

Nestas reportagens, há também um modo de explicação metonímico do relato, uma vez que estas biografias pontuais funcionam como representantes de outras pessoas possivelmente afetadas por situações similares. Dentro de uma lógica jornalística, essas inserções funcionam como modos de humanizar o narrado, retirando-o de uma esfera puramente abstrata e recorrendo a alguns elementos de cunho emocional.

Sua inserção mobiliza alguns efeitos de sentido interessante uma vez que, de acordo com Angrimani (1995: 17) favorece o estabelecimento de uma identificação entre o leitor imaginado e a vítima: "a humanização do relato faz com que o leitor reviva o acontecimento como se fosse ele o próprio autor do que está sendo narrado". Também Sodré e Ferrari (1986: 15) insistem neste ponto quando afirmam que "nas condições de sofrimento de um indivíduo, filtradas pelas impressões de um outro indivíduo", projetam-se mesmo problemáticas de caráter maior, como "as dificuldades de uma nação em luta pela vida”. E é por isso que ela está diretamente vinculada a traços emotivos.

O uso de uma biografia modal, de acordo com Levi, implica uma busca por formas típicas de comportamento, de forma que o indivíduo possa servir como ilustração para um coletivo, que possa esboçar as feições representativas de um grupo. 
A forma como este grupo é delineado, contudo, não deixa de ser portador de alguns conjuntos de discursos.

Na reportagem da revista Época sobre o uso de drogas para melhorar as funções cerebrais utilizadas por pessoas sem problemas mentais - procedimento este colocado de forma positiva pela revista - é endossado pelo grupo de pessoas ilustres que ela elege na construção da biografia modal. Os intelectuais evocados conferem dignidade à prática. Também na reportagem da revista IstoÉ sobre a dona de casa Duzolina, esboçase, de certa forma, o grupo típico ao qual pertencem as pessoas que não recebem os precatórios devidos do governo e, assim, delineia-se um tipo de significação específica posta naquela narrativa.

A biografia modal é uma forma de assumir, para Levi, o que Bourdieu coloca nos seguintes termos: que "o estilo pessoal não é nunca mais do que o estilo de uma época ou de uma classe" (apud LEVI, 1998: 177). É, portanto, pelo reconhecimento de se pertencer a um determinado grupo que as biografias modais são articuladas.

\section{Sobre as sequências e funções narrativas de trajetórias pessoais e o estatuto do personagem no jornalismo}

Tratar da problemática da utilização do passado na construção das estórias de vida nas narrativas jornalísticas implica ter que lidar com a questão sobre a construção de personagens feita por este tipo de tecido textual. Alguns estudos sobre esta temática em artefatos literários nos dão algumas pistas interessantes neste sentido.

Phillipe Hamon (1976: 90-91) chama a atenção para o fato de que a personagem nunca aparece em um único golpe nas narrativas literárias: ela surge como um morfema vazio que vai definindo seu sentido progressivamente. “A determinação da 'informação' da personagem, representada na cena do texto pelo nome próprio e seus substitutos, fazse em geral progressivamente. A primeira aparição de um nome próprio (não-histórico) introduz no texto uma espécie de 'branco' semântico: quem é este 'eu' que toma a palavra?".

No jornalismo, encontramos algumas situações em que isso pode ser claramente observado e outras em que o mecanismo é um tanto diferente. De fato, muitos perfis ou entrevistas tem como personagens principais pessoas anônimas ou desconhecidas do grande público e, de uma forma geral, elas instauram mesmo este "morfema vazio" que é descoberto aos poucos, a medida que o texto se desenrola e a personagem nos é apresentada. Em outras, no entanto, a personagem já é pública e os fatos de sua vida são de conhecimento geral. Neste caso, já existem algumas direções de sentido dadas 
previamente e, consequentemente, a personagem já carrega uma série de atributos e expectativas antes que os espaços vazios deste morfema comecem a ser preenchidos pela narrativa jornalística.

O problema esta justamente aí: ainda existem espaços vazios. Com os exemplos mostrados anteriormente, procuramos desvelar como, mesmo quando se trata de personalidades públicas, o modo de se contar sua vida pode ser bastante diferente a partir do tipo de urdidura de enredo que a reportagem coloca. Assim, uma personagem como Sarney pode ser descrita tanto como "ex-presidente da República” quanto como "apoiador do regime militar", sem que nenhuma destas duas informações seja falsa ou necessária em uma reportagem. Escolher uma ou outra (ou as duas) depende quase sempre do tipo de estória que se conta e do tipo de discurso que se quer respaldar.

Isso diz respeito, mais especificamente, a construção desta ilusão biográfica descrita por Bourdieu, a partir da imposição de certa ordem e coerência discursiva para vidas que são frequentemente contraditórias e heterogêneas (mesmo que dificilmente elas nos sejam apresentadas desta forma). Mostrar determinados detalhes significativos da vida de pessoas conhecidas (em detrimento de outras relações possíveis) é um modo de dar ao texto uma determinada direção.

$\mathrm{O}$ que queremos dizer com isso, portanto, é que, assim como na literatura, a construção da personagem na reportagem jornalística também sempre implica a existência destes brancos semânticos em diferentes níveis - seja com personalidades conhecidas ou não. E mais do que isso. O que gostaremos de estudar em seguida é a forma como os dados históricos representados a partir de funções e sequências narrativas de trajetórias pessoais ajudam a completá-los.

Diante dessa indefinição que é própria ao estatuto do personagem, Hamon propõe que ela pode ser estudada tal como um signo. E isso significa assumir que a sua significação não está definida tanto a partir das repetições e acumulações arroladas ao longo da narrativa, quanto a partir das diferenças que são estabelecidas entre ela e os demais signos do mesmo nível. "É, pois, diferencialmente, diante das outras personagens do enunciado que antes de tudo se definirá uma personagem (...). O que diferencia uma personagem P1 de uma personagem P2 é o seu modo de relação com as outras personagens da obra, isto é, um jogo de semelhanças ou diferenças semânticas" (HAMON, 1976: 91) $)^{52}$.

\footnotetext{
$52 \mathrm{O}$ estudo de Hamon se concentra na construção de personagens literárias. Não obstante isso, o próprio autor afirma que este é um esquema que pode ser estendido para diversos outros campos que também lidam com este problema da personagem. Segundo suas próprias palavras: "É preciso não esquecer que esta noção de personagem não é uma noção exclusivamente literária (...) e não está ligada a um sistema
} 
Isso implica que assim como as palavras se definem pelos morfemas que as compõem, bem como pela ordenação e pelo lugar que elas ocupam no sintagma, um personagem também será definido pelo seu modo de relação com os demais personagens ou com as demais partes que compõem o texto.

Nas narrativas jornalísticas, essas relações podem ser alinhavadas de diversas formas (como a relação de um personagem com os demais e com as diversas partes que formam o contexto exposto). Os dados históricos - no caso, o nosso objeto de estudo aparecem como um dos elementos que contribuem para o estabelecimento destes jogos de oposição e solidariedade que marcam o lugar que uma determinada personagem assume no contexto global da estória. A relação entre o passado e o presente biográfico ajuda a delimitar o papel daquele personagem dentro do que está sendo contado e engendra, assim, determinadas valorações ligadas ao julgamento de uma determinada ação ou de um determinado testemunho, por exemplo.

A partir desta lógica, um personagem não é definido em uma narrativa jornalística apenas pela posição que ele ocupa no presente - ou no momento em que se desenrola a estória que está sendo contada. A definição de sua participação será posta também pela relação estabelecida entre seu posicionamento presente e os seus atos do passado (a posição em que ele se encontrava anteriormente).

O julgamento da ação ou da fala, bem como o grupo que ele representa (no caso das biografias modais) se estabelecerá a partir deste jogo de relações. Assim, para o julgamento de algumas falas de Tarso Genro, por exemplo, não foi suficiente explicitar sua posição atual como ministro da Justiça. Passagens de sua vida no passado, como o fato de ter sido militante de esquerda, contribuíram sobremaneira para o julgamento. Elas ajudaram a preencher o vazio semântico aludido anteriormente e estabeleceram um jogo de tensões, relações e oposições em relação a diversas partes do texto.

Outra noção importante trazida por Hamon em sua homologia entre o signo e o personagem diz respeito à noção de que "o signo linguístico define-se pelo seu arbitrário; mas o grau de arbitrariedade de um signo pode ser variável, na própria língua e em outros sistemas semiológicos". Em relação à personagem, isso tem como implicação o fato de que há diferentes graus em que um autor pode motivar determinadas significações em torno dos caracteres que ele representa: "podemos deparar com esta noção se examinarmos a relação que existe entre o nome de uma personagem (o seu significante: nomes próprios, comuns e substitutos diversos que lhe

semiótico exclusivo: o mimo, o teatro, o filme, o ritual, a banda desenhada, empregam "personagens"” (HAMON, 1976: 80). 
servem de suporte descontínuo) e a soma de informação para a qual ele aponta (o seu significado)" (HAMON, 1976: 99) ${ }^{53}$.

É justamente com estes diferentes graus de motivação que a vinculação de coexistência "pessoa-ato" construída a partir de dados históricos trabalha o tempo todo nas narrativas jornalísticas. A apresentação de determinadas características do personagem não precisam ser explicadas quando se diz que uma pessoa foi "exguerrilheira" ou que foi "colaboradora do regime militar". Assim como chamar alguém de "Madame" na ficção pode motivar uma série de significações, como exposto por Hamon; o uso do passado no jornalismo, com suas informações pretensamente objetivas, costuram também alguns sentidos bastante específicos a partir de códigos estereotipados.

Por fim, uma outra homologia bastante profícua está na asserção de que "todo o enunciado se caracteriza pela redundância das marcas gramaticais" (HAMON, 1976: 100). Da mesma forma, a significação do personagem também terá o auxílio destas marcas que contribuirão para acentuar a redundância das ações cometidas e, de uma maneira geral, a previsibilidade da narrativa. Com isso, contribuirão as descrições físicas do personagem, bem como o ambiente no qual ele está instalado; os demais elementos com os quais ele se relaciona; a referência a estórias já conhecidas; as ações não funcionais; entre outros elementos que, embora redundantes, são fundamentais para o preenchimento deste vazio semântico inicial característico da personagem.

E assim também trabalham os dados históricos relacionados às estórias de vida inseridas nas construções de reportagens. Sua evocação pode parecer, por vezes, redundante nas matérias, pois, muitas vezes, não acrescentam significações novas além das que já estavam postas nos textos: nós já podemos enxergar ou reconhecer determinados personagens como mau-caráter ou como heróis mesmo sem informações detalhadas de seu passado, por exemplo. Essa aparente repetição (ou estes "detalhes insignificantes”), no entanto, possuem uma lógica bastante precisa se o considerarmos sob o ponto de vista de fixação da redundância e do aumento do efeito expressivo da

\footnotetext{
${ }^{53}$ Esta motivação pode alcançar diversos níveis como, por exemplo, dimensões visuais (como o I para indicar magreza e o $\mathrm{O}$ como seu contrário) e acústicas (como as onomatopeias). E assim, "o artigo (La Berma), a partícula (M. de... / Mme. de...), o título (o conde de...), a duplicação expressiva (Tintin / Totó), certos nomes (Phillippe, Anne...) ou apelidos (M. de Saint-N...) culturalmente valorizados funcionam como morfemas com o sentido fixo que remetem para este ou aquele conteúdo estereotipado (a nobreza de espírito, a familiaridade, a baixeza, etc.). (...) O instinto etimológico e a analogia estão na base disto, e quanto mais o relato é dirigido a um público vasto e heterogêneo, tanto mais estas diversas tendências serão utilizadas, pois é preciso assegurar a comunicação fazendo referência ao maior número possível de códigos estereotipados" (HAMON, 1976: 100).
} 
significação. Elas contribuem, ademais, para o estabelecimento de um efeito de real em torno do que é contado.

Como colocamos anteriormente, a vinculação pessoa-ato depende de uma sobredeterminação complexa entre o valor que atribuímos ao ato e a apreciação que temos sobre a natureza da pessoa. Ela é, portanto, um componente retórico que contribui na formação de determinados julgamentos de valor. Ao utilizar dados históricos na composição desta vinculação (ou, em outras palavras, no preenchimento deste vazio semântico no personagem), no entanto, as informações objetivas contidas ali parecem amenizar este efeito de sentido, em direção a uma informação mais "acreditada".

E é por estas razões postas que podemos pensar que, de um modo geral, ao evocar a história, essas reportagens citadas invocam, em verdade, um posicionamento para os personagens dentro de uma estória. 


\section{CAPÍTULO IV \\ COMPARAÇÕES E DISJUNÇÕES ENTRE O ATUAL E O DECORRIDO: AS CONSEQUÊNCIAS, AS FINALIDADES E AS ANALOGIAS}

O fato de que a linguagem é formada a partir de relações opositivas já é uma ideia tão consolidada que talvez não sejam necessárias maiores explanações acerca deste tema. Uma das explicações mais belas, neste sentido, possivelmente, seja a de Ducrot (2009: 11) quando ele coloca que "a oposição, para Saussure, é constitutiva do signo da mesma forma que a alteridade é, para Platão, constitutiva das ideias. O valor de uma palavra - ou seja, sua realidade linguística - é o que a opõe às outras. Indo mais longe, é a de se opor às outras. Seu ser é ser outro". E assim, "todas as vezes que tentamos atribuir-lhe uma característica positiva, escondemos sua verdadeira natureza, traição talvez inevitável - porque, afinal, se falamos, é certamente para 'dizer alguma coisa' - mas que continua sendo uma traição".

O que Ducrot relembra, neste texto, é a explicação de Platão a respeito das categorias fundamentais da realidade (segundo ele, o Movimento, o Repouso, o Mesmo e o Ser). Elas não se diferenciariam entre si por algum tipo de característica intrínseca ou valor positivo que pode ser percebido quando avaliamos essas categorias isoladamente. Elas são distintas por causa da forma em que participam de uma quinta categoria, o Outro. Assim, o Movimento não é Movimento por algo que ele possua ou por algo que possa ser percebido nele em si; ele só é Movimento porque é outro, diferente do Repouso e do Mesmo e do Ser.

É a partir disso que Ducrot (2009: 11) pode afirmar que "ora, outrem ou não é nada, ou é este outro constitutivo de que fala Platão, este outro que me constitui a mim mesmo, porque é somente através dele que posso me ver e é através de seu reconhecimento que posso me reconhecer". E é por isso que "se outrem tem esta função constitutiva do Outro platoniano, e se a língua é, antes de mais nada, o terreno onde afronto outrem, não nos surpreenderemos com o fato de a língua ser, como viu Saussure, fundamentalmente opositiva".

Esta relação com o outro tem implicações importantes. Ducrot (2009: 12) chama a atenção para o fato de que "se falar é, antes de mais nada, constituir seu próprio pensamento obrigando outrem a nos enviar dele um reflexo, e se a língua tem por função primordial permitir este jogo de fala, o enunciado (tomado aqui como o protótipo da entidade linguística) não é mais nada em si mesmo, não é senão a alusão a outros enunciados". 
A percepção temporal também não difere deste funcionamento calcado em relações opositivas: o presente se constitui como presente a partir de seu outro, o passado (ou o futuro), em uma relação que é calcada tanto na diferenciação dos tempos quanto nas suas formações.

As funções e sequências narrativas de ordem comparativa e as de disjunção nos oferecem esta oportunidade de revisitar essa relação opositiva entre o presente e o passado e estudar a forma como isso é materializado em alguns tipos de construções textuais. O objetivo deste capítulo é justamente estudar os textos jornalísticos nos quais o atual e o decorrido são postos lado a lado (seja através de uma relação de solidariedade, seja de ruptura) e, a partir disso, esmiuçar quais são os efeitos de sentido resultantes desta construção.

A remissão a eventos decorridos a partir de uma relação de comparação dentro das narrativas jornalísticas também parece comportar esta dimensão de remissão a enunciados outros. São justamente os confrontos entre passado e presente que remetem a este "futuro discursivo que projeta diante de si esta sombra de si mesmo que é a sua única realidade" (DUCROT, 2009: 12) uma das pistas que iremos seguir para estudarmos a problemática da inserção dos dados históricos no jornalismo.

As funções e sequências narrativas de ordem comparativa, conforme já havíamos colocado, são caracterizadas por apresentar um vínculo de solidariedade entre o presente e o passado, que pode ser posto tanto a partir de uma comparação direta (exemplos, analogias e metáforas) quanto por meio de uma ligação de sucessão entre causas e/ou consequências similares. Assim, elas podem dizer respeito tanto ao relacionamento de dois acontecimentos por meio de uma comparação direta; quanto à correlação de dois acontecimentos por meio de um mesmo vínculo causal; ou, ainda, à correlação de dois acontecimentos a partir de um mesmo conjunto de consequências ou de efeitos. (PERELMAN E OLBRECHTS-TYTECA, 1996: 299-300):

Tendo isso como base, podemos delinear, ainda, uma outra forma de apresentação dos fatos em que as funções e sequências narrativas se desenham de um modo oposto. Neste outro pólo, estão as funções narrativas de disjunção, ou seja, aquelas nas quais o passado e o presente são tidos como dessemelhantes e suas respectivas situações são postas com causas e consequências diferentes entre si. Da mesma forma que a categoria anterior, ela possui algumas variações como, por exemplo, o relacionamento de dois eventos por meio de uma ruptura importante que os separa ou a correlação de dois acontecimentos por meio de um rompimento de vínculo causal ou consequêncial. 
Depois de analisarmos as reportagens, procuraremos mostrar, a partir de Vogt (2009), como as relações de comparação entre o atual e o decorrido, essencialmente argumentativas, estão situadas em um intervalo semântico que não se encontra entre os objetos comparados, mas na orientação que é dada à apreciação do interlocutor em relação a eles. Assim, confrontados textualmente, os dois tempos participam desta relação opositiva que, comparados, acabam por constituir o evento relatado. E assim, a partir da evocação à História, o jornalismo acaba invocando uma determinada imagem do presente.

Existem diversos modos - refletidos em diferentes formas de construções narrativas e argumentativas - a partir dos quais o jornalismo efetua uma comparação entre o atual e o decorrido. Nos próximos tópicos tentaremos esmiuçar como eles se articulam.

\section{O peso das consequências: comparação histórica e argumento pragmático}

Muitas das sequências nas narrativas jornalísticas que comparam o passado e o presente através de uma relação de solidariedade entre as duas temporalidades são construídas a partir de uma suposta similitude de causas que podem levar a um mesmo conjunto de consequências. Assim, o evento ligado ao passado é construído textualmente de uma maneira que as causas apontadas para o seu surgimento sejam as mesmas de um acontecimento do presente que está sendo noticiado. A partir disso, os resultados ou efeitos prováveis também se tornam os mesmos (na medida em que as causas são as mesmas). E isso tem importantes implicações nas construções de sentido de um texto.

Isso porque o julgamento a respeito do valor simbólico de um acontecimento é, muitas vezes, aludido a partir da significação de suas consequências. É a isso que se costuma chamar de argumento pragmático e que, segundo Perelman e Olbrechts-Tyteca (1996: 303), “desempenha um papel a tal ponto essencial na argumentação que certos autores quiseram ver nele o esquema único da lógica dos juízos de valor. Para apreciar um acontecimento, basta reportar-se a seus efeitos". Seu mecanismo é engendrado a partir de uma espécie de transferência do valor das consequências para as causas, permitindo apreciar uma situação segundo seus resultados ou efeitos presentes ou futuros.

Como ele está fundado (e esta é uma das condições para a sua existência) a partir de um acordo social sobre quais são os valores das consequências postas, esta transferência é feita de uma forma bastante automática. Segundo Perelman e Olbrechts- 
Tyteca (1996: 304), está relação é por vezes bastante emocional e acaba fazendo remetência às características essencialistas de um determinado objeto: "a ligação entre uma causa e suas consequências pode ser percebida com tanta acuidade que uma transferência emotiva imediata, não explicitada, opera-se destas para aquelas, de tal modo que se acredita prezar alguma coisa por seu valor próprio, ao passo que são as consequências que, na realidade, importam".

E é por isso que ela não requer, de uma maneira geral, de muita justificação para ser aceita. É justamente o posicionamento oposto que, normalmente, irá precisar ser defendido a partir de uma argumentação.

Como é muito difícil determinar e reunir todas as causas de um evento, o argumento pragmático necessita de um esforço, com o objetivo de que a transferência de valor se opere claramente, em mostrar que certo evento é condição necessária e suficiente de outro. Assim, "para poder transportar para ele todo o peso do efeito, será preciso diminuir a importância e a influência das causas complementares, considerandoas ocasiões, pretextos, causas aparentes" (PERELMAN e OLBRECHTS-TYTECA, 1996: 306).

A avaliação das consequências de um evento do passado posto como similar a um acontecimento do presente é um dos usos do argumento pragmático que pode ser bastante comumente encontrado nas revistas analisadas. A apreciação das consequências do decorrido funciona como uma forma de alinhavar uma previsão dos efeitos que ainda estão por vir nos eventos do tempo presente, caso as condições continuem similares, engendrando, assim, alguns juízos de valor a respeito do noticiado. As reportagens sobre a crise econômica mundial estão repletas de exemplos neste sentido.

Ao avaliar a atuação do governo de Barack Obama para o controle da crise através da injeção de dinheiro nos bancos com ativos podres, a revista Veja faz o seguinte alerta retrospectivo:

Exemplos de países que se meteram em enrascadas semelhantes ensinam que,
sem sanear os bancos, não se vislumbra uma recuperação econômica duradoura.
Basta olhar para o Japão, o grande fantasma que paira sobre os Estados Unidos.
Depois do estouro de sua bolha, no fim dos anos 80 , os japoneses injetaram trilhões
de ienes na economia, mas procrastinaram por uma década o saneamento dos
bancos: o país fez obras desnecessárias, endividou-se cada vez mais, e ainda assim
não emergiu da letargia - justamente porque os bancos permaneceram insolventes
(GUANDALINI, 18/02/2009: 72).

A partir de uma pressuposição de que a situação dos Estados Unidos atualmente seja similar a vivida pelo Japão no fim dos anos 80 - e aqui, podemos claramente ver 
marcadores de pressuposição como "basta olhar" e "ensinam" - constrói-se uma apreciação a respeito do pacote proposto por Obama. É através, portanto, de uma associação entre os efeitos desastrosos da crise japonesa e as possíveis consequências de um descuido dos EUA com relação a seus bancos que a revista desqualifica os argumentos dos que se pronunciaram contrariamente à injeção de dinheiro nas instituições bancárias. Não são apresentados no restante da reportagem outros argumentos que justifiquem por que esta escolha de Obama poderia ser a melhor em comparação a outras. O uso da história é a sustentação suficiente para esta apreciação.

É justamente o julgamento de uma ação presente a partir das consequências de uma situação tida como similar no passado que se configura como o mecanismo básico das lições da história, sustentada a partir de uma espécie de antevisão para o futuro. Este exercício de futurismo se aproxima bastante daquilo que Hobsbawm, conforme já havíamos aludido, chama de "uso antiquado" ou "experiencial" da história: ou seja, uma remissão ao passado que o toma o decorrido como similar ao presente e como uma espécie de depósito de conhecimentos. A referência ao caso japonês, mais do que uma mera referência histórica, engendra mesmo subentendidos relacionados às maneiras corretas de ação a partir de um conjunto de saberes já dado. Não é por acaso que a revista apresenta o precedente como um ensinamento.

Mais do que isso, a reportagem também engendra algumas perspectivas para o futuro de modo que a História possa ajudar a delinear algumas conjunturas possíveis. Esse mecanismo fica ainda mais claro em algumas outras matérias, como mostraremos a seguir. As maneiras pelas quais o passado pode legitimar o presente são, no entanto, bastante vastas e podem ser acionadas mesmo quando o passado parece dessemelhante ao presente.

Também sobre a crise, a revista Época - ao comentar que muitos países, embora condenem o protecionismo e alertem para o perigo da desglobalização, adotam medidas contrárias ao aumento do comércio global - afirma que "não é apenas o futuro que provoca inquietação. Também o passado traz sustos“. Ela faz uma alusão a um acontecimento relacionado às ações protecionistas de Willis Hawley e Reed Smoot:

Em 1930, os dois foram responsáveis por uma lei que aumentou a tarifa de importação de 20 mil produtos a níveis recordes nos Estados Unidos. A retaliação veio rapidamente - e o resultado é que as exportações americanas caíram pela metade. O comércio internacional murchou. Para muitos estudiosos, o espetacular cerco às importações americanas assinado pela dupla Hawley e Smoot, deu uma contribuição milionária para a depressão econômica mundial dos anos 30 - que, ente outros efeitos, facilitou a ascensão de Adolf Hitler na Alemanha. Os acordos que vigoram hoje protegem o mundo de ações como a de Hawley e Smoot (NOGUEIRA, 09/02/2009: 74). 
Estes acordos aludidos na última frase são explicados em parágrafos anteriores e se referem, basicamente, a medidas como as tomadas, por exemplo, na administração de Margaret Thatcher e que diminuíram drasticamente a intervenção do Estado na economia. Segundo a revista, "com uma força e convicção que a tornariam conhecida como Dama de Ferro, Thatcher liberou uma economia sitiada por marcos e regulamentações - e, consequentemente estagnada" (NOGUEIRA, 09/02/2009: 73).

$\mathrm{O}$ mecanismo da apreciação de um determinado valor a um acontecimento do presente a partir das consequências de um evento tido como similar no passado é o mesmo da reportagem que fizemos alusão anteriormente. As consequências desastrosas das políticas de Hawley e Smoot é que nos fazem acreditar que - já que estaríamos em uma situação em que as causas dos eventos decorridos e presentes são similares - que este não é o melhor caminho a seguir.

É a este tipo de uso do passado que Hobsbawm (2005) se refere quando diz que a História também engendra em si a ideia de que existe a possibilidade de um cálculo mais ou menos sofisticado que pode procurar pistas no processo de desenvolvimento dos acontecimentos no passado uma forma de tentar delinear o que está por vir. Esta é mesmo uma forma de justificação pela história bastante comum nas revistas pesquisadas e o argumento pragmático se mistura, aqui, a certa futurologia dos acontecimentos apresentados. Assim, a avaliação de uma situação através da significação das consequências de um evento similar no passado ganha, em algumas reportagens, o caráter de facilitador de conjunturas e funciona mesmo como uma forma de julgar o porvir. É através do delineamento de um caminho textual de hipóteses possíveis que ele se constrói.

As reportagens que foram publicadas na ocasião da descoberta do Pré-Sal brasileiro também trazem exemplos interessantes de comparação com uma gama variada de momentos históricos e sobre esta relação que a imprensa estabelece entre a história como um repositório de exemplos e a história que ajuda na delineação de perspectivas para o futuro. A revista IstoÉ, por exemplo, remete a outros ciclos econômicos extrativistas brasileiros:

Lula não exagera ao afirmar que o dia 31 de agosto de 2009 entrará para a história como 'um novo Dia da Independência para o Brasil'. Mas isso só se tornará uma realidade se o país for capaz de não incorrer nos erros do passado. Ao longo dos séculos, o País viveu ciclos extrativistas de caráter predatório. Esvaíram-se fortunas incalculáveis em pau-brasil, ouro, pedras preciosas, cana-de-açúcar, café e borracha (COSTA e NICACIO, 09/09/2009: 38). 
Época prefere fazer referência aos possíveis consequências dos modos de gestão de recurso. No editorial, ela coloca que "a história mundial mostra como o Estado, quando posto a executar funções que não são de sua natureza, tem a capacidade de destruir riqueza" (GUROVITZ, 07/09/2009: 08). Curiosamente, ela não esmiúça quais seriam os eventos da história mundial que confirmariam sua tese.

Já Veja, busca refletir acerca dos ganhos eleitorais que a descoberta poderia trazer e afirma que "petróleo e política, em momentos distintos da história, também funcionaram como um eficiente combustível eleitoral - fórmula que será repetida pelo governo nas eleições presidenciais do ano que vem". Segundo ela, o discurso de Lula no evento do pré-sal “teve o mesmo tom nacionalista de 'O Petróleo é Nosso' de Getúlio Vargas, nos anos 50" (CABRAL, 09/09/2009: 65).

Carta Capital, por fim, buscou comparar o comportamento da imprensa ontem e hoje. Mino Carta separa um editorial de 1953 em que O Estado de São Paulo se mostra contrário à criação da Petrobrás e comenta: "é assustador que, depois de colher as provas da excelência do desenvolvimento iniciado no começo dos anos 50, os argumentos de um lado e de outro sejam os mesmos".

Cada uma destas reportagens citadas se deteve em um fato histórico diferente para a comparação entre o passado e o presente e, desta forma, consequentemente, em cada uma delas, aludiu-se a articulações de sentido diversas sobre o que significa o PréSal para o futuro brasileiro. Mais do que isso, em cada uma delas, apontou-se um agente responsável pelo fracasso ou pelo sucesso deste achado de forma que os antecedentes aludidos funcionam mesmo como forma de delimitar o que é lícito conceber em termos de projetos futuros bem como de agentes responsáveis pela sua realização.

A desconfiança em relação ao papel do Estado nesta empreitada é aludida por IstoÉ, Época e Veja, justamente a partir da avaliação de consequências de eventos que tiveram causas similares no passado (respectivamente os ciclos extrativistas brasileiros, a noção difusa de uma experiência histórica mundial e um julgamento de valor dado à campanha O Petróleo é Nosso).

Quanto a este último, aliás, é bastante interessante notar como o próprio fato histórico já é semantizado a partir de um presente que lhe serve de origem, o que diz respeito à lógica circular que já explicamos anteriormente. Isso fica bastante claro quando lemos a reportagem da Carta Capital que, a partir da remissão ao mesmo evento histórico citado por Veja, constrói outro lugar de sentido, nomeando outros agentes que poderiam contribuir para o fracasso do Pré-Sal (a própria imprensa) e um outro projeto sobre o que esperar deste achado para o presente e para o futuro. 
A partir do mecanismo de funcionamento dos pressupostos e subentendidos, as matérias citadas obedecem, individualmente, ao seguinte esquema:

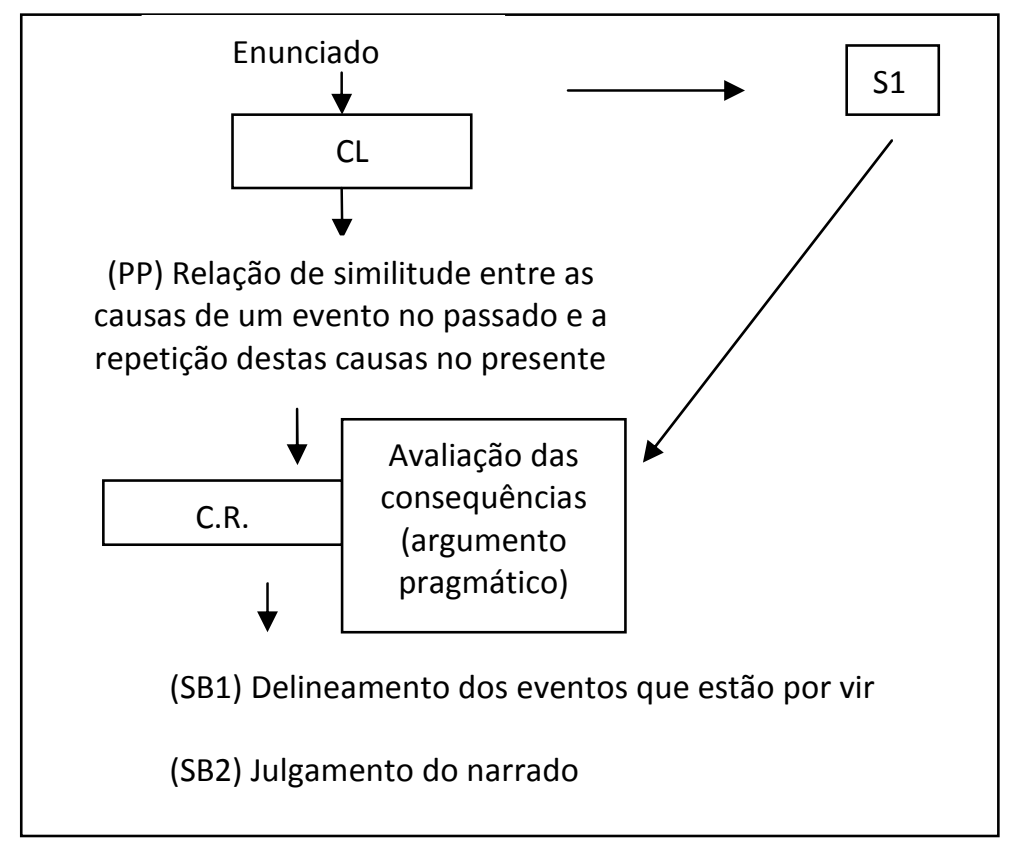

O mecanismo de julgar os acontecimentos presentes com base nas consequências de um evento similar no passado, conforme já havíamos colocado, parte de certo esforço de redução, que limita o conjunto dos efeitos relatados. Para que a transferência de valor opere claramente, é interessante que poucas variáveis estejam postas.

Uma maneira eficiente de diminuir a influência das causas e efeitos complementares é, justamente, fazer menção a eventos passados de ordem traumática. Isso porque o valor das suas consequências já está mais assentado socialmente. Dificilmente alguém discordaria dos efeitos negativos de acontecimentos históricos traumáticos tais como o nazismo, as ditaduras ou os grandes massacres.

O uso de eventos traumáticos como forma de engendrar narrativas comparativas é utilizado, por exemplo, quando a revista Veja afirma, a respeito do projeto de criação de cotas raciais nas universidades federais brasileiras que, "com outras intenções, foi essa mesma ideia absurda a base do único regime contemporâneo erguido sobre o conceito de separação racial, o apartheid da África do Sul, que de 1948 até ser desmontado, em 1994, justificou a segregação entre grupos de pessoas e a supremacia de um deles, os brancos, sobre outro, os negros" (PEREIRA, 04/03/2009: 69). A comparação vai ainda mais longe e os efeitos do regime de cotas chegam a ser comparados com os do regime nazista: 
Em todos os tempos históricos e geográficos, o critério racial como balizador de políticas públicas produziu favoritismos e abusos de poder. Essa maldição foi magistralmente materializada no famoso desabafo de um funcionário nazista exasperado com a vagueza dos critérios instituídos para separar arianos de judeus: 'Na Alemanha, judeu é quem Goebbels (ministro da propaganda) diz que é judeu'. É previsível que, se implantado nacionalmente no Brasil o sistema de cotas, negro será quem o agente do estado petista disser que é negro (PEREIRA, 04/03/2009: 70).

Carta Capital também faz uma remissão ao regime nazista ao discorrer sobre o comportamento da Força-tarefa Norte-americana de Serviços Preventivos, que recomendou a restrição do exame de mamografia para mulheres com menos de 40 anos. Segundo a reportagem, a força tarefa afirmou que não há dados suficientes para afirmar se um câncer irá se espalhar ou não e, assim, não há como afirmar se os exames preventivos poderiam mesmo beneficiar as pessoas ou não. Diante disso, Tuma (02/12/2009: 66) comenta que "essa é uma colocação no mínimo cínica, pois, tirando os tempos de nazismo, não há estudo moralmente sustentável que possa responder a essa pergunta".

O recurso a eventos traumáticos como forma de diminuir a influência de causas complementares funciona porque suas consequências negativas já estão assentadas sob um solo social comum e, assim, isso permite que elas sejam transferidas para os acontecimentos atuais. Obviamente que a comparação ou a similaridade das duas situações podem ser rejeitadas. Não obstante, uma vez aceito que as duas situações são comparáveis, a transferência do valor das consequências é feito de forma bastante natural. A rejeição, neste caso, estaria mais assentada na pertinência da comparação do que na apreciação das consequências.

De uma forma geral, mesmo quando as consequências que servem de parâmetro de análise não estão esmiuçadas pela reportagem, elas podem ser facilmente subentendidas quando estamos lidando com eventos históricos traumáticos. É o caso, por exemplo, da comparação feita por Carta Capital, a respeito das justificativas de Roberto Micheletti para tomar o poder em Honduras: "qualquer semelhança com Pinochet será mera coincidência" (MENEZES, 07/10/2009: 28).

Ou, ainda, na reportagem sobre as manifestações no Irã, cujo possível aumento da violência por parte do governo, segundo a revista Época, "seria um desfecho ao estilo chinês, que em 1989 ordenou o massacre de estudantes na Praça da Paz Celestial, para acabar com manifestações pela democratização do país" (EVELIN e MENDONÇA, 22/06/2009: 100). 
Na coluna de Maílson da Nóbrega, da revista Veja de 17/06/2009, o colunista também utiliza este tipo de recurso ao tratar de uma possível aprovação de uma emenda constitucional que permitiria um terceiro mandato a Lula. Ao explicar por que somente as eleições não garantem uma democracia, ele coloca que "Hitler, Mussolini, Saddam Hussein e Hugo Chávez foram eleitos pelo povo" (NÓBREGA, 17/06/2009: 93).

As consequências dos dispositivos citados não são esmiuçadas pelas reportagens, mas, parece não haver necessidade disso. As famosas imagens da violenta repressão aos manifestantes durante o Massacre da Paz Celestial funcionam como forma de demarcar o possível desfecho negativo dos manifestantes do Irã e a comparação com personalidades assentadamente mal vistas na história mundial (por força do autoritarismo e das violações contra a humanidade em seus governos) força uma comparação de um desfecho similar no caso da aceitação de um terceiro mandato de Lula. No caso desta, aliás, trata-se de uma comparação dupla: não é só o governo Lula que é enquadrado dentro deste conjunto de causas similares e consequências negativas; sendo o único dos quatro parâmetros de comparação que ainda está no poder, também Hugo Chávez é julgado sob este prisma ${ }^{54}$.

Só para citar mais um exemplo, em uma reportagem da revista Época, este recurso é usado de uma forma curiosa. Ao discorrer sobre a política econômica do governo Lula, o repórter coloca que

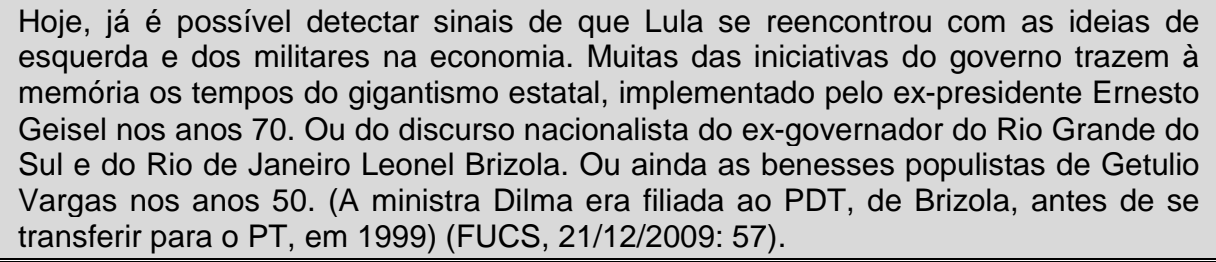
esquerda e dos militares na economia. Muitas das iniciativas do governo trazem à memória os tempos do gigantismo estatal, implementado pelo ex-presidente Ernesto Geisel nos anos 70. Ou do discurso nacionalista do ex-governador do Rio Grande do Sul e do Rio de Janeiro Leonel Brizola. Ou ainda as benesses populistas de Getulio Vargas nos anos 50. (A ministra Dilma era filiada ao PDT, de Brizola, antes de se transferir para o PT, em 1999) (FUCS, 21/12/2009: 57).

\footnotetext{
${ }^{54}$ Veja recorre frequentemente a este tipo de comparação também nas matérias informativas. Só para citar mais um exemplo, na matéria "Más notícias, presidente", ela se pergunta "Por que Hugo Chávez, Evo Morales, Rafael Correa e o casal Kirchner tratam a imprensa como inimiga?". A resposta é inequívoca: "esperam um dia atingir o controle total da informação obtido pelas grandes ditaduras do século passado, prática que é mantida ainda por seus irrelevantes sobreviventes atuais: Cuba e Coreia do Norte" (VEJA, 04/11/2009: 100). Em uma outra reportagem, ela compara as milícias de Chávez com as SS de Hitler. Segundo a reportagem, "O presidente Hugo Chávez deu um passo largo em seu projeto de implantar uma ditadura fascista na Venezuela. Na semana passada, a Assembleia Nacional, dominada por seus partidários, aprovou uma reforma da legislação sobre as Forças Armadas, cujo objetivo foi equiparar as milícias de Chávez aos militares do país. (...) A existência de uma tropa de choque à margem das instituições e diretamente ligada ao líder supremo é uma característica do fascismo. Adolf Hitler chegou a ter duas milícias distintas, cujas ações incluíam maltratar os judeus, dispersar comícios esquerdistas e empastelar jornais. Depois de assumir o poder, ele mandou destruir uma delas, a AS, por causa das desavenças dentro do partido nazista. A outra, a famigerada SS, recebeu armamento pesado e se tornou executora dos abomináveis crimes do regime" (TEIXEIRA, 14/10/2009: 72).
} 
Os modelos de políticas econômicas colocados lado a lado (e que, segundo a reportagem, seriam seguidos por Lula), pouco tem em comum um com o outro. O laço que os une é, justamente, o fato de não serem consensualmente aceitos e, não raro, emanarem alguns ares negativos. Os efeitos de sentido são, assim, bem similares aos esmiuçados nas reportagens anteriores.

Existem, ainda, outros aspectos que podemos explorar que dizem respeito ao uso dos argumentos pragmáticos na comparação entre eventos do presente e fatos do passado.

O argumento pragmático é, de certa forma, um modo de se fundamentar o real pelo recurso ao caso particular, afinal, é através de uma situação específica no passado que podemos julgar as causas e as consequências que estão em jogo na avaliação dos acontecimentos presentes. Existem diversas formas de colocar em ação este mecanismo. "Este pode desempenhar papéis muito variados: como exemplo, permitirá uma generalização; como ilustração, esteará uma regularidade já estabelecida; como modelo, incentivará a imitação" (PERELMAN e OLBRECHTS-TYTECA, 1996: 399).

Um exemplo que podemos destacar, neste sentido, é a reportagem "Por que os corruptos não são punidos no Brasil?”, publicada na revista Época, de 23/03/2009. Com um título bastante auto-explicativo, o texto tenta delinear porque, mesmo com 26 governadores enfrentando pedidos de cassação, as instituições brasileiras atuam de modo tão vagaroso. Para desenvolver o tema, a reportagem utiliza os seguintes termos:

Os deputados que comandaram a Comissão de Orçamento do Congresso, de 1988
a 1993 , conseguiram desviar parte substantiva do Orçamento Federal. O deputado
federal João Alves, principal representante do grupo conhecido como 'Anões do
Orçamento', acumulou US\$30,5 milhões entre 1989 e 1992 . Uma CPI instalada em
outubro de 1993 investigou 43 parlamentares. Destes, 14 foram inocentados. Para
11 , foram sugeridas mais investigações. A cassação foi recomendada para 18.
Quatro parlamentares renunciaram e seis foram cassados. Quase 15 anos após o
fim da investigação, nenhum parlamentar foi punido criminalmente. Ninguém foi para
a cadeia - à exceção do assessor José Carlos Alves dos Santos, mas sob a
acusação de que mandara matar a mulher (MARCHIORI, 23/03/2009: 43).

No contexto da urdidura de enredo posta pela reportagem em questão, o dado histórico citado (bem como a comparação que ele engendra com o presente) funciona como uma ilustração do tema que a revista busca retratar. Isso porque o papel da ilustração é, justamente, "reforçar a adesão a uma regra conhecida e aceita, fornecendo casos particulares que esclarecem o enunciado geral, mostram o interesse deste através da variedade das aplicações possíveis, aumentam-lhe a presença na consciência" (PERELMAN e OLBRECHTS-TYTECA, 1996: 407). 
Ou seja, a falta de punição aos corruptos no Brasil já é mostrada como uma regra aceita e a lembrança dos "Anões do Orçamento" serve apenas como uma forma de reforçar a norma e impor a atenção a este fato. Uma vez mostrada a regularidade das ações, já se alinhava, na matéria, a impressão de que, da mesma forma que aconteceu em casos anteriores, os políticos corruptos não seriam punidos novamente.

Mais do que algo explicitamente escrito ipsis litteris pela matéria, no entanto, essas impressões são fruto de um jogo entre o que está posto e o que está implícito. $\mathrm{O}$ exercício de futurologia está calcado em uma série de pressupostos que dizem respeito às possibilidades de comparação entre passado e presente. Os subtendidos, por sua vez, estão relacionados às expectativas sobre o que pode acontecer no futuro.

Os escândalos políticos de 2009, aliás, mobilizaram usos bastante vastos das funções e sequências narrativas de ordem comparativa com base em argumentos pragmáticos nas reportagens do corpus analisado. Os dados históricos evocados, nestas matérias, no entanto, não se referem somente a eventos que dizem respeito a uma desmoralização dos políticos. Pelo contrário: muitas vezes, as matérias tentavam restabelecer o papel da casa enquanto instituição com base nos efeitos positivos que ela gerou no passado, bem como a falta que ela fez em tempos mais sombrios.

Nestas reportagens, em geral, é utilizado um recurso que fundamenta a argumentação a partir de exemplos.

Como bem explicam Perelman e Olbrechts-Tyteca (1996: 399), esta tática é normalmente utilizada quando há "certo desacordo acerca da regra particular que o exemplo é chamado a fundamentar", com a condição de que esteja suposto "um acordo prévio sobre a própria possibilidade de uma generalização a partir de casos particulares". A evocação de exemplos do passado cuja participação ativa do Congresso teve uma consequência positiva é um recurso utilizado, portanto, para fundamentar uma posição diferente do que parece sugerir os escândalos mais recentes e tenta reafirmar, a partir da costura com os subentendidos, a ideia de que este tipo de poder é importante apesar dos problemas que carrega.

É o caso da reportagem da revista Veja que, depois de noticiar uma série de casos de corrupção, afirma que "mesmo quando o Congresso produz pouco e está mergulhado em escândalo, como ocorre agora no Brasil, seu simples funcionamento serve como anteparo contra medidas antidemocráticas" (CABRAL, 29/04/2009: 71). Através da utilização de exemplos históricos e de suas consequências, delineia-se um quadro a partir do qual se mostra a necessidade de um Congresso forte: 
Hoje o Congresso pode rejeitar propostas do Executivo, derrubar vetos do presidente a leis, propor legislação de iniciativa popular, criar CPIs para investigar corrupção nos outros poderes e, em caso extremo, até mesmo cassar o mandato de um presidente corrupto, como aconteceu com Fernando Collor de Mello. Sem Congresso, nada disso seria possível e o presidente teria plenos poderes. Poderia fechar o Judiciário, criar tribunais de exceção contra adversários, prender, torturar, praticar corrupção sem ser incomodado e perpetuar-se no poder. E isso não é apenas suposição. A história confirma todas essas possibilidades. Getulio Vargas governou o Brasil de 1930 a 1934 sem Legislativo, quando prendeu adversários e perseguiu inimigos. De 1937 a 1945, novamente Getulio fechou o Congresso, criou um tribunal político e decidiu unilateralmente a entrada do Brasil na guerra. No regime militar, o Congresso foi fechado em 1968 para a instituição do Al-5, que restringia as liberdades individuais (CABRAL, 29/04/2009: 71).

A reafirmação dos valores democráticos (apesar das crises e dos escândalos) também é um tema explorado pela reportagem da revista IstoÉ, "Quando o Congresso dava resultado" - que, aliás, na diagramação da revista, é alocada logo em seguida à reportagem que noticiava os escândalos mais recentes. Segundo ela, "antes de ceder ao conluio formado por imposições do baixo clero, a lideranças reticentes e à omissão diante de medidas provisórias, o Parlamento deu aos brasileiros a rede de proteção social que hoje atenua os efeitos da crise econômica" (SUASSUNA, 29/04/2009: 45).

Entre estes atenuadores da crise mundial, a reportagem cita que "em 1986, foi por imposição de políticos que os economistas do Plano Cruzado e os tecnocratas do governo criaram o salário-desemprego, velha reivindicação do movimento sindical". Também, "em 1988, os constituintes contrariaram a pressão do empresariado para criar uma série de novos direitos sociais. A licença-maternidade passou de três para quatro meses, garantiu-se a renda mínima para trabalhadores rurais que nunca contribuíram com a Previdência Social, reduziu-se a jornada de trabalho (...)". Por fim, conclui-se que "só quem um dia viveu sem ele sabe: Congresso até quando é ruim, é bom. Porque dá vazão política e estabilidade legal aos conflitos do país. Quando vai bem, como no início da redemocratização, é um agente de mudanças. Quando vai mal, precisa ser mudado" (SUASSUNA, 29/04/2009: 45-46).

No caso desta reportagem, podemos notar que a transferência do valor das consequências aludidas é dada não apenas através de uma situação em que os efeitos do passado são iguais aos do presente. Ela é posta também a partir de uma situação em que o decorrido que serve como o modelo da comparação é diferente da atualidade observada, mas, não obstante, esta realidade é desejável e/ou possível. O passado aludido não é apresentado como comparável ao presente, mas sim, a um presente idealizado ou almejado.

Outro exemplo está na matéria de IstoÉ, "Um golpe fora de época", sobre os problemas políticos em Honduras. Ao comparar dois eventos (um do passado e um do 
presente), a revista identifica causas diversas nos dois fenômenos o que, em última instância, acabam por remeter também a consequências distintas. Segundo a reportagem, "os tempos de golpes militares na América Latina, que tiveram seu auge na Guerra Fria, parecem ter chegado ao fim. Uma reação internacional sem precedentes se seguiu à manobra militar que retirou do poder o presidente de Honduras, Manuel Zelaya" (VILLAMÉA, 08/07/2009: 100). A ideia é ainda reforçada no fecho da reportagem, quando a repórter coloca que "afinal, o último golpe de Estado bem sucedido na América Latina ocorreu em 1992, quando, com o apoio das Forças Armadas, o peruano Alberto Fujimori fechou o Congresso e suspendeu as garantias constitucionais" (VILLAMÉA, 08/07/2009: 101).

Em nenhum momento da reportagem, é afirmado categoricamente que o golpe não funcionaria. Não obstante, ao declarar encerrada a época em que os golpes militares costumavam ser bem-sucedidos na América Latina, a ideia fica bastante clara no nível dos subentendidos.

Da mesma forma que anteriormente, este efeito de sentido poderia seguir o seguinte esquema:

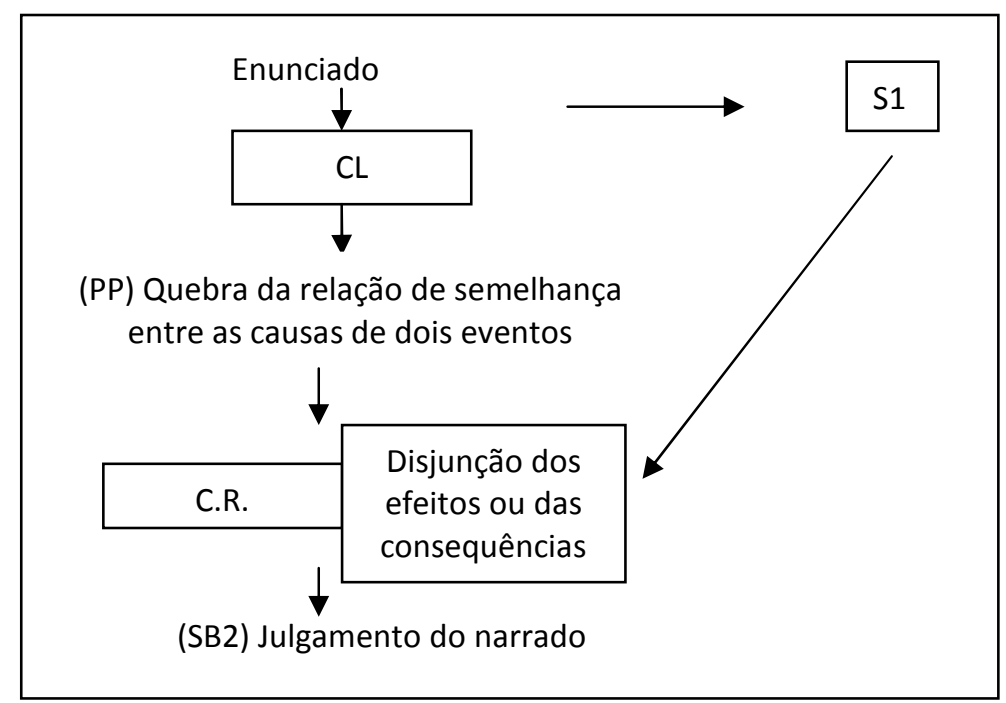

Embora tenhamos isolado as narrativas de comparação e as de disjunção, é bastante comum que elas apareçam juntas em uma mesma reportagem. Podemos destacar como exemplo a matéria "UNE chapa branca", publicada na revista Veja, que critica a organização afirmando que "a entidade que representa os estudantes brasileiros envergonha sua história com o protesto a favor do governo, pago pelos cofres públicos". Segundo a reportagem: 
Talvez Brasília só tenha assistido a tamanho servilismo por parte dos estudantes universitários brasileiros quando, no regime militar, foi organizada a Arena Jovem, braço do partido de sustentação do governo. A atual geração está jogando na lama a rica história da UNE de enfrentamento com o poder. Não apenas de contestação, mas de produção cultural alternativa de qualidade nos anos 60 - quando foi presidida por José Serra, hoje governador de São Paulo (RIBEIRO, 29/07/2009: 76).

Em um só golpe, os fatos históricos evocados nesta reportagem marcam tanto a forma como a UNE atual deve ser vista quanto o que é ela não é mais. Ela marca as rupturas instaladas através de uma sequência narrativa de disjunção (que diz que a UNE não é mais a entidade responsável por uma produção cultural alternativa de qualidade como era nos anos 60), bem como as comparações que devem ser tomadas como válidas (como quando ela serviu ao regime militar). São essas rupturas e continuidades que formam o entendimento de como a entidade deve ser enxergada e, talvez mais do que isso, ter suas ações julgadas.

As narrativas que recorrem aos argumentos pragmáticos, no entanto, não são as únicas que se fazem a partir de uma relação de solidariedade ou de ruptura em relação ao passado. As sequências e funções narrativas de ordem comparativa e de disjunção apresentam outros efeitos de sentido em alguns textos, conforme mostraremos a seguir.

\section{2. $O$ deliberado e o involuntário: o jogo entre as finalidades e as consequências nas funções narrativas de ordem comparativa e de disjunção}

Algumas narrativas jornalísticas que fazem alusões a eventos históricos se estruturam de uma maneira diferente da que vínhamos analisando até então. Nas matérias publicadas a respeito das plásticas realizadas por Dilma Rousseff podemos observar isso de maneira clara. Os fatos históricos selecionados foram bastante diversos em cada uma das publicações, mas eles apontavam para uma mesma construção de efeitos de sentido.

Ao explicar a lógica envolvida na mudança de visual da futura candidata à presidência, a revista Época evoca o seguinte precedente histórico: “a visão é mais ou menos assim: em 1989, na eleição de Fernando Collor, o país votou num candidato que tinha a imagem da juventude. Com Lula e sua biografia, votou no 'social'. Na visão de Duda Mendonça, ainda não se explorou o terreno da candidata feminina" (CLEMENTE e LEITÃO, 19/01/2009: 31).

As comparações feitas por IstoÉ não são tão diferentes e apelam também para a assunção de que os políticos costumam ser, ao longo da história, visualmente construídos. Sua ênfase, porém, é ligeiramente outra. Segundo a reportagem: "Lula 
partiu de sua própria experiência. Ele mesmo só conseguiu eleger-se presidente depois que amenizou o seu aspecto de líder sindical raivoso. O candidato à presidência de 1989 não se preocupava com a longa barba negra desgrenhada e nem com os paletós mal cortados. Ria pouco e usava um tom de voz agressivo". Acrescenta, ainda, que a mudança do presidente não se limitou ao discurso, mas "levou em conta aparar a barba, adotar um corte de cabelo mais moderno e começar a usar ternos feitos por estilistas, como Ricardo Almeida" (LAGO e PARDELLAS, 21/01/2009: 40).

Há, ainda, uma outra comparação histórica, mostrando que a atitude da ministra não é exatamente recente. "Dilma não inova. O médico brasileiro [Ivo Pitanguy] lembrou que o cardeal Richelieu (1585-1642) puxava os cabelos para trás numa tentativa de demonstrar mais força. 'Foi uma maneira de mostrar um rosto mais determinado"” (LAGO e PARDELLAS, 21/01/2009: 40).

A reportagem publicada na revista Veja parte de uma construção diferente das anteriores. Apesar de versar também sobre o que ela chama de "PAC da ministra" ("Plano de Aprimoramento Cosmético"), a reportagem rapidamente se volta à discussão sobre as chances de Dilma em substituir Lula. Para analisar a questão, a reportagem afirma que são raras as aparições de candidatos pouco conhecidos do eleitorado e que não tenham concorrido a cargos eleitorais anteriormente. Não obstante, "já aconteceu antes":

Em 1910, para ficar apenas no século passado, o presidente Nilo Peçanha lançou a candidatura de Hermes da Fonseca que nunca disputara eleição e tinha como principal atributo político ser sobrinho de Deodoro da Fonseca, herói da Proclamação da República. Hermes da Fonseca derrotou o escritor e diplomata Rui Barbosa e foi eleito presidente da República (CABRAL, 21/01/2009: 66-67).

Logo em seguida, acrescenta:

Mais recentemente, em1960, Juscelino Kubitschek inventou a candidatura de um ministro sem experiência eleitoral, Henrique Lott. Mesmo apoiado por um presidente muito popular, Lott foi derrotado por Jânio Quadros. Suspeita-se que JK tenha apoiado Lott apenas para que ele perdesse a eleição, certo de que voltaria ao poder cinco anos depois. Há, atualmente, suspeita parecida no serpentário de Brasília. A derrota da ministra, segundo esse ponto de vista, pavimentaria o caminho para a volta de Lula ao Planalto em 2015. Se a intenção de JK foi realmente essa, nunca se soube. A renúncia de Jânio e a instalação do regime militar impediram sua volta ao governo. No caso de Lula, a história ainda está para ser escrita (CABRAL, 21/01/2009: 67).

Há uma construção de sentido digna de nota nesta reportagem de Veja. Isso porque as reminiscências históricas evocadas instauram um jogo entre, de um lado, uma natureza involuntária e, de outro, uma condição deliberada das consequências das 
manobras políticas. A comparação das possibilidades de reeleição de Dilma com um evento em que o desfecho final pode ser lido como uma consequência (caso da comparação com Hermes da Fonseca) e com outro em que ele é posto como similar a uma finalidade (no confronto com Kubitschek), instaura mesmo um campo em que as articulações políticas podem ter duas leituras completamente diferentes.

Como colocam Perelman e Olbrechts-Tyteca (1996: 308), "um mesmo acontecimento será interpretado e valorizado diferentemente, conforme a ideia que se forma da natureza, deliberada ou involuntária, de suas consequências. (...) Conforme se conceba a sucessão causal, sob o aspecto da relação 'fato-consequência' ou 'meio-fim', a ênfase será dada ora ao primeiro, ora ao segundo dos dois termos". Isso significa que na apresentação de um evento tal como uma consequência de um conjunto de situações, instaura-se aí uma articulação de sentidos que proporciona uma minimização de seus efeitos. Por outro lado, se este mesmo evento for apresentado tal como uma finalidade ou algo feito de forma deliberada, há mesmo um aumento de sua importância.

A comparação da possível eleição de Dilma com eventos de naturezas diferentes, neste sentido, articula mesmo este jogo entre uma apreciação positiva a respeito da campanha da ministra e outra altamente depreciativa. Os dados históricos, em cada uma das sequências narrativas históricas evocadas engendram diferentes pressupostos e subentendidos. Eles estão relacionados, no primeiro termo, a um jogo político que, embora inesperado, é legítimo; já no segundo, a um tipo de manipulação da opinião pública com finalidades escusas e questionáveis.

Mais do que algo posto ipsis litteris pela revista, no entanto, esta articulação foi construída a partir dos dados históricos apresentados, adquirindo, assim, uma legitimidade e a impressão de que se trata de uma análise comedida, feita apenas nos termos de uma comparação.

Este jogo entre o deliberado e o consequêncial também está posto nas reportagens das revistas Época e IstoÉ. A primeira, ao tratar as plásticas de Dilma como uma construção do "feminino" do marqueteiro Duda Mendonça (um personagem não muito bem quisto por um histórico de envolvimento em manobras políticas suspeitas) tal como Collor (um personagem ainda mais consensualmente desvalorizado) havia construído uma imagem da "juventude" e Lula uma do "social", engendra mesmo um juízo bastante depreciativo em relação à ação de Dilma.

Especialmente a comparação com Collor - ao aludir a um evento traumático do passado político nacional, em que um candidato que se apresentava como uma espécie de renovador dos costumes políticos acaba com o mandato impugnado - cria uma 
impressão de suspeição contra a construção de personalidades políticas desta maneira. A colocação de Collor e Dilma lado a lado contribui decisivamente para a depreciação do fato de a ministra ter recorrido a plásticas.

Não é muito diferente da comparação entre a candidata e o cardeal Richelieu evocada por IstoÉ. O ponto de costura do enredo, aqui, está na edificação de uma comparação com um personagem que também teve que construir deliberadamente uma imagem que não lhe era natural.

É justamente a partir de uma espécie de denúncia de um engodo que tanto Época quanto $I s t o E ́$ - assim como Veja, mesmo que de uma maneira diferente - posicionam suas remissões históricas. A comparação com Lula, muito embora seja feita de uma maneira mais suave, remete a este mesmo tipo de mecanismo de construção de sentidos.

Podemos pensar estas articulações a partir do seguinte esquema, no caso das matérias citadas:

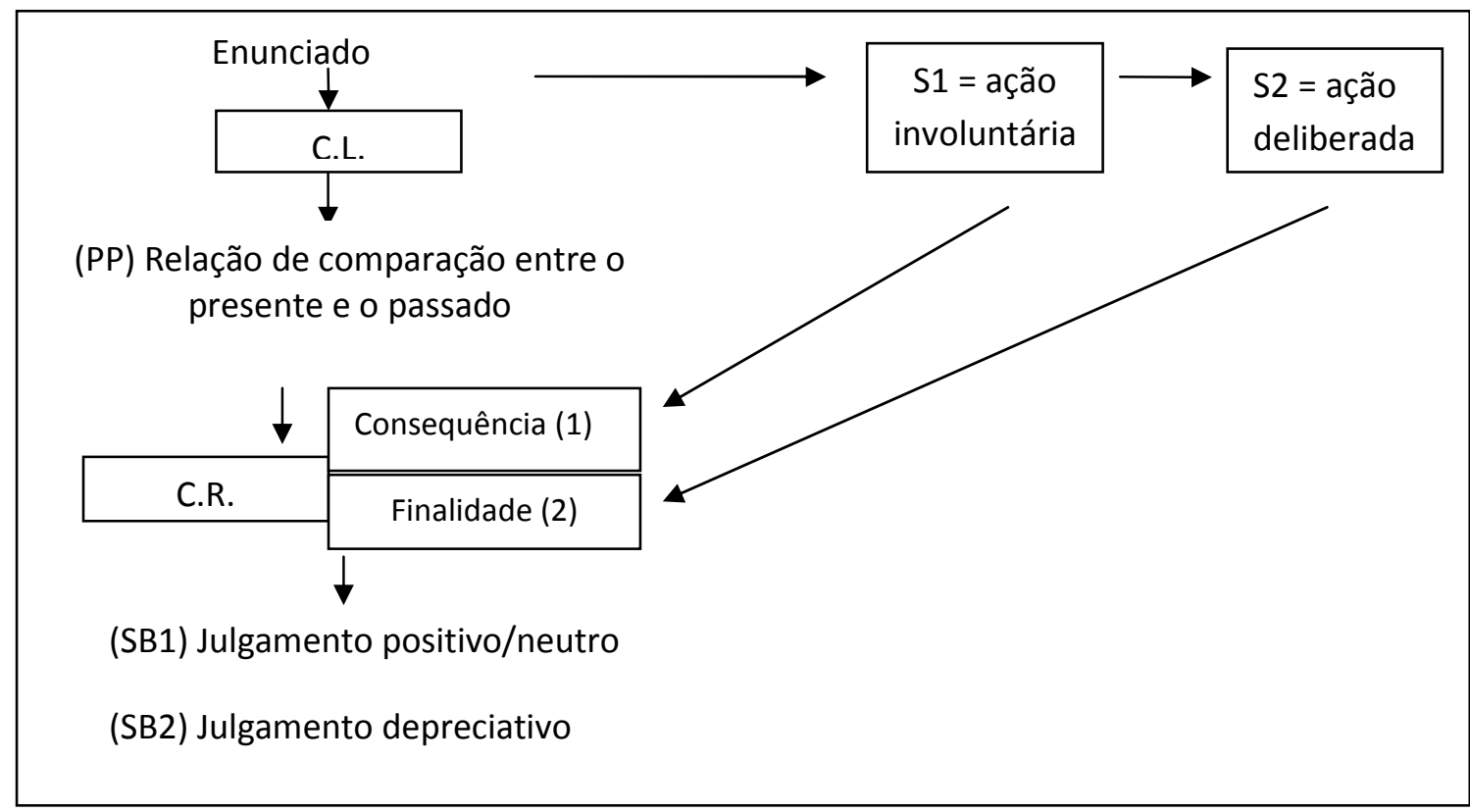

O jogo entre o que se apresenta como uma consequência ou como uma finalidade instaura a articulação de diferentes subentendidos. Enquanto construtores de lugares de sentido, estes marcam mesmo a forma como o evento deve ser julgado de maneira que circunscrevem determinados campos de negatividade ou positividade em torno do evento relatado. Podemos ver que, de uma forma geral, essa é uma característica que marca várias das reportagens que foram analisadas até o momento, de maneira que o evento histórico construído como norteador do presente estabelece mesmo determinados julgamentos de valor em torno dos temas da atualidade noticiada. 


\section{Enquadramentos comparativos: alusões históricas como analogia}

Alguns tipos de comparações entre eventos do passado e acontecimentos do presente não são julgados apenas em relação ao valor de suas consequências ou a partir da forma como o efeito do ato é engendrado (como consequência ou como finalidade). A comparação entre dois fatos serve, muitas vezes, como uma forma de enquadrar o atual através de uma similitude de relações.

Um exemplo disso é a reportagem "O sal da terra", publicada na Carta Capital, de 27/05/2009. Ao versar sobre o tema da estrutura agrária brasileira e o Movimento dos Trabalhadores Rurais sem Terra, a revista é bastante simpática ao movimento (uma postura, em geral, bastante recorrente nesta publicação) e o retrata mesmo como um grupo que, tendo sido "criado há 25 anos (...) tornou a luta por terra menos desigual". No parágrafo final da matéria, fechando a narrativa, a revista coloca que:

Pode ser que o MST não dure mais 25 anos. Antes dele sucumbiram Antônio
Conselheiro e Canudos, Francisco Julião e as Ligas Camponesas. Gente
demonizada e abatida a tiro, detida à força. A truculência sempre é uma saída fácil
para sufocar um incômodo. Mas não tem o poder de extirpá-lo para sempre.
Enquanto o Brasil conviver com uma estrutura arcaica no campo, os deserdados se
multiplicarão. E haverá quem resolva organizá-los. Tenha o nome Stedile ou outro
qualquer (LIRIO, $27 / 05 / 2009: 71)$.

Também na Carta Capital, em 17/06/2009, o confronto ocorrido entre a Polícia Militar e estudantes universitários dentro do campus da Universidade de São Paulo é descrito nos seguintes termos: "força pública versus multidão, numa sequência de imagens que faz lembrar outros tempos, quando estudantes enfrentavam a polícia para protestar contra a ditadura" (CARTA CAPITAL, 17/06/2009: 18).

Estas duas reportagens não aludem, propriamente, a uma suposta similitude de causas de eventos no passado e no presente que podem levar a um mesmo conjunto de consequências ou de finalidades, como vínhamos analisando até o presente momento. A relação que ela estabelece entre o atual e o decorrido é outra e está mais vinculada, aqui, ao assentamento de uma similitude de relações que permite enquadrar o apresentado de acordo com alguns parâmetros postos pela comparação. Isso significa, através do estabelecimento de uma analogia.

As analogias históricas não são meras figuras de comparação entre uma situação do passado e um acontecimento do presente. De acordo com Perelman (1997), as analogias são figuras retóricas que constroem uma estrutura do real que permite provar uma verdade graças a uma semelhança de relações.

Ela não se limita a uma simples similitude entre termos, ou seja, "se afirmarmos que A é B (esse homem é uma raposa), não se tratará, pois de uma analogia, e sim de 
uma metáfora" (PERELMAN, 1997: 334). A analogia também difere de outros tipos de enquadramento como a ilustração ou o exemplo porque esta relação que ela estabelece se dá entre áreas diferentes e que não podem ser subsumidas de uma estrutura comum ${ }^{55}$.

O esquema da analogia pode ser descrito a partir da afirmação de que A está para B assim como C está para D. Perelman explica que é fundamental que o primeiro par (A-B) seja menos conhecido do que o segundo, que o deve estruturar graças à analogia. Desta forma, elas deslocam a adesão do indivíduo ouvinte daquilo que é conhecido para o que é desconhecido.

Neste mesmo sentido, Breton (1999) esclarece que os argumentos analógicos implicam um raciocínio que suponha ou que invente um vínculo entre duas zonas do real. Este vínculo, no entanto, não se faz ao longo de uma cadeia contínua. Ele se constrói em um espaço descontínuo através do qual os enunciados se permitem alguns saltos (que dificilmente seriam justificáveis em outras circunstâncias). "A ponte lançada entre as duas zonas do real se justifica assim apenas porque ela permite passar de uma margem a outra" (BRETON, 1999: 131).

A analogia está estruturada a partir de uma transferência de valor do conhecido para o que está com o sentido em disputa. No caso das matérias analisadas, o conhecido, logicamente, está estruturado em torno do decorrido e a similitude de relações é a responsável por estabelecer direções de sentido para os acontecimentos do presente.

Utilizando-se deste mecanismo, a reportagem pode afirmar que a ação do MST está alocada na atualidade assim como a atuação de Antônio Conselheiro ou Francisco Julião estavam postas no passado. A similitude de relações é facilmente percebida através dos marcadores de pressuposição ("antes deles sucumbiram", "sempre” ou "tenha o nome"). A transferência de valor está no nível dos subentendidos e diz respeito a certa dignificação da ação do MST, dispondo o julgamento das ações do grupo em uma esfera positivada.

O mesmo pode ser dito a respeito da segunda reportagem, onde a similitude de relações estabelecida pelos marcadores de pressuposição ("faz lembrar outros tempos") marca que a atuação da PM na USP está inserida na atualidade da mesma forma que a sua ação estava alocada durante o regime militar. A construção desta sequência

\footnotetext{
${ }^{55}$ Segundo Perelman e Olbrechts-Tyteca (1996: 425), "para haver analogia, tema e foro devem pertencer a áreas diferentes: quando as duas relações que confrontamos pertencem a uma mesma área e podem ser subsumidas sob uma estrutura comum, a analogia é trocada por um raciocínio pelo exemplo ou pela ilustração, pois tema e foro fornecem dois casos particulares de uma mesma regra. Por isso, enquanto certos raciocínios se apresentam indiscutivelmente como analogias (é o que acontece com muita frequência quando o foro é tirado do domínio sensível, o tema do domínio espiritual), outros provocam certas dúvidas a esse respeito".
} 
narrativa, neste caso, está ancorada sob uma analogia de três termos que estabelece, no nível dos subentendidos, uma imagem negativa da atuação da polícia com base na transferência dos valores negativos da ditadura militar (e isso, independentemente das consequências que possam ser aludidas).

Outra reportagem interessante neste sentido foi publicada por IstoÉ com o título "Outros muros que precisam cair". Durante as comemorações da queda do Muro de Berlim, o texto relembra que "o mundo lembra e festeja a reunificação de Berlim, mas ainda existem 7500 quilômetros de barreiras separando fronteiras":

A última grande fronteira da Guerra Fria tem quatro mil metros de largura e 245 quilômetros de extensão e separa a capitalista República da Coreia da comunista República Popular da Coreia, no leste da Ásia. Enquanto o mundo comemora os 20 anos da queda do Muro de Berlim na semana passada, a cerca do arame farpado estabelecida sob o cessar-fogo em 1953 ficou repleta de pedidos de reunificação das duas Coreias (ISTOÉ, 18/11/2009: 102).

São citados, ainda, outros lugares que vivem situações semelhantes. Ao remeter a uma fórmula que se aproxima de uma formulação do tipo "esses outros muros estão para hoje assim como o Muro de Berlim estava para o passado", a reportagem delimita um sentido bastante preciso e direcionado a partir do qual podemos avaliar esses tipos de fronteiras. Elas devem significar algo muito parecido com o que significou o Muro de Berlim, não representando somente uma divisão entre Estados.

Levando-se em consideração as matérias citadas, o esquema geral desta construção de sentido pode ser resumido no seguinte quadro:

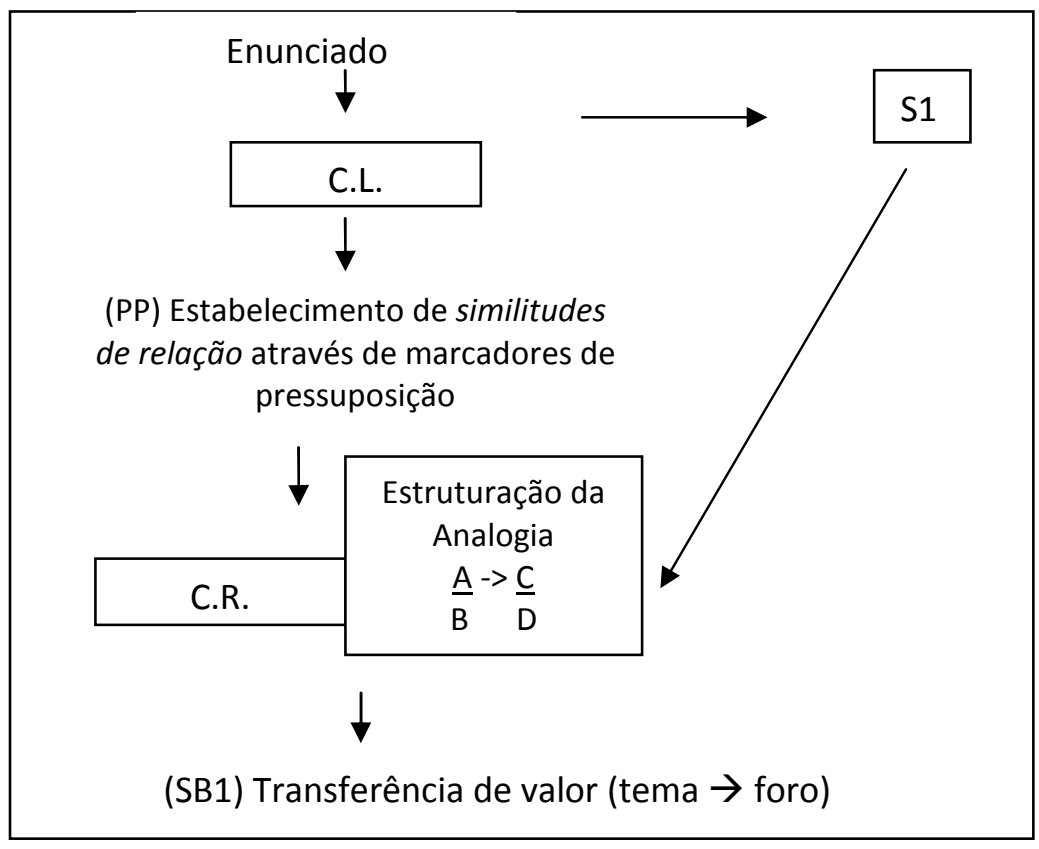


O estabelecimento de analogias pode ser igualmente estruturado a partir de funções e sequências narrativas de disjunção. Elas ocorrem, normalmente, quando uma similitude de relações é negada e, desta forma, afirma-se que o passado não pode ser tomado como similar ao presente. A rejeição da analogia, obviamente, também delineia alguns modos de entendimento em torno do ocorrido.

Frequentemente, aliás, as reportagens combinam as funções e sequências narrativas de comparação com as de disjunção para estabelecer quais são as analogias válidas e quais devem ser ignoradas para o entendimento de um tema.

Um exemplo interessante disso está na reportagem "Por que a ira do Irã", publicada pela Carta Capital. Neste texto, afirma-se que "o regime de Khamenei e Ahmadinejad é autoritário, mas não primitivo, nazista ou louco". Ele coloca que "é preciso ter em mente que os aiatolás, caricatura à parte, não querem um retorno à Idade Média ou (como quer a Veja) 'às cavernas', e sim uma modernização sob seu controle". Também é preciso considerar que a negação do Holocausto "é vergonhosa, mas não faz do Irã outro III Reich. Ao contrário do Xá, de Saddam Husseim, do Paquistão e de Israel, o regime dos aiatolás jamais atacou vizinhos ou reivindicou seus territórios". E é por isso que, segundo a reportagem, "como a antiga União Soviética, o Irã tem sido conduzido de maneira rígida, mas sensata" (COSTA, 25/11/2009: 59-61).

O que se observa, aqui, é a rejeição de algumas analogias para o estabelecimento de outras, circunscrevendo algumas significações bem delineadas em torno da temática proposta, de forma que a analogia pode servir tanto para exaltar quanto para desmerecer alguma ação do presente.

Ao estabelecer uma relação de semelhança entre duas coisas que inicialmente estavam separadas, a analogia histórica se torna um recurso comum nos jogos de produção de sentido na construção das reportagens jornalísticas.

\section{Funções de ordem comparativa quase-lógicas:}

As funções narrativas comparativas quase-lógicas dizem respeito, conforme já havíamos explicado, a remissões ao passado que funcionam com base em raciocínios formais, lógicos ou matemáticos. Trata-se de um tipo de recurso que confronta vários objetos para, então, avaliá-los uns em relação aos outros. Essa comparação, no entanto, não deve ser confundida com a posta por uma relação de analogia ou de semelhança. Ela se distingue por sempre apresentar uma ideia de medição subjacente aos enunciados, mesmo diante da impossibilidade de um cálculo real ${ }^{56}$. É por isso que um

\footnotetext{
${ }^{56}$ Como bem explicam Perelman e Olbrechts-Tyteca (1996: 219), este tipo de construção é chamada de "quase-lógica" porque quem as submete a uma análise lógica "percebe as diferenças entre essas
} 
dos efeitos de sentido envolvidos nas funções comparativas quase-lógicas é a de conferir aos problemas certo caráter empírico.

Muito embora elas possam se organizar através de uma relação de oposição (este é mais forte do que aquele), de ordenamento (o que é mais forte que) ou de ordenação quantitativa (ele é dez vezes mais forte que), a escolha dos termos em que se efetuará a comparação nunca é inocente e sempre engendra significados. Isto porque, como expõe Perelman e Olbrechts-Tyteca (1996: 278): "a escolha dos termos de comparação adaptados ao auditório pode ser um elemento essencial da eficácia de um argumento, mesmo quando se trata da comparação numericamente especificável”. E isso porque "haverá vantagem, em certos casos, em descrever um país como tendo nove vezes o tamanho da França em vez de descrevê-lo como tendo a metade do tamanho do Brasil".

As porcentagens que comparam o estado de uma determinada questão no passado à sua posição relativa no presente a partir de dados aparentemente mensuráveis, portanto, resume o que entendemos como funções narrativas quase-lógicas.

A reportagem "O emprego em xeque", publicada na Carta Capital, de 25/03/2009 é um bom exemplo disso e contém vários tipos de comparações quaselógicas. Nesta matéria, os padrões de crescimento do desemprego em crises anteriores serviam como parâmetro para o delineamento de uma conjectura a respeito do tema para a crise atual. Ela colocava que:

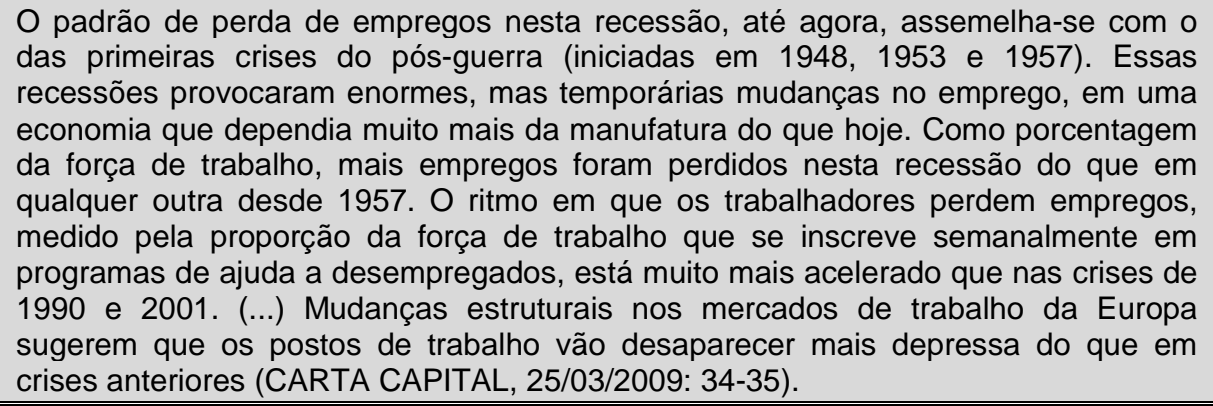
economia que dependia muito mais da manufatura do que hoje. Como porcentagem da força de trabalho, mais empregos foram perdidos nesta recessão do que em qualquer outra desde 1957. O ritmo em que os trabalhadores perdem empregos, medido pela proporção da força de trabalho que se inscreve semanalmente em programas de ajuda a desempregados, está muito mais acelerado que nas crises de 1990 e 2001. (...) Mudanças estruturais nos mercados de trabalho da Europa sugerem que os postos de trabalho vão desaparecer mais depressa do que em crises anteriores (CARTA CAPITAL, 25/03/2009: 34-35).

\footnotetext{
argumentações e as demonstrações formais, pois apenas um esforço de redução ou de precisão, de natureza não formal, permite dar a tais argumentos uma aparência demonstrativa". É por isso que "em todo argumento quase-lógico convêm por em evidência, primeiro, o esquema formal que serve de molde à construção do argumento, depois, as operações de redução que permitem inserir os dados nesse esquema e visam torná-los comparáveis, semelhantes, homogêneos". Para estes autores (1996: 274-275), "ao afirmar 'suas faces são vermelhas como maçãs', bem como ao afirmar 'Paris tem três vezes mais habitantes do que Bruxelas', ou 'ele e mais belo que Adonis', comparamos realidades entre si, e isto de uma forma que parece muito mais suscetível de prova do que um mero juízo de semelhança ou analogia". É justamente pelo fato de que, normalmente, os critérios para essa medição pressuposta estejam ausentes, que se pode chamar esses argumentos de quase-lógicos. Eles "são em geral apresentados como constatações de fato, enquanto a relação de igualdade ou de desigualdade afirmada só constitui, em geral, uma pretensão do orador".
} 
Dentro do corpus pesquisado encontramos, no período de Janeiro a Dezembro de 2009, um total de 441 matérias que utilizavam dados estatísticos ou dados apoiados em relações numéricas de longo espectro temporal - como, por exemplo, comparações do tipo "nas recessões do pós-guerra, a perda mensal de empregos ia de 150 mil a 260 mil. Nesta recessão, a média ainda está em 350 mil" (ROUBINI, 19/08/2009: 61) - na composição da reportagem. Isso corresponde a 39,72\% das funções e sequências narrativas quase-lógicas encontradas.

A divisão em cada uma das revistas analisadas obedece à seguinte tabela:

\begin{tabular}{ccc} 
& Narrativas quase-lógicas & $\begin{array}{c}\text { Narrativas quase-lógicas construídas } \\
\text { a partir de relações numéricas }\end{array}$ \\
\cline { 2 - 3 } Veja & 291 & $128(43,98 \%)$ \\
Época & 326 & $110(33,74 \%)$ \\
IstoÉ & 187 & $76(40,64 \%)$ \\
Carta Capital & 306 & $127(41,5 \%)$ \\
\hline
\end{tabular}

A utilização de estatísticas (especialmente as que são o objeto de nosso estudo, ou seja, àquelas que relacionam as marcações do presente com as do passado) é um recurso importante para o jornalista porque pode apontar tanto para mudanças quanto para tendências de continuidade de determinados dados da realidade (sejam eles econômicos, sociais ou comportamentais).

O que é interessante percebermos, neste caso, é que, embora as estatísticas pareçam dizer respeito a uma escala objetiva de valores, - e isso tem um efeito de sentido bastante importante dentro das narrativas jornalísticas - estes dados só adquirem significação após passarem pela interpretação do jornalista. Ao fazer a distinção entre dado e informação, Setzer (2001) chama a atenção para o fato de que a estatística, por si só, tem pouca relevância uma vez que "não existe significado inerente aos dados. Os dados descrevem apenas uma parte do que aconteceu". Para este autor, "não existe qualquer significado nos dados, eles são apenas representações simbólicas e, por si sós, não possuem qualquer conexão com o que descrevem. Um ser humano deve estabelecer tal conexão". Além disso, os dados não descrevem algo. "Eles simplesmente podem ser a representação de informações, mas também podem ser puro lixo, sem que se possa extrair deles nenhuma informação".

Trata-se, portanto, de uma informação supostamente objetiva, mas que pode estar investida por grandes doses de subjetividade. É justamente sobre este ponto que 
insistem Czeresnia e Albuquerque (1995) quando chamam a atenção para o fato de que “obter dados objetivos de uma análise estatística requer 'input' subjetivo. O reconhecimento da subjetividade inerente à interpretação de dados possibilita que novas evidências possam ser integradas ao conhecimento anterior".

Desta forma, mesmo quando os jornalistas parecem estar lidando com informações matemáticas, que parecem constatações de fato, há ainda aí a marca do orador atrás de uma aparência demonstrativa. É justamente a partir deste reconhecimento que alguns estudiosos interessados em questões metodológicas de pesquisa recorrem à piada de que "dados torturados acabam por confessar qualquer coisa" (JANNUZZI, 1999).

As funções e sequências narrativas quase-lógicas dizem respeito também a um outro tipo de comparação: os superlativos. Eles são responsáveis por reputar a algum objeto a característica de ser superior a todos os outros dispostos em uma série ou, ainda, a afirmação de que ele é único em gênero, sendo, assim, incomparável. Comparações deste tipo produzem efeitos de sentido importantes na medida em que, muito embora enunciados como "o maior evento da história" contenha demonstrações não inteiramente (ou, ao menos, dificilmente) verificáveis, ele, não obstante, prescinde de outros elementos que atestem a importância do ato, pois “já não é necessário compará-lo com qualquer outro para reconhecer-lhe a preeminência" (PERELMAN e OLBRECHTS-TYTECA, 1996: 279). E assim, podemos enfatizar que, para Perelman e Olbrechts-Tyteca (1996: 281), a mensuração que envolve a qualificação de um elemento como quase-lógico não está ligada a um cálculo efetivo, “cujo lugar numa série ou num sistema teria sido fixado de uma vez por todas; não obstante, é a aproximação deles a estruturas matemáticas que fornece grande parte de sua força persuasiva".

Este tipo de utilização das funções e sequências narrativas quase-lógicas - que utiliza expressões como "o melhor desde", “o pior”, “o maior", "a mais alta da história”, ou qualquer expressão que garanta um quê de ineditismo ou de raridade histórica - foi encontrado em 491 matérias do corpus analisado. Um exemplo típico deste tipo de função narrativa quase-lógica são colocações como "[acertou-se] a redução do arsenal nuclear de ambos os países [EUA e Rússia] em cerca de um terço - a maior redução desde o início da Guerra Fria" (CARTA, 15/07/2009: 46). Muito embora estas matérias nem sempre venham acompanhadas de dados estatísticos que confirmem a importância ressaltada pelo superlativo, elas respondem por, aproximadamente, 44,23\% das funções e sequências narrativas quase-lógicas. 
A divisão entre cada uma das revistas é a seguinte:

\begin{tabular}{ccc} 
& Narrativas quase-lógicas & $\begin{array}{c}\text { Narrativas quase-lógicas construídas } \\
\text { a partir de relações numéricas }\end{array}$ \\
\cline { 2 - 3 } Veja & 291 & $112(38,48 \%)$ \\
Época & 326 & $174(53,37 \%)$ \\
IstoÉ & 187 & $84(44,91 \%)$ \\
Carta Capital & 306 & $121(39,54 \%)$ \\
\hline
\end{tabular}

Qualquer dos dois tipos de utilização que considerarmos, no entanto, podemos perceber que as funções narrativas quase-lógicas operam sempre a partir de uma hierarquização de méritos ${ }^{57}$.

Dentro de nosso corpus, há uma incidência bastante acentuada de funções narrativas quase-lógicas (aproximadamente 12\%), de acordo com as características descritas anteriormente. Um assunto, no entanto, tem sido especialmente recorrente nesta categoria, quaisquer dos veículos que tomemos em consideração. Trata-se da crise econômica mundial.

Há inúmeras funções narrativas do tipo "o mundo irá crescer somente 0,5\% em 2009, o nível mais baixo desde a Segunda Guerra Mundial" (COSTA, 04/02/2009: 48), ou "a relativa estabilidade econômica do Brasil diante da atual crise, a maior desde a Grande Depressão de 1929, é notável" (FALCÃO, 21/01/2009: 28). Podemos destacar outros trechos como quando a revista Época coloca que o dinheiro investido pelo governo em bancos durante a crise "é o equivalente a $60 \%$ do Produto Interno Bruto (PIB) dos EUA e 75 vezes os US\$ 115 bilhões destinados pelo Plano Marshal para reconstruir a Europa no final da Segunda Guerra Mundial" (FUCS, 02/03/2009: 56). $\mathrm{Ou}$, ainda, quando Veja coloca que esta é "a mais dramática crise financeira internacional em 80 anos" (BARRUCHO, 24/06/2009: 108).

Para se ter uma ideia da extensão deste recurso, podemos dizer que as quatro revistas analisadas publicaram juntas 311 matérias sobre a crise financeira mundial (241 delas só no primeiro semestre), sendo que algumas delas possuíam algum tipo de remissão histórica e outras não. Destas, 194 (62,37\%) continham uma função narrativa

\footnotetext{
${ }^{57}$ Pudemos encontrar nas revistas, ainda, outros tipos de utilização das sequências e funções narrativas quase-lógicas. Algumas relações envolvem, por exemplo, a ideia de medição de tempo (do tipo "há mais de cinco séculos que o Brasil vive uma situação de pobreza extrema"), ou, ainda, momentos em que a medição se dá somente em termos de "maior" ou "menor" (e não de "o maior" ou "o menor" conforme colocamos anteriormente). Neste último, temos frases como "o descontentamento da população está menor hoje do que há vinte anos". Não obstante, os dados esmiuçados nas tabelas dizem respeito às utilizações mais frequentes.
} 
quase-lógica como as que citamos acima. Isso, sem contar os outros tipos de comparações baseadas em estruturas do real, conforme a distinção que explicitamos anteriormente.

Se considerarmos o total de matérias que possuem funções e sequências narrativas quase-lógicas, somente a pauta da crise econômica mundial foi responsável por quase $10 \%$ do total de textos inseridos nesta categoria. Se considerarmos apenas o primeiro semestre, no entanto, veremos que ela corresponde a aproximadamente $30 \%$ desta categoria.

O mais curioso é que há uma repetição bastante excessiva da Crise de 1929 e dos anos que se seguiram a ela. Destas 194 matérias, 100 delas (aproximadamente 51,54\%) falavam sobre este assunto a partir de uma perspectiva quase-lógica. Nenhum outro fato histórico foi tão insistentemente repetido dentro de nosso corpus:

\begin{tabular}{|cccc|}
\hline Veja & $\begin{array}{c}\text { Total de matérias } \\
\text { publicadas sobre a crise }\end{array}$ & $\begin{array}{c}\text { Matérias que possú́am } \\
\text { funções quase-logicas }\end{array}$ & $\begin{array}{c}\text { Matérias que citavam a } \\
\text { crise de 1929 }\end{array}$ \\
\hline $\begin{array}{c}\text { Época } \\
\text { IstoÉ }\end{array}$ & 72 & $53(73,61 \%)$ & $23(43,39 \%)$ \\
Carta Capital & 105 & $68(64,76 \%)$ & $38(55,88 \%)$ \\
Total & 35 & $16(45,71 \%)$ & $9(56,25 \%)$ \\
\hline $\begin{array}{l}\text { Legenda: As porcentagens nas "matérias que possuíam funções quase-lógicas" estão postas em relação } \\
\text { ao total. As porcentagens nas "matérias que citavam a crise de 1929" estão postas em relação às "matérias } \\
\text { que possuíam funções quase-lógicas". }\end{array}$ & $57(57,57 \%)$ & $30(52,63 \%)$ \\
\hline
\end{tabular}

A partir do gráfico podemos notar que, percentualmente, a revista IstoÉ é que a mais se utilizou do recurso de citar a Crise de 1929 de forma quase-lógica (com $56,25 \%)$, seguida pelas revistas Época $(55,88 \%)$ e Carta Capital $(52,63 \%)$. A Veja, muito embora seja a revista que mais utiliza narrativas quase-lógicas em suas reportagens sobre a crise (com 73,61\%), ela é a publicação que menos cita a Crise de 1929 como parâmetro de análise (isso acontece em 43,36\% dos textos).

Existem algumas teorias que tentam dar conta da problemática da repetição insistente em torno de determinados fatos históricos. Paul Ricoeur, por exemplo, explora as concepções freudianas e, retirando-as de sua atuação sobre o indivíduo, aplica-as aos traumas de uma sociedade.

Para Ricoeur, alguns dos abusos da memória - como os grandes lutos memorialísticos nacionais ou a obsessão com repetição de um determinado evento 
histórico - podem se aproximar do funcionamento freudiano do luto e da repetição. Neste sentido, "pode-se falar em traumatismos coletivos e em feridas da memória coletiva, não apenas num sentido analógico, mas nos termos de uma análise direta" (RICOEUR, 2007: 92).

Assim, o "objeto perdido" de que fala Freud a respeito do "luto" pode ser aplicado, igualmente, a uma perda nacional, como a perda de território ou de riquezas. Desta forma, "as condutas de luto, por se desenvolverem a partir da expressão de aflição até a completa reconciliação com o objeto perdido, são logo ilustradas pelas grandes celebrações funerárias em torno das quais um povo inteiro se reúne”. Da mesma forma, “o excesso de memória lembra muito a compulsão de repetição, a qual, segundo Freud, nos leva a substituir a lembrança verdadeira, pela qual o presente estaria reconciliado com o passado, pela passagem ao ato: quantas violências no mundo valem como acting out no lugar da lembrança!" (RICOEUR, 2007: 92).

Dentro dessa perspectiva, a repetição de um determinado fato histórico adquire o estatuto de uma patologia comparável aos processos que estão inscritos no sujeito só que, desta vez, aplicado a um ambiente social.

De qualquer forma, podemos pensar nestas inserções nas narrativas jornalísticas da mesma maneira com que havíamos tratado os eventos traumáticos anteriormente citados em outras matérias. Eles ajudam a transferir, de forma clara, os valores implicados nas causas para as consequências.

Falar sobre a crise de 1929 em comparação matemática com a crise atual ajuda a articular um enquadramento do evento e confere dramaticidade ao relato.

De uma forma geral, podemos pensar que as sequências e funções comparativas quase-lógicas desempenham um papel importante dentro do jornalismo porque, além dos mecanismos que envolvem os demais tipos de comparação, elas incluem um outro elemento: todas elas engendram a impressão de se estar lidando com uma escala objetiva de valores que serve de parâmetro para a comparação. Esta escala, no entanto, pode ser questionada, seja através do confronto com outros números (provenientes de outras amostragens ou de outras fontes), seja através do uso de outros termos de comparação.

\section{As narrativas de disjunção nas editorias de comportamento e de ciência e tecnologia}

Um aspecto que chama a atenção dentro do corpus pesquisado devido à frequência com que aparece diz respeito ao grande número de matérias que utilizam 
funções e sequências narrativas de disjunção em duas editorias específicas: a de "comportamento" e a de "tecnologia". A ênfase na mudança dos costumes e da moral e no avanço das técnicas são duas temáticas bastante insistentes dentro do corpus estudado e, obviamente, tais modificações não poderiam ser celebradas sem algumas considerações de caráter histórico.

É o caso, por exemplo, da reportagem "Uma história de agressões e mortes", que noticiava casos de violência contra a mulher. Apesar de contar diversas estórias trágicas de mulheres que foram mortas pelo parceiro, a revista delineia um quadro histórico que mostrava como, no passado, a atuação violenta do marido era não só tolerada como, muitas vezes, apoiada por dispositivos legais: "nos tempos do Brasil Colônia, a lei portuguesa permitia que o homem matasse a mulher adúltera e o amante. O Código Penal de 1890 deixava de considerar crime o homicídio praticado sob um estado de 'total perturbação dos sentidos e da inteligência'" (AZEVEDO, 13/04/2009: 49-50).

Isso também está presente na matéria "Padre e conselheiro sexual", publicada na revista IstoÉ, de 10/06/2009. Ao contar a estória do frei Ksawery Knotz, conhecido por seus guias sexuais para católicos, a reportagem nota que:

Nem sempre a relação da Igreja com a sexualidade foi assim tão amistosa. Durante
séculos o catolicismo condenou não só o sexo, mas qualquer atividade que usasse o
corpo como instrumento para o prazer. Em dado momento, o cristianismo chegou a
pregar o casamento continente, no qual não havia união carnal. Entre os casados,
quem sentisse prazer durante a relação sexual era tido como adúltero (LOES,
10/06/2009: 68).

Ao falar sobre biquínis e a prática do topless, Época lembra que "preparar-se para o verão é um gesto recente no curso da história. (...) No final do século XIX, não se tomava sol. As pessoas se vestiam normalmente ao caminhar na praia, e era comum o uso de guarda-chuva e sombrinha para evitar o sol. Nos últimos cem anos, a roupa de praia foi, progressivamente, encolhendo" (NOGUEIRA, 27/07/2009: 98).

Nas matérias de tecnologia, a menção também é frequente. Em um texto sobre os livros eletrônicos, Época comenta que "o Kindle tem o potencial de quebrar a relação que estabelecemos com o papel desde 1439, quando o alemão Johannes Gutenberg inventou a prensa" (FERRARI, DEODATO e PEREIRA, 12/10/2009: 98).

Ou, ainda, a respeito do avanço das máquinas no automobilismo, coloca-se que “segurança nem sempre foi uma preocupação na Fórmula 1. Nos primeiros grandes prêmios, na década de 50, os pilotos não usavam capacete - apenas uma touca de couro e um par de óculos para proteger os olhos do vento e dos choques contra insetos. Além 
disso, não era obrigatória a presença de equipes médicas no circuito para atender os acidentados" (COURA, 05/08/2009: 120).

A remissão ao passado, em matérias deste tipo parece produzir um efeito de sentido bastante preciso: ao remeter a um passado que é totalmente diferente do presente, as funções e sequências narrativas de disjunção ressaltam os aspectos que entendemos como próprios do presente. É sobre este assunto que gostaríamos de nos deter com mais calma no próximo tópico, uma vez que ele diz respeito a algo que podemos ampliar para os demais tipos de funções e sequências narrativas de ordem comparativa.

\section{Sobre as relações constitutivas através do outro e as funções e sequências narrativas de ordem comparativa e de disjunção}

A nova inteligibilidade histórica surgida com o advento da modernidade, conforme havíamos pontuado no capítulo II, monta uma espécie de frente de batalha contra as concepções do tempo que tomavam a natureza humana como imutável. Ou seja, contra as concepções que "ignoravam a dependência dos traços psicológicos, necessidades humanas e a utilidade de determinadas instituições quanto a todo $\mathrm{o}$ conjunto de circunstâncias históricas concretas" (OSSOWSKI, 1964: 223). E é desta forma que a procura do tratamento histórico dos fenômenos vira uma espécie de palavra de ordem que marca toda a inteligibilidade do tempo a partir de então, mesmo que ela se estruture a partir de formulações e tratamentos muito diversos e até conflitantes entre si.

No entanto, como coloca Ossowski (1964: 225), esta espécie de advertência não engendrou a ideia que "os fenômenos surgidos em 'formações' diferentes fossem incomparáveis". De fato, a recorrência ao passado continua a ser um recurso poderoso de conhecimento do mundo.

No começo do capítulo, já havíamos chamado a atenção para o fato de que a linguagem se estrutura a partir de relações opositivas. Seguindo os passos de Vogt (2009) precisamos retomar este tema, para pensarmos a forma como passado e presente são confrontados nas funções e sequências narrativas de ordem comparativa e de disjunção nas construções das reportagens jornalísticas.

Para Vogt, as relações comparativas na língua são muito mais frequentes do que normalmente a nossa percepção comum acerca do mundo pode sugerir. Segundo ele, as construções que colocam na balança dois dados com a intenção de medi-los - quer expressem relações de concessão, de excesso ou de compensação (DUCROT, 2009: 12) - se inserem no que ele chama de um intervalo semântico. Esse termo diz respeito a 
determinados elementos da língua que não correspondem a uma espécie de ideia em si, mas sim, a criação de uma orientação do discurso. Assim, "o seu modo de ser é a maneira pela qual eles ligam o discurso a outros discursos no interior da língua" (VOGT, 2009: 32).

Como o próprio Vogt coloca, trata-se de um conceito, portanto, em íntima relação com a noção dos pressupostos da língua, que também sugere essa finalidade de dar uma direção ao discurso.

Para este autor, o comparativo representa uma estrutura privilegiada do intervalo, uma vez que ele guarda em si a força primitiva de um julgamento que "antes de dizer o grau e a medida situa o homem diante do mundo e, de dentro desta situação, confunde-o na subjetividade do ponto de vista" (VOGT, 2009: 33). Este intervalo, no entanto, não se situaria entre os objetos que ele separa e busca comparar (contrariamente ao que a própria palavra intervalo parece sugerir). Ele assume uma relação constitutiva em relação a eles.

Para entendermos essa ideia, recorremos aos mesmos exemplos dados por Vogt, a partir do confronto entre dois tipos de modelos comparativos possíveis.

Em uma primeira abordagem, a comparação entre dois objetos A e B funciona porque eu conheço o que é A e o que é B. Assim, se eu preciso comparar qual é o melhor preço de um produto, por exemplo, basta que eu recorra a uma escala objetiva de valores para que eu possa conhecer os termos da comparação. Assim, eu considero as duas coisas separadamente para depois estabelecer qual é a relação entre elas.

O que Vogt argumenta, no entanto, é o fato de que a maior parte das comparações que fazemos não segue este esquema. Ela obedece a um outro mecanismo que diz respeito ao cotejamento entre elementos que não possuem uma escala objetiva de valores para as qualidades comparadas. Quando eu digo que "Pedro é mais inteligente que João", por exemplo, não há um sistema de medida possível ou uma gradação que me permita situar os termos da comparação.

Isso tem implicações importantes uma vez que, como explica Ducrot (2009: 14), "não apenas a caracterização individual dos termos é frequentemente impossível antes de sua comparação, mas acontece, na maioria das vezes, que esta caracterização é o fim, o objetivo da comparação, e que, portanto, ela não saberia ser senão o seu meio".

Em outras palavras, o mecanismo exposto aqui é o contrário do anterior: a comparação entre a inteligência de Pedro e a de João não tem outra finalidade a não ser determinar o que é Pedro e o que é João. Ela adquire tonalidades formativas uma vez 
que eu constituo a imagem de João ao lhe atribuir a propriedade de ser mais inteligente do que Pedro.

Como explica Ducrot (2009: 14), nestes casos, "a confrontação surge então como um simples instrumento de descrição: a coisa não é aquilo que é senão por referência a uma outra". Assim, a relação aqui não é derivada dos termos e, sim, os constitui. "A relação não está mais fora das coisas, mas nelas".

É importante ressaltar, no entanto, que esse tipo de descrição é de ordem argumentativa. Argumentar, segundo Ducrot (2009: 15), é o ato de "obrigar outrem, através das palavras que pronunciamos, a dirigir-se para tal ou qual tipo de conclusão". E assim, "a significação do enunciado residiria então menos no que ele diz do que na orientação que dá à sequência do discurso" $"$.

Desta forma, se quando eu digo que "Pedro é tão inteligente quanto João" a minha intenção não é dar o quociente intelectual destas duas pessoas, os meus objetivos estão obviamente relacionados a levar o meu interlocutor para alguma conclusão a respeito disso - que pode ser tanto um elogio da inteligência de Pedro quanto uma depreciação da inteligência de João, dependendo do contexto da minha fala.

A partir disso, então, a ideia anterior é expandida. "Não se trata de descrever o que é Pedro nem o que é João. Trata-se de argumentar pró ou contra eles, de orientar em relação a eles a apreciação do interlocutor (este outro necessário para que meu enunciado tenha um sentido, este outro presente na própria significação de minhas palavras" (DUCROT, 2009: 16).

O que isso significa é que esta constituição assumida a partir da comparação dos termos não é de ordem factual, real ou mesmo uma condição prévia para a comparação. Ela é de ordem argumentativa. Ela "diz respeito não ao que é a inteligência de Pedro ou de João, mas ao que disso se deve concluir, às consequências que disso se devem tirar". Isso porque "através da comparação, lanço uma espécie de advertência à pessoa a quem me dirijo: não subestime a inteligência de Pedro (ou não superestime a de João)" (DUCROT, 2009: 17).

As comparações entre acontecimentos históricos e eventos reais parecem também se encaixar neste segundo tipo de comparação exposto por Vogt.

Embora os tipos de comparação que encontramos em nosso corpus (engendradas tanto a partir da aproximação entre o passado e o presente quanto através de seu

\footnotetext{
58 "Descrever uma estrada é descrever, na verdade, descrever para onde ela vai. Porque um enunciado não se assemelharia, neste ponto, a uma estrada (ou a uma encruzilhada, se se quiser considerar as ambiguidades possíveis, que abrem, a partir do mesmo enunciado, várias orientações diferentes, mas não quaisquer orientações)? Esta aproximação não é, aliás, sugerida pela própria palavra sentido, que designa simultaneamente a significação e a direção?" (DUCROT, 2009: 16).
} 
afastamento) sejam diferentes entre si, podemos notar que elas não estão ancoradas em uma escala de valores objetiva, mas sim, a partir de aproximações argumentativas. Isso é válido até mesmo para as sequências e funções narrativas comparativas quase-lógicas, uma vez que, conforme colocamos, os dados que elas trazem adquirem sentido somente a partir da interpretação posta pelo jornalista.

Nas construções textuais analisadas, podemos notar que a comparação entre a situação atual e um evento histórico adquire as tonalidades formativas expostas por Vogt. A lógica em se colocar uma situação do presente como similar a uma crise no passado diz respeito à formação de uma imagem sobre o que significa (ou no que constitui) o fato retratado. Assim, a descrição sobre o que é o fato atual se torna inteligível a partir da referência às situações similares no passado que são elencadas.

Considerando as construções comparativas a partir dos argumentos pragmáticos, por exemplo, podemos notar que o delineamento de um conjunto de consequências ou efeitos similares entre o decorrido e o atual - que funciona como um elemento importante para o julgamento das causas - não apenas delineia possíveis conjunturas para o futuro, como também (ou principalmente) contribui sobremaneira para a formação de determinados enquadramentos sobre o evento do presente retratado. É a partir da comparação que formamos determinadas ideias a respeito da significação do noticiado. Embora isso pudesse ser construído de diferentes maneiras, podemos notar que a comparação atual/decorrido é uma ferramenta importante para formarmos uma imagem descritiva do evento (ou o que ele é).

Este funcionamento adquire alguns contornos ainda mais dramáticos quando pensamos na tensão existente entre eventos cujos efeitos são descritos como finalidades ou como meras consequências. Não é algo intrínseco ao evento que determina em qual dos dois pólos a ação se insere, mas sim, o tipo de comparação histórica utilizada. É ela que determina se o efeito obtido com o ato é intencional ou não. É ela que enquadra o evento e nos informa o que ele é - ao menos argumentativamente.

Isso pode ser estendido de maneira ainda mais óbvia para as analogias - onde é a similitude de relações entre o atual e o decorrido que dota de significação o evento que é descrito no presente - e nas narrativas quase-lógicas - onde a comparação adquire contornos pretensamente mais objetivos.

É principalmente sobre este aspecto que também podemos pensar a respeito das funções e sequências narrativas de disjunção. $\mathrm{O}$ mecanismo utilizado é essencialmente o mesmo, com a diferença de que o enquadramento (ou a informação sobre "o que o evento é") não é posto a partir de uma relação de solidariedade entre o presente e o 
passado, mas sim, através de uma relação de oposição. É a partir da tensão posta pela ruptura entre o atual e o decorrido que é direcionada a significação a respeito do retratado.

A partir deste mecanismo, podemos entender por que há uma utilização tão vasta deste recurso em matérias de comportamento, por exemplo. A significação da descrição de um modo específico de agir é dada não por algum valor positivo ou por alguma característica intrínseca que possamos encontrar neste comportamento; ela é posta (ou é descrita) por oposição ao modo de agir do passado. É a partir da disjunção entre o que foi e o que é que formamos determinada imagem ou julgamento em torno do comportamento retratado.

Nas funções e sequências narrativas de ordem comparativa e de disjunção, as relações entre o atual e o decorrido, desta forma, não dizem respeito a algo que se encontre nos objetos comparados. Ela segue uma orientação que é dada ao interlocutor e acaba por constituir o próprio evento relatado. Trata-se de uma correlação opositiva entre o presente e o passado que passa a definir o próprio presente e argumentar em favor de algum tipo de entendimento em relação a ele.

E isso diz muito a respeito da necessidade do jornalismo pela história e nos informa algo sobre a grande quantidade de material histórico evocado nas reportagens das revistas informativas. Neste sentido, somos obrigados a concordar com Michael Schudson (1987: 84) quando ele coloca que “perguntar 'isto é notícia?' não significa perguntar somente 'isto acabou de acontecer?'. É perguntar ‘isto significa algo?'. E essa questão não pode ser respondida sem serem feitas algumas suposições sobre a História".

E, neste sentido, ao evocar a história, nas matérias citadas, a narrativa jornalística invoca um outro que constitui um presente. 


\section{CAPÍTULO V}

\section{A ORIGEM E OS PONTOS FORTES DA NARRATIVA VINCULAÇÕES DE COEXISTÊNCIA SIMBÓLICA E MARCAS ESSENCIALISTAS}

De uma forma geral, podemos notar certo elogio da exposição do contexto nos manuais que versam sobre a prática jornalística. Isso pode ser observado, por exemplo, nas asserções de alguns teóricos do tipo “informar (...) significa ainda analisar estes atos [dos políticos], expor o contexto em que se praticam, explicar suas consequências possíveis" (SOUZA, 2001: 13). Pode ser notado, ainda, na fala dos próprios jornalistas como na formulação de Carlos Castilho (2007) de que "a determinação do contexto torna-se a principal função do jornalista, que além de apurar a notícia segundo as regras convencionais (...) está tendo agora de dar igual prioridade à descrição dos diferentes contextos sociais, econômicos, políticos e culturais onde o fato aconteceu".

É justamente sobre a falta de uma perspectiva mais ampla relacionada ao contexto que a crítica de Leão Serva se ancora, ao entrever um jornalismo que se preocupa demasiadamente com o presente e se esquece de olhar para as origens das questões. A demarcação de inícios mais remotos, na perspectiva deste autor, poderia se constituir como uma estratégia para estabelecer um olhar mais amplo e mais crítico sobre determinadas temáticas, muito embora contrarie, à primeira vista, alguns dos princípios jornalísticos que regem a incessante busca pelo novo.

De acordo com o autor, a imprensa costuma receber as novidades "com o destaque de um invento, tão luminoso que ofusca a memória do passado". A compreensão dos fatos seria prejudicada, assim, porque a necessidade de surpreender não permite que sejam explorados os antecedentes ou os contextos em um sentido mais amplo. Este método de procedimento da imprensa pode ser resumido pela frase de David Helberstam, correspondente da Guerra do Vietnã, que dizia que "o problema é tentar cobrir uma coisa todos os dias como novidade, quando de fato a chave do problema é que tudo é uma consequência da Guerra Franco-Indochinesa, que já é parte da história" (apud SERVA, 2001: 110).

Essas críticas são pertinentes na medida em que apontam para o fato de que o tratamento histórico dos fenômenos pode ser bastante útil na elucidação de alguns fatos do presente que estão sendo retratados.

Podemos olhar a questão, no entanto, também sob um outro ponto de vista e, sem invalidar a postura anterior, pensarmos que esta construção do contexto, muito embora possa estar apoiada sobre dados objetivos do mundo, recebe determinados 
tratamentos narrativos durante a urdidura de enredo que, de um modo geral, funcionam como poderosos direcionadores e articuladores de sentido.

Isso é particularmente patente quando diz respeito a reportagens que tentam alinhavar a origem de determinadas temáticas. Marc Bloch chama a atenção para o fato de que, embora a noção de origem seja um conceito um tanto obscuro, há mesmo uma ideia, ligada ao senso comum, de que a origem é não apenas um início, mas sim, um início que explica. Ou pior ainda: um início que basta para explicar.

Essa imputação causal a partir de uma origem é um carregador de sentidos tão poderoso que o historiador coloca mesmo que ele é aplicado, na maioria das vezes, para explicar o presente apenas com a intenção de melhor justificar ou condenar. "De modo que em muitos casos o demônio das origens foi talvez apenas um avatar desse outro satânico inimigo da verdadeira história: a mania do julgamento" (BLOCH, 2001: 58).

Linguisticamente, uma abordagem possível a respeito desta temática pode ser alinhavada a partir da problemática dos pontos fortes da narrativa. Nesta perspectiva, a demarcação de um ponto inicial ou de um ponto de origem pode funcionar como um lugar de concentração ou de costura de sentidos para o texto. Vejamos como.

Como coloca Philippe Hamon (1977: 264), as situações de comunicação escritas diferem essencialmente das transmissões orais, na medida em que se trata de "uma comunicação, por definição, não reversível, descontextualizada, hermética e ambígua, que podemos definir como um cruzamento de ausências e de mal-entendidos (ausência do emissor e do contexto da emissão para o receptor, ausência simétrica do receptor e do contexto de recepção para o emissor, etc.)".

Sendo destinado a um público difuso e heterogêneo, para este autor, o texto escrito precisa impor algumas condições que possam assegurar "um mínimo de legibilidade", com o objetivo de "paliar sua ambiguidade fundamental por um deciframento compensatório" (HAMON, 1997: 265). E isso pode ser feito através da incorporação na própria mensagem de uma série de sinais, estruturas equacionais ou relacionais, de procedimentos estilísticos ou de momentos narrativos que tem como meta justamente a construção de um campo comum de entendimento e de comunicação.

Há, desta maneira, alguns momentos privilegiados nas narrativas que suturam seus significados: que costuram, de certa forma, as direções que devem ser tomadas pelos leitores e que contribuem, de forma decisiva, para a construção do sentido geral do texto. Esses momentos fortes funcionam como pontos nodais das estórias, na medida em que conseguem juntar uma série de sentidos ambivalentes e direcioná-los para um determinado tipo de cadeia significante. 
E é desta forma que determinadas expressões estereotipadas como "era uma vez" funcionam como demarcadores explícitos que indicam um gênero e introduzem uma enunciação organizadora. Este mesmo mecanismo, no entanto, também funciona em construções mais complexas. Os inícios das narrativas, os finais das estórias, as passagens de momentos narrativos para considerações de ordem descritiva: todos estes instantes funcionam como demarcadores de direcionamento e suturadores de sentido a serviço de determinados objetivos narrativos.

Dentro dessa lógica, as demarcações da origem de determinadas temáticas ou o estabelecimento de um ponto de início de um fenômeno não se constituem como meros dados objetivos acerca de uma questão. Na perspectiva da urdidura de enredo, ele pode ser entendido como um destes pontos fortes da narrativa, como um destes espaços destinados a organizar e direcionar os sentidos, como um dos mecanismos de desambiguação textual.

A origem como um dos pontos nodais de sentido da narrativa jornalística pode ser bem exemplificada quando analisamos as matérias que foram publicadas por ocasião do fim da obrigatoriedade do diploma de jornalista para o exercício da profissão e do desmembramento da chamada Lei de Imprensa. Podemos notar certa concordância no posicionamento dos quatro veículos analisados, que se mostraram favoráveis às duas decisões e as comemoraram como uma espécie de conquista profissional. Os argumentos utilizados para justificar o posicionamento também foram concordantes entre si: todas as revistas apelaram para a origem destas medidas, alocadas nos obscuros tempos da ditadura militar.

Segundo o editorial de Veja a respeito do fim da exigência do diploma:

O Supremo Tribunal Federal varreu da legislação brasileira mais uma herança da ditadura militar: a obrigatoriedade do diploma para quem exerce a profissão. (...) A obrigatoriedade do diploma foi impingida em 1969, auge da do regime de exceção instalado cinco anos antes, não para melhorar o jornalismo brasileiro, mas para controlar o acesso às redações de repórteres, editores e fotógrafos que eram considerados ameaçadores aos generais. Com a redemocratização do país, a norma passou a servir de instrumento de pressão política de sindicatos sobre jornais, revistas e emissoras independentes (VEJA, 24/06/2009: 12-13).

Este mesmo posicionamento estava presente em uma matéria sobre a liberdade de expressão publicada na semana anterior, onde se afirmava que "os jornalistas brasileiros trabalharam nas últimas quatro décadas sob a espada da Lei de Imprensa. Editada em 1967 pelos militares que governavam o país, a lei serviu como instrumento para intimidar repórteres e empresas de comunicação" (VEJA, 17/06/2009: 84). Na notícia que falava sobre a extinção da referida lei, este lugar comum é reafirmado e a 
revista coloca que "os onze ministros do Supremo Tribunal Federal encerraram na noite da última quinta-feira um capítulo da história do país. Por uma maioria de sete votos, o STF decidiu extinguir a Lei de Imprensa, um fóssil que remontava aos tempos da ditadura militar e cujo objetivo era silenciar jornais e revistas" (ESCOSTEGUY, 06/05/2009: 120):

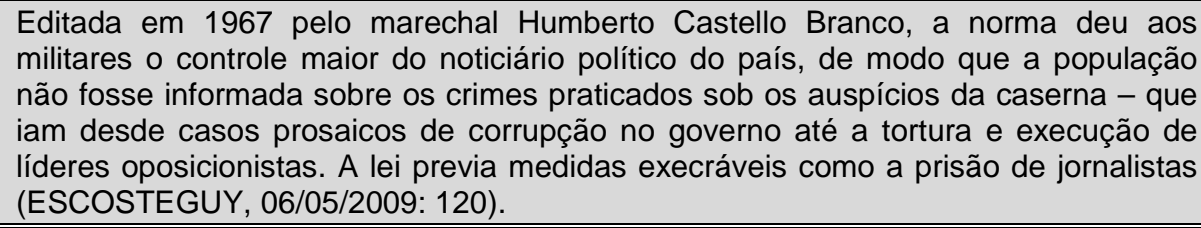
militares o controle maior do noticiário político do país, de modo que a população não fosse informada sobre os crimes praticados sob os auspícios da caserna - que iam desde casos prosaicos de corrupção no governo até a tortura e execução de líderes oposicionistas. A lei previa medidas execráveis como a prisão de jornalistas (ESCOSTEGUY, 06/05/2009: 120).

O tom da resposta de Carta Capital a cartas de leitores que reclamavam da baixa cobertura do caso do diploma na revista da semana anterior, não foi muito diferente. Segunda ela, a Carta Capital já havia manifestado inúmeras vezes sua opinião acerca deste assunto e "a derrubada da obrigatoriedade era esperada. A origem da questão está na ditadura, que inventou uma armadilha para tirar os excedentes das calçadas. (...) Era inevitável, porém, que mais cedo ou mais tarde uma lei de claro teor fascista se tornasse letra morta em um país que pretende ser democrático" (CARTA CAPITAL, 08/07/2009: 8).

No editorial de Época, embora a origem da obrigatoriedade do diploma não seja mencionada, a decisão é aplaudida nos seguintes termos:

O STF tomou neste ano duas decisões históricas, que merecem aplauso. A primeira foi, no final de maio, derrubar a Lei de Imprensa, uma herança da ditadura cujos principais artigos violam a garantia constitucional à liberdade de expressão. A segunda, na semana passada, foi eliminar, por oito votos contra um, a exigência de diploma para o exercício da profissão de jornalista. (...) De acordo com ele [Gilmar Mendes], a exigência do diploma é nociva por se tratar de uma tentativa de restringir algo constitucionalmente sagrado: a liberdade de expressão. (...) Muito obrigada, ministros do Supremo, pela decisão histórica. Valeu! (GUROVITZ, 22/06/2009: 8).

Ao atrelar as duas decisões tomadas pelo Supremo, a revista prolonga a origem da lei de imprensa á origem da obrigatoriedade do diploma como argumento básico de sua explanação. Sobre a Lei da Imprensa, inclusive, Época reforça a sua origem autoritária em uma outra reportagem publicada em Abril de 2009. Sobre isso, a revista noticiava, na linha fina, que "com um voto memorável do ministro Carlos Ayres Britto, o Supremo inicia o julgamento que deve revogar a Lei de Imprensa, resquício da ditadura". 
Curiosamente, essa menção à ditadura é insistentemente retomada durante a matéria. O lead da reportagem reforça que

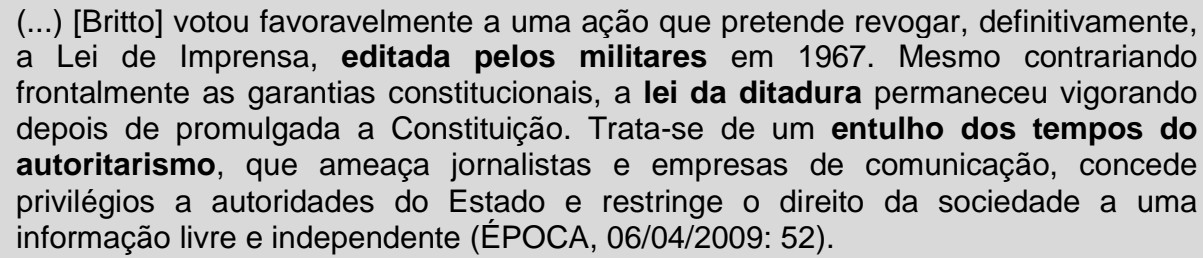

Mesmo em um quadro em que a reportagem mostra os dispositivos previstos na Lei, ela utiliza como título a expressão "Entulho da Ditadura" e coloca que "os dispositivos da Lei da Imprensa refletem o autoritarismo do regime militar. Estes foram suspensos pelo STF” (ÉPOCA, 06/04/2009: 52).

A única revista que se afastou um pouco deste tom festivo quanto ao fim do diploma para o exercício do jornalismo foi a IstoÉ, embora a origem da obrigatoriedade também seja mencionada. De acordo com ela, a decisão destrói a forma como a profissão foi organizada no Brasil nos últimos 40 anos, uma vez que a exigência vigorava desde 1969, pelo decreto-lei 972. "Na época, o governo militar pretendia inibir a liberdade de expressão, limitando o espaço nos veículos de comunicação àqueles que tivessem diploma específico. O tempo passou e a exigência do diploma deixou de ser um limitador da liberdade de expressão" (PATI e MARQUES, 24/06/2009: 80).

Em comentários sobre a Lei de Imprensa, no entanto, muito deste comedimento é relegado a um segundo plano. Segundo IstoÉ, "alguns esqueletos da ditadura militar continuam a circular por aí. Um deles é a Lei de Imprensa, que impõe limitações ao trabalho dos meios de comunicação. Só agora o Supremo Tribunal Federal começou a enterrar este resquício dos anos de chumbo" (COSTA, 08/04/2009: 44).

O que chama a atenção no direcionamento das revistas quanto a esta pauta é o fato de elas terem recorrido à origem da imposição destas medidas - origem esta que está ligada a um evento traumático do passado - como forma de justificar uma decisão do presente. A argumentação central não se estruturou em termos do mérito da proposta em si, mas sim, em torno de um suposto passado condenatório. Desta forma, pouco foi dito sobre o que teria mudado a respeito da temática depois do fim da ditadura militar.

A constante rememoração do instante em que a obrigatoriedade foi instituída carrega consigo mais do que uma mera informação: ela engendra mesmo um dos nós da narrativa, sendo responsáveis por uma série de determinações de sentido. Trata-se de um recurso argumentativo em que uma explicação para um fato atual é fornecida 
através da invocação de princípios que funcionam como leis pressupostas de funcionamento social e analogias de situação calcadas em explicações históricas (WHITE, 2008).

A evocação desta origem, portanto, é um poderoso direcionador de discursos na medida em que evoca, dentro de uma dada plataforma cultural, eventos que carregam uma série de predeterminações. Desta forma, ao repisar sobre a origem da obrigatoriedade do diploma, a narrativa jornalística já circunscreve quais são os tipos de generalizações que são permitidas serem feitas a respeito do fato presente, aliados aos tipos de conhecimentos que podemos ter dele. Mais do que isso, já predetermina também os tipos de projetos que são lícitos de serem propostos para mudar esse presente (WHITE, 2008).

É sobre este ponto de vista que, a partir de agora, podemos estudar as funções e sequências narrativas de origem que foram encontradas no corpus proposto. Além de funcionarem como pontos nodais de sentido, podemos entrever que, não raro, a demarcação dos pontos de origens é arbitrária e pode adquirir contornos explicativos, acusatórios ou míticos.

\section{A origem como ponto forte da narrativa:}

Muitas matérias que carregam esta marca de ter a origem na ditadura militar confirmam este efeito de sentido de um início que já está desde sempre maculado. No total do corpus, encontramos 102 matérias cuja origem da problemática retratada fazia remissão a este período histórico, o que corresponde a 6,21\% das matérias que tinham funções e sequências narrativas de origem.

Se levarmos em consideração as revistas individualmente, veremos que a Carta Capital é a publicação que mais se utiliza deste expediente, com um total de 10,29\% de todas as narrativas de origem publicadas de Janeiro a Dezembro (um total de 46 matérias). As porcentagens na revista Época ficam em torno de 6,11\% (25 matérias), a de Veja é de 4,25\% (com 18 matérias) e a de IstoÉ é de 3,59\% (com 13 matérias).

Neste sentido, em Carta Capital, podemos citar uma reportagem que criticava a policia carioca nos seguintes termos: "essa violência [praticada pelas forças policiais] é praticada à sombra de uma aberração jurídica, o 'Auto de Resistência' nascido no antigo Estado da Guanabara, em 1969, na esteira do Ato Institucional de número 5, a AI-5 da ditadura militar" (NEPOMUCENO, 19/08/2009: 27).

$\mathrm{Ou}$, ainda, na mesma publicação, em uma matéria que elogiava as tentativas de mudanças na Lei do Estrangeiro, colocava-se que "concebida nos moldes da doutrina da 
Segurança Nacional da ditadura, a Lei do Estrangeiro (6.815, de 1980) restringe atividades remuneradas, cria obstáculos à concessão de vistos de permanência e proíbe a organização e manifestação política” (MARTINS, 08/07/2009: 37). Ou, por fim, ao desmerecer uma lei que o delegado Protógenes Queiroz (um personagem bastante bem quisto pela publicação) havia sido acusado de violar: "Protógenes foi acusado de ter infringido uma lei de 1966, imperiosa para a ditadura de então, que proíbe atividades político-partidárias de servidores da corporação" (FORTES, 18/11/2009: 25-26).

Os posicionamentos da revista em cada uma das matérias são inseridos e articulados, desta forma, na demarcação da origem das medidas que teriam sido violadas ou modificadas. Ao estabelecer a origem, colocando as medidas como filhas da ditadura, uma série de valores sociais consensuais são mobilizados e determinam a demarcação das referidas leis como leis mortas.

É no nível dos implícitos da linguagem que esta suposta origem condenatória alinhava e prende alguns encadeamentos de sentido que se querem confirmados. E, assim como em outros exemplos citados no presente trabalho, a eficácia desta demarcação depende de um acordo já pré-estabelecido entre o leitor e o jornalista que dividem uma determinada plataforma cultural comum: "do princípio ao fim, a análise da argumentação versa sobre o que é presumidamente admitido pelos ouvintes" (PERELMAN e OLBRECHTS-TYTECA, 1996: 70).

O funcionamento retórico desta demarcação de um início condenatório na ditadura militar pode ser explicado nestes exemplos - assim também como nas reportagens sobre a Lei de Imprensa e o fim da obrigatoriedade do diploma para o exercício da profissão do jornalista - a partir da construção de uma correlação de coexistência entre a origem e o presente, estabelecida a partir de uma ligação simbólica.

O símbolo, de uma forma geral, é um elemento linguístico cuja característica, segundo Pierce (2000), é ser sempre regido por algum tipo de convenção e se referir a ideias gerais. Assim, como explica Kristeva (1984: 29), ele “opera com unidades simbólicas que são unidades de restrição em relação aos universais simbolizados (o 'heroísmo', a 'coragem', a ‘nobreza', a ‘virtude', o ‘medo', a 'traição', etc.)”. A autora (1984: 36) opõe o símbolo ao signo de forma que o signo "não remete para uma realidade única e singular, mas evoca um conjunto de imagens e ideias a elas associadas".

Ele é caracterizado por apresentar uma relação de participação entre ele e o que ele evoca, de maneira que isso se processa não como uma analogia, mas sim, como uma 
participação mútua quase-mágica. Isso porque ela acarreta, de uma forma geral, uma transferência entre o símbolo e o simbolizado.

Como explicam Perelman e Olbrechts-Tyteca (1996: 378), "quando a cruz, a bandeira, a pessoa do rei são encaradas como símbolos do cristianismo, da pátria, do Estado, essas realidades despertam um amor ou um ódio, uma veneração ou um desprezo, que seriam incompreensíveis e ridículos se, com o seu caráter representativo, não estivesse relacionado um vínculo de participação".

As ligações emocionais desempenham um papel importante neste tipo de recurso argumentativo e, é importante ressaltar, que a sua utilização não garante a eficácia persuasiva na medida em que os valores em jogo devem ser tomados como consensuais:

A precariedade da ligação simbólica, juntada ao seu poder evocador e à sua força emotiva, deve-se decerto ao fato de não estar muito sujeita à justificação. Os símbolos exercem uma ação inegável sobre aqueles que reconhecem a ligação simbólica, mas não exercem nenhuma sobre os outros; eles são característicos de uma cultura particular, mas não podem ter serventia para o auditório universal, o que lhes confirma o aspecto irracional" (PERELMAN e OLBRECHTS-TYTECA, 1996: 382).

Ele é formado, muitas vezes, pela utilização de meros indícios ou detalhes que evocam uma série de pressupostos em uma plataforma cultural comum.

É assim que “certos indícios podem tornar-se simbólicos de uma situação, de uma maneira de viver, de uma classe social, como o fato de possuir um automóvel de certa marca ou usar uma cartola". Da mesma forma, "se um indivíduo, membro de um grupo, tornou-se símbolo deste, seu comportamento será considerado mais importante, porque mais representativo, do que o de outros membros do mesmo grupo" (PERELMAN e OLBRECHTS-TYTECA, 1996: 380).

Desta forma, vemos que a ligação de coexistência simbólica constrói um campo comum de tal forma que tudo o que diz respeito ao símbolo diz respeito também ao simbolizado. Se tivermos que o leão simboliza a coragem, o homem que for descrito como um leão partilhará das características pressupostas deste animal.

Isso posto, podemos pensar que a ditadura militar funciona como uma espécie de símbolo nas matérias citadas. A ligação simbólica estabelecida entre a origem das problemáticas discutidas e os seus desdobramentos atuais, garante a mobilização de uma série de subentendidos relacionados a arbitrariedades, a autoritarismos e a uma imensa gama de outras características negativas ligadas àquele período histórico.

Aplicado ao esquema proposto por Ducrot, temos o seguinte: 


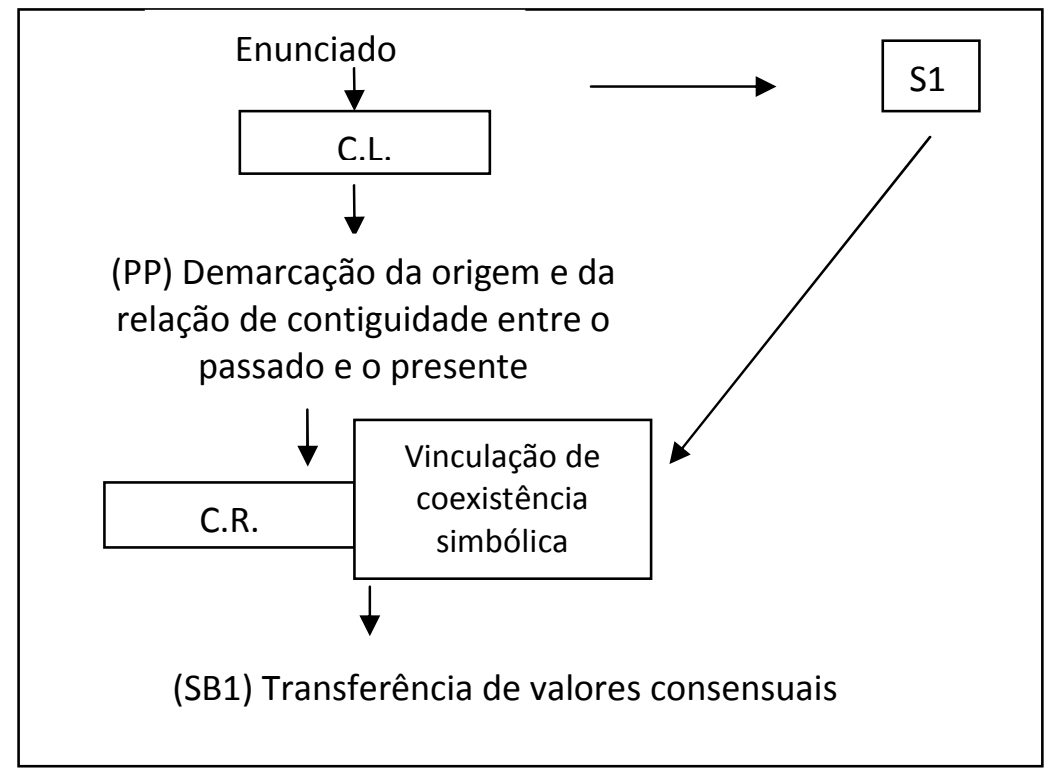

A questão da demarcação da origem de uma problemática possui, ainda, alguns elementos complicadores que precisam ser analisados. Eles dizem respeito ao exame do fato de que demarcar o início ou os pontos fundadores de uma determinada temática é, por vezes, um procedimento arbitrário. A origem de uma determinada questão não é um ponto intrínseco da estória que está sendo contada e para um grande número de problemáticas poderíamos demarcar um sem número de origens ou de inícios possíveis, dependendo da forma como queiramos conduzir nosso enredo. Já exploramos a ideia de que a origem é um dos nós fundamentais da intriga e determina e série de efeitos de sentido a serem explorados. Queremos investigar agora como a origem muda, portanto, em função do sentido que se quer confirmado.

Uma pauta interessante, neste sentido, foram as matérias publicadas a respeito da decisão do governador do Rio de Janeiro, Sérgio Cabral, em construir muros em torno das favelas cariocas com o objetivo de frear a expansão das moradias irregulares. A revista $I s t o E$ explica as origens deste fenômeno nos seguintes termos:

O descontrole sobre as construções irregulares tem explicação histórica. Desde os anos 1980, quando o governador Leonel Brizola chegou ao poder no Estado, a palavra 'remoção' foi excluída do vocabulário político carioca em nome da popularidade nas urnas. Brizola conteve a truculência policial nos morros, mas incentivou a multiplicação dos barracos, inclusive com a concessão de lotes em várias regiões do Estado. Seus sucessores assistiram passivos ao crescimento desordenado da favelização da cidade (MAGRO, 22/04/2009: 51).

A origem do descontrole no crescimento das favelas também é alocada no governo Brizola pela revista Veja. Segundo a publicação, o estímulo à ocupação 
irregular na cidade data da década de 1980, quando Brizola "defendeu a manutenção dos barracos e concedeu indistintamente títulos de propriedade a favelados, numa política movida pelo espírito nefasto de que favela não é problema, é solução. A partir daí, a favelização ganhou tamanho impulso que se transformou num negócio lucrativo para aproveitadores em geral e políticos em particular" (SOARES, 22/04/2009: 68).

Os fatos evocados pela revista Época para explicar o problema, são um pouco diferentes. Esta revista cita uma gama maior de fatos históricos relacionados às favelas cariocas - nomeadamente a comparação com outros projetos que tentaram lidar com este tipo de problema como as remoções realizadas pelos governadores Carlos Lacerda e Negrão de Lima - e aloca uma das origens da ineficácia dos governantes cariocas em conter a expansão das favelas em um período anterior aos citados nas reportagens de Veja e IstoÉ: “a fracassada remoção dos anos 1960 gerou novas favelas, que viraram células de crescimento para outras comunidades" (FERNANDES, 18/05/2009: 54).

Não é especificamente a política levada a cabo por Brizola (que nem ao menos é citado) que é o motivo ou a origem principal do caos atual, segundo a revista, mas sim, o fracasso de uma série de políticas de remoção. De acordo com a reportagem: "as poucas iniciativas para amenizar o problema fracassaram e, por ironia, acabaram criando mais favelas. Entre 1903 e 1905, a administração Pereira Passos removeu 20 mil pessoas que viviam na área central da cidade para os subúrbios" (FERNANDES, 18/05/2009: 56).

Embora a temática tratada seja essencialmente a mesma nas três reportagens citadas, ou seja, o descontrole do poder público na questão das favelas, as origens do problema aludido diferem em função do posicionamento que se quer confirmado pelo veículo. IstoÉ e Veja, ao defenderem a postura de Cabral de coibir o crescimento nas favelas, alocam a origem do descontrole em uma política pública específica que estimulava a ocupação destes lugares. Com um posicionamento diferente, a reportagem de Época marca um ponto inicial do problema mais antigo e relacionado a uma gama diferente de fatos, que dizem respeito às políticas de contenção.

Poder dizer que a origem do descontrole - este é o ponto consensual que une as duas abordagens - está em uma política pública de estímulo ou está em uma política pública de contenção mostram o quanto a demarcação de um momento inicial pode ser arbitrária. De uma maneira geral, os dois pontos podem ser considerados corretos. A reportagem enfatizará, contudo, aquele que melhor se adequar ao ponto de vista que se quer confirmado. 
A transformação da crônica (ou da mera sequência dos fatos) em estória implica exatamente esta operação de demarcar os motivos iniciais, os motivos transitórios e os motivos conclusivos de determinados processos sociais e organizá-los em função de uma determinada estrutura de enredo. Como coloca Hayden White (2008: 22), "a rigor, as crônicas tem final em aberto. Em princípio não tem inícios; simplesmente 'começam' quando o cronista passa a registrar os eventos. E não tem pontos culminantes, nem resoluções; podem continuar indefinidamente". As estórias não. Estas precisam ter "uma forma discernível (mesmo quando esta forma é a imagem de um estado de caos) que separa os eventos nela contidos dos outros eventos que poderiam aparecer numa crônica abrangente dos anos cobertos em seus desdobramentos".

Ao lidar com estórias, o jornalismo precisa efetuar esta passagem ou, em outras palavras, estabelecer uma urdidura de enredo e isto significa, de uma maneira geral, encontrar estas "estórias que jazem nas crônicas". E isso implica um grande grau de invenção por parte do jornalista - invenção esta que não implica uma "mentira" ou uma "distorção dos fatos", mas apenas uma forma específica de se contar uma estória em função de um determinado posicionamento e de uma forma específica de se enxergar o mundo.

Demarcar determinado evento como a origem de uma problemática ou como o motivo inicial de um processo social é um problema, portanto, que ultrapassa uma discussão que se coloque apenas em termos de "verdadeiro" ou "falso". E isso porque "a morte do rei pode ser um começo, um final, ou simplesmente um evento de transição em três estórias diferentes". E assim, “o mesmo evento pode ser útil como um tipo diferente de elemento de muitas histórias diferentes, dependendo da função que lhe é atribuída numa caracterização motívica específica do conjunto a que ele pertence" (WHITE, 2008: 22).

A demarcação de um ponto de origem, portanto, é uma fase especialmente delicada da narrativa uma vez que ela não se apresenta como um dado meramente objetivo acerca do problema e a sua demarcação é, muitas vezes, um procedimento arbitrário ligado às possibilidades de urdidura de enredo. Em outras palavras, para uma mesma problemática, poderíamos demarcar muitas origens, sem que elas fossem mutuamente excludentes ou sem que pudessem, individualmente, serem consideradas "erradas" ou "inadequadas".

Nas próprias reportagens apresentadas acerca das favelas, outros pontos ainda poderiam ter sido escolhidos como marcos para a origem do descontrole do poder público sobre as favelas e isso pode ser facilmente encontrado na literatura sobre o 
tema. Como explica Flávia Ribeiro (2009), por exemplo, “no Rio, os primeiros registros de pessoas morando de modo improvisado em morros são da década de 1860. Cerca de 20 anos depois, já era possível ver conjuntos de famílias vivendo em casebres de madeira nos morros de Santo Antônio, do Castelo e do Senado, no centro da cidade". As reportagens poderiam fazer referência, ainda, ao que a pesquisadora Licia Valladares (2005: 36) chama de "mito fundador das favelas", que diz respeito ao estabelecimento de ex-soldados que combateram na Guerra de Canudos no morro da Providência, no Rio de Janeiro, no final do século XIX. Segundo a autora, a partir do imaginário já consolidado por Euclides da Cunha, neste ponto histórico, "estava descoberta a favela (...) e lançadas as bases necessárias para sua transformação em problema".

Ribeiro (2009) esmiúça, ainda, outros pontos como, por exemplo, o fato de que “em 1922, o poder público removeu grande parte das pessoas que viviam nos morros da Providência, Santo Antônio e Gávea-Leblon. No fim dos anos 20, o francês Alfred Agache propôs um projeto urbanístico para o Rio. Nele não havia espaço para as favelas, consideradas um problema 'sob o ponto de vista da ordem social, da segurança, da higiene, sem falar da estética'". Este procedimento ainda se manteve na década seguinte e, "em 1937, o Código de Obras da cidade citou as favelas como uma 'aberração urbana' e propôs sua eliminação, proibindo a construção de novos barracos. Mais do que isso, o Código proibia melhorias nos morros já ocupados. Em vez de encarar a questão das favelas, mais uma vez os governantes resolviam apenas tentar fazer com que elas desaparecessem".

Diversos outros marcos históricos poderiam ter sido postos como a origem do problema, sem que nenhum deles pudesse ser considerado errado. De fato, todos estes pontos marcam uma espécie de diferença ou de ruptura com o que veio antes e o descontrole das favelas - em si um tema um tanto abstrato - poderia eleger qualquer um deles como ponto de origem. Uma matéria que quisesse tratar a política do governador Cabral como parte de um preconceito em relação aos moradores da favela poderia eleger, de bom grado, qualquer um destes pontos listados acima como a marcação de uma origem, sem que isso se configurasse como uma manipulação dos fatos.

A arbitrariedade da marcação do ponto inicial também fica clara em editoriais como o de Mino Carta em que ele coloca que a "origem da perene desgraça nacional" é a escravidão. Segundo ele "seus efeitos perduram implacavelmente", uma vez que "a escravidão representou o mais autêntico estágio da educação cultural do país. No povão deixou as marcas do chicote. À minoria, ensinou prepotência, ganância, desmando. Impunidade. Arrogância" (CARTA, 11/03/2009: 22). 
A partir desta marcação inicial, todas as explicações são articuladas em função dela. Assim, o editor pode afirmar que "o jornalismo brasileiro, desde os começos, serve a este poder nascido na casa-grande, por ter a mesma, exata origem" (CARTA, 11/03/2009: 22).

Neste caso, a arbitrariedade da marcação do ponto de início pode estar relacionada ao estabelecimento de origens concretas para problemas abstratos. $\mathrm{O}$ ancoramento da arrogância da imprensa brasileira à escravidão funciona, neste caso, mais como um elemento retórico do que como uma demarcação efetiva. O recurso a um evento traumático funciona como um símbolo forte e, como nos exemplos anteriores, estabelece esta ligação quase-mágica envolvida nas correlações de coexistência entre a origem e o presente a partir de uma ligação simbólica. Aqui também há uma espécie de transferência entre o símbolo e o simbolizado, de forma que as características negativas presentes na escravidão sejam transferidas para o processo social retratado.

Isso nos remete, contudo, a um outro ponto fundamental. Ao atrelar a arrogância da imprensa à simbologia da escravidão, textos jornalísticos como este também remetem a um outro aspecto importante no que concerne às funções e sequências narrativas de origem: a demarcação do ponto inicial, além de engendrar alguns nós de sentido, não raro também ganha uma tonalidade explicativa e delimitam os entendimentos possíveis em torno de um tema.

É justamente em função desta origem (a escravidão) que toda a explicação a respeito do comportamento dos donos das mídias se estrutura. É por causa dela que, segundo o editorial de Carta, a Folha de S. Paulo expôs "a peculiar ideia da 'ditabranda', e da agressão cometida pelo jornal contra dois leitores indignados do porte de Maria Victoria Benevides e Fábio Konder Comparato". É por causa dela que "basta que no horizonte se delineiem tímidas nuvens remotamente ameaçadoras à tranquilidade da minoria e os barões midiáticos formam a mais compacta das alianças para sustar o perigo" (CARTA, 11/03/2009: 22). Mais do que um nó de sentido para o texto, portanto, a questão da demarcação de um início se torna um dos nós explicativos a partir do qual irá se sustentar a análise argumentativa do texto.

Essa questão ganha alguns contornos dramáticos na coluna de Leonardo Attuch, na $I s t o E ́$ de 14/01/2009, quando o colunista realoca a origem da guerra entre os israelenses e os palestinos, colocando que "os homens que criaram Israel também já foram rotulados como terroristas". Para sustentar a sua afirmação, ele recorre ao Haganá que, segundo ele, era "o nome de uma organização paramilitar judaica que combatia a ocupação britânica na Palestina, que durou de 1920 a 1948”. 
O colunista continua afirmando que “dela, nasceu o Irgun, a 'organização', que pregava a luta armada como a única alternativa para a criação do Estado de Israel. No seu ataque mais ousado, em abril de 1946, a Irgun explodiu o hotel Rei Davi, em Jerusalém, matando 91 civis".

A existência destes grupos é ligada ao atual confronto entre árabes e judeus, nas passagens a seguir. Em um primeiro momento, Attuch afirma que "vários dirigentes do Estado judaico tiveram vínculos estreitos com organizações sionistas de extrema direita, que participaram de atos de terror" e que "da Irgun, também fizeram parte os pais da atual chanceler de Israel, Tzipi Livni, que é a face visível e uma das vozes do comando do massacre contra palestinos na Faixa de Gaza". Em seguida, ele coloca que "em 1948, para que surgisse Israel, dois fatores foram decisivos: a vergonhosa memória do Holocausto e a combatividade do povo judaico. Assustados com o 'terror' de organizações como o Irgun, os ingleses bateram em retirada de Jerusalém e 700 mil árabes perderam suas casas, tornando-se refugiados" (ATTUCH, 14/01/2009: 79).

O que Attuch faz, neste último trecho é realocar o ponto de início do confronto entre árabes e palestinos. Ao passo que as demais revistas colocavam a fundação do Estado de Israel em termos muito mais suaves ${ }^{59}$, Attuch reengendra a questão ao colocar como origem do conflito não só a violência sofrida pelos judeus durante o Holocausto, mas também (ou principalmente) as demonstrações de violência que partiram deles. $\mathrm{E}$ não se trata, neste caso, de uma violência "legalizada", de "Estado" ou "de guerra", mas sim, uma violência terrorista, em termos muito parecidos aos usados quando se retrata as ações do outro lado do conflito, o Hamas.

\footnotetext{
${ }^{59}$ Em Veja, por exemplo, colocava-se que "as razões de cada lado são conhecidas. A criação de Israel decorreu da perseguição dos judeus na Europa e foi legitimada pelo mais hediondo dos crimes, o genocídio cometido pela Alemanha nazista. Quem pode negar aos judeus o direito de ter um país forte e protegido, e, numa espécie de justiça histórica, no mesmo lugar onde havia existido dois milênios antes? Ao ser erigido, no entanto, o estado de Israel desencadeou a privação dos habitantes árabes, que perderam casas, terras e identidade. Quem pode negar a injustiça histórica cometida contra os palestinos? Ou a sua legítima aspiração a um estado independente?" (GRYZINSKI, 07/01/2009: 53). Em Época, explica-se que "o Império Otomano controlou a Palestina por séculos, até ruir após a Primeira Guerra Mundial (1914-1918). Coube à Inglaterra administrar a região. Incapazes de sufocar os levantes palestinos e judaicos por maior autonomia, os britânicos devolveram a região em 1947 para o controle da ONU, que propôs a partilha do território em dois Estados: um judaico e um palestino. Mais organizados, os sionistas proclamaram a independência de Israel em 1948" (MACHADO, 12/01/2009: 82). É importante notar que, embora faça referência ao mesmo fato histórico que Attuch, a reportagem de Época não faz menção a atos ou a organizações terroristas israelenses, o que contribui, de forma acentuada, para a produção de um determinado sentido. Na própria reportagem da revista IstoÉ, isso não é citado e as origens do confronto são postas nos seguintes termos: "1948: a ONU aprova a partilha da Palestina então administrada pelos britânicos, em dois Estados: um judeu e outro palestino. Os britânicos se retiram, mas a Liga Árabe (Egito, Jordânia, Síria e Líbano) não reconhece Israel e ataca o novo Estado. Os árabes são derrotados e Israel ocupa grande parte do que seria o Estado palestino" (VILLAMÉA, 14/01/2009: 74).
} 
Com a mudança do nó narrativo posto pela origem, toda a explicação em torno do conflito também é modificada. Os sentidos articulados são inteiramente outros, neste caso. As relações entre as vítimas e os culpados são realocadas, bem como o julgamento das soluções postas em pauta pelas partes em conflito.

O texto de Attuch opera mesmo uma modificação total dos pressupostos e dos subentendidos em jogo nas construções de sentido em torno do conflito entre palestinos e israelenses ao modificar apenas um dos elementos narrativos articulados (em comparação com o tratamento dado em outros textos da imprensa): esse elemento é justamente a origem do confronto.

A forma como a origem articula as explicações possíveis em torno de um tema pode ser observada, com contornos diversos, em outros textos noticiosos.

Em uma reportagem de Carta Capital, é a origem dos eleitores que apoiam o Yisrael Beiteinu, partido de extrema direita liderado por Avigdor Lieberman nas eleições israelenses, que explica o fato de ele se constituir como a terceira força política do país e que estrutura a argumentação da revista em torno das questões polêmicas defendidas por ele. Segundo a matéria, "sua base está no 1,25 milhão de imigrantes russos dos anos 80 e 90, com alto grau de instrução, não religiosos e mal inseridos na sociedade israelense. Muitos nem sequer se consideram judeus: apenas aproveitaram a oportunidade de fugir do caos da Rússia pós-socialista provando ter pelo menos um avô judeu para obter a cidadania, como permite a lei israelense. Alguns desses imigrantes chegaram a criar gangues neonazistas em Israel, por paradoxal que pareça" (COSTA, 18/02/2009: 41).

Nesta matéria podemos notar claramente que a suposta origem dos eleitores deste partido - que, na construção feita pela reportagem é bastante problemático por razão das causas que defende ${ }^{60}$ - adquire alguns contornos essencialistas que, não raro, ganha tonalidades preconceituosas. As características negativas imputadas aos membros que formam a base de sustentação do partido são estendidas, dentro desta construção narrativa, às medidas pouco consensuais tomadas por seus integrantes. Assim, a correlação de coexistência simbólica caracterizada pela transferência do símbolo para o

\footnotetext{
${ }^{60}$ Entre as causas polêmicas que este partido prega, por exemplo, podemos citar que, segundo a matéria, "se depender do Yisrael Beiteinu - abreviação de "Israel é Nosso Lar. Palestina é o Deles" (lema oficial do partido) em hebraico, manter a cidadania exigirá um juramento de lealdade ao Estado judeu e seus símbolos. O partido está disposto a apoiar um Estado palestino e até a ceder um pequeno território de maioria árabe dentro de Israel, mas em troca da cassação da cidadania e expulsão de 90\% dos árabes" (COSTA, 18/02/2009: 41). A revista descreve esta medida como "inédita até mesmo em estados totalitários".
} 
simbolizado, adquire os contornos, em um contexto político, de uma transmissão do representado (no caso, o eleitor) para os seus representantes.

O curioso, nesta reportagem, é que estas características negativas que marcam este suposto eleitor do Yisrael Beiteinu (e que, consequentemente, passam a ser incorporadas pelo próprio partido) não são dadas a partir de pesquisas de opinião a respeito das questões que os seus políticos defendem, nem a partir de nenhum outro aspecto ligado às ações do presente. É a origem deste tipo de eleitor que explica, em grande medida, por que o partido é como é.

Muito embora este tipo de matéria não recorra a um símbolo forte (como a "escravidão" ou a "ditadura" dos exemplos anteriores), a coesão simbólica é garantida pelos subentendidos que são mobilizados ao se contar a história daqueles que usualmente votam no partido. Descritos como imigrantes que aportaram em Israel a partir de uma determinada conjuntura histórica (não ligada ás causas judaicas, mas a problemas de ordem diversa) e utilizando-se de artifícios oportunistas para a obtenção de sua permanência, um conjunto de subentendidos é mobilizado para que características negativas sejam imputadas a este tipo de eleitor. Ele é reforçado ainda, por determinadas marcas de pressuposição - como "mal inseridos", "aproveitaram a oportunidade" ou "chegaram a criar gangues neonazistas" - que reforçam ou confirmam essas características ruins e contribuem para a construção do sentido do texto.

Essa formação discursiva se torna ainda mais significativa no trecho seguinte, em que essas características esboçadas na origem de um grupo deixam a esfera da interpretação e ganham tonalidades relacionadas à previsão do futuro. Isso porque, logo em seguida ao trecho citado, a reportagem acrescenta: "No que se torna uma ultradireita radical não motivada pela religião ou pela preservação das tradições? Na Europa, quando a modernidade esvaziou o tradicionalismo religioso, eventualmente antijudeu, seu espaço à direita foi ocupado pelo racismo e pelo fascismo". E completa que "a direita israelense também segue o caminho do racismo e da lealdade incondicional ao Estado" (COSTA, 18/02/2009: 41).

O estabelecimento deste tipo de comparação histórica só é possível por causa da suposta origem estabelecida anteriormente. Se as comparações históricas frequentemente estabelecem uma relação de solidariedade entre o presente e o passado de tal forma que eles são tomados como análogos (o que não raro inclui alguns exercícios de futurologia), como colocamos anteriormente, isto só foi possível nesta reportagem porque a origem do grupo descrito estabeleceu que a sua essência estava relacionada ao fato de que ele não era "motivado pela religião ou pela preservação das 
tradições". É a partir desta correlação de coexistência simbólica previamente estabelecida que se estrutura o nó da narrativa.

Se nesta reportagem, especificamente, as características demarcadas já na origem de um grupo ganham uma conotação negativa, em outras, ela pode servir mesmo como uma característica de distinção e formar a base para as explicações mais prosaicas. Neste sentido, mesmo o sucesso de determinados produtos culturais pode ser explicado a partir de um suposto apelo às origens e é isso que a revista Veja faz ao explanar por que o filme Ele não Está Tão a Fim de Você, lançado de Março de 2009, foi um sucesso de bilheteria. Segundo a reportagem,

Mais surpreendente ainda é que este resultado positivo se deve em parte à matériaprima da qual o filme se origina. O ensinamento moral está no genoma da produção cultural americana, das jeremiadas - os longos textos de exortação produzidos pelos puritanos - e da Declaração de Independência à corrente de autoajuda, oficialmente inaugurada na década de $1930 \mathrm{com}$ o perene Como Fazer Amigos e Influenciar Pessoas (BOSCOV, 25/03/2009: 138).

A origem de um grupo, por vezes, ganha cores ainda mais difusas e demonstram uma tentativa de reafirmação de valores associados a uma determinada cultura. Eles se assemelham, em algumas ocasiões, a tentativas mais ou menos conscientes de historicização de mitos. Este mecanismo fica muito claro em uma matéria a respeito do empreendedorismo feita pela revista The Economist e republicada por Carta Capital. De acordo com a reportagem, os Estados Unidos tiveram uma vantagem econômica competitiva uma vez que foi o primeiro país "a abandonar o capitalismo administrado pela variedade empreendedora". Este espírito de liderança e esta vontade de se aventurar na realização de tarefas difíceis e fora do comum, ou seja, uma atitude altamente empreendedora dos norte-americanos é explicada a partir das seguintes bases históricas que formaram a nação:

Os EUA realizaram esta mudança na economia de forma mais fácil, porque a inovação está enraizada em sua história. O país foi fundado e colonizado por aventureiros dispostos a sacrificar velhas certezas por novas oportunidades. Os alunos das escolas americanas são criados com histórias sobre inventores, como Benjamin Franklin e Thomas Edison. Empreendedores como Andrew Carnegie e Henry Ford são celebrados em monumentos (CARTA CAPITAL, 01/04/2009: 53).

Não só as revistas norte-americanas, como a The Economist, apelam para este passado mítico historicizado como forma de explicar determinados eventos ou determinadas tendências do tempo presente. Roberto Pompeu de Toledo, em sua coluna da revista Veja, ao argumentar como a estabilidade institucional dos Estados Unidos é o 
segredo deste país que o permite dar saltos em direção à renovação, também apela para esta origem fundadora da índole do norte-americano, em outros termos. Segundo o colunista:

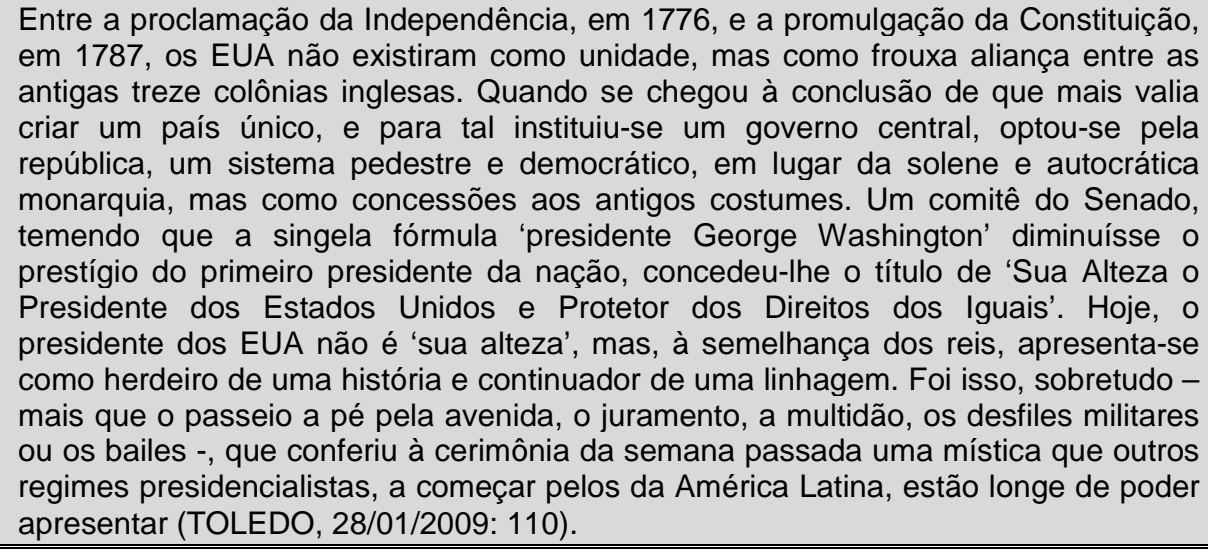
em 1787, os EUA não existiram como unidade, mas como frouxa aliança entre as antigas treze colônias inglesas. Quando se chegou à conclusão de que mais valia criar um país único, e para tal instituiu-se um governo central, optou-se pela república, um sistema pedestre e democrático, em lugar da solene e autocrática monarquia, mas como concessões aos antigos costumes. Um comitê do Senado, temendo que a singela fórmula 'presidente George Washington' diminuísse o prestígio do primeiro presidente da nação, concedeu-lhe o título de 'Sua Alteza o Presidente dos Estados Unidos e Protetor dos Direitos dos Iguais'. Hoje, o presidente dos EUA não é 'sua alteza', mas, à semelhança dos reis, apresenta-se como herdeiro de uma história e continuador de uma linhagem. Foi isso, sobretudo mais que o passeio a pé pela avenida, o juramento, a multidão, os desfiles militares ou os bailes -, que conferiu à cerimônia da semana passada uma mística que outros regimes presidencialistas, a começar pelos da América Latina, estão longe de poder apresentar (TOLEDO, 28/01/2009: 110).

Em todas essas reportagens, um mesmo elemento comum é evocado: a origem do norte americano como explicação para seus comportamentos atuais mais típicos. Seja o gosto por um determinado gênero cinematográfico, seja a atitude empreendedora, seja o estabelecimento da regularidade institucional, todos esses modos de agir são explicados com base naqueles elementos que estavam na base e na formação do povo norte americano. Mais do que isso: as características difusas e abstratas ganham uma concretude ao serem relacionadas com eventos consistentes e palpáveis, postos na origem do grupo em questão.

Essa promiscuidade existente entre as narrativas históricas e os diversos projetos de nacionalismo já foi apontada por diversos autores. É neste sentido que podemos entender a máxima de Ernest Renan que de "entender mal a História é parte essencial de se tornar nação" (apud HOBSBAWM, 2005: 38), ou ainda, a asserção de Hobsbawm de que "a história é a matéria-prima para as ideologias nacionalistas ou étnicas ou fundamentalistas, tal como as papoulas são a matéria-prima para o vício da heroína". E isso porque "o passado é um elemento essencial, talvez $o$ essencial nessas ideologias. Se não há um passado satisfatório, sempre é possível inventá-lo" (HOBSBAWM, 2005: 17).

Fenômeno surgido no século XIX, segundo Le Goff (2003), a justificação dos diversos tipos de nacionalismo por meio da história é alimentada por dois novos fatores político-sociais surgidos neste período: as noções burguesas de classe e democracia e o sentimento nacional, que se tornam as principais temáticas do período. Se desde a Idade 
Média já existia uma ideia de nação, é durante a Revolução Francesa, porém, que ela toma o formato de uma religião da pátria ${ }^{61}$.

Os antigos laços conferidos, por exemplo, pela legitimidade dos reinos dinásticos ou, ainda, pela religião como forma de coesão social, começam a perder espaço neste novo contexto e "a partir desse momento, o que agrega as comunidades, para além do conhecimento face-a-face, é a ideia de que partilham uma história, cultura, valores, território e fundamentos de organização administrativa" (CUNHA, 2007: 189).

Uma vez que estes novos laços passam a ter como base de sustentação a forma como uma coletividade enxerga a si própria em relação aos outros grupos, a reivindicação de uma história comum "pode tomar características essencialistas ${ }^{62}$ ao atribuírem a um acontecimento do passado histórico a sua origem e as características determinantes da identidade, entendidas como imutáveis e integrantes de uma mesma origem biológica". E assim, "esta perspectiva essencialista tende a ser suportada por sistemas classificatórios e marcações simbólicas poderosas que acompanham, normalmente, a emergência de formas conservadoras e violentas de nacionalismo" (CUNHA, 2007: 191).

É a partir destas premissas que Pollak (1992: 204) coloca que a memória é um elemento fundamental na constituição das identidades "na medida em que ela é também um fator extremamente importante do sentimento de continuidade e de coerência de uma pessoa ou de um grupo em sua reconstrução de si”. Além disso, o autor enfatiza que a importância da correlação memória-identidade faz com elas possam ser constantemente manipuladas e/ou negociadas e, desta forma, não podem ser encaradas como fenômenos que possam ser compreendidos como essências de uma pessoa ou de um grupo, muito embora muitas vezes elas sejam tratadas desta forma.

\footnotetext{
${ }^{61}$ A obra Histoire de France, de Ernest Lavisse, publicada entre 1900 e 1912, é um bom exemplo deste fenômeno, na medida em que propunha um modelo de ensino de História nos seguintes termos: "Cabe ao ensino da história o glorioso dever de fazer amar e compreender a pátria (...) nossos antepassados gauleses e as florestas com druidas, Carlos Martel em Poitiers, Rolando em Roncesvaux, Godofredo de Bulhão em Jerusalém, Joana D'Arc, todos os nossos heróis do passado, reais ou lendários (...). Se o estudante não levar consigo uma recordação viva das nossas glórias nacionais, se não souber que nossos antepassados combateram em mil campos de batalha, por mil causas, se não aprender o que custou, em sangue e esforços, construir a unidade da nossa pátria e libertar do caos das nossas envelhecidas instituições as leis sagradas que nos tornaram livres, se não vier a ser um cidadão compenetrado de seus deveres e um soldado que ama a sua bandeira, então o professor perdeu o seu tempo" (apud LE GOFF, 2003: 75).

${ }^{62}$ Por "essência", estamos nos referindo aqui ao seguinte aspecto: "os acontecimentos caracterizam uma época, as obras, um estilo, as instituições, um regime; mesmo os comportamentos e a maneira de ser dos homens podem ser explicados não só pelo fato de pertencerem a um grupo, mas também pela época ou pelo regime com que se relacionam: falar do homem de Idade Média ou de um comportamento capitalista é tentar mostrar como esse homem e esse comportamento participam de uma essência e a expressam, e como, por seu turno, permitem caracterizá-la (PERELMAN e Olbrechts-Tyteca, 1996: 372).
} 
Em consonância com isso, Hobsbawm coloca que, dentro de um escopo geral, a manipulação do passado para finalidades político-identitárias pode tomar duas formas básicas: podem se apresentar ou como distorções conscientes da realidade ou, mais comumente, podem estar apoiadas em anacronismos. É neste sentido que os usos da História são bastante sutis, à medida que poucas vezes suas informações podem ser simplesmente descartadas. Mais comumente, as distorções se apresentam de modo mais camuflado e inseridas dentro de um quadro geral de afirmações tidas como válidas - o que complica o trabalho de desmascaramento dessas dimensões mitificadoras. E é por isso que "História fabricada é bastante comum, ainda que devamos distinguir entre suas utilizações meramente retóricas e as que implicam uma genuína restauração concreta" (HOBSBAWM, 2005: 28).

No caso da construção da matéria da revista The Economist republicada em Carta Capital é bastante patente este mecanismo de uma glorificação de um passado nacional que ganha tonalidades míticas e serve como justificador para características do tempo presente. O curioso é que também nas revistas brasileiras há a evocação das origens da nação norte americana para a demarcação de determinadas características essencialistas, como é o caso das matérias apresentadas. É o passado do outro que é posto em questão nestas construções. Neste caso, é necessário ir além da mera constatação de que o passado é um poderoso recurso na legitimação de uma nacionalidade e investigar qual é o papel argumentativo que a evocação destas origens mitificadoras assume nos textos em questão.

Essa conotação essencialista destinada a alguns grupos possui algumas características argumentativas próprias e diz respeito à forma como um grupo é retratado. Como colocam Perelman e Olbrechts-Tyteca (1996: 367), “a argumentação concernente ao grupo e aos seus membros é muito mais complexa do que a concernente à pessoa e aos seus atos, principalmente porque uma mesma pessoa sempre pertence a grupos múltiplos, mas, sobretudo, porque a noção de grupo é mais indeterminada que a de pessoa".

Embora seja uma noção complicada, as argumentações estruturadas em torno dos grupos costumam contribuir para a construção de uma estratégia particular que diz respeito ao fato de que a interação entre o indivíduo e o grupo é um mecanismo poderoso que pode ser utilizado para valorizar ou para desmerecer um dos elementos desta equação ${ }^{63}$. Em outras palavras, se o grupo é dotado de determinadas características

\footnotetext{
${ }^{63}$ Os exemplos dados por Perelman e Olbrechts-Tyteca, (1996: 368) elucidam bem este mecanismo: "insistir-se-á nos erros de certos arqueólogos para desqualificar os especialistas nessa matéria. Inversamente, se não podemos fazer nosso elogio, podemos apresentar-nos como adeptos de tal política
} 
positiva ou negativamente marcadas (que podem ser apresentadas a partir de uma série de construções, inclusive através de comentários de cunho histórico), constrói-se o sentido de tal forma que todos os membros deste grupo passam a compartilhar desta mesma qualidade. $\mathrm{O}$ contrário também pode ser posto em cena na medida em que determinados membros de um grupo podem contribuir para a elevação ou desqualificação da coletividade a que faz parte.

Os exemplos citados acima parecem se enquadrar neste primeiro grupo, em que características marcadamente positivas de um grupo são aludidas como forma de construir um campo de exemplaridade em torno de suas ações. $\mathrm{O}$ recurso à história serve como forma de explicitar esse conteúdo marcadamente positivo e engendram uma característica que deve ser tomada como essencialista: uma vez que ela é posta como presente na origem constitutiva desta nação, essa marca se torna perene, inviolável, refratária às contingências temporais. Desta forma, o apelo às origens, além de delinear uma plataforma explicativa para os fenômenos que estão sendo explicitados, também marcam este campo de exemplaridade (no caso de características marcadamente positivas) ou de demérito (no caso de características negativas), assumindo características notadamente essencialistas que contribuem para a demarcação deste efeito de sentido.

Esses exemplos podem ser multiplicados uma vez que não só o imaginário sobre o que significam os EUA e a sua origem é sustentado por este tipo de narrativa. Algumas reportagens, por exemplo, também procuram nos primórdios da história nacional a explicação para alguns comportamentos pouco éticos dos políticos brasileiros. Em "Hora de fazer a faxina", Veja tenta investigar, "munidos apenas dos mecanismos da psicologia mais comezinha e da história, o que leva um político a esta situação". Segundo ela:

A resposta mais lógica, amparada na história, é a fronteira indefinida entre o público
e o privado na vida nacional. Quando o d. João VI se mudou com a corte de Lisboa
para o Rio de Janeiro, em 1808 , os nobres foram alojados nas melhores casas da
cidade, das quais os donos foram sumariamente expulsos. Mas não eram eles os
proprietários? Eram. Até que uma necessidade específica do estado os privou do
que parecia um direito adquirido. Na mão oposta, são incontáveis os casos de altos
funcionários do império e da república que se valeram de suas funções públicas
para satisfazer suas necessidades particulares. Sarney é um herdeiro dessa
mentalidade, com raríssimas exceções, prevalente no Brasil (CABRAL, 01/07/2009:
82).

ou como membros de tal Igreja, o que é suscetível de constituir uma vigorosa recomendação. Cumpre observar que esta é uma aplicação da técnica eficacíssima que consiste em introduzir juízos de apreciação não expressos sob a aparência de juízos de fato indiscutíveis. $O$ orador não insiste na valorização implícita, pelos ouvintes, de todos os que pertencem ao grupo em questão é na medida em que ela parece ser natural que atua melhor". 
Para Ruth de Aquino, em sua coluna na revista Época, a forma como as patroas tratam suas empregadas também é uma característica brasileira que pode ser explicada a partir de uma origem em um passado longínquo. Segundo ela, "essa mordomia no Brasil, com origens na tradição escravagista, é alimentada pela profunda disparidade de renda" (AQUINO, 12/10/2009: 138).

O esquema argumentativo presente nessas matérias não é essencialmente diferente do exposto nas anteriores. Ele também alude a uma origem que, ao carregar marcas essencialistas, constrói, a partir do passado, uma estrutura de julgamento de valor em relação a esta marca e que adquire contornos explicativos em torno de um comportamento.

Este mesmo mecanismo essencialista também pode ser posto em relação a grupos bem menores. Em uma reportagem sobre o Democratas, IstoÉ resgata a origem do partido como uma arma acusatória, afirmando que em 2006 havia ocorrido a mudança do nome e que, com isso, ele "pretendia se livrar do estigma de herdeiro da Arena, do PDS, da ditadura militar e do carimbo de fisiológico e incapaz de sobreviver longe das benesses do poder (PARDELLAS, 18/02/2009: 50-51). Isso é reforçado em outros textos da mesma revista. Em outra ocasião IstoÉ coloca que "o DEM, partido com raízes na Arena e que apoiou a eleição de Sarney à presidência do Senado, viroulhe as costas" (COSTA, PEDROSA e PARDELLAS, 08/07/2009: 37). A mesma coisa é dita em outros termos no final do ano: "herdeira da Arena e do PDS, partidos fortes do regime de exceção, o PFL trocou o nome para DEM, na tentativa de sobreviver" (COSTA, 04/11/2009: 54-55) ${ }^{64}$.

O mecanismo envolvido aqui é bastante claro: a evocação à origem do grupo serve como forma de dotá-lo de determinadas características essencialistas e desautorizar as manobras que objetivem mudar esta imagem, ao colocá-los como falsos ou pouco confiáveis. Isso pode ser notado claramente no nível dos pressupostos (com os marcadores de pressuposição como "pretendia se livrar", que indica um campo teleológico, ou "estigma", que remete às marcas primeiras e indeléveis do grupo) e dos subentendidos (que articula este campo de pouca confiança nos esforços empreendidos pelo partido com a mudança do nome).

\footnotetext{
${ }^{64}$ Este recurso também é utilizado por Carta Capital. Em todas as reportagens a respeito do escândalo de corrupção do governo Arruda, ela utilizou termos como "Arruda era a grande aposta política do ex-PFL" (FORTES, 09/12/2009: 24) ou "talvez seja esta, no momento, a melhor notícia para os ex-pefelistas" (FORTES, 16/12/2009: 28) para se referir ao DEM.
} 
Podemos pensar neste tipo de uso da história de maneira similar ao que vínhamos tratando até então. A noção de "características essenciais de um grupo" - que diz respeito a marcas que, colocadas logo na origem de um grupo, ganham um contorno perene e servem, por isso, para demarcar um modo de agir específico - está estruturada em torno das expectativas sociais que se tem em relação a esta coletividade. Assim, "essas construções intelectuais se empenham em associar e em explicar fenômenos particulares, concretos, individuais, tratando-os como manifestações de uma essência que se expressa igualmente em outros acontecimentos, objetos, seres ou instituições" (PERELMAN e OLBRECHTS-TYTECA, 1996: 372). Este mecanismo pode ser posto em ação a partir de uma série de estratégias - que não precisam estar relacionadas necessariamente ao uso do passado - muito embora a evocação histórica seja um mecanismo comum neste tipo de construção de sentido.

Ele diz respeito ao fato de que determinados comportamentos dos indivíduos podem ser explicados "não só pelo fato de pertencerem a um grupo, mas também pela época ou pelo regime com que se relacionam". Assim, "falar do homem de Idade Média ou de um comportamento capitalista é tentar mostrar como esse homem e esse comportamento participam de uma essência e a expressam, e como, por seu turno, permitem caracterizá-la” (PERELMAN e OLBRECHTS-TYTECA, 1996: 372).

Conforme colocamos, a alusão às origens contribui para reforçar este caráter essencialista e funciona como um poderoso direcionador de sentidos e explicações.

Dentro deste mecanismo, tudo o que se afastar desta essência é tomado como errado ou como desvio, uma vez que o comportamento "normal" está sempre relacionado a esta essência. "O recurso à noção de essência permitirá reportar acontecimentos variáveis a uma estrutura estável, que seria a única a ter importância" (PERELMAN e OLBRECHTS-TYTECA, 1996: 373). Como a única a ter crédito, a essência é posta como o contrário do desvio, digno de desconfiança.

É por este mecanismo, chamado por Perelman e Olbrechts-Tyteca de desvinculação entre o ato e a essência, que IstoÉ constrói um campo de entendimento e um efeito de sentido relacionado ao descrédito da mudança de nome do Democratas. A sua essência já havia sido demarcada pela revista através do recurso à origem ("herdeiro da Arena, do PDS, da ditadura militar e do carimbo de fisiológico") e as mudanças, dentro deste escopo, são invalidadas a partir da alusão a esta mesma essência.

Este não é, contudo, o único efeito de sentido que pode ser construído. Se em algumas reportagens é reforçada a marca indelével desta origem no presente, em outras, no entanto, este início é aludido como forma de quebrar as expectativas em torno de 
uma essência pretensamente esperada. Aqui, uma origem nobre é aludida como forma de enfatizar a ruptura ou o desvio de um determinado movimento em relação aos seus objetivos iniciais. A demarcação de um início, nestes casos, ainda continua a representar pontos fortes da narrativa, nos termos que tratamos anteriormente. Não obstante isso, o efeito de sentido que elas engendram são um pouco diferentes.

Em reportagens como estas, a evocação das origens não raro ganha contornos acusatórios. É o que acontece, por exemplo, no texto da IstoÉ sobre o apoio que Orestes Quércia (do PMDB) estaria articulando nas bases de seu partido para os candidatos tucanos e relembra: "por ironia, o PSDB, que hoje Quércia ajuda, nasceu de uma dissidência do PMDB" (PARDELLAS, 27/05/2009: 46). Ou, ainda, na mesma publicação, o comentário em torno do PT de que "o partido que nasceu em 1980 empunhando a bandeira da ética, mais uma vez se apequenou" (COSTA e NICACIO, 26/08/2009: 36).

Não são termos muito diferentes do que é colocado pela revista Veja quando ela afirma que "fundado em 1965, o Movimento Democrático Brasileiro, o então MDB, sobreviveu como alternativa institucional de oposição ao regime militar por vinte anos. A partir da chegada de José Sarney à Presidência, em 1985, o partido perpetuou-se no poder, usando a máquina pública como principal financiador de seu projeto" (CABRAL e ESCOSTEGUY, 25/02/2009: 47).

Em construções como estas, o que está em jogo não é uma essência que se renova ou que encontra solidariedade no presente (como em exemplos anteriores), mas sim, uma essência que foi esticada até o seu ponto de ruptura e, como tal, descaracterizou-se e afastou-se de suas marcas iniciais.

Nestas reportagens, a ênfase na ideia de desmerecimento ou da incoerência de um partido é posta a partir da ruptura com seus objetivos iniciais ou do afastamento de uma simbologia que, em um momento fundador, ele estaria supostamente envolto.

Ligados a uma ideia de orientação nos discursos, os pressupostos mobilizados aqui estão relacionados a uma ideia de ruptura entre o passado e o presente, de forma que os marcadores de pressuposição - tais como "por ironia" ou "a partir" (de então) confirmam esta ideia de uma origem que só é mostrada para que a imagem do corte entre o atual e o decorrido se torne mais marcante. Neste caso, os componentes retóricos dos enunciados também estão relacionados a uma desvinculação entre o ato e a essência, mas, diferentemente de exemplos anteriores, ele está calcado em um rompimento da vinculação de coexistência simbólica. Os subentendidos mobilizados, 
neste contexto, dizem respeito não mais à transferência dos valores ligados a esta origem, mas sim, ao transporte dos valores relacionados à apreciação desta ruptura.

Dentro do modelo proposto por Ducrot, teríamos o seguinte mecanismo:

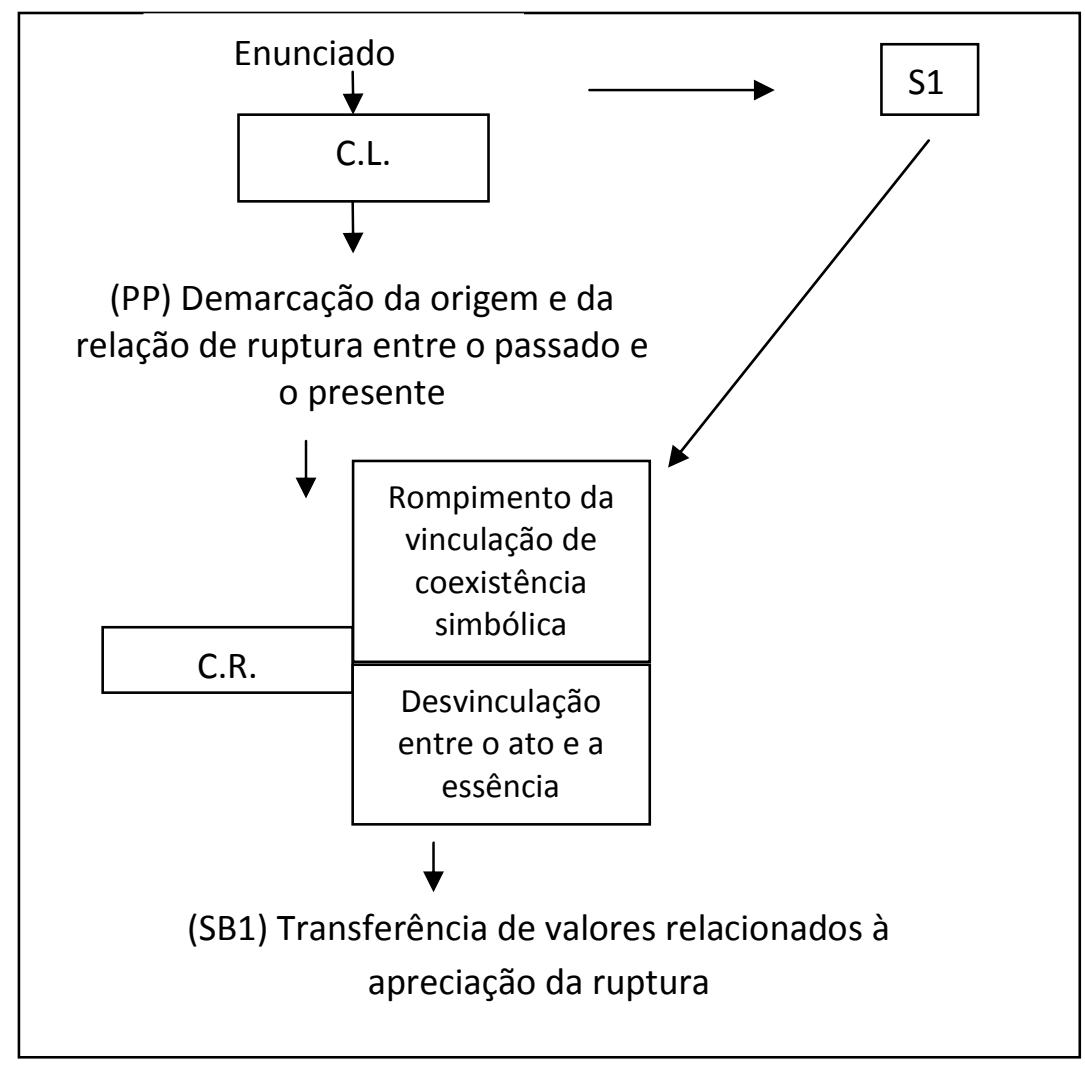

O tom acusatório de reportagens como estas pode estar engendrado também em outros lugares para além de uma denúncia de falta de coerência. Ele pode estar posto, igualmente, na evocação de uma inadequação destas reminiscências do passado no presente. Assim, algumas evocações de origem contribuem para mostrar a antiguidade de determinada temática para, em seguida, construí-la em termos de um estranhamento em relação aos tempos atuais.

Isso é bastante patente, por exemplo, na coluna de Thomaz Wood Júnior publicada na Carta Capital de 28 de Janeiro de 2009, quando este comentava sobre a questão dos empregos vitalícios como o de alguns professores em universidades de administração londrinas. O colunista assumia uma posição de crítica em relação a isso e afirmava que "em meio a um mar de empregos precários e incertezas, ainda existem ilhas de estabilidade. Perguntar ofende: deveriam existir?" (WOOD JR., 28/01/2009: 25). Em meio a sua argumentação, o colunista coloca que "o conceito de ternure (na prática, uma garantia de emprego vitalício) tem origens na Idade Média, quando os 
professores necessitavam de proteção contra políticos, de forma a garantir liberdade de trabalho e de expressão" (WOOD JR., 28/01/2009: 25).

A demarcação da origem parece ter aqui um papel bastante específico: ao apresentar as condições a partir das quais o emprego vitalício em universidades teria surgido, enfatiza-se a ausência ou a falta de existência destas condições no presente, o que acaba por engendrar subentendidos relacionados ao questionamento da manutenção desta prática no futuro. A última frase do texto de Wood Jr. confirma o seu posicionamento quando coloca que "no entanto, a história insinua que anacronismos podem persistir por algum tempo, porém terminam soterrados" (WOOD JR., 28/01/2009: 25).

Aqui também estamos diante de um componente retórico estruturado a partir da desvinculação entre o ato e a essência que, neste caso, é posto através de uma falta. É justamente a ausência no presente das condições postas na origem que organiza a argumentação e que mostra a prática como anacrônica.

Um outro exemplo a este respeito está em uma reportagem sobre a Academia Paulista de Letras. Segundo a revista Época, ela, “assim como a brasileira, é uma cópia tupiniquim da Academia Francesa de Letras, fundada em 1635”. A inadequação aos tempos atuais é descrita da seguinte forma: "a estrutura de uma academia de letras era compatível com a sociedade aristocrática que a engendrou, mais de 150 anos antes de a Revolução Francesa inaugurar a era da modernidade. A entidade era uma das mais importantes referências culturais, uma guardiã da literatura e da norma gramatical culta e um círculo restrito, de altíssimo nível e dificílimo acesso". O problema, segundo a revista, é que "hoje as academias tentam manter a mesma ordem e pompa. Fatalmente, soam anacrônicas em tempos de internet" (SANCHES, 10/08/2009: 63).

A desvinculação entre o ato e a essência pela ausência pode ser explicado nos termos de que "a falta só pode ser invocada quando se tem uma noção, vaga ou precisa, da essência em relação à qual ela se determina. O critério que permite provocar essa falta é inteiramente subordinado à concepção que se tem da forma da essência" (PERELMAN e OLBRECHTS-TYTECA, 1996: 375). Em outras palavras, a falta só é percebida quando posta em relação a algo que a determina: no caso da crítica ao emprego vitalício ou da ABL, as condições de seu surgimento determinam a essência do elemento que justificaria sua existência. É pela ausência deste elemento essencial que a crítica se processa.

É por isso que "a falta, mais do que a negação da qual ela pode ser aproximada, é característica da argumentação sobre os valores, sobre o que deve ser feito" 
(PERELMAN e OLBRECHTS-TYTECA, 1996: 375). Uma vez que a essência não encontra espaço para remanejamentos sem a pena de uma descaracterização total, o espaço deixado pela falta deve ser preenchido por outra prática, o que justifica este relance para o futuro.

É necessário ficar atento, contudo, ao fato de que, em algumas ocasiões o efeito pretendido pode ser inverso: mostrar a antiguidade de determinada prática pode ser também um modo de lhe conferir prestígio e uma aura de tradição. É o caso da reportagem da Carta Capital que, ao fazer o perfil de um tradicional restaurante do sul da França diz "o Oustau de Baumanière foi fundado há 64 anos em uma quinta construída em 1634, no vilarejo de Les Baux-de-Provence" (ATHAYDE, 17/06/2009: 10). Ou, então, em uma reportagem da IstoÉ sobre o foie gras que afirma que "a técnica [de preparo] existe desde o antigo Egito" (JORDÃO, 23/09/2009: 74). Ou, ainda, em Veja, ao tratar sobre o curso de direito, confirma sua tradição dizendo que "as origens dessa deferência remontam ao período colonial, quando os ricos enviavam seus filhos para estudar direito na Universidade de Coimbra, em Portugal. Entre outras facilidades, o diploma lhes franqueava acesso aos cargos mais altos da administração pública" (VEJA, 11/11/2009: 180).

É um tipo de recurso muito parecido com o da revista Época que, ao criticar a taxação da caderneta de poupança pelo governo, conclui sua reportagem afirmando que “criada no Brasil há 148 anos por Dom Pedro II, a poupança sobreviveu até mesmo a planos econômicos desastrosos. Sua simplicidade e segurança são seus trunfos. Lula sabe disso. Mal desembarcou no Brasil e pediu cautela no assunto" (RAMOS, 23/03/2009: 50).

A origem remota da caderneta de poupança, mais do que uma mera informação, funciona, na narrativa desta reportagem, como um argumento a favor de sua manutenção. A aura de prestígio que essa origem confere ao mecanismo funciona como uma espécie de atestado de seu bom funcionamento, de forma que o posicionamento contrário (a taxação) é desacreditado a partir da informação histórica acrescentada.

Nestes exemplos, portanto, é justamente a antiguidade da prática que lhe confere legitimidade e que defende, de certa forma, a sua invariabilidade para o futuro.

Como parece ter ficado patente a partir dos exemplos destacados, o uso do passado com finalidades essencialistas é bastante comum nas sequências e funções narrativas de origem. No corpus consultado, de Janeiro a Dezembro, elas correspondem a aproximadamente $43 \%$ de todas as funções e sequências narrativas deste tipo. Dividindo essa porcentagem nos quatro veículos estudados, temos a seguinte tabela: 


\begin{tabular}{ccc} 
& $\begin{array}{c}\text { Total } \\
\text { (narrativas de origem) }\end{array}$ & $\begin{array}{c}\text { Narrativas que usam } \\
\text { argumentações de caráter } \\
\text { essencialistas }\end{array}$ \\
\hline Veja & 423 & $177(41,84 \%)$ \\
Época & 409 & $163(39,85 \%)$ \\
Istó́ & 362 & $153(42,26 \%)$ \\
Carta Capital & 447 & $214(47,87 \%)$ \\
\hline
\end{tabular}

Pela tabela, podemos perceber que é a revista Carta Capital que faz o uso mais frequente deste expediente, seguida por Veja, IstoÉ e Época, respectivamente.

Por fim, há, ainda, um outro tipo de uso do passado que remete a uma origem que é bastante usado no jornalismo e é também um tanto particular, no sentido em que se estrutura de uma forma diversa das evocações que vínhamos tratando até o momento. Ele diz respeito à evocação dos ancestrais - mais especificamente dos homens das cavernas - como uma forma de engendrar uma explicação genética dos fenômenos sociais.

Existe mesmo uma quantidade bastante significativa de matérias que recorrem a este tipo de recurso. A origem do beijo, por exemplo, é explicada por IstoÉ, nos seguintes termos: "na teoria da evolução das espécies, o cientista Charles Darwin afirmava que a origem dessa carícia é antiga. Seria a sofisticação das mordidas que os macacos trocavam nos rituais pré-sexuais" (FRUTUOSO e MAMBRINI, 25/02/2009: 62). A gentileza, por sua vez, também "é estratégia evolutiva. A teoria da 'sobrevivência do mais gentil' (...) verificou que a gentileza era componente fundamental da sobrevivência de comunidades antigas, porque a cooperação melhorava as condições do grupo" (MAMBRINI, 07/10/2009: 67).

Também Época faz remissão a explicações deste tipo em um grande número de reportagens como quando, por exemplo, ela explica que a queda da bolsa e a depressão econômica podem estar diminuindo a libido masculina com base nos argumentos de "alguns cientistas que acreditam que essa queda do interesse sexual seja parte de um mecanismo evolutivo perverso - a boa e velha seleção natural agiria para evitar que homens incapazes de sustentar seus descendentes sob pressão se reproduzam" (COLAVITTI, 23/02/2009: 82). Ou, ainda, quando coloca que a "vaidade é diferente para cada um dos sexos". E isso "por motivos que a biologia evolutiva já explicou à exaustão, desde o tempo das cavernas a mulher tem sido selecionada para a beleza (que está ligada à juventude, que, por sua vez, está relacionada a maior sucesso reprodutivo". 
Os homens, por sua vez, "sempre foram selecionados pelo poder e pela força (o macho provedor, capaz de sustentar os descendentes e garantir que os seus genes sobrevivam)" (COLAVITTI e MENDONÇA, 16/11/2009: 121).

A evolução se torna explicação até para os esportes. Para Veja, o desempenho impressionante de Usain Bolt em relação aos seus adversários "se deve às origens étnicas". Isso porque "no passado, populações isoladas desenvolveram capacidades físicas específicas que ficaram impressas nos genes. Corredores com herança genética da África Oriental, como os etíopes e os quenianos, têm nos músculos grande quantidade de fibras de contração lenta, o que os torna vencedores naturais de maratonas" (TEIXEIRA, 26/08/2009: 99). O fato de as mulheres pintarem o cabelo também é olhado sob esta ótica: “a explicação evolutiva, que virou o manual universal de respostas fáceis para questões complexas, estabelece que as mulheres grisalhas evidenciam a perda de atributos reprodutivos, enquanto os homens nas mesmas condições emanam poder e distinção" (MOHERDAUI, 14/10/2009: 129).

Em um trabalho sobre o tema, Tognolli (2003: 18) trata o biologismo genético como uma espécie de zeitgeist, um espírito da época na ciência, uma vez que "num mundo que cada vez mais necessita de um culpado, achamos um, com o estatuto da ciência chancelando tudo: o problema e a resposta estão em cada indivíduo, na sua carga genética". Neste contexto, condições sociais, psicanalíticas ou ambientais adquirem um estatuto secundário em relação aos problemas biológicos que acompanham cada indivíduo e que lhes foram legados ao longo da evolução da espécie.

Trata-se de um discurso que não foi criado pela mídia, mas que, não obstante, encontraria nela um grande meio de ressonância e divulgação. Para Tognolli (2003:19), “a máquina desempenhou no início do século XX o mesmo papel que a natureza no século XVIII ou o gênio no período romântico: era o verdadeiro sujeito da história. Hoje, o gene é o sujeito da história. A imprensa coloca a resposta final dos geneticistas".

A exposição das ideias darwinistas encontra um espaço receptivo na mídia desde muito tempo. Só para se ter uma ideia, a repercussão das Conferências Populares da Glória, no Rio de Janeiro, realizadas entre 1875 e 1880, cujo tema eram as ideias do biólogo britânico, foram recebidas pela imprensa em termos bastante elogiosos ${ }^{65}$.

\footnotetext{
${ }^{65}$ As Conferências Populares da Glória eram "preleções públicas realizadas inicialmente na escola da Freguesia da Glória. Em 1873, o conselheiro Manoel Francisco Corrêa criou as Conferências a fim de estabelecer um novo espaço para a divulgação da ciência, das artes e da literatura na Corte. Os oradores que se apresentavam, em sua maioria médicos e bacharéis, já eram reconhecidos em outros círculos letrados e institucionais. O público frequentador desse local, composto pela elite letrada carioca, recebeu de forma positiva o evento, transformando-o em mais um espaço de sociabilidade. As Conferências
} 
Segundo Carula (2008), o jornal $O$ Globo anunciou as conferências destacando que essas teorias já estariam difundidas nos "países mais adiantados" e isso poderia ajudar a civilizar o Brasil. O Jornal do Commercio enfatizou que se tratava de uma "teoria moderna de história natural, que atualmente preocupa a atenção dos mais eminentes naturalistas e sábios da Europa e dos Estados Unidos". Em outra reportagem destacava o "serviço à pátria e ao povo" que seus realizadores estariam promovendo. Mesmo permeada por algumas polêmicas, desde essa época a grande imprensa se referia as teorias darwinistas de uma forma bastante positiva.

Também o periódico $O$ Vulgarizador publicou uma série, entre 1877 e 1878, assinada por João Zeferino Rangel de S. Paio, intitulada "O darwinismo: cartas a uma senhora" em que ele divulgava alguns dos pontos do darwinismo que foram mais aceitos em terras brasileiras, "como a 'luta pela vida', a 'seleção natural' e a 'sobrevivência dos mais aptos"” (VERGARA, 2007).

Populares desde o século XIX no Brasil, as ideias evolucionistas de Darwin ganharam ainda mais publicidade com os sucessos editoriais de autores como Richard Dawkins ou Jared Diamond. Esse tipo de relacionamento biológico com o passado, pautado pelo evolucionismo e pela possibilidade de entendimentos dos comportamentos humanos (como o ato do beijo ou a falta de desejo sexual durante períodos de penúria econômica) através da evolução encontra grande ressonância nas revistas.

Este tipo de apelo às origens - que toma a evolução como motor da história - está presente em 5,5\% das reportagens de nosso corpus (referente às narrativas de origem), no período de Janeiro a Dezembro, com um total de 90 textos. A divisão em cada uma das revistas analisadas segue a seguinte tabela:

\begin{tabular}{ccc} 
& $\begin{array}{c}\text { Total } \\
\text { (narrativas de origem) }\end{array}$ & $\begin{array}{c}\text { Narrativas de origem que citam } \\
\text { a teoria da evolução }\end{array}$ \\
\cline { 2 - 3 } Veja & 423 & $42(9,92 \%)$ \\
Época & 409 & $28(6,84 \%)$ \\
Istó́ & 362 & $12(3,31 \%)$ \\
Carta Capital & 447 & $8(1,78 \%)$ \\
\hline
\end{tabular}

obtiveram força política, constituindo-se como um espaço público privilegiado para a formação de opinião pública. Elas eram anunciadas e comentadas nos grandes jornais, que traziam artigos debatendo as preleções e as ideias ali expostas. A repercussão na imprensa foi importante tanto por dar legitimidade ao espaço das Conferências, quanto por reverberar discussões sucedidas, colaborando assim na disseminação e cristalização das ideias apresentadas" (CARULA, 2008). 
Como o quadro mostra, a revista que mais utiliza narrativas de origem que citam a teoria da evolução é a revista Veja - com um total de 9,92\% em relação ao total das funções e sequências narrativas de origem. Ela é seguida por Época, IstoÉ e Carta Capital. A baixa porcentagem nesta última tem relação com a quantidade bastante baixa de matérias de comportamento que esta revista costuma publicar.

\section{As funções e sequências narrativas de origem na construção das reportagens:}

José Ferrarer Mora chama a atenção para o fato de que recorrer às condições ou às circunstâncias que contribuíram para a formação de um determinado tema não é uma condição suficiente para que possamos inferir disso um significado ou um alcance explicativo acerca deste assunto. Assim, “embora uma descrição da formação do sistema solar possa não ser irrelevante para entender a estrutura deste sistema, supõe-se que uma compreensão adequada de tal estrutura implica a referência a leis físicas". Do mesmo modo, "ainda que uma descrição da história das relações humanas de parentesco possa não ser irrelevante para uma compreensão dessas relações, supõe-se que um entendimento adequado destas últimas pressupõe a referência a leis antropológicas (e, possivelmente, biológicas) (MORA apud TOGNOLLI, 2003: 13-14).

Não obstante isso, podemos encontrar no jornalismo uma série de situações em que o ponto inicial de uma questão serve como um guia explicativo que engendra significações em torno dela. No presente capítulo buscamos delinear a forma como a escolha de uma origem para determinado problema ou questão do presente, dentro do jornalismo, pode ser um recurso bastante útil, na medida em que ela pode demarcar um dos pontos fortes da narrativa, contribuindo para alinhavar uma determinada significação que se quer confirmada. Uma vez que o texto é caracterizado justamente por uma série de ambiguidades, desvios e mal-entendidos, a delimitação de um início contribui para costurar um dos nós de sentido do texto e serve mesmo como uma ferramenta de desambiguação.

Levando-se em consideração o fato de que demarcar um início ou uma origem pode ser um procedimento arbitrário (uma vez que poderíamos demarcar um grande número de inícios possíveis para uma mesma estória, dependendo da forma como conduziremos nosso enredo) isso pode ser feito de diferentes maneiras.

Delimitar certos eventos históricos como origens de um problema, pode ter um efeito de sentido bastante específico quando estes inícios adquirem um caráter de "símbolo". Desta forma, eventos como a ditadura militar (símbolo do autoritarismo e de um tipo de política com fortes conotações negativas) podem contribuir para a formação 
de julgamentos depreciativos acerca das questões retratadas. Isso é possível, no nível dos subentendidos, através das vinculações de coexistência simbólica, quando há uma transferência entre o símbolo e o simbolizado.

Outra forma de construir sentidos a partir da origem é apelar para características essencialistas dos problemas retratados. O mecanismo de coexistência simbólica continua a funcionar, neste caso, porém, os atributos que servem de parâmetro para o julgamento passam a estar relacionados a subentendidos que este início demarcado carrega. Ao aludir a marcas essencialistas, as origens podem contribuir para demarcar determinadas características como fixas e refratárias às contingências históricas. Assim, a origem constrói, a partir do passado, um direcionamento para determinados julgamentos de valor em relação a esta marca - que, por fim, passa a apresentar alguns contornos explicativos em torno de um tema.

Este mecanismo também pode ser usado de forma inversa e explorar a ruptura entre o ato e a essência, promovendo uma mudança no estatuto da vinculação de coexistência simbólica. Quando a origem não mais representa o presente, os subentendidos mobilizados passam a estar relacionados ao transporte dos valores relacionados à apreciação desta quebra.

Diferentes entre si, estas formas de utilização da história para a demarcação de um início apontam para a noção de que a mudança do nó narrativo relativo à origem pode contribuir bastante para a modificação da significação de um evento do tempo presente.

E é por isso que, ao evocar a história, as matérias citadas invocam uma origem que descreve uma atualidade. 


\section{CONSIDERAÇÕES FINAIS}

\section{EVOCAR A HISTÓRIA PARA INVOCAR LUGARES DE SENTIDO AS NARRATIVAS JORNALÍSTICAS E A REMISSÃO AO DECORRIDO}

Muitas metáforas já foram utilizadas para caracterizar o esquecimento. Quando a memória é descrita tal como uma paisagem, o esquecimento sempre ocupa "os locais ermos, os terrenos arenosos, nos quais é desmanchado pelo vento aquilo que deve ser esquecido" (WEINRICH, 2001: 21). Ele pode também ser representado como "a funda cova do eu (Hegel), ou como o poço do passado (T. Mann), ou abismo das olvidas eras (Tomás Ribeiro)", como "esquecimento trevoso (Schiller) ou, esquecimento sombrio (Victor Hugo)" (WEINRICH, 2001: 21-22).

É um engano, no entanto, pensar que somente as metáforas negativas podem caracterizá-lo. O não esquecimento já foi igualmente comparado com a insônia "adormecer significa esquecer" (VALERY apud WEINRICH, 2001: 22) - e o próprio esquecimento já foi metaforizado como as águas do rio Lete que fazem as almas dos mortos se esquecerem de suas vidas pregressas para ficarem livres para um novo corpo. Já foi caracterizado, ainda, como uma arte, de forma que, tal como a ars memoriae, pudesse existir uma ars oblivionalis ${ }^{66}$.

No campo do jornalismo, no entanto, o esquecimento parece não gozar de boa reputação e, embora ele seja condição necessária de toda a produção textual, é muito comum encontrarmos a palavra "esquecer" combinada com a sua negativa nas páginas da imprensa. É quase prosaico quando nos depararmos com expressões como "a inflação alta, convém não esquecer, foi sempre o instrumento mais perverso" (VEJA, 27/09/1995: 31) ou "convém não esquecer que há bicheiros na cadeia" (VEJA, 26/10/1994: 29) ou, ainda, "não se deve esquecer que, nesse período, houve renúncia fiscal estimada em R\$ 6,5 bilhões” (FSP, 20/04/2009).

O tom desta "conveniência da lembrança" é não raramente acusatório e implica a imputação de responsabilidades para outros setores da sociedade civil, como no editorial da Folha de São Paulo de 02/08/2009, que afirmava que "se o poder Judiciário

\footnotetext{
${ }^{66}$ Neste sentido, Weinrich conta a anedota de Cícero no qual Simônides teria convidado Temístocles para fazer aulas sobre a arte da memória, para que este pudesse se recordar de tudo o que quisesse. "Temístocles teria respondido que não precisava de uma arte da memória. Antes de recordar tudo o que fosse possível, preferia aprender dele a esquecer aquilo que quisesse esquecer (...). Segundo outra versão da mesma anedota, Temístocles teria respondido de maneira categórica que não estava interessado em uma arte da memória (ars memoriae), mas, em vez disso, em uma arte do esquecimento (ars oblivionis)" (WEINRICH, 2001: 32).
} 
tem o dever de punir com severidade aqueles que delinquiram, não pode esquecer a contrapartida que dele se espera".

O esquecimento só é bem quisto no jornalismo quando combinado com outro pilar da prática - a novidade. Assim, a revista Veja pode afirmar em um editorial que "depois de vasculhar arquivos e bibliotecas, Sá Corrêa dedicou-se a esquecer o que havia lido sobre Niemeyer e, durante mais de um mês, falou quase todos os dias com o arquiteto, buscando descobrir novidades" (VEJA, 12/07/1995: 29). Mas mesmo aqui a palavra "esquecimento" não é usada em seu sentido habitual, como "deixar sair da memória" ou "perder a lembrança" (FERREIRA, 1993), no sentido que indicaria um lapso ou uma lacuna na informação. Ela remete, ao contrário, a um sentido de acréscimo de ainda mais informações; de um reforço da memória, afinal, o repórter não se confinaria ao que já havia sido escrito, buscando acrescentar novos dados e contribuindo, com isso, para que o que estava escondido, esquecido, pudesse vir á tona.

Desta forma, podemos encontrar no jornalismo uma atividade social obcecada pelo dever de lembrança. Trata-se mesmo de uma ideia fixa, na medida em que o papel de watchdog da profissão, como aquele que deve lembrar aos outros de uma verdade que foi escondida ou esquecida, faz parte da metanarrativa que sustenta a prática.

Mais do que isso, o esquecimento parece estar relacionado mesmo, como coloca Huyssen (2005: 22), com certa "inabilidade para comunicar" e não é por acaso que "falamos com facilidade de uma ética do trabalho da memória, mas provavelmente negamos que poderia existir uma ética, muito mais do que simplesmente uma patologia do esquecimento. A memória, de qualquer forma, perece requerer esforço e trabalho; o esquecimento, ao contrário, simplesmente acontece".

É a partir dessa apropriação que os veículos midiáticos fazem da história que alguns autores, como Virilio (2006: 93), por exemplo, falam sobre uma memória que está sempre no gerúndio, ou seja, sempre "em acontecendo". Ao tomar a noção de memória como uma espécie de presença, esta deixa de ter um lugar real que não seja a própria atualidade, de forma que "seu lugar é o live".

Os fatos do passado (ou os lugares de memória) ganham um estatuto "presentificado", na medida em que se tornam contemporâneos de quem os observa. Como coloca Eugênio Bucci (2002: 156-157), esta apropriação do passado pelos veículos midiáticos se destacam pelo fato de que eles "não contam o que havia no passado", e sim, "mostram o passado outra vez, tornando-o presente". E isso se tornaria tanto mais evidente quanto o passado se tornasse espetáculo: ao incorporar as diversas temporalidades em apenas um grande gerúndio, elas podem "transformar o que é 
passado em presente - e um herói de 30 anos atrás em um ícone pop a quem os passantes pedem autógrafo".

Ao longo deste trabalho, procuramos explorar algumas questões que dizem respeito a essa obsessão jornalística com a memória, a essa remissão constante a dados do passado nas reportagens mesmo que se trate, paradoxalmente, de uma atividade cujos pontos norteadores sejam, justamente, as questões do tempo presente. Mesmo que isso possa nos causar um espanto inicial, procuramos estudar como essa visada em direção ao passado se constitui como uma característica narrativa da imprensa informativa e interpretativa semanal, dizendo respeito mesmo a um modo de semantização do fato jornalístico.

Essa questão abarca diversos vieses relacionados tanto ao reforço de determinadas características da imprensa interpretativa semanal quanto às maneiras a partir das quais o jornalismo dota o mundo de sentido, de forma que os fatos do passado funcionam mesmo como um modo de circunscrever o novo dentro de um quadro de significados já estabelecidos.

Ao se configurar como uma prática que se estrutura a partir de um claro desejo de memória, a atividade jornalística encontra na história uma aliada poderosa na semantização dos eventos que relata, de forma que o passado fornece determinados símbolos poderosos que dão a ver determinadas formatações para a atualidade. Não é surpreendente, sob este ponto de vista, o fato de que tantas matérias publicadas nas revistas informativas semanais façam remissões a eventos do passado. E assim, "a interpretação de temas ressignificados mostra que o discurso, a história e a memória constroem movimentos de sentidos" (GREGOLIN, 1997: 56) que argumentam a favor de determinado entendimento em torno do tempo presente.

Dentro desse contexto, uma das questões que procuramos explorar diz respeito ao fato de que embora muitos produtos midiáticos façam remissões à história, as narrativas jornalísticas parecem possuir algumas características específicas dentro desse quadro mais geral de produções que fazem apropriações do passado. Uma vez que o trabalho jornalístico se estrutura tanto em torno de um discurso referencial (na medida em que instiga o camuflamento de seu estatuto enquanto artefato verbal o tempo inteiro) e como um organizador coletivo de valores (a partir de uma construção imaginária de vínculos societários), procuramos estudar, nos capítulos I e II, a problemática de que, ao evocar a história, o jornalismo invocava a edificação de estratégias referenciais e também uma construção de um tempo e de um comum imaginários. 
Quanto à primeira questão - que diz respeito ao tipo de narrador presente nas narrativas jornalísticas e ao modo como os efeitos de verdade são articulados - podemos dizer que o uso dos dados históricos é uma das estratégias possíveis que engendram o apagamento do sujeito da fala dentro das narrativas jornalísticas. Isso acontece na medida em que é um terceiro ligado a uma posição de autoridade (a História) que discorre sobre o assunto, instaurando a dimensão de um não-eu, ao anular a existência da pessoa passional do jornalista (e, consequentemente, ao efetuar a sua substituição por uma entidade objetiva), colocando-o como um mero coletor de evidências vindas do passado. Ao ocupar o lugar de um discurso constituinte, é como se o Passado fundado pela História se posicionasse nas narrativas jornalísticas como uma testemunha insuspeita frente aos sentidos que podem ser articulados para o acontecimento do presente noticiado, de um lado, e o próprio jornalista, de outro, uma vez que este está inserido em um tipo de jornalismo explicitamente interpretativo.

Ao ser posto como um discurso constituinte, podemos dizer que a História também engendra um lugar de "lugares-comuns" de uma sociedade dentro das narrativas jornalísticas o que, desta maneira, contribui para a construção de espaços de sentido já pré-articulados - ou, em outras palavras, para a inscrição do fato jornalístico em um campo de discursos que são repetidamente postos como inéditos em uma rede de significações sociais, reintegrado-o em um conjunto de significados já estabelecidos. Este mecanismo tem também relação direta com uma construção imaginária do tempo, na medida em que os sentidos de um evento jornalísticos são estabelecidos a partir de seu posicionamento dentro de um conjunto de causas e conseqüências, ou em outros termos, de um passado e de um futuro construídos.

É necessário levar em consideração, contudo, que embora possamos dizer isso a respeito de todas as matérias analisadas, há diferentes efeitos de sentidos mobilizados a partir da inserção de um dado histórico em uma narrativa jornalística. Nos capítulos III, IV e V procuramos estudá-los, a partir das funções e sequências narrativas de "trajetórias pessoais", "comparação e disjunção" e "origem", respectivamente. Por um momento, gostaríamos de nos deter um pouco sobre estes resultados.

No que concerne às "funções e sequências narrativas de trajetórias pessoais" que fazem menção aos atos passados da vida de um personagem retratado -, podemos dizer que os efeitos de sentidos engendrados ali se estruturam a partir da vinculação de coexistência pessoa-ato. Uma vez que isso implica uma construção argumentativa a partir da qual algo que é próprio do indivíduo é correlacionado a algum tipo de ação transitória (ou, em outras palavras, onde há uma sobredeterminação complexa entre o 
valor que nós damos ao indivíduo e o valor que nós atribuímos ao ato), nestas reportagens, o passado é colocado como um parâmetro de avaliação para o reconhecimento moral daquele que fala ou daquele que age no presente.

Desta forma, estas informações do passado ajudam a preencher alguns buracos semânticos existentes em toda a construção narrativa de um personagem - na medida em que este aparece na reportagem como um morfema vazio que tem os seus sentidos definidos aos poucos, ao longo do texto e com a ajuda destas estórias de trajetórias de vida no passado - mesmo que se trate de personalidades que já são conhecidas do grande público.

Ligados ao preenchimento destes morfemas vazios, os dados históricos são importantes articuladores de efeitos de sentido e atuam na semantização do acontecimento jornalístico na medida em que um personagem não é definido em uma narrativa jornalística apenas pela posição que ele ocupa no momento em que se desenrola a estória que está sendo contada (momento da veiculação da matéria). A definição de sua participação será posta também a partir de determinados posicionamentos anteriores, ou, em outras palavras, a partir da relação estabelecida entre seu posicionamento presente e os seus atos do passado. Mais do que isso, a construção deste passado - ou desta trajetória de vida - irá depender sempre do discurso que se quer respaldar em torno do comprometimento moral daquele que age ou daquele que fala.

Além disso, também é importante considerar que este tipo de função ou sequência narrativa que faz uso da história também é importante porque fixa uma redundância no narrado. Mesmo que um personagem já tenha sido descrito como maucaráter (ou que seja publicamente conhecido como tal) pelos seus atos presentes (relacionados a atos socialmente reconhecidos como reprováveis, tal como escândalos de corrupção ou violência), os atos passados funcionam como uma espécie de ativo que, de uma determinada maneira, cristaliza e reforça esta imagem, a partir de vinculações metonímicas.

E assim, ao evocar a história, o jornalismo invoca uma posição ocupada para os personagens da narrativa.

Quanto às "funções e sequências narrativas de ordem comparativa e de disjunção", podemos notar que as narrativas jornalísticas que as contém podem mobilizar uma série de construções argumentativas e edificações de sentido diferentes: como similitude de causas, elas aludem a um passado cujas causas são as mesmas do presente e, podem, a partir disso, predizer um mesmo conjunto de conseqüência para o 
futuro; como analogia, estabelece-se uma similitude ou um afastamento de relações entre os dois tempos; enquanto quase-lógicas, o presente e o passado são cotejados a partir de raciocínios lógicos ou matemáticos que envolvem uma ideia de medição; entre outras construções destacadas.

Há, no entanto, alguns fatores que unificam e caracterizam os efeitos de sentido mobilizados por essas sequencias narrativas que põem em evidência a solidariedade ou a ruptura entre os acontecimentos do presente e determinados eventos do passado. Eles dizem respeito ao fato de que a relação entre o atual e o decorrido está situada na orientação que é dada à apreciação do interlocutor em relação a eles. Ou seja, confrontados textualmente, o presente e o passado participam de uma relação opositiva que constitui o que é (ou o que significa) o evento relatado da atualidade, de forma que é a comparação estabelece as tonalidades formativas.

A semantização do acontecimento jornalístico está articulada, nestas narrativas, a partir da assunção de que a descrição sobre o que é o fato atual (ou sobre o que ele significa) se torna inteligível a partir de determinadas referências a um decorrido que é engendrado como similar ou como diferente. Mais do que isso, ao formar uma imagem descritiva do presente a partir do passado, essas narrativas jornalísticas também argumentam em favor de algum tipo de entendimento a respeito do fato.

É a partir dessas reportagens que podemos afirmar que, ao evocar a história, as narrativas jornalísticas invocam um outro que constitui o presente.

Isso também pode ser dito, de uma maneira um pouco diferente, a respeito das "funções e sequências narrativas de origem" - que dizem respeito aos textos jornalísticos que remetem ao início ou às primeiras determinantes de um dado evento, tomando-os como fatores de explicação de seus desdobramentos na atualidade. E isso porque podemos notar que a remissão às origens funciona, muitas vezes, como uma estratégia argumentativa que ajuda a julgar a e ordenar.

Podemos encontrar uma série de reportagens em que a origem aludida semantiza o evento jornalístico na medida em que esta serve como um guia explicativo que engendra significações ligadas à demarcação das generalizações e ao fornecimento dos parâmetros a partir dos quais as possíveis soluções ou os possíveis culpados podem ser normativamente julgados.

Mesmo que esta noção de origem se constitua como um ponto de marcação arbitrário, não obstante isso, ela normalmente se fixa como um dos pontos fortes da narrativa, na medida em que atua em um esforço de eliminação de ambigüidades e desvios de sentido de um texto e cristaliza determinados nós de sentido. Estas injunções 
em torno de um evento histórico funcionam mesmo como uma espécie de símbolo - que estabelece os nós de sentido através das vinculações de coexistência simbólica que efetuam uma transferência entre o símbolo e o simbolizado - e não raro adquirem tonalidades essencialistas.

E é por isso que, ao evocar a história, o jornalismo invoca uma origem que descreve uma atualidade.

A partir desses resultados, nós podemos agora repensar o papel da memória nas estórias contadas pela imprensa, de forma a ampliar algumas das questões que unificam os diferentes tipos de funções e sequências narrativas que fazem remissão ao passado e para que possamos explorar como estes (enquanto lugares de memória) articulam lugares de sentido nas reportagens.

Muito embora estejamos lidando com um passado presentificado não podemos perder a noção de que a história se configura como um poderoso recurso de semantização para o jornalismo exatamente na medida em que ela ainda mantém o seu estatuto histórico, ou seja, na medida em que ele não perde a sua ancoragem no passado.

Isso pode ser visto a partir de diversos pontos de vistas, dos quais esmiuçaremos três: (1) a função exercida pelas narrativas e pela linguagem nesta presentificação; (2) a posição do passado como um terceiro no jogo das significações pré-articuladas nas narrativas jornalísticas e; (3) a questão das representações sociais e do reconhecimento. Estes são pontos que unem - apesar dos diferentes efeitos de sentido mobilizados bem como as diversas formas de tratamento - as funções e sequências narrativas que tratamos nos capítulos anteriores. Trata-se de questionamentos que serviram como pontos norteadores do trabalho como um todo e que temos agora a oportunidade de revisitar com maior atenção.

A respeito destas questões, podemos ter em mente por um segundo a sugestão de Walter Benjamin (2006: 504), para quem "não é o passado que lança sua luz sobre o presente ou que o presente lança sua luz sobre o passado; mas a imagem é aquilo em que o ocorrido encontra o agora num lampejo, formando uma constelação". Assim, "enquanto a relação do presente com o passado é puramente temporal e contínua, a relação do ocorrido com o agora é dialética - não é uma progressão, mas uma imagem que salta (...) e o lugar onde as encontramos é a linguagem”.

Entre várias outras questões importantes, a pergunta central que este trecho encerra é bastante sugestiva: falamos muito de representações históricas, mas estas, afinal, representam o que? Para tentarmos estabelecer o papel que este passado ocupa nas semantizações do fato jornalístico - enquanto apropriador de lugares de memória 
materializados em narrativas - é necessário que possamos perceber a forma como este passado é presentificado através dos mecanismos da narrativa e da linguagem.

De fato, esses enfrentamentos em torno do estatuto narrativo da história remetem a um questionamento fundamental, que é "como manter a diferença de princípio entre a imagem do ausente como irreal e a imagem do ausente como anterior?" (RICOEUR, 2007: 250). A questão da representação enquanto anterioridade confrontada com sua acepção enquanto invenção é ainda mais radicalizada com relação às representações da memória. Como um local de conjunção entre a história e a memória, os lugares de memória evocados pelo jornalismo em suas narrativas lidam com os problemas representacionais que concernem a estas duas esferas.

A noção comum que temos da memória remete mesmo à ideia de que ela diz respeito a uma anterioridade. Nós temos uma concepção corrente que pensa a memória de uma maneira bastante parecida com aquela que Aristóteles a pensou, como um ponto fixo e estável que está no passado e que imprime uma espécie de marca que é recuperável. Desde o século XIX, no entanto, - e muito especialmente a partir de meados do século XX -, essa concepção muda radicalmente e muitos autores passam a pensar a memória como um ponto demarcatório cujo significado pode ser eternamente manipulável.

Quando Aristóteles se perguntava como é possível recordar algo que não está presente (posto que está presente somente a impressão, mas não o fato), a dimensão de sua pergunta deve ser entendida dentro do contexto de que, para Aristóteles, a memória não pode ser entendida nem como uma sensação, nem como um juízo, mas sim, como um estado de afecção (pathos) destas coisas, uma vez que ela implica uma distância temporal entre o acontecido e a sua recordação. A memória, pertencendo àquele pedaço da alma no qual também está alocada a imaginação, está, portanto, sempre no passado, e implica, assim, um intervalo de tempo. "Por isso, só aqueles seres vivos que são conscientes do tempo podem dizer que se lembram e fazem isso com aquela parte da alma que é consciente do tempo" (ARISTÓTELES, 1962: 84).

Esta noção de uma memória enquanto afecção deve ser entendida tal como uma espécie de pintura mental (zographema) que é posta pela impressão de um fato. Ela parte de uma afecção causada na alma - "afecção cujo último estágio chamamos de memória" - por uma sensação que deixa uma marca, uma espécie de gravação. Este estímulo ou esta sensação "produz a impressão de uma espécie de semelhança do percebido", de maneira análoga à marca que é deixada na cera quando se fecha uma carta com um anel. 
É neste ponto que seu questionamento se impõe: se a memória se processa desta maneira, "do que é que uma pessoa se lembra: a afecção presente ou o objeto que deu origem a ela? (...) Se há em nós algo análogo a uma impressão ou a uma pintura, por que razão a percepção disto será memória ou recordação de algo distinto e não dele mesmo?" (ARISTÓTELES, 1962: 87).

Novamente sua resposta se impõe pela analogia entre a memória e a imagem. Da mesma forma que uma pintura sempre remete ao mesmo tempo a ela mesma e ao objeto representado, mesmo que ambos sejam essencialmente distintos, também a pintura mental que está dentro de nós deveria ser tomada tanto como um objeto de contemplação em si mesmo quanto como uma pintura mental de uma coisa distinta. $\mathrm{Ou}$ seja, ao reivindicar a categoria da alteridade da dialética platônica, Aristóteles remete à ideia de que "cabe à noção de inscrição comportar referência ao outro; o outro que não a afecção enquanto tal. A ausência, como o outro da presença!” (RICOEUR, 2007: 36). Quanto a este assunto, Ricoeur (2007: 36) observa mesmo que "aqui, o vocabulário de Aristóteles é preciso: ele reserva o termo phantasma à inscrição enquanto ela mesma, e o termo eikon para a referência a outra coisa que não a inscrição".

Assim, para Aristóteles (1962: 88), a memória "é um estado produzido por uma imagem mental, referida, como uma semelhança, a aquilo de que é imagem". Mais do que isso, ela pertence a uma faculdade bastante específica: à faculdade sensitiva primária, ou seja, "aquela com que percebemos o tempo". É importante, portanto, a distinção de que a memória sempre se refere a um passado. Nesta visão, "é, com efeito, impossível recordar o futuro, que é o objeto da conjectura e da espera (...) e tampouco há memória do presente enquanto ele é presente" (ARISTÓTELES, 1962: 83).

A distinção de que a memória é do passado é fundamental uma vez que marca toda uma inteligibilidade a respeito do ato de recordar, ultrapassando em muito o trabalho de Aristóteles ${ }^{67}$.

Essa outra noção de memória a que fizemos referência, no entanto, muda um pouco os termos em que essa recuperação de um passado ligado à memória coletiva era pensada e marca mesmo uma subversão deste princípio de que a memória diz respeito à anterioridade. A noção de memória enquanto invenção ganha primazia e passa a nortear

\footnotetext{
${ }^{67}$ Santos (2003) delineia as correntes sociológicas que consideram a memória como uma construção social relativa ao passado. Seu trabalho mostra que, de Halbwachs a Marcuse, as "diferentes abordagens filosóficas sobre a memória trabalharam basicamente com dois tipos de memória, duas formas de experiência ou consciência espaço-temporal, uma relacionada à percepção do passado em um determinado momento do presente e outra, a um processo contínuo de aprendizado" (SANTOS, 2003: 158). Mesmo com os diferentes tipos de atualizações no presente que estas memórias pudessem comportar, no entanto, o princípio fundamental de que a memória é do passado, mantém-se intacto.
} 
os estudos a respeito deste tema. Sobre este assunto, são bastante significativas as colocações de Jacques Derrida sobre a memória.

Em seu trabalho, o autor clama por uma nova inteligibilidade a respeito destes vestígios: a memória também como futuro. Ao iniciar seu trabalho em torno da memória de Paul de Man, Derrida afirma que "eu irei falar sobre o futuro (...) e como vocês poderão ver, o futuro não é exterior à memória; ele permanece afirmado na memória. Sim: afirmado" (DERRIDA, 1988: 19).

A noção de memória de Derrida se estrutura a partir da ideia de um luto impossível na medida em que ela está sujeita a ausência de um corpo, a um velório em defaut, marcado pela falta. A memória, neste sentido, não passa de um traço (grammé), ou seja, daquilo que "produz o espaço da sua inscrição senão dando-se o período da sua desaparição" (DERRIDA, 1995: 221).

De uma forma geral, o peso da memória não poderia ser separado, na obra de Derrida, do peso de se possuir um nome. Segundo suas próprias palavras, "a morte revela o poder do nome até a máxima extensão de que o nome continua a nomear ou a chamar o que nos chamamos de carregador do nome e que não pode mais responder à ou responder para e por seu nome" (DERRIDA, 1988: 49). Possuir um nome é, portanto, se sujeitar a uma eterna possibilidade de repetição deste nome no futuro, mesmo quando o nomeado não estiver mais presente. A partir de um funcionamento análogo, o ato de recordar, portanto, não é feito a partir da presença de um presente (o que significa que não se trata mais da ausência como o outro da presença), mas sim, de uma eterna presença da ausência, de uma presença feita de ausência.

Trata-se mesmo de um aspecto desde sempre posto no nome: "ao chamar ou nomear alguém durante a sua vida, nós sabemos que esse nome pode sobreviver a ele e já sobreviveu a ele; o nome começa durante a sua vida a dar-se sem ele, pronunciando e carregando a sua morte cada vez que é inscrito em uma lista, num registro civil, numa assinatura" (DERRIDA, 1988: 49).

A morte mostra o poder do nome porque faz com que se retenha apenas a memória e o nome, ou mais especificamente, a memória no nome e, neste sentido, não há mais como se pensar em uma memória pura: pode-se dizer apenas "em memória de". Para Derrida, não se pode separar memória e nome porque isso significa que quando se fala "em memória de", está-se referindo a um jogo duplo: significa tanto que o nome está em nossa memória (a partir da habilidade de evocar imagens e símbolos do passado) e que o nome está em si, fora, como um auxiliar exterior (tal como um monumento ou um símbolo erguido "em memória de"). 
A ambiguidade da memória está posta justamente aí: "a morte revela que o nome próprio pode sempre se prestar a repetições na ausência de quem o carrega, se tornando, deste modo, um nome singular tão comum quanto a pronúncia 'Eu', apagando, assim, a sua singularidade mesmo quando a designa" (DERRIDA, 1988: 50).

É a partir dessa ligação da memória ao nome que se pode subverter fundamentalmente a noção de que a memória é do passado. Isso porque assim como o nome, trata-se para Derrida, de uma memória que é sempre diferida (différance), sujeita ao mesmo jogo que está posto na linguagem.

Esse jogo remete ao fato de que a escrita ${ }^{68}$ implicaria dois tipos de diferenças: a différence (relacionada à alteridade dos signos, ou seja, ao fato já posto por Saussure de que um signo é aquilo que os outros signos não são e que ele tem apenas um valor relativo, ou seja, determinado por sua posição em relação a outros signos do sistema) e a différance (que diz respeito a uma temporização do signo em relação a outros, ou seja, a um retardamento, a um adiamento).

Sendo ao mesmo tempo diferencial e diferido, o sentido, como bem aponta Norris (1987: 15), "não está pontualmente presente em lugar algum na linguagem, ele está sempre sujeito a uma espécie de derrapagem (ou demora) semântica que impossibilita o signo de jamais (por assim dizer) coincidir consigo mesmo em um momento de apreensão perfeita, sem resíduos".

O mecanismo, grosso modo, é o seguinte: a linguagem, enquanto um sistema de signos, supõe uma duração e esta duração implica, por sua vez, uma inscrição de um traço que o constitui como diferente de todos os outros signos dentro de um sistema. $\mathrm{O}$ traço instituído já é uma escritura e disso se pode inferir que nenhuma linguagem é possível fora deste horizonte posto pela escritura. A noção de traço, portanto, está relacionada a estes desdobramentos da deriva imotivada dos signos. É a partir dela que Derrida pode subverter, em sua obra, algumas posições hierárquicas fundadoras (tais como fala e escrita) e instituir mesmo uma memória que não se refere ao passado (FERRO, 1992).

\footnotetext{
${ }^{68}$ A noção de escrita, dentro da obra de Derrida, é também bastante específica. A partir da desconstrução de uma tradição de pensamento que marginaliza a escrita em detrimento da fala, a concepção de escritura, ou de archi-escritura para Derrida, "é a escritura que se produz em jogo, na deriva sem fim da differance". Ou seja, "em um espaço constantemente diferido há uma escritura que funda a fala e a escrita. Fala e escrita, então, supõe uma archi-escritura como condição de possibilidade de toda a linguagem" (FERRO, 1992: 102). Nas palavras do próprio Derrida, “chamamos de 'escrita' tudo aquilo que dá origem a uma inscrição em geral, seja ou não literal ou mesmo se aquilo que ela distribui no espaço é alheio à ordem da voz: cinematografia, coreografia, naturalmente, mas também a 'escrita' pictórica, musical, escultural" (DERRIDA, 1976: 9).
} 
Essa noção de traço é essencial uma vez que indica o próprio movimento da différance: trata-se, ao mesmo tempo, "tanto propensão em direção a um futuro como retenção de um passado" (JOHNSON, 2001: 38). Sem uma origem ou início a que se possa fazer referência, os traços marcam sua presença com uma ausência, inaugurando, sempre, uma nova origem. Dentro do sistema de pensamentos derridiano, se lida sempre com um presente que se renova a todo instante.

Derrida inscreve o ato de recordar no mesmo mecanismo imposto pelo traço. $\mathrm{O}$ ato de dar nomes às coisas está sempre sujeito à sua inscrição em traços, sendo que estes marcam toda e qualquer inscrição no presente. Desta forma, não se pode falar, absolutamente de um resgate do passado, mas sim, no máximo, de uma narração do passado.

Uma vez que a memória é inseparável desta potencialidade de ressurreição do nome, ela está sempre limitada ao próprio ato presente que, no momento que surge, deixa de ser memória e passa a ser narrativa. Dessa forma, "a ideia de passado não existe no pensamento derridiano. O passado é apenas uma narração. (...) este fazer-se, essa instantaneidade é uma ilusão de que se traz o passado, pois a memória jamais o restitui, ao contrário, mostra que falta" (AMARAL, 2000: 35-36). É impossível, portanto, a recuperação deste passado.

Já que a legitimação da narrativa é dada somente no ato de recitar a si própria, ela é sempre contemporânea ao ato de contar histórias e, embora engendre uma expectativa de duração no tempo, ela não é a própria duração. Desta forma, "a memória em movimento não é mneme, a representação de um passado no presente; ela não tem um significado em si mesma e não pode afirmar-se a si própria no presente" (SANTOS, 2003: 165).

Mais do que isso: trata-se de um ato sempre voltado ao futuro. Da mesma forma que o traço, não se pode dizer da memória que esta tenha uma origem a que se possa fazer referência. Muito pelo contrário. Como já havíamos posto, a memória como traço inaugura a todo o momento uma nova origem ou um novo presente ${ }^{69}$.

Novamente podemos estabelecer um movimento análogo ao da linguagem. Ao falar um nome, o objeto que o carrega não precisa estar necessariamente presente, o que já marca uma falta. Derrida aponta, no entanto, uma falta a mais do que esta que já está

\footnotetext{
${ }^{69}$ Adriana Amaral resume muito bem esta noção quando afirma que: “a memória na verdade mostra que o passado falta e abre a possibilidade de repetição, sempre em diferença, no futuro. Não há mais como conceber um passado, porque afinal este nunca existirá, pois se algo já ocorreu estará sempre em simultaneidade com um presente que está sempre sendo elaborado, e se vai ocorrer no futuro, o que é apenas uma previsão, lá também ele será presente e não passado, ou seja, com a mesma performance" (AMARAL, 2000: 32).
} 
posta neste mecanismo básico da linguagem: trata-se da ausência do contexto. Isso significa que determinado enunciado continua a sua missão de comunicar em outros presentes no futuro, sendo que estes podem prevalecer sobre esse momento originário. Trata-se mesmo de uma sobreposição de futuros.

E é por isso que a memória, ao continuar sua missão de comunicar através da narração que a torna presente, é sempre um ato voltado a um presente e a um futuro que se sobrepõem, e nunca a um passado. Se no pensamento de Derrida, como bem coloca Amaral (2000: 41), “tudo está por vir e a ser repetido, sempre a partir do presente, só há presenças, onde passado, presente e futuro acontecem simultaneamente", a noção de que a memória é do passado sofre mesmo um deslocamento radical.

Em uma formulação belíssima, Derrida compara mesmo a memória a uma espécie de promessa não cumprida e impossível que se traduz em um ato - uma promessa que "só tem sentido e gravidade com a morte do outro". "Você pode chamá-la de um ato de memória ou de uma determinada palavra, mesmo um ato de fé; eu prefiro arriscar uma palavra mais arriscada e singular. Eu prefiro chamá-la de um ato, somente um ato, tão simplesmente um ato". Sendo talvez o único ato digno deste nome - uma vez que é feito em nome de um outro - a memória significaria em uma única sentença "donner au nom de l'autre" ou "une parole donnée au nom de l'autre". "Quem sabe o que nós estamos fazendo quando nós donnons au nom de l'autre?" (DERRIDA, 1988: 150).

O funcionamento de um resgate da memória social por parte da imprensa não poderia funcionar senão de modo análogo. Os dados históricos ali inseridos não dizem respeito aos próprios fatos, mas estão postos mesmo na condição de carregadores do nome de um fato histórico, de modo que se apaga a referência originária do evento no mesmo momento que o designa.

Podemos ver o próprio movimento da différance nesta memória evocada pela imprensa na medida em que, enquanto subproduto de um traço que repete sempre a diferencia, o seu significado comporta sempre determinados resíduos que indicam que ele está sempre em construção, sempre por se construir (desde a primeira vez em que ele foi narrado).

Ao serem carregadores de um nome, esses dados históricos estão mesmo postos em uma condição de eterna repetibilidade deste nome no futuro, bem como sua reinserção em diferentes contextos, de forma que o seu significado é mesmo eternamente manipulável. Eles não são mais do que traços, ou seja, elementos que 
inauguram uma nova origem e uma nova significação de um fato histórico a todo o momento.

E isso é muito facilmente percebível nas narrativas jornalísticas que evocam estes fatos históricos. Uma vez que a différance trazida pela memória "está baseada no movimento da informação em torno do circuito e não no armazenamento estático da informação" (JOHNSON, 2001: 41), podemos retomar, sob esta perspectiva, a lógica circular que envolve as narrativas jornalísticas que usam a história como estratégia de semantização do novo, ou seja, aquela implicada no fato de que a história funciona como um mapa cultural que circunscreve o acontecimento jornalístico ao mesmo tempo em que esse passado norteador é semantizado de acordo com a irrupção do novo.

Uma vez que a memória não tem significado em si mesma (ou, em outras palavras, se o seu sentido está em permanente construção) ela também já é inserida dentro de um quadro semântico da reportagem que, embora já esteja pré-constituído (no sentido de que está inserido dentro de um acontecimento jornalístico que já se manifestou como descontinuidade do continnum e que já foi posto em um determinado contexto de sentido), tem os sentidos também sujeitos a uma construção contínua já que também estão inseridos nos jogos semânticos da diferenciação.

Neste ato de recitar a si própria, as estratégias de semantização da narrativa jornalística devem ser entendidas mesmo como um processo sujeito a significações flutuantes e é sob esta mesma perspectiva que podemos entender como essas narrativas jornalísticas pesquisadas transformaram esse passado reconstruído no seu próprio ponto norteador, como se este fosse, em verdade, o construtor de seus lugares de sentido. Destituídos de suas referências originais, esses carregadores do nome de um fato histórico são rearticulados a esta pré-constituição dos eventos ao mesmo tempo em que se tornam um dos pontos de fixação da semantização deste acontecimento jornalístico relatado.

E sob essa perspectiva, a "pilhagem da história" de que nos fala Jameson (2006) - que se refere justamente a esta capacidade de aproveitar-se da história tudo o que nela se classifica como um aspecto do presente - não é propriamente um fenômeno recente ou pós-moderno. Essas remontagens do passado se referem mesmo às dificuldades próprias do dizer envolvidas nas reconstruções e recontextualizações do decorrido (e de suas relações com o presente), especialmente quando elas estão postas sob estes lugares que misturam as intenções memorialísticas às pretensões históricas, como são os lugares de memória mobilizados o tempo todo pelo jornalismo através de suas narrativas. 
Trata-se mesmo de uma característica das narrativas sobre o passado que, talvez por uma particularidade de uma sociedade que tenta "pensar historicamente o presente em uma época que já esqueceu como pensar dessa maneira"70 (JAMESON, 2006: 13) e, através das possibilidades postas pelos meios tecnológicos de comunicação e difusão de informações, tenha se exacerbado a ponto de percebermos com maior exatidão e a partir de uma maior extensão estas montagens que modificam e ressignificam o decorrido através de uma reorganização de seus elementos.

Trata-se de uma remontagem que está presente no trabalho dos media noticiosos o tempo todo - e com uma capacidade e velocidade de rearticulação que por vezes nos deixam atônitos. A semantização do fato jornalístico através dos dados históricos, vista sob esta perspectiva, diz respeito mesmo a este dar um nome ao outro, como diz Derrida. Mas, mais do que isso, se considerarmos o mecanismo exposto por Ricoeur, ao dar o nome e fazer ver, as narrativas jornalísticas também fazem este outro falar, de forma que ela diz o que este outro poderia dizer.

Ao manter um laço atado ao passado (mesmo levando-se em consideração esta derrapagem de sentidos que faz com que seus significados estejam sempre sob disputa e em construção), os dados históricos ocupam este lugar de um terceiro dentro das narrativas jornalísticas, de forma que sua posição está posta mesmo como uma posição de autoridade.

Como bem coloca Ricoeur (2007: 330), há mesmo uma vontade imaginária social de que a história ocupe o mesmo lugar de um juiz, no sentido de preencher a posição de um terceiro "em relação aos lugares ocupados no espaço público pelos protagonistas da ação social", como se esta pudesse ser posta fora de todo ponto de vista. Embora já tenhamos explorado bastante, no curso deste trabalho, esta posição social de uma suposta imparcialidade imaginária que a história ocupa, podemos ir além se considerarmos essa metáfora da história como juiz em sua posição de terceiro nas narrativas jornalísticas.

Como coloca Bloch (2001), existem dois modelos que podem ser tomados como ocupantes de um lugar de terceiro, cujas figuras exemplares são a do cientista e a do juiz, de forma que ambos estão comprometidos com uma forma de ver a realidade através de um julgamento imparcial. Elas se diferenciam, no entanto, pelo fato de que,

\footnotetext{
${ }^{70}$ É justamente esta a definição de pós-modernidade para Jameson. Segundo este autor, o pós-moderno deve ser pensado como um conceito que "ou exprime (não importa se de modo distorcido) um irreprimível impulso histórico mais profundo ou efetivamente o 'reprime' e desvia, dependendo de que lado da ambiguidade nos colocamos" (JAMESON, 2006: 13).
} 
ao passo em que o cientista se contenta com a observação e a explicação, ao juiz ainda cabe uma tarefa a mais: a declaração da sentença.

Tanto Bloch quanto Ricouer, bem como Certeau, concordam entre si de que muitas vezes a história foi posta como mais ligada a esta figura do juiz do que com a do cientista. As expectativas sociais coordenadas em torno do que o passado pode dizer sobre a sociedade contemporânea a colocam neste lugar de forma que ela funciona mesmo como ligada às normatividades. Também parece ser este o lugar que os dados históricos ocupam dentro da narrativa das revistas semanais e que delimitam o modo como eles funcionam como um dos elementos de semantização do acontecimento jornalístico.

“O juiz deve julgar - é a sua função. Ele deve concluir. Ele deve decidir. Ele deve instaurar uma justa distância entre o culpado e a vítima, segundo uma tipologia imperiosamente binária" (RICOUER, 2007: 335).

O que julga a história, então, quando ela está posta nas narrativas jornalísticas?

Ora, como coloca Certeau (2008: 107), a função simbolizadora da história "permite a uma sociedade situar-se, dando-lhe, na linguagem, um passado, e abrindo assim, e abrindo assim um espaço próprio para o presente". É, portanto, fazer ver uma imagem - ligada a um determinado tipo de entendimento - dos eventos da atualidade, que está em jogo neste julgamento que a história carrega nas narrativas jornalísticas.

E assim, "marcar um passado, é dar lugar à morte, mas também redistribuir o espaço das possibilidades, determinar negativamente aquilo que está por fazer e, consequentemente, utilizar a narratividade, que enterra os mortos como um meio de estabelecer um lugar para os vivos". Desta forma, "a arrumação dos ausentes é o inverso de uma normatividade que visa o leitor vivo e que instaura uma relação didática entre o remetente e o destinatário" (CERTEAU, 2008: 107).

Ao exorcizar o passado e instaurar a morte no texto, os dados históricos funcionam nas narrativas jornalísticas como pequenos túmulos que "substituem pedagogicamente alguma coisa que o leitor deve crer e fazer". A reconstrução deste morto em um lugar simbólico, como coloca Certeau, cria no presente um lugar a preencher - que pode ser tanto no passado quanto no futuro - que instaura um "dever fazer" ou um "dever crer", de forma que libera o presente sem ter que nomeá-lo explicitamente.

"Nomear os ausentes da casa e introduzi-los na linguagem escrituraria é liberar o apartamento para os vivos, através de um ato de comunicação, que combina a ausência dos vivos na linguagem com a ausência dos mortos na casa" (CERTEAU, 2008: 108). 
É assim que a história ocupa um papel de exorcismo contra a angústia nas narrativas jornalísticas: ela funciona como simbolização para o desejo que constitui a relação da atualidade com o seu outro. Para Certeau, ela é mesmo a marca desta lei, de forma que "a linguagem permite a uma prática situar-se com relação a seu outro, o passado", de forma que ela efetua uma nova distribuição das práticas já semantizadas. Como se os mortos se tornassem o vocabulário de uma tarefa a empreender.

Em termos mais banais, a história funciona mesmo como uma arma contra a angústia na medida em que consegue circunscrever e enquadrar o novo, que, por sua vez, poderia representar o próprio desconhecido não fosse a sua presença.

E é neste sentido que a história se posiciona também como um juiz: atada ao jogo das representações que um corpo social mantém com a sua linguagem, a narrativa histórica inserida no jornalismo "caminha entre a blasfêmia e a curiosidade, entre aquilo que elimina, constituindo-o como passado, e aquilo que organiza do presente, entre a privação ou a desapropriação postulada pela normatividade social que ela impõe ao leitor, à sua revelia" (CERTEAU, 2008: 109). E, mais do que isso, ao se portar como juiz, é como se estes mortos fossem mesmo capazes de proferir sentenças a partir desta normatividade postulada.

Esta questão está obviamente relacionada à noção de este outro (ou este terceiro) ligado à história, enquanto prática discursiva, diz respeito ao delineamento de algo que estabelece vínculos societários e que, consequentemente, se relaciona com o jogo das representações sociais e, em certo sentido, com as próprias identificações coletivas. Como lembra Gomes (2008: 70), “a identificação é um processo pelo qual algo (sempre um traço e não o conjunto) do modelo criado como ideal de eu é visto em outro lugar, lugar então que atrai como função de realização do ideal". E assim, "no caso da formação de grupos, essa analogia significante é baseada numa qualidade emocional comum". Mais do isso, "as identificações nos protegem dando-nos um respaldo social" e "dentre essas implicações, a mais forte e poderosa talvez seja o oferecimento de discursos prontos que são assumidos como legitimadores" (GOMES, 2008: 77-78) de uma determinada forma de ver o mundo.

Ora, de acordo com Ricouer (2007) esta maneira de estabelecer uma identificação com a história pela mediação das representações sociais se processa em torno da temática de um reconhecimento que estabelece ou repara uma falta. Vejamos como.

Segundo este autor, há mesmo um "pequeno milagre" que sempre circunda a noção da memória: trata-se do milagre do reconhecimento que faz com que, diante de 
um passado evocado, possa sobrevir em um instante a exclamação “é ela, é ele!". Neste sentido, "a vinda de uma lembrança é um acontecimento" (2007: 508).

Utilizando as palavras do próprio autor, quando este acontecimento se produz "sob os dedos que folheiam um álbum de fotos, quando do encontro inesperado com uma pessoa conhecida, ou quando da evocação silenciosa de um ser ausente ou desaparecido para sempre", é aí que podemos conceber que "todo o fazer-memória resume-se assim no reconhecimento". E isso porque "a mesma saudação [“é ela, é ele'] acompanha gradualmente, sob cores menos vivas, um acontecimento rememorado, uma habilidade reconquistada, um estado de coisas de novo promovido à "recognição", (RICOEUR, 2007: 502).

E é justamente aí que o reconhecimento se processa com toda a sua força: ele se apoia mesmo em suportes materiais ou em apresentações figuradas uma vez que é na representação que se induz a identificação com a coisa retratada em sua ausência.

Assim, da mesma forma que a verdade se estrutura tal como um voto (que pode ser cumprido, frustrado ou traído) este tipo de reconhecimento - que, quando acontece, o autor chama de "memória feliz" - também se apresenta sob a forma de uma reivindicação (um claim) que está sempre marcada por uma aporia. Esta, que diz respeito a todos os tipos de evocações do passado, está posta sob a forma de "uma representação presente de uma coisa ausente marcada pelo selo da anterioridade, da distância temporal".

Isso tem algumas implicações importantes. No caso da questão do reconhecimento, podemos pensar que estas narrativas carregam mesmo os problemas da tríade "memória-julgamento-ação" (RICOEUR, 2006). Isto porque a questão do reconhecimento está relacionada diretamente ao problema do perdão e do esquecimento.

Dentro da perspectiva de Ricoeur, os grandes traumas coletivos da história podem sofrer uma espécie de processo de perdão como um tipo de troca, que dá lugar a retribuições, a reparações ou a absolvições. Neste sentido, obviamente, é necessário uma espécie de reconhecimento da ação, de um reconhecimento de que a troca foi efetuada.

Para Ricoeur (2006: 143), “a promessa, ligada ao perdão, permite que a 'ação' humana continue: ao 'desligar' o perdão responde à irreversibilidade que arruína a capacidade de responder de modo responsável às consequências da ação; o perdão é que torna possível a reparação". Do mesmo modo, o contrário também é válido: "ao ligar, a promessa responde à imprevisibilidade que arruína a confiança em um curso esperado de ação, tornando-se pano de fundo da confiabilidade do agir humano". 
Estas questões do reconhecimento, neste sentido, parecem mesmo estar fortemente imbricadas nas narrativas jornalísticas que utilizam dados históricos em sua composição. Também dizemos "'é ele' 'é ela" quando folheamos as páginas das revistas e nos deparamos com o decorrido. Podemos encontrar exemplos claros disso em todos os tipos de funções e sequências narrativas que estudamos.

Nas narrativas de trajetórias pessoais, por exemplo, o julgamento da ação ou do testemunho diz respeito a um reconhecimento do comprometimento moral daquele que age ou daquele que fala. Também nas funções e sequências narrativas de ordem comparativa e de disjunção, na medida em que é a comparação que estrutura o modo como o evento é constituído, a partir de um jogo de oposições, é o passado que fornece o enquadramento (sempre através de um reconhecimento deste outro que não o presente) sobre os contornos de entendimento do evento. Isso também é válido para as funções e sequências narrativas de origem, na medida em que estas se estruturam justamente a partir do reconhecimento de um símbolo forte que estrutura a narrativa e fornece modelos explicativos.

Mais do que isso, é necessário - para que os efeitos de sentido mobilizados por estas funções e sequências narrativas "funcionem" nas reportagens - que eu possa reconhecer aquele passado evocado como meu (ou como do outro) para que as normatividades evocadas possam ser acionadas.

O que está em jogo aqui, portanto, é a noção de que este pequeno milagre da memória (o reconhecimento) é mobilizado na urdidura de enredo das reportagens jornalísticas e é justamente esta mobilização que desenha os contornos de sentido. Ligada à tríade "memória-julgamento-ação", é o conteúdo que encerra este "é ele", "é ela" que determina certas direções de entendimento em torno do noticiado, na medida em que ele instaura ou uma falta ou uma reparação.

Ora, para Ricoeur (2006: 153) este estabelecimento do reconhecimento está ligado ao jogo das identificações na medida em que ele "está no nível das representações coletivas que mediatizam a instauração do vínculo social", de modo que o reconhecimento não abarca apenas um julgamento imparcial em torno do relatado, mas está relacionado mesmo a vínculos emocionais que são urdidos em torno da significação de um acontecimento, ligando este reconhecimento ao estabelecimento das identidades coletivas ${ }^{71}$.

\footnotetext{
${ }^{71}$ Gomes (2009: 104-105) lembra que as identificações são um processo intrínseco às representações sociais. "Reconhece-se, assim, que a construção das representações sociais é dimensionada por um processo de identificação que opera por eleição de uma característica comum. Reconhece-se a constituição de identidade como produção fundada nos discursos em que fomos educados, ou com os
} 
Se, como coloca Ducrot (2009: 11), o outro tem sempre uma natureza constitutiva "porque é somente através dele que posso me ver e é através de seu reconhecimento que posso me reconhecer", ao funcionar como este comum que nos correlaciona em um vínculo societário, o passado inserido nas narrativas jornalísticas funciona mesmo como este outro que nos liga a um jogo das representações sociais e faz com que possamos reconhecer um presente porque posto em relação a um decorrido. E reconhecer, neste caso, está intimamente relacionado ao ato de julgar.

A comparação ou o estabelecimento de uma origem, dentro das narrativas jornalísticas, não diz respeito, neste sentindo, a algo que esteja posto no próprio evento da atualidade relatado. Diz respeito, sim, às formas a partir das quais imprimimos sentido ao mundo e nos posicionamos frente aos acontecimentos.

Por estas razões que procuramos demonstrar, ao longo do trabalho, que ao evocar a história, as narrativas jornalísticas acabam por invocar muitas coisas. Elas podem invocam uma estratégia referencial, um comum, um posicionamento para os personagens da narrativa, um outro que constitui um presente, uma origem que descreve uma atualidade. E tudo isso pode ser resumido na noção de que, ao evocar a história, o jornalismo invoca a edificação de lugares de sentido para as estórias tecidas.

quais temos contato, ou ainda o que nos são oferecidos como opções nas formatações discursivas de uma época. São estes que vêm a determinar as posições do sujeito". 


\section{REFERÊNCIAS BIBLIOGRÁFICAS}

ABRAMO, Claudio. A regra do jogo. São Paulo: Companhia das Letras, 1988.

AMARAL, Adriana Cörner Lopes do. "Sobre a memória em Jacques Derrida". In NASCIMENTO, Evandro e GLENADEL, Paula (org.). Em Torno de Jacques Derrida. Rio de Janeiro: 7Letras, 2000.

ANGRIMANI, Danilo. Espreme que sai sangue: um estudo do sensacionalismo na imprensa. São Paulo: Summus, 1995.

ANTUNES, Elton e VAZ, Paulo Bernardo. "Mídia: um aro, um halo e um elo". In GUIMARÃES, César e FRANÇA, Vera (org.). Na mídia, na rua: narrativas do cotidiano. Belo Horizonte: Autêntica Editora, 2006.

ARENDT, Hannah. Entre o passado e o futuro. São Paulo: Perspectiva, 2007.

ARISTÓTELES. De la Memoria y el Recuerdo. Buenos Aires: Aguilar, 1962.

ARISTÓTELES. Poética. Barcelona: Icaria, 2000.

ARISTÓTELES. Retórica. São Paulo: Rideel, 2007.

BACKSCHEIDER, Paula. Reflections on Biography. New York: Oxford University Press, 2002.

BARTHES, Roland. "Introdução à Análise Estrutural da Narrativa". In Análise Estrutural da Narrativa. Rio de Janeiro: Vozes, 1976.

BARTHES, Roland. O Rumor da Língua. São Paulo: Brasiliense, 1988.

BANN, Stephen. As invenções da História: ensaios sobre a representação do passado. São Paulo: Editora da UNESP, 1994.

BELTRÃO, Luiz. Jornalismo Interpretativo: filosofia e técnica. Porto Alegre: Sulina, 1976.

BENJAMIN, Walter. Passagens. Belo Horizonte, São Paulo: Editora da UFMG e Imprensa Oficial, 2006.

BERNARDO, Gustavo. O Livro da Metaficção. Rio de Janeiro: Tinta Negra, 2010.

BLOCH, Marc. "Memória coletiva, tradição e costume: a propósito de um livro recente". In BLOCH, Marc. História e Historiadores: textos reunidos por Étienne Bloch. Lisboa: Editorial Teorema, 1998.

BLOCH, Marc. Apologia da História ou O Ofício do Historiador. Rio de Janeiro: Jorge Zahar, 2001.

BOAS, Sergio Vilas. Biografias e Biógrafos: jornalismo sobre personagens. São Paulo: Summus, 2002.

BOND, Frank Fraser. Introdução ao Jornalismo. Rio de Janeiro: Agir Editora, 1959.

BOURDIEU, Pierre. "A Ilusão Biográfica". In FERREIRA, Marieta e AMADO, Janaína. Usos e Abusos da História Oral. Rio de Janeiro: Editora da Fundação Getulio Vargas, 1996.

BRAUDEL, Fernand. Reflexões sobre a História. São Paulo: Martins Fontes, 1992.

BREMOND, Claude. "A Lógica dos Possíveis Narrativos". In Análise Estrutural da Narrativa. Rio de Janeiro: Vozes, 1976.

BRETON, Philippe. A Argumentação na Comunicação. Bauru: EDUSC, 1999.

BUCCI, Eugênio. Televisão Objeto: a crítica e suas questões de método. Tese de doutorado apresentada à Escola de Comunicação e Artes da Universidade de São Paulo. São Paulo: ECAUSP, 2002.

BURKE, Peter. A Arte da Conversação. São Paulo: UNESP, 1995.

BURKE, Peter. "A invenção da biografia e o individualismo renascentista". Estudos Históricos. Número 19. Rio de Janeiro: CPDOC, 1997, p.1-14.

CALligaRIS, Contardo. "Verdades de autobiografias e diários íntimos". Estudos Históricos. Volume 11, número 21, Rio de Janeiro: CPDOC, 1998, p. 43-58.

CARR, Edward Hallet. Que é História?. Rio de Janeiro: Paz e Terra, 2002.

CARTA, Mino. "Carta ao Leitor". Veja. 08/04/1970, p. 17. Disponível em <http://veja.abril.com.br/acervodigital/home.aspx>. Acesso em 06/06/2009.

CARULA, Karoline. "O darwinismo nas Conferências Populares da Glória". Revista Brasileira de História. Volume 28, número 56, São Paulo, 2008. 
CASTILHO, Carlos. "Contexto, a nova palavra-chave do jornalismo". Observatório da Imprensa, Campinas, 16 de Março de 2007. Disponível em http://observatorio.ultimosegundo.ig.com.br/blogs.asp?id=\%7B6B53F909-D7C9-43BE-82182CACE3A9CFCC\%7D\&id_blog=2. Acesso 13/12/2009.

CERTEAU, Michel de. A Escrita da História. Rio de Janeiro: Forense Universitária, 2008.

CHARAUDEAU, Patrick. Discurso das Mídias. São Paulo: Contexto, 2006.

CRIPPA, Marcos (org.). Entrevista e ética: uma introdução. São Paulo: Educ, 1998.

CZERESNiA, Dina e AlbUQUERQUE, Maria de Fátima Militão de. "Modelos de interferência causal: análise crítica da utilização da estatística na epidemiologia". Revista de Saúde Pública, volume 29, número 05, São Paulo, Outubro de 1995.

DERRIDA, Jacques. On Grammatology. Maryland: John Hopkins University Press, 1976.

DERRIDA, Jacques. Memoires for Paul de Man. Nova York: Columbia University Press, 1988.

DERRIDA, Jacques. A Escritura e a Diferença. São Paulo: Perspectiva, 1995.

DERRIDA, Jacques. "Fé e Saber: as duas fontes da 'religião' nos limites da simples razão". In

DERRIDA, Jacques e VATTIMO, Gianni (dir.). A Religião: seminário de Capri. Lisboa: Relógio D'Água, 1997.

DOSSE, François. A História. Bauru, São Paulo: EDUSC, 2003.

DUCROT, Oswald. Princípios da Semântica Linguística (dizer e não dizer). São Paulo: Cultrix, 1972.

DUCROT, Oswald. O Dizer e o Dito. Campinas: Pontes, 1987.

DUCROT, Oswald. "Prefácio". In VOGT, Carlos. O Intervalo Semântico: contribuição para uma Teoria Semântica Argumentativa. São Paulo: Ateliê Editorial, Editora da Unicamp, 2009.

DUCROT, Oswald e TODOROV, Tzvetan. Dicionário Enciclopédico das Ciências da Linguagem. São Paulo: Perspectiva, 2007.

EDY, Jill. "Journalistic Uses of Collective Memory". Journal of Communication, volume 49, número 2, 1999, p. 71-85.

FARIA, Isabel Hub. "Mulheres agentes de discurso: alguns aspectos das orientações para os significados". Análise Social. Volume XXII, número 3-4, 1986, p. 547-555.

FERREIRA, Aurélio Buarque de Holanda. Minidicionário da Língua Portuguesa Aurélio. Rio de Janeiro: Nova Fronteira, 1993.

FERRO, Roberto. Estrutura y Desconstrucción. Buenos Aires: Biblos, 1992.

FIORIN, José Luiz. "A Linguagem em Uso". In: FIORIN, José Luiz (org.). Introdução à Linguística: objetos teóricos. São Paulo: Contexto, 2002.

FIORIN, José Luiz. Elementos de Análise do Discurso. São Paulo: Contexto, 2005.

FOLHA DE SÃO PAULO. "Editorial: Triste Justiça". FSP, 02/08/2009. Disponível em <http://www1.folha.uol.com.br/fsp/opiniao/fz0208200901.htm>. Acesso 07/08/09.

FOLHA DE SÃO PAULO. "Editorial: a escolha do Planalto". FSP, 20/04/2009. Disponível em < http://www1.folha.uol.com.br/fsp/opiniao/fz2004200901.htm>. Acesso 07/08/2009.

FORTES, Rafael. "O presidente e a democracia: o passado de José Sarney em IstoÉ e Veja". Revista da Associação Nacional dos Programas de Pós-Graduação em Comunicação. Compós, ano 3, volume 5, abril de 2006.

FOUCAULT, Michel. A Ordem do Discurso. São Paulo: Loyola, 1996.

FRANCISCATO, Carlos Eduardo. "A atualidade no jornalismo". In HOHLFELDT, Antonio et alli. Práticas midiáticas e espaço público. Porto Alegre: EDIPUC-RS, 2001.

FRANSCISCATO, Carlos Eduardo. A atualidade no jornalismo: bases para sua delimitação teórica. Tese de doutorado defendida na Universidade Federal da Bahia. Salvador: UFBA, 2003.

FRANCISCATO, Carlos Eduardo. A Fabricação do Presente: como o jornalismo reformulou na experiência do tempo nas sociedades ocidentais. São Cristovão: Editora da UFS, 2005.

G1 NOTÍCIAS. "Tarso não vê 'aumento da violência' em ações do MST". Disponível: http://g1.globo.com/Noticias/Brasil/0,,MUL1024309-5598,00-

TARSO+GENRO+NAO+VE+AUMENTO+DA+VIOLENCIA+EM+ACOES+DO+MST.html. Publicação em 02/03/2009. Acesso em 21/10/2009. 
GAZZOTTI, Juliana. Imprensa e Ditadura: a revista Veja e os governos militares (19681985). Dissertação de mestrado apresentada à Universidade Federal de São Carlos. São Carlos: UFSCAR, 1999.

GEERTZ, Clifford. A interpretação das culturas. Rio de Janeiro: Jorge Zahar, 1978.

GINER, Salvador. "Prólogo". In MARRAMAO, Giacomo. Poder e Secularização: as categorias do tempo. São Paulo: Editora da UNESP, 1995.

GOMES, Mayra Rodrigues. Poder no Jornalismo: discorrer, disciplinar, controlar. São Paulo: Hacker Editores, Edusp, 2003.

GOMES, Mayra Rodrigues et alli. Palavras Proibidas: pressupostos e subentendidos na censura teatral. São José do Rio Preto: Bluecom, 2008.

GOMES, Mayra Rodrigues. Comunicação e Identificação: ressonâncias no jornalismo. São Paulo: Ateliê Editorial, 2009.

GREGOLIN, Maria do Rosano Valencise. "Discurso e Memoria: Movimentos na Bruma da Historia”. In: Cadernos da Faculdade de Filosofia e Ciencias. Marilia: UNESP, 1997, p. 45-58.

GREIMAS, Algirdas Julien e COURTÉS, Joseph. Dicionário de Semiótica. São Paulo: Cultrix, 1979.

HABERMAS, Jürgen. Mudança Estrutural da Esfera Pública: investigações quanto a uma categoria da sociedade burguesa. Rio de Janeiro: Tempo Brasileiro, 1984.

HALL, Stuart. "A produção social das notícias: o mugging nos media". In TRAQUINA, Nelson (org.). Jornalismo: questões, teorias e estórias. Lisboa: Vega, 1993.

HALBWACHS, Maurice. Les Cadres Sociaux de la Mémoire. Paris: Albin Michel, 1994.

HALBWACHS, Maurice. A Memória Coletiva. São Paulo, Centauro: 2006.

HAMON, Philippe. "Para um estatuto semiológico da personagem". In GURYON, Françoise van Rossum. Categorias da Narrativa. Lisboa: Arcadia, 1976.

HAMON, Philippe. "Texte littéraire et métalangage". Poétique, número 31. Paris: Seuil, Setembro de 1977.

HERODOTO. Histórias. Brasília: Editora UNB, 1985.

HOBSBAWM, Eric. Sobre História. São Paulo: Companhia das Letras, 2005.

HUYSSEN, Andreas. "Resistência à Memória: os usos e abusos do esquecimento público". In BRAGANÇA, Aníbal e MOREIRA, Sônia Virgínia (org.). Comunicação, Acontecimento e Memória. São Paulo: Intercom, 2005.

HUXFORD, John. It's the end of the world as we know it: journalism and the prediction of catastrophe. Tese de doutorado apresentada à Universidade da Pensilvânia, 2004.

JAMESON, Frederic. Pós-modernismo: a lógica cultural do capitalismo tardio. São Paulo: Ática, 2006.

JANNUZZI, Paulo de Martino. "A formação em estatística do pesquisador social no Brasil: notas para discussão". Atas da Conferência Internacional 'Experiências e Expectativas do Ensino de Estatística: desafios para o século XXI'. Florianópolis, 20 a 23 de Setembro de 1999.

JASMIN, Marcelo. "Apresentação". In KOSELLECK, Reinhart. Futuro Passado: contribuição à semântica dos tempos históricos. Rio de Janeiro: Contraponto, Editora PUC-Rio, 2006.

JOHNSON, Christopher. Derrida: a cena da escritura. São Paulo: Editora da UNESP, 2001.

KARAM, Francisco José Castilhos. A Ética jornalística e o interesse público. São Paulo: Summus, 2004.

KARAM, Francisco José Castilhos. "O presente possível do jornalismo". Estudos em Jornalismo e Mídia, volume II, número 02, 2005, p. 75-81.

KEHL, Maria Rita. "Psicanálise \& Mídia: você decide... e Freud explica". In CHALHUB, Samira (org.). Psicanálise e o contemporâneo. São Paulo: Hacker, 1996.

KITCH, Carolyn. Pages from the Past: history \& memory in american magazines. North Carolina: The University of North Carolina Press, 2005.

KOLLERITZ, Fernando. "Testemunho, juízo político e história". Revista Brasileira de História. Volume 24, número 48. São Paulo: ANPUH, 2004, p.73-100.

KOSELLECK, Reinhart. Futuro Passado: contribuição à semântica dos tempos históricos. Rio de Janeiro: Contraponto, Editora PUC-Rio, 2006. 
KOTSCHO, Ricardo. A prática da reportagem. São Paulo: Ática, 1986.

KRISTEVA, Julia. $O$ texto do romance: estudo semiológico de uma estrutura discursiva transformacional. Lisboa: Horizonte, 1984.

LAGE, Nilson. A reportagem: teoria e técnica de entrevista e pesquisa jornalística. Rio de Janeiro: Record, 2008.

LE GOFF, Jacques. História e Memória. Campinas: Editora da Unicamp, 2003.

LEVI, Giovanni. "Usos da Biografia". In AMADO, Janaína e FERREIRA, Marieta de Moraes (coord.). Usos \& Abusos da História Oral. Rio de Janeiro: Editora da Fundação Getúlio Vargas, 1998.

MAINGUENEAU, Dominique. Novas tendências em análise de discurso. Campinas: Pontes, 2002.

MAINGUENEAU, Dominique. Cenas da Enunciação. São Paulo: Parábol Editorial, 2008.

MAQUIA VEL, Nicolau. O Príncipe. São Paulo: Editora Nova Cultural, 1996.

MARCONDES FILHO, Ciro. Comunicação e jornalismo: a saga dos cães perdidos. São Paulo: Hacker Editores, 2000.

MARRAMAO, Giacomo. Poder e Secularização: as categorias do tempo. São Paulo: Editora da UNESP, 1995.

MARTINS, Eduardo (org.). Manual de Redação e Estilo d'O Estado de São Paulo. São Paulo: Moderna, 2003.

MEDITSCH, Eduardo. “O jornalismo é uma forma de conhecimento?". Porto: BOCC, 1997.

MORIN, Edgar. "A entrevista nas ciências sociais, no rádio e televisão". In MOLES, Abraham (org.). Linguagem da Cultura de Massa. Petrópolis: Vozes, 1973.

MORRIS-SUZUKI, Tessa. The Past withing us: media, memory, history. London: Verso, 2005.

MOTTA, Luiz Gonzaga. "Análise pragmática da narrativa jornalística”. In LAGO, Cláudia, BENETTI, Márcia. Metodologia de pesquisa em jornalismo. Petrópolis: Vozes, 2008.

MOUILLAUD, Maurice e PORTO, Sérgio. $O$ jornal: da forma ao sentido. Brasília: Editora UNB, 2002.

MOURA, Maria Betânia. Os nós da teia: desatando estratégias de faticidade jornalística. São Paulo: Annablume, 2006.

NOBLAT, Ricardo. A arte de fazer um jornal diário. São Paulo: Contexto, 2004.

NORA, Pierre. Realms of Memory: the construction of the French Past (volume I: Conflicts and Divisions). Nova Iorque: Columbia University Press, 1996 .

NORRIS, Christopher. Derrida. Cambridge: Harvard University Press, 1987.

OSSOWSKI, Stanislaw. Estrutura de classes na consciencia social. Rio de Janeiro: Zahar, 1964.

PENA, Felipe. Teorias do Jornalismo. São Paulo: Editora Contexto, 2005.

PERELMAN, Chaïm. Retóricas. São Paulo: Martins Fontes, 1997.

PERELMAN, Chaïm e OLBRECHTS-TYTECA, Lucie. Tratado de Argumentação: a nova retórica. São Paulo: Martins Fontes, 1996.

PIGNATARI, Décio. "Para uma semiótica da biografia". In HISGAIL, Fani (org.). Biografia: sintoma da cultura. São Paulo: Hacker, CESPUC, 1996.

POLLAK, Michael. "Memória, esquecimento, silêncio". Estudos Históricos. Volume 2, número 3. Rio de Janeiro: CPDOC, 1989, p. 3-15.

PROST, Antoine. Doze lições sobre a História. Belo Horizonte: Autêntica, 2008.

RESENDE, Fernando. "O jornalismo e a enunciação: perspectivas para um narradorjornalista". Livro da XIV Compós. Rio de Janeiro, 2005.

RIBEIRO, Flávia. "Favelas cariocas: a cidade e os morros". Aventuras na História, edição 076, novembro de 2009. Disponível em http://historia.abril.com.br/politica/fave

las-cariocas-cidade-morros-435499.shtml. Acesso em 16/12/2009.

RIBEIRO, Lavina. Imprensa e Espaço Público: a institucionalização do jornalismo no Brasil (1808-1964). Rio de Janeiro: E-Papers, 2004.

RICOEUR, Paul. Tempo e Narrativa. Tomo I. Campinas, São Paulo: Papirus, 1994.

RICOEUR, Paul. Percurso do Reconhecimento. São Paulo: Loyola, 2006. 
RICOEUR, Paul. A Memória, a História, o Esquecimento. Campinas: Editora da Unicamp, 2007.

RODRIGUES, Adriano. "O Acontecimento". Revista de Comunicação e Linguagens, número 8, Lisboa, 1988.

SALIBA, Elias Thomé. "As imagens canônicas e a História”. In CAPELATO, Maria Helena, MORETTIN, Eduardo, NAPOLITANO, Marcos e SALIBA, Elias Thomé (org.). História e Cinema. São Paulo: Alameda, 2007.

SANTOS, Myrian Sepúleda dos. Memória Coletiva e Teoria Social. São Paulo: Annablume, 2003.

SAPERAS, Eric. Os Efeitos Cognitivos da Comunicação de Massas. Porto: Edições Asa, 1993. SARTRE, Jean Paul. O Ser e o Nada: ensaio de ontologia fenomenológica. Petrópolis: Vozes, 2005.

SCALZO, Marilia. Jornalismo de Revista. São Paulo: Contexto, 2003.

SCHNEIDER, Daniela Ribeiro. "A Náusea e a psicologia clínica: interações entre literatura e filosofia em Sartre". Estudos e Pesquisa em Psicologia. Volume 6, número 2. Rio de Janeiro: 2006, p.51-61.

SCHUDSON, Michael. "Deadlines, datelines and History". In SCHUDSON, Michael e MANOFF, Robert Karl (ed.). Reading the News: a pantheon guide to popular culture. New York: Pantheon Books, 1987, p. 79-108.

SELIGMANN-SILVA, Márcio. "O testemunho: entre a ficção e o real". In SELLIGMANNSILVA, Márcio (org.). História, Memória, Literatura: o testemunho na era das catástrofes. Campinas: Editora da Unicamp, 2003.

SERVA, Leão. Jornalismo e Desinformação. São Paulo: Editora Senac, 2001.

SETERS, John van. Em Busca da História: historiografia no mundo antigo e as origens da história bíblica. São Paulo: Edusp, 2008.

SETZER, Valdemar W. Os Meios Eletrônicos e a Educação: Uma Visão alternativa. São Paulo: Escrituras, 2001.

SILVA, Carlos Eduardo Lins da. $O$ adiantado da hora: a influência americana sobre o jornalismo brasileiro. São Paulo: Summus, 1990.

SOARES, Rosana Lima. Imagens veladas: aids, imprensa e linguagem. São Paulo: Annablume, 2001.

SOARES, Rosana de Lima. "No rastro do discurso: para pensar a comunicação". Revista Rumores, volume 1, número 3, Julho- Dezembro de 2008.

SODRÉ, Muniz. A narração do fato: notas para uma teoria do acontecimento. Petrópolis: Vozes, 2009.

SODRÉ, Muniz e FERRARI, Maria Helena. Técnica de Reportagem: notas sobre a narrativa jornalística. São Paulo: Summus, 1986.

SODRÉ, Nelson Werneck. A História da Imprensa no Brasil. Rio de Janeiro, Mauad, 1999.

SORLIN, Pierre. "Televisão: outra inteligência do passado". In NÓVOA, Jorge, et alli (orgs.). Cinematógrafo: um olhar sobre a história. Salvador, São Paulo: UFBA, Editora da UNESP, 2009.

SOUSA, Jorge Pedro. Teorias da notícia e do jornalismo. Chapecó: Argos, 2002.

THOMPSON, John B. Ideologia e Cultura Moderna. Petrópolis: Vozes, 1995.

THOMPSON, John B. A mídia e a modernidade: uma teoria social da mídia. Petrópolis: Vozes, 1998.

TITO LÍVIO. "Ad Urba Condita”. In HARTOG, François. A História de Homero a Santo Agostinho. Belo Horizonte: Editora da UFMG, 2001.

TOCQUEVILLE, Alexis de. Democracy in America. Cambridge: Sever and Francis, 1863.

TODOROV, Tzvetan. "As Categorias da Narrativa Literária". In Análise Estrutural da Narrativa. Rio de Janeiro: Vozes, 1976.

TODOROV, Tzvetan. Memória do Mal, Tentação do Bem: indagações sobre o século XX. São Paulo: Arx, 2002.

TOGNOLLI, Cláudio Júlio. Falácia Genética: a ideologia do DNA na imprensa. São Paulo: Escrituras, 2003. 
TRAQUINA, Nelson. Teorias do Jornalismo. Por que as notícias são como são. Florianópolis: Insular, 2005a.

TRAQUINA, Nelson. Teorias do jornalismo. A tribo jornalística - uma comunidade interpretativa transnacional. Florianópolis: Insular, 2005b.

TRAVANCAS, Isabel Siqueira. O Mundo dos Jornalistas. São Paulo: Summus 1993.

TUCÍDIDES. História da Guerra do Peloponeso. Brasília: Editora da Universidade de Brasília, 1987.

VALLADARES, Licia do Prado. A invenção da favela: do mito de origem à favela. Rio de Janeiro: FGV, 2005.

VAN DIJK, Teun. La Noticia como Discurso. Barcelona, Paidós.

VEJA. "Carta ao Leitor: o Rio de Janeiro resiste". Veja. Edição 1363, ano 27, número 43, 26/10/1994, p. 29.

VEJA. "Carta ao Leitor: falta e excesso de dados para perfis". Veja. Edição 1400, ano 28, número 28, 12/07/1995, p. 29.

VEJA. "Carta ao Leitor: novos números de um problema terrível". Veja. Edição 1411, ano 28, número 39, 27/09/1995, p. 31.

VEJA. "A Utilidade de Surpreender". Veja. Edição 2114, ano 42, número 21, 27/05/2009, p. 12-13.

VENANCIO, Rafael Duarte Oliveira. Jornalismo e Linha Editorial: construção das notícias na imprensa partidária e comercial. Rio de Janeiro: E-Papers, 2009.

VERGARA, Moema de Rezende. "'Cartas a uma senhora': questões de gênero e a divulgação do darwinismo no Brasil". Revista Estudos Feministas. Volume 15, número 02, Florianópolis, Maio-Agosto de 2007.

VERÓN, Eliseo. Construir el acontecimiento. Barcelona: Gedisa, 1995.

VEYNE, Paul. Como se Escreve a História. Lisboa: Edições 70, 1983a.

VEYNE, Paul. O inventário das diferenças. São Paulo: Brasiliense, 1983b.

VIRILIO, Paul. Velocidade e Política. São Paulo: Estação Liberdade, 1996.

VIRILIO, Paul. "O paradoxo da memória do presente na era cibernética". In CASALEGNO, Federico. Memória Cotidiana: comunidades e comunicação na era das redes. Porto Alegre: Sulina, 2006.

VOGT, Carlos. O Intervalo Semântico. São Paulo: Ateliê Editorial, Editora da Unicamp, 2009.

VOGT, Carlos. Linguagem Pragmática e Ideologia. São Paulo: Editora Hucitec, 1989.

WEINRICH, Harald. Lete: arte e crítica do esquecimento. Rio de Janeiro: Civilização Brasileira, 2001.

WHITE, Hayden. Trópicos do Discurso: ensaios sobre a crítica da cultura. São Paulo: Edusp, 1994.

WHITE, Hayden. "The modernist event". In SOBCHACK, Vivian (ed.). The Persistence of History: cinema, television and the modern event. New York: Routledge, 1996.

WHITE, Hayden. Meta-História: a imaginação histórica do século XIX. São Paulo: Edusp, 2008.

YATES, Frances Amelia. A Arte da Memória. Campinas: Editora da Unicamp, 2007.

ZANDWAIS, Ana. Estratégias de Leitura: como decodificar sentidos não-literais na linguagem verbal. Porto Alegre: Sagra, 1990.

ZELIZER, Barbie. Covering the Body: the Kennedy assassination, the media and the shaping of collective memory. Chicago: University of Chicago Press, 1992. 


\section{REPORTAGENS DO CORPUS CITADAS}

AQUINO, Ruth de. "Um castelo cafona no reino da hipocrisia". Época. São Paulo: Editora Globo, 09/02/2009, p. 106.

AQUINO, Ruth de. "O presidente Lula e o homem comum". Época. São Paulo: Editora Globo, 22/06/2009, p. 138.

AQUINO, Ruth de. "As amizades colloridas". Época. São Paulo: Editora Globo, 20/07/2009, p. 138.

AQUINO, Ruth de. "As madames e suas mucamas". Época. São Paulo: Editora Globo, 12/10/2009, p. 138.

ATHAYDE, Phydia de. "Entardecer estrelado". Carta Capital. São Paulo: Editora Confiança, 17/06/2009, p. 10-11.

ATTUCH, Leonardo. "Da Haganá ao Hamas". IstoÉ. São Paulo: Três Editorial, 14/01/2009, p. 79.

ATTUCH, Leonardo. "Pede o Boné, Tarso". IstoÉ. São Paulo: Três Editorial, 11/03/2009, p. 38.

ATTUCH, Leonardo. "O grande encontro". IstoÉ. São Paulo: Três Editorial, 22/07/2009, p. 43.

AZEVEDO, Solange. "Uma história de agressões e mortes". Época. São Paulo: Editora Globo, 13/04/2009, p. 46-52.

AZEVEDO, Solange. "A ciência e os assassinos". Época. São Paulo: Editora Globo, 14/09/2009, p. 80-82.

BARRUCHO, Luís Guilherme. "Regular é com o Brasil". Veja. São Paulo: Editora Abril, 24/06/2009, p. 108-110.

BOSCOV, Isabela. "Hora da aula". Veja. São Paulo: Editora Abril, 25/03/2009, p. 138-139.

CABRAL, Otávio. "De corpo e Alma em 2010”. Veja. São Paulo: Editora Abril, 21/01/2009, p. 62-67.

CABRAL, Otávio. "Chore por nós, Senador". Veja. São Paulo: Editora Abril, 29/04/2009, p. 66-71.

CABRAL, Otávio. "Hora de fazer a faxina”. Veja. São Paulo: Editora Abril, 01/07/2009, p. 7883.

CABRAL, Otávio. "Os novos e bons companheiros". Veja. São Paulo: Editora Abril, 22/07/2009, p. 64-66.

CABRAL, Otávio. "O passado assombra o Senado". Veja. São Paulo: Editora Abril, 12/08/2009, p. 50-58.

CABRAL, Otávio. "O Brasil é a quinta potência". Veja. São Paulo: Editora Abril, 09/09/2009, p. 64-67.

CABRAL, Otávio e ESCOSTEGUY, Diego. "Basta de folia com o dinheiro público". Veja. São Paulo: Editora Abril, 25/02/2009, p. 44-54.

CABRAL, Otávio e ESCOSTEGUY, Diego. "À sombra da Constituição". Veja. São Paulo: Editora Abril, 24/06/2009, p. 58-65.

CARTA CAPITAL. "O emprego em xeque". Carta Capital. São Paulo: Editora Confiança, 25/03/2009, p. 34-38.

CARTA CAPITAL. "Os Estados Unidos dos empreendedores". Carta Capital. São Paulo: Editora Confiança, 01/04/2009, p. 53-55.

CARTA CAPITAL. "O jabuti se move". Carta Capital. São Paulo: Editora Confiança, 27/05/2009, p. 46-48.

CARTA CAPITAL. "A velha tática do confronto". Carta Capital. São Paulo: Editora Confiança, 17/06/2009, p. 18.

CARTA CAPITAL. "Cartas Capitais - Resposta às três cartas acima". Carta Capital. São Paulo: Editora Confiança, 08/07/2009, p. 8.

CARTA CAPITAL. "Collor, Lula e uma pergunta". Carta Capital. São Paulo: Editora Confiança, 29/07/2009, p. 17. 
CARTA, Gianni. "Os donos do átomo se entendem". Carta Capital. São Paulo: Editora Confiança, 15/07/2009, p. 46-47.

CARTA, Mino. "Afrontado o Estado italiano". Carta Capital. São Paulo: Editora Confiança, 21/01/2009, p. 16.

CARTA, Mino. "Ditadura e democracia sem povo". Carta Capital. São Paulo: Editora Confiança, 11/03/2009, p. 22-23.

CARTA, Mino. "Lula e seu povo". Carta Capital. São Paulo: Editora Confiança, 27/05/2009, p. $42-45$.

CLEMENTE, Isabel e LEITÃo, Matheus. "Cara de 2010”. Época. São Paulo: Editora Globo, 19/01/2009, p. 28-31.

COLAVITTI, Fernanda. "Chegou à cama". Época. São Paulo: Editora Globo, 23/02/2009, p. $82-84$

COLAVITTI, Fernanda e MENDONÇA, Martha. "Eles se renderam à plástica". Época. São Paulo: Editora Globo, 16/11/2009, p. 116-123.

COSTA, Antônio Luiz M. C. "Rumo ao desastre". Carta Capital. São Paulo: Editora Confiança, 18/02/2009, p. 40-42.

COSTA, Antônio Luiz M. C. "O Brasil está no jogo". Carta Capital. São Paulo: Editora Confiança, 07/10/2009, p. 30-32.

COSTA, Antônio Luiz M. C. "Por que a Ira do Irã". Carta Capital. São Paulo: Editora Confiança, 25/11/2009, p. 58-61.

COSTA, Octávio. "Quando os homens da crise se reúnem”. IstoÉ. São Paulo: Três Editorial, 04/02/2009, p. 48-50.

COSTA, Octávio. "As lições de um golpe". IstoÉ. São Paulo: Três Editorial, 08/04/2009, p. 4445.

COSTA, Octávio. "Cadê a direita?". IstoÉ. São Paulo: Três Editorial, 04/11/2009, p. 54-55.

COSTA, Octávio e NICACIO, Adriana. "O PT banca a pizza". IstoÉ. São Paulo: Três Editorial, 26/08/2009, p. 36-39.

COSTA, Octávio e NICACIO, Adriana. "Chance de ouro". IstoÉ. São Paulo: Três Editorial, 09/09/2009, p. 36-41.

COSTA, Octávio, PEDROSA, Mino e PARDELlAS, Sérgio. "Por que ele ainda está aí?". IstoÉ. São Paulo: Três Editorial, 08/07/2009, p. 36-41.

COURA, Kalleo. "Nocaute a 260 por hora". Veja. São Paulo: Editora Abril, 05/08/2009, p. 118-120.

DINIZ, Laura. "O que ainda não se sabia sobre ele". Veja. São Paulo: Editora Abril, 28/01/2009, p. 54-55.

ÉPOCA. "Para enterrar o passado". Época. São Paulo: Editora Globo, 06/04/2009, p. 52-53.

ESCOSTEGUY, Diego. “Um fóssil se vai”. Veja. São Paulo: Editora Abril, 06/05/2009, p. 120.

EVELIN, Guilherme e MENDONÇA, Ricardo. "O levante do Irã". Época. São Paulo: Editora Globo, 22/06/2009, p. 92-101.

FALCÃO, David. "Avanço insuficiente”. Carta Capital. São Paulo: Editora Confiança, 21/01/2009, p. 28-29.

FERNANDES, Nelito. "Por que elas não param de crescer?". Época. São Paulo: Editora Globo, 18/05/2009, p. 54-57.

FERNANDES, Nelito. "Deu branco no humorista". Época. São Paulo: Editora Globo, 07/12/2009, p. 15-16.

FERRARI, Bruno, DEODATO, Lívia e PEREIRA, Rafael. "Um livro que não acaba". Época. São Paulo: Editora Globo, 12/10/2009, p. 96-104.

FORTES, Leandro. "A mão pesada de Corrêa". Carta Capital. São Paulo: Editora Confiança, 18/11/2009, p. 24-28.

FORTES, Leandro. "Na meia, na cueca...”. Carta Capital. São Paulo: Editora Confiança, 09/12/2009, p. 24-30.

FORTES, Leandro. "Escândalo sem fim". Carta Capital. São Paulo: Editora Confiança, $16 / 12 / 2009$, p. 28-31. 
FRUTUOSO, Suzane e MAMBRINI, Verônica. "O poder do beijo". IstoÉ. São Paulo: Três Editorial, 25/02/2009, p. 60-65.

FUCS, José. “Haverá saída sem estatizar?". Época. São Paulo: Editora Globo, 02/03/2009, p. 56-58.

FUCS, José. “As duas faces de Lula”. Época. São Paulo: Editora Globo, 21/12/2009, p. 52-60.

GRYZINSKI, Vilma. “A guerra dos quatro dias". Veja. São Paulo: Editora Abril, 07/01/2009, p. $50-59$.

GUANDALINI, Giuliano. "Bancos mal-assombrados". Veja. São Paulo: Editora Abril, 18/02/2009, p. 70-72.

GUROVITZ, Helio. "Uma decisão histórica no Supremo". Época. São Paulo: Editora Globo, 22/06/2009, p. 08.

GUROVITZ, Helio. "Um governo que confunde Estado com povo". Época. São Paulo: Editora Globo, 07/09/2009, p. 08.

GUROVITZ, Helio. "Nosso primeiro rascunho da história". Época. São Paulo: Editora Globo, 02/11/2009, p. 08.

ISTOÉ. "Outros muros que precisam cair". IstoÉ. São Paulo: Três Editorial, 21/01/2009, p. 3841.

JORDÃO, Claudia. "Foie grãs ético". IstoÉ. São Paulo: Três Editorial, 23/09/2009, p. 74.

LAGO, Rudolfo e PARDELLAS, Sérgio. "Como construir uma candidata". IstoÉ. São Paulo: Três Editorial, 21/01/2009, p. 38-41.

LEITÃO, Matheus e RAMOS, Murilo. "Na Itália, serei morto". Época. São Paulo: Editora Globo, 12/01/2009, p. 36-38.

LIRIO, Sergio. "O sal da terra". Carta Capital. São Paulo: Editora Confiança, 27/05/2009, p. 68-71.

LOES, João. "Padre e conselheiro sexual". IstoÉ. São Paulo: Três Editorial, 10/06/2009, p. 68.

LOES, João e FRUTOSO, Suzane. "Crime Universitário". IstoÉ. São Paulo: Três Editorial, 18/02/2009, p. 62-64.

MACHADO, Juliano. "O dilema de Israel”. Época. São Paulo: Editora Globo, 12/01/2009, p. 76-84.

MAGRO, Maíra. "O melhor vem depois". IstoÉ. São Paulo: Três Editorial, 22/04/2009, p. 5052.

MAIEROVITCH, Wálter Fanganiello. "Genro acredita em Battisti”. Carta Capital. São Paulo: Editora Confiança, 04/02/2009, p. 17.

MAMBRINI, Verônica. "Por que ser gentil vale a pena". IstoÉ. São Paulo: Três Editorial, 07/10/2009, p. 66-68.

MARCHIORI, Rodrigo. "Por que os corruptos não são punidos no Brasil?". Época. São Paulo: Editora Globo, 23/03/2009, p. 42-43.

MARQUES, Carlos José. "Perseguições, penas e crimes". IstoÉ. São Paulo: Três Editorial, 01/04/2009, p. 20.

MEIRELES, Andrei e LEITÃo, Matheus. "Ele usou a ex-babá como laranja". Época. São Paulo: Editora Globo, 27/04/2009, p. 54-57.

MENEZES, Cynara. "Cesare: veni, vidi, vici”. Carta Capital. São Paulo: Editora Confiança, 21/01/2009, p. 34-36.

MENEZES, Cynara. "Renasce o centrão". Carta Capital. São Paulo: Editora Confiança, 11/02/2009, p. 22-27.

MENEZES, Cynara. "O dono do Senado". Carta Capital. São Paulo: Editora Confiança, 08/04/2009, p. 22-27.

MENEZES, Cynara. "O golpe golpeado". Carta Capital. São Paulo: Editora Confiança, 07/10/2009, p. 26-29.

MENEZES, Cynara e FORTES, Leandro. "Barbosa reage". Carta Capital. São Paulo: Editora Confiança, 29/04/2009, p. 20-24.

MOHERDAUI, Bel. "Elas não passam em branco". Veja. São Paulo: Editora Abril, 14/10/2009, p. 128-129. 
NEPOMUCENO, Eric. "Restam as palavras". Carta Capital. São Paulo: Editora Confiança, 19/08/2009, p. 26-29.

NEPOMUCENO, Eric. “A soja resiste, mas e a vida humana?". Carta Capital. São Paulo: Editora Confiança, 02/09/2009, p. 62-63.

NÓBREGA, Maílson da. "O terceiro mandato arruinaria a economia". Veja. São Paulo: Editora Abril, 17/06/2009, p. 93.

NOGUEIRA, Paulo. “Endzeitstimmung”. Época. São Paulo: Editora Globo, 09/02/2009, p. 7274.

NOGUEIRA, Paulo. “O topless na França? C'est fini”. Época. São Paulo: Editora Globo, 27/07/2009, p. 98.

OLTRAMARI, Alexandre. "O dia de índio de Joaquim Barbosa". Veja. São Paulo: Editora Abril, 29/04/2009, p. 78-79.

PARDELLAS, Sérgio. "Oposição desde criancinha". IstoÉ. São Paulo: Três Editorial, 18/02/2009, p. 50-52.

PARDELLAS, Sérgio. "Quércia faz o PMDB de Serra". IstoÉ. São Paulo: Três Editorial, 27/05/2009, p. 44-46.

PATI, Camila e MARQUES, Hugo. "Calote oficial". IstoÉ. São Paulo: Três Editorial, 17/06/2009, p. 48-49.

PATI, Camila e MARQUES, Hugo. "Diploma decorativo". IstoÉ. São Paulo: Três Editorial, 24/06/2009, p. 80.

PEREIRA, Camila. "Uma segunda opinião". Veja. São Paulo: Editora Abril, 04/03/2009, p. 66-73.

PETRY, André. "Por que os EUA não deixam a AIG quebrar". Veja. São Paulo: Editora Abril, 11/03/2009, p. 98-99.

RAMOS, Murilo. "Prepare-se. Vão mexer na poupança". Época. São Paulo: Editora Globo, 23/03/2009, p. 48-50.

RIBEIRO, Gustavo. "UNE chapa-branca". Veja. São Paulo: Editora Abril, 29/07/2009, p. 76.

RODRIGUES, Alan. "Como Lula driblou o destino". IstoÉ. São Paulo: Três Editorial, 13/05/2009, p. 36-39.

ROUBINI, Nouriel. "O mercado de trabalho americano". Carta Capital. São Paulo: Editora Confiança, 19/08/2009, p. 61.

SANCHES, Mariana. "Prosa, poesia e política". Época. São Paulo: Editora Globo, 10/08/2009, p. 62-64.

SEGATTO, Cristiane. "Um dia na fábrica de células-tronco". Época. São Paulo: Editora Globo, 23/03/2009, p. 84-87.

SOARES, Ronaldo. "A favela no limite". Veja. São Paulo: Editora Abril, 22/04/2009, p. 66-68. SÓCRATES. "O vício do salto alto". Carta Capital. São Paulo: Editora Confiança, 11/03/2009, p. 62 .

SUASSUNA, Luciano. “Quando o Congresso dava resultado". IstoÉ. São Paulo: Três Editorial, 29/04/2009, p. 45-46.

SUASSUNA, Luciano. "O peso de uma condenação". IstoÉ. São Paulo: Três Editorial, 01/04/2009, p. 76-81.

TEIXEIRA, Duda. "Um atleta além dos limites". Veja. São Paulo: Editora Abril, 26/08/2009, p. 98-99.

TOLEDO, Roberto Pompeu de. "A reinvenção do rei". Veja. São Paulo: Editora Abril, 28/01/2009, p. 110.

TUMA, Rogério. "Para quem o médico trabalha?". Carta Capital. São Paulo: Editora Confiança, 02/12/2009, p. 66.

VEJA. "Tarso pode estar certo". Veja. São Paulo: Editora Abril, 21/01/2009, p. 10-11.

VEJA. “Obrigado, Tarso Genro". Veja. São Paulo: Editora Abril, 21/01/2009, p. 73.

VEJA. "Jarbas conta tudo". Veja. São Paulo: Editora Abril, 18/02/2009, p. 12-13.

VEJA. "Qualidade sem diploma". Veja. São Paulo: Editora Abril, 24/06/2009, p. 12-13.

VEJA. "Más notícias, presidente". Veja. São Paulo: Editora Abril, 04/11/2009, p. 100. 
VEJA. "Quando o sucesso é quase uma lei". Veja. São Paulo: Editora Abril, 11/11/2009, p. 180-182.

VENTUROLI, Thereza. "O artista que recria o passado". Veja. São Paulo: Editora Abril, 23/09/2009, p. 128-130.

VERA, Andres. "A nova onda dos remédios para o cérebro". Época. São Paulo: Editora Globo, 11/05/2009, p. 64-69.

VILLAMÉA, Luiza. "O massacre de gaza”. IstoÉ. São Paulo: Três Editorial, 14/01/2009, p. 70-79.

VILLAMÉA, Luiza. "Um golpe fora de época". IstoÉ. São Paulo: Três Editorial, 08/07/2009, p. 100-101.

WOOD JR., Thomaz. "Empregos vitalícios". Carta Capital. São Paulo: Editora Confiança, 28/01/2009, p. 25. 